Florida International University FIU Digital Commons

4-18-2016

\title{
The Pneuma Network: Transnational Pentecostal Print Culture In The United States And South Africa, 1906-1948
}

Lindsey Brooke Maxwell

Florida International University, lindseymaxwell.fiu@gmail.com

DOI: $10.25148 /$ etd.FIDC000711

Follow this and additional works at: https://digitalcommons.fiu.edu/etd

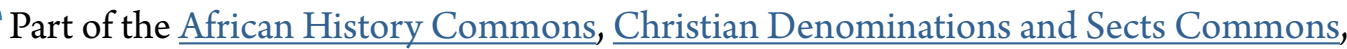
Christianity Commons, History of Christianity Commons, History of Religion Commons, Missions and World Christianity Commons, New Religious Movements Commons, and the United States History Commons

\section{Recommended Citation}

Maxwell, Lindsey Brooke, "The Pneuma Network: Transnational Pentecostal Print Culture In The United States And South Africa, 1906-1948" (2016). FIU Electronic Theses and Dissertations. 2614.

https://digitalcommons.fiu.edu/etd/2614

This work is brought to you for free and open access by the University Graduate School at FIU Digital Commons. It has been accepted for inclusion in FIU Electronic Theses and Dissertations by an authorized administrator of FIU Digital Commons. For more information, please contact dcc@fiu.edu. 


\title{
FLORIDA INTERNATIONAL UNIVERSITY
}

\author{
Miami, Florida
}

THE PNEUMA NETWORK: TRANSNATIONAL PENTECOSTAL PRINT

CULTURE IN THE UNITED STATES AND SOUTH AFRICA, 1906-1948

A dissertation submitted in partial fulfillment of

the requirements for the degree of

DOCTOR OF PHILOSOPHY

in

HISTORY

by

Lindsey Brooke Maxwell 
To: Dean John F. Stack, Jr.

College of Arts, Sciences and Education

This dissertation, written by Lindsey Brooke Maxwell, and entitled The Pneuma Network: Transnational Pentecostal Print Culture in the United States and South Africa, 1906-1948, having been approved in respect to style and intellectual content, is referred to you for judgment.

We have read this dissertation and recommend that it be approved.

Kirsten Wood

Aurora Morcillo

Hilary Jones

Erik Larson

Darden Asbury Pyron, Major Professor

Date of Defense: April 18, 2016

The dissertation of Lindsey Brooke Maxwell is approved.

Dean John F. Stack, Jr.
College of Arts, Sciences and Education

College of Arts, Sciences and Education

Andrés G. Gil

Vice President for Research and Economic Development and Dean of the University Graduate School

Florida International University, 2016 
(C) Copyright 2016 by Lindsey Brooke Maxwell

All rights reserved. 


\section{ACKNOWLEDGMENTS}

A great number of people and institutions deserve thanks for aiding me towards the completion of this project. I would like to express deepest gratitude to my advisor Dr. Darden Asbury Pyron for his guidance, advice, and encouragement during my candidacy. I must also thank my dissertation committee of Dr. Kirsten Wood, Dr. Aurora Morcillo, Dr. Hillary Jones, and Dr. Erik Larson for their feedback and support these past few years as I moved from an idea to a completed study. I owe many thanks to Dr. Alex Lichtenstein for introducing me to this rich field, and for his advice on all topics related to South Africa. I would also like to give a special thanks to Dr. Katherine Osborn, who advised me as an undergrad and helped steady me on the path towards fulfilling a dream.

Several institutions and centers provided me financial support for this project during the research and writing. This dissertation was funded by several grants from Florida International University, including the Dissertation Evidence Acquisition Fellowship and the Dissertation Year Fellowship. The FIU Graduate and Professional Student Committee and College of Arts and Sciences and the Morris and Anita Broad Fellowship also financially supported the archival research for this project. Furthermore, this research project would not have been possible without the friendly assistance and advice from the staff at the David Du Plessis archives at Fuller Theological Seminary, the Schomburg Center for Research in Black Culture, the Flower Pentecostal Heritage Center archives, and 
especially the Auckland Park Theological Seminary Apostolic Faith Mission archives.

This journey would not have been possible without the support from my family, friends, professors, and mentors. To my professors, thank you for your teaching, advice, and support. To my friends, thank you for your encouragement. To my family, thank you for keeping me grounded. To my parents, thank you for instilling in me a drive to question, challenge, and persevere in everything I do. Finally, I owe an enormous amount of gratitude to my partner, Sven, for his love, support, patience, and encouragement during the various stages of this Ph.D. adventure. Thank you. 


\title{
ABSTRACT OF THE DISSERTATION
}

THE PNEUMA NETWORK: TRANSNATIONAL PENTECOSTAL PRINT

CULTURE IN THE UNITED STATES AND SOUTH AFRICA, 1906-1948

by

\author{
Lindsey Brooke Maxwell
}

Florida International University, 2016

Miami, Florida

Professor Darden Asbury Pyron, Major Professor

Exploding on the American scene in 1906, Pentecostalism became arguably the most influential religious phenomenon of the twentieth century. Sparked by the Azusa Street Revival in Los Angeles, the movement grew rapidly throughout the United States and garnered global momentum. This study investigates the original Los Angeles Apostolic Faith Mission and the subsequent extension of the mission to South Africa through an examination of periodicals, mission records, and personal documents. Using the Apostolic Faith Mission of South Africa as a case study, this study measures the significance of print media in the emergence and evolution of the early Pentecostal movement.

Based on historical analysis of more than 260 issues of the mission's periodical, "The Comforter and Messenger of Hope," this dissertation demonstrates how the publication served a variety of functions critical to the establishment of Pentecostalism in South Africa. As a work of cultural history, it situates the periodical within larger trends in South African culture and society. It illustrates how the periodical functioned simultaneously at the local and 
international level to standardize Pentecostal discourse and formulate an early Pentecostal identity. Finally, this dissertation argues that Pentecostal periodicals formed a transnational network of Pentecostal thought, connections, and support in the early twentieth century that influenced the development of Pentecostalism in the South African context. 
CHAPTER

PAGE

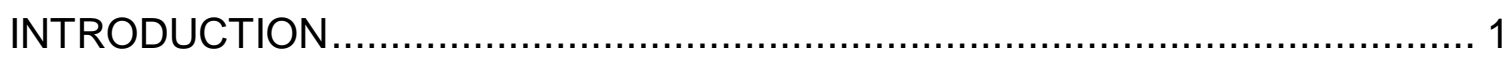

CHAPTER 1: TURBULENT BEGINNINGS: ROOTS OF PENTECOSTALISM 1880s - 1906

CHAPTER 2: A MODERN PENTECOST: AZUSA STREET AND THE BIRTH OF THE PENTECOSTAL MOVEMENT.

CHAPTER 3: THE APOSTOLIC FAITH AND TRANSNATIONAL PENTECOSTAL PRINT CULTURE

CHAPTER 4: HERALDS OF NEW LIGHT: THE FIRE FALLS ON JOHANNESBURG 156

CHAPTER 5: THE COMFORTER AND MESSENGER OF HOPE 198

CHAPTER 6: THE UNLIMITED COMPANY: THE APOSTOLIC FAITH MISSION AS EVANGELICAL BUSINESS, 1913-1928

CHAPTER 7: THE PNEUMA NETWORK: 1930s - 1948 262

CHAPTER 8: EPILOGUE .294

BIBLIOGRAPHY .299

VITA 342 


\section{INTRODUCTION}

Exploding on the American scene in 1906, Pentecostalism became the most important mass religious movement of the twentieth century. ${ }^{1}$ Sparked by the Azusa Street Revival in Los Angeles, the phenomenon spread rapidly throughout the United States and within a decade Pentecostal congregations could be found around the world. This study investigates the original Los Angeles Apostolic Faith Mission and the subsequent extension of the mission to South Africa. Currently at 1.4 million members, the Apostolic Faith Mission of South Africa is the largest Pentecostal denominational church in the country, yet it remains an understudied chapter in the history of Pentecostalism. ${ }^{2}$ Historians point to many factors as the cause of the global rise of Pentecostalism in the twentieth century. This dissertation examines one element that has been overlooked: their use of print media in establishing, maintaining, and building a Pentecostal identity. The focus of this project centers on how the Apostolic Faith Mission of South Africa utilized the medium of print to establish a new brand of faith in the South African context. It focuses primarily on Pentecostals' use of periodicals to network, communicate, collaborate, and evangelize. It argues that

\footnotetext{
${ }^{1}$ See James Goff, Fields White Unto Harvest: Charles F. Parham and the Missionary Origins of Pentecostalism. (Fayetteville: University of Arkansas Press, 1988), 3; and Henry P Van Dusen, "The Third Force in Christendom: Gospel-Singing, Doomsday-Preaching Sects Emerge as a Mighty Movement in World Religion" LIFE. June $9^{\text {th }}, 1958,113$.

${ }^{2}$ Isak Burger, "The Apostolic Faith Mission of South Africa: An Introduction," http://www.afmags.org/introduction. Accessed April 1 ${ }^{\text {st }}, 2016$.
} 
Pentecostal periodicals formed a transnational 'pneuma network' of Pentecostal thought, connections, and support in the early twentieth century that influenced the development of Pentecostal identity in the South African context.

The rise of Pentecostalism profoundly impacted worldwide Christianity. In 2012, the Pew Research Forum published the results of a multi-country survey of religion. The survey confirmed that Pentecostalism continues to be the fastest growing segment of Christianity worldwide. The study estimated the number of classical Pentecostals ${ }^{3}$ amounts to nearly 280 million while charismatic Christians ${ }^{4}$ number 305 million adherents worldwide. ${ }^{5}$ Taken together, Pentecostals and charismatics accounted for approximately 8.5 percent of the total world population and 26.7 percent of the worldwide Christian population in $2011 .{ }^{6}$ Indeed, while the twentieth century has seen the general decline of

\footnotetext{
${ }^{3}$ Classical Pentecostalism refers to the institutionalized Pentecostal denominations that emerged from the Wesleyan-Holiness traditions of the late nineteenth century and the Topeka and Azusa events of the early twentieth century. Examples of these churches include the Assemblies of God, the Church of God in Christ (COGIC), the Church of God (Cleveland), and the Foursquare Gospel.

4 "Charismatic" is an umbrella term that refers to the use of spiritual gifts. The charismatic movement is diffuse and even more difficult to categorize, as it typically plays a small role in traditionally Protestant and Catholic churches. This term, coined in 1962 by American Lutheran minister Harald Bredesen, refers to churches that believe that the manifestations of the Holy Spirit, as described in the book of Acts and characteristic of the first century Christian church, are still available to Christians today. This term includes Pentecostals, but not all Charismatics consider themselves Pentecostal.

${ }^{5}$ Pew Forum on Religion \& Public Life, and Pew Research Center. Global Christianity: a report on the size and distribution of the world's Christian population. (Washington, D.C.: Pew Research Center, 2011). http://www.pewforum.org/Christian/Global-Christianity-exec.aspx, accessed January $4^{\text {th }}, 2016$.

${ }^{6}$ The Pew Forum defines charismatics and Pentecostals as mutually exclusive groups, however there is certainly overlap between the groups. Pentecostals are those who belong to a classical Pentecostal denomination, while charismatics are defined as those who are influenced by Pentecostalism and adhere to charismatic beliefs but do not belong to one of the classical Pentecostal denominations. As defined, "Pentecostals" comprise 4 percent of world population and 12.8 percent of Christian population. See: Pew Forum on Religion \& Public Life, and Pew
} 
mainline Protestant church membership, Pentecostal and charismatic churches continue to out-pace expectations, particularly in the southern hemisphere. Numerically, they are second only to Roman Catholics, comprising over onequarter of the world's Christians, and are the dominant Christian groups in many countries in Africa and Latin America.

Pentecostalism expanded rapidly to prominence in both the United States and South Africa over the course of the twentieth century, encompassing many distinct denominations and spawning a charismatic movement that influenced mainline Protestant churches as well as the Catholic Church. Their influence in music, expression, ecclesiastics, and evangelicalism cannot be overstated. ${ }^{7}$ South Africa was one of the first countries to which missionaries left after having visiting the initial 1906 Azusa Street revival in Los Angeles California. The initial group founded the Apostolic Faith Mission of South Africa in 1908, and the AFM is currently the largest Pentecostal denomination in the country, with over 1.4

Research Center. Global Christianity: a report on the size and distribution of the world's Christian population, 17.

${ }^{7}$ See Harvey Cox, Fire From Heaven: The Rise of Pentecostal Spirituality and the Reshaping of Religion in the Twenty-first Century. (Cambridge, MA: Da Capo Press, 1995); Allen H. Anderson, To the Ends of the Earth: Pentecostalism and the Transformation of World Christianity, (New York, NY: Oxford University Press, 2013); Jack W. Hayford, and S. David Moore, The Charismatic Century: The Enduring Impact of the Azusa Street Revival, (New York, NY: Time Warner Books Group, 2006); Donald E. Miller, Kimon Howland Sargeant, and Richard W. Flory. Spirit and Power: The Growth and Global Impact of Pentecostalism. (New York, NY: Oxford University Press, 2013); Edward O'Connor, The Pentecostal Movement in the Catholic Church. (Norte Dame, IN: Ave Maria Press, 1971); Vinson Synan, The Twentieth-Century Pentecostal Explosion: the Exciting Growth of Pentecostal Churches and Charismatic Renewal Movements. (Altamonte Springs, Fla., Creation House, 1987); and Tona J. Hangen, Redeeming the Dial: Radio, Religion, and Popular Culture in America. (Chapel Hill: University of North Carolina Press, 2002). 
million adherents. ${ }^{8}$ The group is one of many African Pentecostal groups that has helped recast worldwide Christianity in the twentieth century. Despite these numbers and impact, Pentecostals are still routinely excluded from the general framework of twentieth-century American history, and are relatively silent in works on South African history as well.

Nonetheless, South Africa provides an outstanding context for telling this dramatic story of the early Pentecostal movement. Pentecostal missionaries settled in South Africa in 1908, making it one of the first countries to hear directly from those who had been at the Azusa Street Revival. These Pentecostals founded the Apostolic Faith Mission, which remains the oldest and largest Pentecostal denomination in the country. Scholars have frequently used the country as a comparison point to the US in studies of race, culture, religion, and politics. ${ }^{9}$ The US and South Africa share many similarities that make a project on religious history in particular quite fruitful. In the US and South Africa, the cultural

\footnotetext{
${ }^{8}$ Isak Burger, "The Apostolic Faith Mission of South Africa: An Introduction," http://www.afmags.org/introduction, accessed April 1 ${ }^{\text {st }}, 2016$.

${ }^{9}$ See: Anthony W. Marx, Making Race and Nation: A Comparison of South Africa, the United States, and Brazil (Cambridge, U.K: Cambridge University Press, 1998); James T.

Campbell, Songs of Zion: The African Methodist Episcopal Church in the United States and South Africa (Chapel Hill: University of North Carolina Press, 1998); George M. Fredrickson, Black Liberation: A Comparative History of Black Ideologies in the United States and South Africa (New York: Oxford University Press, 1996); Olga Barrios, The Black Theatre Movement in the United States and in South Africa (València: Universitat de València, 2008); George M. Fredrickson, White Supremacy: A Comparative Study in American and South African History (New York: Oxford University Press, 1981); Robert T. Vinson, The Americans Are Coming!: Dreams of African American Liberation in Segregationist South Africa (Athens, Ohio: Ohio University Press, 2011); Pamela E. Brooks, Boycotts, Buses, and Passes: Black Women's Resistance in the U.S. South and South Africa (Amherst: University of Massachusetts Press, 2008); Ivan T. Evans, Cultures of Violence: Racial Violence and the Origins of Segregation in South Africa and the American South (Manchester, UK: Manchester University Press, 2011); and Martin Hall, Archaeology and the Modern World: Colonial Transcripts in South Africa and the Chesapeake (London: Routledge, 2000).
} 
and social landscapes are decidedly marked by the influence of Christian theology, language, and practice. ${ }^{10}$ Both countries were profoundly influenced by early groups that held to strict Calvinist doctrines of predestination and providence. Church leaders in both countries used Christian doctrine to both support and oppose racial segregation and slavery. ${ }^{11}$ During the struggle over civil rights for blacks and other minorities in each country, protesters on both sides employed Christian imagery, biblical texts, affirmations, and symbols to justify their stance. Furthermore, both countries experienced a period of sustained revivals in the nineteenth century, and devastating wars that had a profound impact on the religious groups in each setting that set the stage for the advent of Pentecostalism. Finally, the Pentecostals that settled in South Africa replicated the use of periodicals as an effective and efficient means of mass communication and evangelization, thereby launching the movement in the country while connecting it to the larger movement worldwide.

The history of the Apostolic Faith Mission suggests that Pentecostals, more than any other Christian group of the 20th century, successfully adapted the sacred to the modern in their use of the periodical. Employing modern

\footnotetext{
${ }^{10}$ See Richard Elphick and T. R. H. Davenport. Christianity in South Africa: A Political, Social, and Cultural History. (Berkeley, Calif: University of California Press, 1997); John W. De Gruchy, The Church Struggle in South Africa. (Grand Rapids: W.B. Eerdmans Pub. Co, 1979); Mark A. Noll, America's God: From Jonathan Edwards to Abraham Lincoln. (Oxford: Oxford University Press, 2002); Sydney E. Ahlstrom, A Religious History of the American People. (New Haven: Yale University Press, 1972).

${ }^{11}$ Two excellent examples of this issue are David L. Chappell, A Stone of Hope: Prophetic Religion and the Death of Jim Crow. (Chapel Hill: University of North Carolina Press, 2004), and Daniel R. Magaziner, The Law and the Prophets: Black Consciousness in South Africa, 19681977, (Athens: Ohio University Press, 2010).
} 
business and marketing techniques in their evangelical efforts, and preaching a message of spiritual renewal and individual agency, they embodied the transformations of the era. Pentecostal periodicals around the world transmitted secular and sacred news and ideas through what I term a 'pneuma network' of print which influenced local Pentecostal identities. Unbound by traditional ties, they promoted innovation and variation in their evangelical efforts. They embraced science and technology when it suited the goal of evangelization. Their use of mass media for proselytizing and communicating marked a turning point in the modernization of American evangelicalism. Their central message of "freedom in the Spirit" was radical for its time. Despite their relatively late arrival to the scene of the crowded religious landscapes of the United States and South Africa, Pentecostals thrived by offering people modern and empowering ways to understand the supernatural and themselves as spiritual agents of God, as well as a home in a worldwide community of believers.

This study builds upon a foundation comprised of the long historiography of Christianity in South Africa and the more recent historiography of Pentecostalism within the United States. It also adds to the growing scholarship on the relationship between African and American Christianity, and particularly the role of print in fostering transatlantic religious networks. It also draws on various other bodies of historiographical research, including the Atlantic, Pentecostalism, periodical studies, and US and South Africa cultural history.

Pentecostalism has intrigued religious scholars for many decades, primarily in the social science disciplines. In 1958 LIFE Magazine became the 
first major publication to recognize the growing Pentecostal movement, declaring it the "Third Force in Christendom." ${ }^{2}$ Since then, scholars have attempted to understand and explain the rise of this mass global religious movement. The sheer size of the Pentecostal-Charismatic movement is problematic and unsympathetic to synthesis, which may help to explain why the field has long been dominated by theologians. The history of the Pentecostal movement in the United States remained understudied by academic historians until the early 1970s. During the 1970s it became apparent that the Pentecostal movement was not simply another sect of Christianity, but was rather a rapidly spreading religious movement that was seeing enormous growth around the globe. Furthermore, the Society for Pentecostal Studies was established in 1970, bringing together a number of biblical Pentecostal scholars in the US who sought to "stimulate, encourage, recognize, and publicize the work of Pentecostal and charismatic scholars; to study the implications of Pentecostal theology in relation to other academic disciplines, seeking a Pentecostal world-and-life view; and to support fully, to the extent appropriate for an academic society, the statement of purposes of the World Pentecostal Fellowship." ${ }^{13}$ This scholarly association not only encouraged the study of Pentecostalism from within, but also had the effect of raising further awareness of the religious movement amongst academic historians as well. Since then, the historiography of the Pentecostal movement in

\footnotetext{
12 Dusen, "The Third Force in Christendom," 113.

${ }^{13}$ Society for Pentecostal Studies, "Who We Are," http://www.sps-usa.org/\#/home/who-we-are, accessed Jan 4, 2016.
} 
America has grown from the early histories of individual churches and biographies of individuals within the Pentecostal movement to the more recent recognition of the influence of this particular religious movement within the larger context of US social history.

One of the longest-running debates within the field continues to be that of origin. Scholars disagree on the founder(s) of the movement, but generally agree that Charles Parham and William Seymour are two key individuals, giving credit to Parham for the theological foundations and Seymour for the evangelical emphasis of the movement. ${ }^{14}$ More recent works explore the role of black women in the original prayer meetings that started the Azusa Street Revival, thereby reasserting their importance in the movement. ${ }^{15}$ Biographies have been particularly useful for helping to shed light on the beliefs and motivations of some of the early Pentecostal leaders. ${ }^{16}$ This focus on the origins and theological development of the movement has left some significant gaps in our

\footnotetext{
${ }^{14}$ James R. Goff provided a detailed defense of Parham's critical role in the movement in his 1988 work, Fields White Unto Harvest: Charles F. Parham and the Missionary Origins of Pentecostalism. (Fayetteville: University of Arkansas Press, 1988). A more recent work by Gaston Espinosa examines Seymour's role in the Azusa Street Revival as the originator of the movement globally. See Gastón Espinosa, William J. Seymour and the Origins of Global Pentecostalism: A Biography and Documentary History. (Durham and London: Duke University Press, 2014).

${ }^{15}$ See Valarie Cooper, "Laying the Foundations of Azusa: Black Women and Public Ministry in the Nineteenth Century," in Yong, Amos, and Estrelda Y. Alexander, eds. Afro-Pentecostalism: Black Pentecostal and Charismatic Christianity in History and Culture. (New York: NYU Press, 2012); Cheryl J. Sanders, Saints in Exile: The Holiness-Pentecostal Experience in African American Religion and Culture. (New York: Oxford University Press, 1999).

${ }^{16}$ James R. Goff and Grant Wacker, Portraits of a Generation: Early Pentecostal Leaders. (Fayetteville: University of Arkansas Press, 2002); Chas H. Barfoot, Aimee Semple Mcpherson and the Making of Modern Pentecostalism, 1890-1926 (London: Equinox, 2011); Joshua R. Ziefle, David Du Plessis and the Assemblies of God: The Struggle for the Soul of a Movement. (Leiden: Brill, 2013).
} 
understanding of the individuals involved and the means by which they carried out their mission. This project is in part an attempt to fill those lacunae.

Although one could split Pentecostals into dozens of categories, Augustus Cerillo has identified four main avenues of interpretation in the historiography: providential, genetic, multicultural, and functional. ${ }^{17}$ The earliest works on Pentecostalism were written by those within the movement, and therefore tend to take a providential position. These works tended to attribute the origin and growth of the movement to a providential God rather than human or natural causes. ${ }^{18}$ This branch of the historiography continues to thrive today through various Christian publishing agencies. While this scholarship tends to be quite apologetic and ahistorical, it provides insight into how Pentecostals themselves understand and preserve their history. ${ }^{19}$

Beginning in the 1970s, the next phase of scholarship focused on the theological roots of Pentecostalism. During this period many of the currently renowned historians were working on their doctorates in this field of Pentecostal history. ${ }^{20}$ This wave of scholarship attempted to connect Pentecostalism with

\footnotetext{
${ }_{17}$ Augustus Cerillo, "The Origins of American Pentecostalism". Pneuma. 15, no. 1 (1993): 77-88.

${ }^{18}$ See Bennett Freeman Lawrence, The Apostolic Faith Restored. (St. Louis, Mo: Gospel Pub. House, 1916); Carl Brumback, Suddenly ... From Heaven: a History of the Assemblies of God. (Springfield, Mo: Gospel Pub. House, 1961); James L. Tyson, The Early Pentecostal Revival: History of Twentieth-Century Pentecostals and the Pentecostal Assemblies of the World, 1901-30 (Hazelwood, Mo: Word Aflame Press, 1992).

${ }^{19}$ See: Rufus G. W. Sanders, William Joseph Seymour: Black Father of the Twentieth Century Pentecostal/charismatic Movement. (Sandusky, Ohio: Alexandria Publications, 2001); Larry E. Martin, The Life and Ministry of William J. Seymour: And a History of the Azusa Street Revival. (Joplin, MO: Christian Life Books, 1999).

${ }^{20}$ Cerillo, "The Origins of American Pentecostalism," 78.
} 
larger religious traditions. Walter J. Hollenweger's The Pentecostals: the Charismatic Movement in the Churches, (1972) and Vinson Synan's The Holiness-Pentecostal Movement in the United States (1971) were some of the first attempts to account for the rapid rise and spread of Pentecostalism in a historical perspective, and focused on the societal and doctrinal origins of the movement. Hollenweger, a Swiss theologian, had been raised in the Pentecostal tradition (although he later left his Pentecostal church for a reformed Presbyterian church), and had his ten volume doctoral dissertation Handbuch der Pfingstbewegung (Handbook of the Pentecostal Movement) published in 1966. Considered an expert on the Pentecostal movement, Hollenweger's book The Pentecostals sought to trace the movement from its Azusa street origin which he viewed as "a revival amongst the negroes of North America at the beginning of the present century." 21 Vinson Synan's The Holiness-Pentecostal Tradition was a pioneering work that broadly outlined the "second blessing" tradition, ${ }^{22}$ tracing it from the eighteenth century Catholic and Anglican mystics, through Wesleyism, the Holiness movement of the 19th century, and finally the emergence of modern Pentecostalism. ${ }^{23}$ Disposing of the theological jargon of Hollenweger, Synan described the basic Pentecostal theological belief system as "Armenian,

\footnotetext{
${ }^{21}$ Walter J. Hollenweger, 1972. The Pentecostals; the Charismatic Movement in the Churches. (Minneapolis: Augsburg Pub. House), xvii.

${ }^{22}$ Also known as Baptism with the Holy Spirit, or Holy Ghost Baptism. Some groups associate this with spiritual gifts.

${ }^{23}$ Vinson Synan, The Holiness-Pentecostal Tradition: Charismatic Movements in the Twentieth Century. (Grand Rapids, Mich: W.B. Eerdmans Pub. Co, 1971).
} 
perfectionistic, premillennial, and charismatic."24 The centrality of Methodism within the Pentecostal tradition was central to Synan's overall argument that Pentecostalism was a conservative reform movement that broke with the Methodist church in 1894 because holiness adherents objected to the growing acceptance of the Social Gospel within the Methodist church. Synan concluded that "basically, the Pentecostal and holiness churches are attempting to propagate the historic message of Methodism." 25 Thus in Synan's analysis the holiness-Pentecostal adherents considered themselves the "true" followers of Wesleyan Methodism. Edith Blumhofer meanwhile argues instead that Pentecostalism emerged out of the Reformed Keswick tradition. ${ }^{26}$ Donald Dayton takes the middle road and argues that both streams fed into the same river, with Pentecostalism emerging as a result of both influences. ${ }^{27}$

The question of origin surrounds the disagreement over whether scholars should view the Topeka and/or Azusa revivals of the early twentieth century as the origin point of the movement, or whether slightly earlier revivals in Britain, India, and Korea should be understood as site of origin as well. Some scholars have attempted to reorient the focus and locate the origin in the non-Western world. ${ }^{28}$ They argue that Pentecostalism was not solely American in origin, but

\footnotetext{
${ }^{24}$ Synan, The Holiness-Pentecostal Movement in the United States, 217. 25 lbid.

${ }^{26}$ Also known as the Higher Life Movement, a movement devoted to Christian Holiness in England.

${ }^{27}$ Donald W. Dayton, Theological Roots of Pentecostalism. (West Peabody, Mass: Hendrickson, 1987).

${ }^{28} \mathrm{Joe}$ Creech, Michael Bergunder, and Allan Anderson are some of the foremost critics of the
} 
arose out of a long theological trajectory of Wesleyan pietism and global revivalism. This has primarily been seen as an attempt to emphasize the nonWestern character of the movement. ${ }^{29}$ Pointing to pre-twentieth century Pentecostal-like revivals, these scholars claim it has been a truly global movement from the beginning, having emerged from a series of revivalist and pietistic movements that occurred around the globe during the nineteenth century, and drew from various strains of theology. ${ }^{30}$

This global origin viewpoint has several implications that are problematic. Locating the origin of the Pentecostal movement in a vague global nebula of revivals implies that there was somehow a vast unseen network of pastors, missionaries, and believers who in tandem began a global renewalist revival movement, somehow coalescing into a coherent Pentecostal movement by the early twentieth century. ${ }^{31}$ First, it ignores the agency of individuals in the movement, and their motivations, beliefs, and actions. The characters of the

\footnotetext{
"Azusa origin" perspective and instead promote a multi-origin argument. See Joe Creech, "Visions of Glory: The Place of the Azusa Street Revival in Pentecostal History," Church History 65 (1996), 405-424; Michael Bergunder, The South Indian Pentecostal Movement in the Twentieth Century. (Grand Rapids, MI: William B. Eerdmans Pub. Co, 2008); and Allan Anderson, Spreading Fires: The Missionary Nature of Early Pentecostalism. (Maryknoll, N.Y.: Orbis Books, 2007).

${ }^{29}$ Everett A Wilson, “They Crossed the Red Sea, Didn't They? Critical History and Pentecostal Beginnings" in Murray W. Dempster, Byron D. Klaus \& Douglas Petersen, Eds., The Globalization of Pentecostalism: A Religion Made to Travel (Oxford: Regnum, 1999), 109-110.

${ }^{30}$ Allan Anderson is one of the most prolific writers on the subject of global, and particularly, nonwestern Pentecostalism as well as one of the most ardent supporters of a global origins thesis. See Anderson, Allan. An Introduction to Pentecostalism: Global Charismatic Christianity. (Cambridge, U.K: Cambridge University Press, 2004) and Allan Anderson, To the Ends of the Earth: Pentecostalism and the Transformation of World Christianity, (New York: Oxford University Press, 2013).

${ }^{31}$ Espinosa, William J. Seymour and the Origins of Global Pentecostalism, 22-23.
} 
movement therefore become second to the movement itself. Second, it overlooks the mechanisms involved in growing and sustaining such a mass religious movement. This is odd, as Pentecostals themselves often boasted about their ability to utilize mass media and technology, and emphasize their lack of traditional means of evangelism. Third, it ironically overlooks the central complexity of race in the movement, and in particular the central role of William Seymour and the African American women at the heart of Azusa Street. Finally, it does not take into account local social, political, and cultural contexts that influenced the adaptation of the movement.

The 1980s saw increasing interest of historians into the role of African Americans, Hispanics, and women in Pentecostal history. The multicultural perspective that emerged attempted to right these gaps in the historiography. ${ }^{32}$ Since then others in this group have sought to re-emphasize the primacy of William Seymour over that of Charles Parham, and the Azusa Street revival over that of Topeka Kansas, in the history of the movement. They also underscore the interracial nature of the Azusa Street revival and argue that racial reconciliation is at the core of Pentecostal theology. lain MacRobert's The Black Roots and White Racism of Early Pentecostalism in the USA provided an analysis of the African

\footnotetext{
32 David D. Daniels, "Dialogue Between Black and Hispanic Pentecostal Scholars: A Report and Some Personal Reflections". Pneuma. 17, no. 1 (1995): 219-228; Gastón Espinosa, Borderland Religion: Los Angeles and the Origins of the Latino Pentecostal Movement in the U.S., Mexico, and Puerto Rico, 1900-1945. (Ph. D. University of California, Santa Barbara, 1999); Scott Billingsley, It's a New Day: Race and Gender in the Modern Charismatic Movement. (Tuscaloosa, AL: University of Alabama Press, 2008); Estrelda Alexander, Black Fire: One Hundred Years of African American Pentecostalism. (Downers Grove, III: IVP Academic, 2011).
} 
American roots of Pentecostalism. Thus MacRobert traces the origins of Pentecostalism all the way back to West Africa, and drawing on other historians of slave religion, contended that once in America, West African religious beliefs ultimately became Christian, yet "retained many African elements." 33 Furthermore, MacRobert gives multiple examples of churches that split and argues that while the splits were officially over doctrinal issues, the real reason was racism within southern churches. MacRobert concludes that "the white dominated Church of God who were so willing to suffer persecution for the sake of doctrine, conformed without any visible resistance to the racism of the South, and even ensured the continued domination of blacks by whites in their organization." ${ }^{34}$ Although MacRobert's book was less than 100 pages long, and thus too limited to fully address the subject for which the book was titled, his work was nonetheless an important step towards acknowledging the influences of African American intellectual and religious thought in the origins of the Pentecostal movement. Joe Newman expounded on the subject of race and racism in the early Pentecostal churches in his work, Race and the Assemblies of God Church. The formation of the Assemblies of God denomination in 1914 essentially marked the end of the interracial period of the Pentecostal churches. Like MacRobert, Newman argues that the Assemblies of God adopted more

\footnotetext{
${ }^{33}$ MacRobert argues that "an adequate comprehension of black Pentecostalism...can only be derived from a study of the religion which survived the middle passage in the hearts and minds of West Africans and their descendants." lain MacRobert, The Black Roots and White Racism of Early Pentecostalism in the USA, 2, 15.

34 Ibid, 67.
} 
segregationist and even racist attitudes towards blacks because of fear over losing support from their southern church leaders and congregations. This led to an unofficial policy of denying black ministers ordination in the Assemblies of God churches which excluded them from full participation in the churches. Other scholars push the idea of interracial divisiveness even further. ${ }^{35}$ This camp points to the swift formation of white Pentecostal churches in the early years as proof that the rhetoric of racial reconciliation did not match the reality on the ground.

Finally, scholars from a functionalist perspective tend to focus on socioeconomic explanations for the genesis and growth of the movement. Robert Mapes Anderson's Vision of the Disinherited was the first to expound on this idea. Using biographical and demographic data, Anderson argued that the early American Pentecostals were comprised of mostly poor and socially marginalized people, who saw Pentecostalism as a way to achieve a sense of power in their lives. Anderson compiled a study of 45 early Pentecostal leaders and determined that their common characteristics were their "mobility and their marginality." 36 Anderson contended that for individuals who saw themselves in a world system that was collapsing, "the Pentecostal message... provided a framework for the articulation in religious terms of what was largely social discontent." ${ }^{37}$ This

\footnotetext{
${ }^{35}$ Blumhofer went so far as to claim that the interracial nature of the revival is a "myth" without historical basis.

${ }^{36}$ These early leaders were mostly young, working class, minimally educated, and from a ruralagrarian background. Anderson also reasoned that due to their working class background, they probably experienced physical and/or psychological suffering in their youth and young adulthood. Robert Mapes Anderson, 1979. Vision of the Disinherited: the making of American Pentecostalism (New York: Oxford University Press. 113).

37 lbid.
} 
"social discontent" was ultimately rooted in the era of industrialization, and the transition from an agrarian based society to an industrialized society. For evidence, Anderson pointed to the ecstatic performances and millennialism beliefs of the practitioners. ${ }^{38}$ Anderson argued that religious ecstasy was the remedy for this severe social crisis, saying that "ecstasy was a mode of adjustment to highly unstable social circumstances over which they had little or no control." 39 This analysis marked a break from the earliest scholarly works on the Pentecostal movement, for while Hollenweger and Synan portrayed the Pentecostal movement in a generally positive light, Anderson was ultimately critical of the movement, saying that it "deflected social protest from effective expression, and channeled it into the harmless backwaters of religious ideology." ${ }^{20}$ Although more recent scholarship has been critical of Anderson's analysis, The Vision of the Disinherited is still cited as a foundational text on the history of the Pentecostal movement. ${ }^{41}$

\footnotetext{
${ }^{38}$ Defining Millenarianism as a belief that the existing world was totally depraved and incapable of redemption, Anderson argued that "this view accurately reflected the real social world of the Pentecostals" as well as "the real world of most of the working poor and that of many others who were disrupted by the crisis of the 1890s and its aftermath." Anderson, Vision of the Disinherited. 229.

39 Ibid, 231.

$40 \mathrm{lbid}, 239$.

${ }^{41}$ While painstakingly documented, Anderson's Marxist-inspired thesis remains overly simplistic, did not take seriously the sincere beliefs of the Pentecostals themselves, and did not account for the diversity of the movement. Furthermore, his analysis ultimately left out the voices of the people who were actually engaged in the practice and growth of the Pentecostal movement. Nonetheless, it had a tremendous effect on the field, and many scholars have since wrestled with Anderson's thesis whether by focusing on the sociological origins of the movement, the individuals involved, or the theology of the early Pentecostals.
} 
A few themes characterize the historiography of Pentecostalism. First, historians have tended to view Pentecostals generally as at best, misguided millennialist populists, and at worst, regressive conservatives. Arising in parallel with fundamentalist Christianity in the United States, Pentecostalism has received much of the same criticism as the fundamentalists. In South African scholarship, they fare no better, and are often derived as "disappointing subalterns" by Western scholars. ${ }^{42}$ Second, much of the historiography tends to assume a fundamental change in Pentecostalism during the mid-twentieth century. Where the early Pentecostals are labeled as regressive, conservative, apolitical, and primitive, contemporary Pentecostals are typically viewed as ultramodern, progressive, political capitalists. Edith Blumhofer provides an example of this in Restoring the Faith: The Assemblies of God, Pentecostalism, and American Culture, which details how the Assemblies of God went from a culturally isolated sect to an affluent, powerful, global denomination thoroughly enmeshed in American culture. Third, a weakness of the historiographical field is that individual Pentecostals are overshadowed by the larger theological elements of the movement. By focusing on theology, structure, and theory, the analysis often glosses over or ignores entirely the actions and agency of the individuals involved in the movement. Finally, although Pentecostalism is a historically global religious movement, North America dominates much of the scholarship.

\footnotetext{
42 David Maxwell, African Gifts of the Spirit: Pentecostalism \& the Rise of a Zimbabwean Transnational Religious Movement. (Oxford: James Currey, 2006), 10.
} 
Although Pentecostalism originated in the United States, its theology and practice have easily transcended national boundaries. ${ }^{43}$ The historiography has focused on answering the question of why Pentecostalism became the most influential mass religious movement of the twentieth century. In doing so, the tangible questions of how Pentecostalism became a dominant force is sometimes overlooked or obscured. This is partially out of a scarcity of sources that would give scholars a better view of the early Pentecostals' financial dealings and organization: the early Pentecostals were so focused on the mission that they failed to leave behind detailed church records that would offer the same sort of scrutiny for other church histories. However, the Pentecostals did leave one sort of source in abundance: periodicals. The Pentecostals left behind a lengthy and deep trail of periodicals that showcase their networks, beliefs, work, disagreements, failures, and successes. These sources have been approached by historians as a source worthy of plundering for piecing together the movement, but they have rarely been viewed as the source of the Pentecostal's early success in and of themselves. This is partially because the sources are full of accounts of the supernatural, and therefore can be difficult to unravel because they deal with seemingly eccentric beliefs and claims of supernatural acts. This project takes the beliefs and claims of these actors

\footnotetext{
${ }^{43}$ For transnational Pentecostalism see: André Corten and Ruth Marshall. Between Babel and Pentecost: Transnational Pentecostalism in Africa and Latin America. (Bloomington: Indiana University Press, 2001); and Donald E. Miller, Spirit and Power: The Growth and Global Impact of Pentecostalism. (New York: Oxford University Press, 2013), 185-224.
} 
seriously; for it is clear from their testimonies and writings that they wholeheartedly believed in this movement. The question of whether or not their claims were "real" is not as important as the fact that they believed they were real. Instead of examining why Pentecostals held such beliefs, this study focuses on how they imagined themselves, how they communicated their beliefs, and how they crafted a movement.

This dissertation contributes to the scholarship in three ways. First, it examines South Africa, a locale that has not received enough attention in the field, despite a history of record growth. Instead of treating South Africa as a case study, in this dissertation I seek to show how the medium of print drew South African Pentecostals into a larger transatlantic, and yea global world. By utilizing a transatlantic and regional perspective, I illuminate the continuities and discontinuities of the Pentecostal movement in the South African context.

Second, it answers the call of David Maxwell, a prominent historian of Pentecostal and Charismatic movements in Africa, to investigate the muchneglected material history of the movement. ${ }^{44}$ To do so the project investigates the means of production that characterized serial publication by examining the editors, subscribers, writers, publishers, readers and advertisers who collectively maintained these periodicals in a worldwide "pneuma" network. Through these periodicals, believers were drawn into and collaboratively constructed a textual

\footnotetext{
${ }^{44}$ David Maxwell, "Networks and Niches: The Worldwide Transmission of the Azusa Street Revival" in The Azusa Street Revival and Its Legacy by Harold D. Hunter and Cecil M. Robeck Jr., Eds., (Eugene, OR: Wipf and Stock Publishers, 2006), 129.
} 
community of believers with a common discourse of belief and goals that could yet still be adapted in local environments. This study examines how these Pentecostal print networks worked to craft a core identity and community regardless of geographical or national boundaries, or ethnic and cultural differences.

Finally, this project utilizes underused Pentecostal periodicals and it seeks to understand what Pentecostals had to say about the meaning and significance of their mission in South Africa. It contributes to our understanding of Pentecostalism in the South African context by examining the Apostolic Faith Mission of South Africa's main periodical, The Comforter and Messenger of Hope, and how the group used the medium of print to grow and sustain their mission in this specific context. It also investigates the role of U.S. Pentecostal periodicals in portraying South Africa to audiences in the United States. By showing how Pentecostals imagined themselves and built a movement, I implicitly argue for understanding the early Pentecostals as intentional in their pursuits. Although they were affected by the era in which they lived, Pentecostals were not simply religious populists reacting to the social turbulence of the time, nor were they unaware in the scope of their project.

Vinson Synan stated that "Parham laid the doctrinal foundation of the movement while Seymour served as the catalytic agent for its popularization." 45 This dissertation expands on this argument by illuminating the others involved in

\footnotetext{
${ }^{45}$ Vinson Synan, The Holiness-Pentecostal Tradition: Charismatic Movements in the Twentieth Century. (Grand Rapids, Mich: W.B. Eerdmans Pub. Co, 1997), 170.
} 
the catalytic process and how they popularized Pentecostalism, particularly in other parts of the world. The dissertation argues that the success of the movement in its early years can be attributed to a popular liturgy that emphasized a theology of the "democracy of the Spirit," combined with a utilization of the modern periodical and American publishing practices. South African Pentecostals fundamentally upended the conception of missions by rejecting the label of a church and promoting themselves as a renewalist apostolic movement instead. Despite their aversion to sectarianism, they actively worked to "brand" their movement through aggressive promotion and consolidation of other Protestant groups into the Pentecostal fold, thereby ensuring that they would not simply remain a localized religious sect.

This "branding" and message were not in step with reality on the ground. The first generation of Pentecostals preached racial equality and nonsectarianism, but it didn't last in practice. The cosmopolitan idealism printed in their periodicals most often did not translate into egalitarianism on the ground. Their main mission was saving souls for heaven, not to build a new church on earth. This proved extraordinarily attractive to an incredibly diverse range of people worldwide. The Pentecostals, more than any other Protestant group of this era, helped to modernize evangelicalism for the twentieth century. They not only became the fastest-growing "third force" of Christianity, but also influenced nearly every American Protestant denomination in existence, and charted the course for the current manifestation of Christianity in the world today. 
From the Protestant Reformation to the American Revolution, the printed word has been a driving force in the great revolutions in human history. ${ }^{46}$ In religious history, the influence of print is even more pronounced. This dissertation treats the periodical as a modern medium for religious branding, communication, and networking. In his analysis of nationalism, the anthropological historian Benedict Anderson argued that the rapid development of print and the proliferation of books led to the development of what he deemed "imagined communities," which were socially constructed communities formed around national print-languages. ${ }^{47}$ This theory can also be applied to the realm of religion. Print culture and the rise of the modern periodical is integral to understanding the advent and growth of Pentecostalism in the twentieth century. It was the perfect medium to take a message of sanctified unity to first a national and then a global audience. Religion and print culture have always enjoyed a close relationship in the U.S. Religion was the focus of the first specialized

\footnotetext{
${ }^{46}$ For general works on printing and change, see: Elizabeth L. Eisenstein, The Printing Press As an Agent of Change: Communications and Cultural Transformations in Early Modern Europe. (Cambridge, UK: Cambridge University Press, 1979); David S. Kaufer, and Kathleen M. Carley, Communication at a Distance: The Influence of Print on Sociocultural Organization and Change. (Hillsdale, NJ: Erlbaum, 1993); and David Zaret, Origins of Democratic Culture: Printing, Petitions, and the Public Sphere in Early-Modern England. (Princeton, N.J.: Princeton University Press, 2000).

For more on how printing technology expanded the public sphere see Carl F. Kaestle and Janice A. Radway, Print in Motion: The Expansion of Publishing and Reading in the United States, 18801940 (Chapel Hill: University of North Carolina Press, 2008); James Danky, Wayne Wiegand, and Elizabeth Long, eds., Women in Print: Essays on the Print Culture of American Women from the Nineteenth and Twentieth Centuries (Madison: University of Wisconsin Press, 2006); and Paul Starr, The Creation of the Media: Political Origins of Modern Communication (New York: Basic Books, 2005).

${ }^{47}$ See Benedict Anderson, Imagined Communities : Reflections on the Origin and Spread of Nationalism. (London: Verso, 2006).
} 
American periodicals. ${ }^{48}$ The Pentecostals drew from a rich well of religious print culture in America in their adaptation of the periodical for their evangelistic needs. As a thoroughly modern mass religious movement, Pentecostalism could not have emerged prior to modern communication, transportation, and mass printing. Periodicals removed the need for a traditional hierarchal church organization and established new pathways of publicness. It gave agency to the individuals involved in the movement, and erased traditional boundaries to church growth. Pentecostal periodicals drew together different printing traditions from cultures around the world.

The periodical remains one of the best sources for understanding how Pentecostals built and sustained the movement in its early decades. Scholars have long noted the critical role that religious periodicals have played in shaping the religious, social, and political landscape of the country. Since the eighteenth century, "popular periodicals have been a major means of promoting personal religious commitment and of nurturing individual piety while advancing causes of denominations, new religious movements, and agencies calling for social reform." ${ }^{49}$ Aversion to critical engagement with the periodicals has led to the "cherry-picking" of information from these periodicals instead of viewing them as wholly worthy objects of scrutiny. This has been an issue with the study of periodicals and other serials like newspapers at large. In their essay on the rise

\footnotetext{
${ }^{48}$ Ken Waters. "Vibrant, But Invisible: A Study of Contemporary Religious Periodicals" J\&MC Quarterly. Vol 78, No. 2. Summer 2001, 307-320. 307.

${ }^{49}$ P. Mark Fackler and Charles H. Lippy, Popular Religious Magazines of the United States. (Westport, CT: Greenwood Press, 1995), xvii.
} 
of periodical studies, Sean Latham and Robert Scholes note the intertextuality inherent in studying periodicals. Historians have, as Latham and Scholes suggest, "often been too quick to see magazines merely as containers of discrete bits of information rather than autonomous objects of study." ${ }^{50}$ Periodicals functioned as spaces of collaboration among groups that transcended national borders.

The Pentecostal periodicals are unique cultural and material objects. The study of these sources offers new insights into the workings of the movement in its early years. Comprised of sermons, news (both mission-related and secular), testimonials, advertisements, board reports, obituaries, wide-ranging articles, poetry, and music, these texts provide scholars with a richer picture of the people and practice of this movement than one might gleam from other sources. As products of consumption, they provide an avenue to understand the ways in which Pentecostal literature intertwined with the culture of commerce and the social, political, and cultural events of their time.

While many scholars have chosen to conceptualize Pentecostalism as a fundamentally primitive reaction against the times, others, like historian R. G. Robins, contend that early Pentecostalism was a fundamentally modernist movement. ${ }^{51}$ This dissertation aligns with that view. Pentecostals embraced many of the qualities associated with modernity. This was nowhere more evident

\footnotetext{
50 Sean Latham and Robert Scholes, "The Rise of Periodical Studies". PMLA. 121, no. 2 (2006): 517-531. 517.

${ }^{51}$ See R. G. Robins, A.J. Tomlinson: Plainfolk Modernist. (Oxford: Oxford University Press, 2004).
} 
than in their use of periodicals. As an object of modernity, the periodical reflected the spirit of the times. In their article on the rise of periodical studies, scholars Sean Latham and Robert Scholes make the case that modernism arrived with the advent of the modern magazine: "Modern culture was created from a still obscure alchemy of commercial and aesthetic impulses and processes. And this mixture was most visible in magazines..." 52 For all these reasons, this study is a cultural history of The Comforter and Messenger of Hope, the first South African Pentecostal periodical, and its predecessor, The Apostolic Faith. This dissertation traces the previously untold history of these periodicals in the context of their times.

The dissertation is organized in two parts; the first examines the foundations of the movement in America and the importance of Azusa Street to the subsequent growth of the movement globally. The second part follows the movement to South Africa and investigates its growth in that country through its publication, The Comforter/ De Trooster. Chapter one explores the roots of the American Pentecostal movement in the late nineteenth and early twentieth century. It begins by exploring the historical context of the U.S. in the late nineteenth century and investigates the particular changes in American religion that occurred during this period which led to the emergence of new spiritual groups including the Holiness movement, the precursor to modern Pentecostalism. After surveying the current historiography on the origins of

52 Latham and Scholes, "The Rise of Periodical Studies," 521. 
American Pentecostalism, this chapter argues that the modern Pentecostal movement emerged as a result of the general turbulence taking place in American society due to increasing industrialization and modernization, and as a specific response to the perceived de-spiritualization of religion in the country. It shows how the rise of mass communications, and in particular the development of religious print networks during this period accounts for the specific timing of the movement. Finally, the chapter examines some of the key individuals of the early movement in order to illuminate their contributions to the development and growth of the movement.

Chapter two delves into the Azusa Street Revival in Los Angeles, 1906 which I argue served as the launching point for the modern Pentecostal movement. ${ }^{53}$ The chapter begins with an overview of the city of Los Angeles as a model of the changes discussed in the previous chapter. It then investigates the revival as it was reported on in the local and national press at the time, and as participants described it in their own words. It then scrutinizes the participants and leaders of the revival and their beliefs. The goal of this chapter is to understand the place of Azusa in the history of the Pentecostal movement. There are several schools of thought that have dominated the discussion of the affair. Although scholars disagree on the origins of Pentecostalism, most concur that the Azusa Street Revival played an important role in catalyzing the movement to

\footnotetext{
${ }^{53}$ While most historians consider Azusa Street to be an important component and even the catalyst for the modern Pentecostal movement, I position myself with some, like Espinosa and Wacker, who view it as critical.
} 
worldwide success. This chapter seeks to understand why Azusa attracted the attention that it did in 1906, and what this says about its place in history. This chapter argues that modern Pentecostalism is best understood as an American religious phenomenon that went global for three primary reasons: First, the location of the revival in one of the booming metropolises of the American West created the environment in which this this event could take place and made it easy for the event to get noticed once it was underway; second, the demographic composition of the revival crossed many social barriers, making it instantly controversial in the religious and secular press; third, the leaders of the revival advocated a radical message of democratic unity in the Spirit; and finally, the revival occurred in a context of unprecedented millennialism and apocalypticism, particularly among religious groups that were most connected to vast communication networks.

Chapter three examines the organ of the Azusa Street Revival and Mission: the Apostolic Faith. The Apostolic Faith periodical was a model for dozens of Pentecostal periodicals that followed. This chapter examines all the elements of production of The Apostolic Faith. It analyzes the layout and content of the periodical as well as the messages within its pages. The goal of this chapter is to understand how the periodical helped to "brand" the revival as the place of God's new Pentecost, and therefore branding the Pentecostal movement as a whole. In this endeavor, I examine how the editors framed the conversation of the movement, and how they used modern methods of publishing to craft a narrative of the burgeoning movement. I argue that The 
Apostolic Faith is central to understanding how Pentecostal identity was formed in the early years.

Chapter four explores the first five years of the Pentecostal movement in South Africa. It begins with an overview of the social, political, and cultural background of the country itself and then investigates the peculiarities of religious life in the territory before the first Pentecostal witnesses arrived in 1908. After examining the current historiography of African Pentecostalism, it offers a new examination of the movement in South Africa. It does so by exploring first, the biographies of the missionaries; second, their replication of the Azusa Street revival in Doornfontein, Johannesburg; and thirdly, their mission building project in the territory. It argues that the Africa Pentecostals resembled and replayed the successes of the Apostolic Faith Mission at Azusa, with particular reference to theology, forms of worship, and critically, their use of print media. The Apostolic Faith Mission of South Africa was successful where others failed due to this close replication, but it also suffered from similar infighting and eventual racial discord.

Chapter five contends that the South African Pentecostals successfully adapted the Apostolic Faith Mission "brand" of Pentecostalism to the South African context by utilizing the effective evangelizing methods of the Los Angeles Apostolic Faith Mission, particularly through the medium of print. While revivalism and Holiness theology had impacted South Africa in the years prior to the arrival of the first Pentecostal missionaries, the country lacked a robust religious print culture like that in the US. The Apostolic Faith Mission nonetheless quickly instituted and slowly built a substantial subscription base for their periodical The 
Comforter/Die Trooster. ${ }^{54}$ The Comforter fulfilled several crucial purposes for the mission. First, it helped to "brand" the mission as a distinct religious entity in a country overflowing with various religious groups; second, it served as advertising for the mission, as it was able to reach people farther and faster than individual missionaries; third, it provided theological assistance to workers in the field; fourth, it helped build up a Pentecostal lexicon and mold the theological discourse of the movement; fifth, it extended the revival to those who could not physically attend, thereby creating a textual community of Pentecostals in the country; finally, it connected South African Pentecostals to a wider, global community.

Chapter six scrutinizes the Apostolic Faith Mission in the 1913-1928 period. It begins with an overview of the changing political and social climate of the country, and follows with an overview of the general religious trends. It then focuses on the tenure of the AFM president P.L. le Roux, and his leadership of the AFM after the departure of the original American Pentecostals. This chapter argues first that le Roux began the process towards bureaucratization and institutionalization of the Apostolic Faith Mission in South Africa. This process ensured the survival of the mission after years of financial problems and general instability under the tenure of John G. Lake, but that it also made the mission

\footnotetext{
${ }^{54}$ Originally entitled "God's Latter Rain." The later full title was "The Comforter and Messenger of Hope" or "Die Trooster en Boodschapper der Hoop" in Afrikaans. For clarity, I will reference the periodical as "The Comforter" for the English and English/Afrikaans duel versions and as "De Trooster" for the Afrikaans only version in the text of the dissertation. The footnotes will reflect the publication titles.
} 
less democratic and more political. Secondly, this chapter contends that South African Pentecostals were at least passively political, in the sense that the white mission's tolerance for the governmental segregationist ideology, and the black missions' resistance to the same were politically charged positions. Third, this chapter examines how the political realities of increasing racial segregation challenged the Pentecostals' allegiance to the "democracy of the spirit" within the churches. This chapter investigates two of the resulting schisms: First, the breaking away of black members to form the Zion Christian Church in 1919, and second, the Latter Rain schism led by women in 1928. I argue that church leaders consciously overlooked these schisms in their press, instead using the press to mold and unify discourse on matters of theology and practice. In particular, the press helped to shift understandings of ecclesiastical unity from the radical racial egalitarianism of its roots to a more institutionalized understanding of unity as "separate but equal."

Finally, chapter seven examines the Apostolic Faith Mission in the 1920s1948 period, and its organ The Comforter. During the Depression and War years, the AFM experienced extraordinary growth and development, becoming one of the fastest growing and largest denominations in the country. This chapter records the AFM's slide towards the embrace of the South African government's policy of racial segregation, while at the same time increasing their presence in the country and the world through the medium of print. This chapter charts the resurgence of The Comforter in the 1930s. This chapter argues that during the 1930s-1940s The Comforter/Trooster periodical transitioned from a localized 
mission paper to a Pentecostal magazine with an international scope. To accomplish this, this chapter investigates first, the social, economic, and political context of the era; second, the management of the paper under the tenure of Le Roux until 1920; third, the management of David Du Plessis beginning in the 1920s; fourth, the evolution of the paper during the 1930s, with a focus on how the mission employed new marketing, advertising, and promotional tactics that contributed to the growth of the paper; and fifth, the full transformation of the paper in the 1940s into a cosmopolitan religious magazine. At the height of the 1930s-40s period The Comforter was incorporating writings from some of the most famous evangelicals in the world. I argue that in doing so, The Comforter, and other Pentecostal periodicals like it, created a global community of Pentecostals that supported the dominance of the faith for the twentieth century. 


\section{CHAPTER 1:}

\section{TURBULENT BEGINNINGS: ROOTS OF PENTECOSTALISM 1880s-1906}

While this study explores the meanings of the Pentecostal movement in South Africa in the first decades of the last century, that phenomenon is properly understood in the context of the origins of the Pentecostal movement in the United States with the Azuza Street revival in Los Angeles in 1906. That spiritual awakening itself, however, derives its greatest significance in the context of American history in the tumultuous decades of the Civil War and Gilded Age. This chapter offers that overview. It does so by examining the four critical elements of the period that gave rise to the Pentecostal movement as the twentieth century dawned. It surveys 1) the economics, society, and politics of the period; 2) its religious climate; 3 ) the impact of science, specifically Darwinism on the culture; 4) the rise of new manifestations of faith in the period; 5) the critical figures who emerge as the precursors to the modern Pentecostal movement. In all these categories, the chapter emphasizes the disintegration of traditional views and the rise of new systems and order, however inchoate.

Pentecostalism arose on the eve of the twentieth century, at a time of tumultuous changes in American society, politics, and culture, as the nation struggled towards consolidation after the crises of the mid-century. ${ }^{1}$ While the long theological genealogy of Pentecostalism is well documented, the specific

\footnotetext{
${ }^{1}$ Elliott West, "Reconstructing Race”. The Western Historical Quarterly 34, no. 1 (2003): 21.
} 
historical realities in which it manifested require further interrogation. ${ }^{2}$ The American historical context is crucial to understanding why this particular strain of Christianity emerged when it did, and perhaps even more critical to understanding how and why the movement experienced such tremendous and sustained growth over the course of the twentieth century. Pentecostalism is both an effect of larger global religious trends occurring at the twilight of the nineteenth century and a reaction to specific transformations in American religion and society following the American Civil War. While Pentecostalism is now a global religion, it was born distinctly American.

The decades that flanked the turn of the twentieth century were defined by transformations in nearly every aspect of American society. America's technological base was exploding in this period in ways that affected every facet of American life. It was a time of unparalleled progress and innovation. The year 1866 saw the opening of the Atlantic cable, making transatlantic communication between the U.S. and Europe possible via electronic telegraph. The period of

${ }^{2}$ For more on the theological origins of Pentecostalism see: Edith L. Blumhofer, "The 'Overcoming Life': A Study in the Reformed Evangelical Origins of Pentecostalism." (Ph.D. diss., Harvard University, 1977; Donald W. Dayton, "The Higher Christian Life": Sources for the Study of the Holiness, Pentecostal and Keswick Movements. (New York, Garland Publishing, 1984-85); Donald W. Dayton, Theological Roots of Pentecostalism. (Grand Rapids, MI: Francis Asbury, 1987); Faupel, D. William. The Everlasting Gospel: the Significance of Eschatology in the Development of Pentecostal Thought. (Sheffield, England: Sheffield Academic Press, 1996); Hollenweger, Walter J. The Pentecostals: The Charismatic Movement in the Churches. (Minneapolis, Augsburg, 1972); Vinson Synan, ed. Aspects of Pentecostal/Charismatic Origins. (Plainfield, Logos, 1975); Robert Mapes Anderson, Vision of the Disinherited: The Making of American Pentecostalism. (New York, NY: Oxford University Press, 1979); Douglas Gordon Jacobsen, Thinking in the Spirit: Theologies of the Early Pentecostal Movement. (Bloomington, IN: Indiana University Press, 2003); and Vinson Synan, The Holiness-Pentecostal Tradition: Charismatic Movements in the Twentieth Century. (Grand Rapids, Mich: Eerdmans, 1971). 
$1865-1900$ witnessed a tremendous amount of inventions that fundamentally transformed the way that Americans lived, including the typewriter, stock ticker, barbed wire, telephone, phonograph, incandescent lightbulb, Kodak camera, electric stove, and tape recorder. The era's greatest inventor, Thomas Edison, developed 1,093 patents on his technological inventions in the U.S. alone and ushered in an era of mass communication, particularly through telecommunication. By the late nineteenth century, electricity had become a part of urban American life. However, the rapid changes of the times also contributed to increasing destabilization in American life.

The railroads were an icon of transformation and destabilization. The rise of mass communication paralleled developments in transportation, particularly via the expansion of railroads across the U.S. The railroad became the symbol of American technology and progress, as well as corruption. The First Transcontinental Railroad was completed in 1869, ushering in a period of unprecedented mobility for many Americans. Railroad companies exploded as a part of the post-war economy, serving as the largest nonagricultural employers. ${ }^{3}$ Telegraph wire accompanied the laying of rail, advancing the speed of communication. The expansion required heavy risk capital investment that the government provided in the form of land grants and loans. ${ }^{4}$ Government funding fueled unbridled speculation and expansion and fed corruption in the form of

\footnotetext{
${ }^{3}$ James M. McPherson, Ordeal by Fire: The Civil War and Reconstruction. (New York: McGrawHill, 1992), 576.

${ }^{4}$ Ibid, 577.
} 
padded government construction contracts. Taxpayers were left on the hook when railroad companies went bust. Furthermore, although rail connected towns and local farmers with a network of distant markets, this put them at the mercy of freight prices, which the railroad companies often exploited to their advantage. Even when the prices of corn and wheat dropped by half during the 1867-1872 period, railroad freight rates barely moved, and the farmers blamed the rails for their misfortunes. ${ }^{5}$

During this era advances in technology combined with economic forces corroded the Jeffersonian ideal of the small, stable, yeoman farmer. ${ }^{6}$ Increased production and increasing debts, combined with crop specialization at the expense of subsistence crops led to a dependence on the marketplace. ${ }^{7}$ Combined with exorbitant railroad fees and evaporating farm prices, small farmers were often faced with selling and moving to the cities or eking out a marginal existence as a poor tenant or subsistence farmer. The South in particular went through a wrenching period of transition from slave-labor to freelabor economy. In the post-war years cotton prices plummeted, and large plantations were broken up into small farms worked by the Freedmen and poor whites. ${ }^{8}$ Sharecropping became particularly widespread in the South, where the

\footnotetext{
${ }^{5}$ Ibid, 577-78.

${ }^{6}$ T. J. Jackson Lears, Rebirth of a Nation: The Making of Modern America, 1877-1920. (New York: HarperCollins, 2009), 136-140.

${ }^{7}$ Charles W. Calhoun, The Gilded Age: Perspectives on the Origins of Modern America. (Lanham, MA: Rowman \& Littlefield Publishers, 2007), 285.

${ }^{8}$ See Charles S. Aiken, The Cotton Plantation South Since the Civil War. (Baltimore: Johns Hopkins University Press, 1998); and Roger L. Ransom and Richard Sutch, One Kind of
} 
low price of cotton ensured that sharecroppers remained poor. While freedmen initially saw their conditions improve, they quickly returned to a cycle of poverty. Many simply left their homes for more promising circumstances elsewhere. This was an era of transience, with individuals and families often uprooting and taking advantage of new, more affordable means of transportation in order to pursue a better life.

The instability of the American economy was the underlying source for much of the era's political and social turbulence. While the gross national product soared from $\$ 11$ billion in the mid-1880s to $\$ 84$ billion in $1919,{ }^{9}$ the economy experienced a series of boom and bust cycles that make consistent employment difficult for many working class families. The rise of big business dominated the era. Steel production rose from $5,865,000$ tons in 1889 to $11,227,000$ tons a year by 1900 , while in the same time period total manufacturing capital rose from $\$ 5,677,000,000,000$ to $\$ 8,663,000,000,000 .{ }^{10}$ Business tycoons like Jay Gould, John D. Rockefeller, and Andrew Carnegie represented the success of the freewheeling capitalism of the period. Carnegie's philanthropy was a response to the social disorder of the period, yet the success and extravagant lifestyle of big businessmen of the era stood in stark contrast with much of the working and

\footnotetext{
Freedom: The Economic Consequences of Emancipation. (Cambridge, England: Cambridge University Press, 1977).

${ }^{9}$ Nell Irvin Painter, Standing at Armageddon: The United States, 1877-1919. (New York: W.W. Norton, 1987), xvii.

10 United States Department of Commerce, Bureau of the Census, Historical Statistics of the United States (1975), 693-94, 684, 818. As quoted in Nell Irvin Painter, Standing at Armageddon, $x v i i$.
} 
middle class. The rise of big business, corporate consolidation, and urban industrialization brought particular challenges to the working class. Machines replaced skilled labor, employment was vulnerable to the seasons of economic downturn, and "industrial salaries generally decreased." 11 Working conditions in urban settings were often unregulated and paid low wages. Workers made use of the strike to compel businesses to improve working conditions, for "the group was more important than the individual; individualism was an ideology for the rich and well born - or so it seemed, at any rate."12

Massive immigration contributed to destabilization. This "Age of Mass Migration" profoundly affected American society. From 1846 to 1876 the immigration rate averaged approximately 300,000 per annum. The rates increased dramatically from then on and by the turn of the century the immigration rate had breached one million migrants per annum, ${ }^{13}$ mostly poor and unskilled workers. ${ }^{14}$ The era also oversaw tremendous internal migration. In his treatise on the American West, Richard White writes that the greatest challenge to Western communities lay in the unprecedented numbers of "single, mobile men" who traveled west. ${ }^{15}$ While men made up the majority of

\footnotetext{
${ }_{11}$ Paul A. Shackel and Matthew M. Palus, "The Gilded Age and Working-Class Industrial Communities." American Anthropologist, 108, No. 4 (December 2006), 829. Published by: Wiley on behalf of the American Anthropological Association, accessed January $9^{\text {th }}, 2016$. http://www.jstor.org/stable/4496522

12 Jackson Lears, Rebirth of a Nation, 74.

${ }^{13}$ T. J. Hatton and Jeffrey G. Williamson. The Age of Mass Migration: Causes and Economic Impact. (New York: Oxford University Press, 1998), 7-8.

${ }^{14}$ Hatton and Williamson, The Age of Mass Migration, 12.

${ }^{15}$ Richard White, It's Your Misfortune and None of My Own: A New History of the American West.
} 
unattached, they were far from the only "rootless" group in the new territories. Many newly freed black Americans struck out towards the West and the North, often under the auspices of the Freedman's Bureau. ${ }^{16}$

The economic and social unrest affected the nation's political climate in profound ways. The period of the late 1800 s witnessed surging political involvement by average Americans. Civil War and Reconstruction issues dominated the parties until the compromise of 1877 , which settled the 1876 Presidential election by granting Republican candidate Rutherford B. Hayes the uncontested position of Presidency for a number of Democrat conditions, including removal of all U.S. military troops from the former confederate states. ${ }^{17}$ Reformers and the freedmen, along with northern businessmen favored the Republican Party, while the Democratic Party contained the former confederates. The Democrats retook the House of Representatives in 1875, and populism surged as a movement that sought to address problems associated with industrialization. ${ }^{18}$ Third parties like the Prohibition Party, Greenback Party, and Populist Party gained popular support from widespread anti-establishment party

\footnotetext{
(Norman: University of Oklahoma, 1993), 302.

${ }^{16}$ Janette Thomas Greenwood, First Fruits of Freedom: The Migration of Former Slaves and Their Search for Equality in Worcester, Massachusetts, 1862-1900. (University of North Carolina Press. 2009), 5-6, accessed September $7^{\text {th }}, 2015$. http://www.jstor.org/stable/10.5149/9780807895788_greenwood.

${ }^{17}$ See discussion in James M. McPherson, Ordeal by Fire: The Civil War and Reconstruction. (New York: McGraw-Hill, 1992), 590-594.

${ }^{18}$ Richard Hofstader, The Age of Reform: From Bryan to F.D.R. (New York: Vintage Books, 1955), 61.
} 
sentiment. Distrust in the two party system was due to widespread corruption at nearly all levels of government.

The insurgents focused their attention on Wall Street bankers as well as politicians. Mary Elizabeth Lease, an American lecturer, writer, and suffragist, declared during a speech in 1890 that "Wall Street owns the country. It is no longer a government of the people, by the people, and for the people, but a government of Wall Street, by Wall Street, and for Wall Street. The great common people of this country are slaves, and monopoly is the master."19 Politicians at the local level fared no better in the public eye. Relying on a political system of patronage to retain support from business leaders and immigrant communities, city bosses such as William M. Tweed of Tammany Hall in New York City were known both for their efficiency as well as corruption. The South fared no better, and "by the 1880 s, public life in many Southern states was a cesspool of corruption." 20 In the aftermath of the Civil War, the Republican Party became the moral party, mainly by unifying the antislavery, anti-alcohol, and antiCatholic crowds, and they "had a strong Puritan-evangelical component, bent on regulating society according to Christian principles." ${ }^{21}$ The Democrats were left with the Catholics, the Southerners, and the outsiders.

\footnotetext{
${ }^{19}$ William Elsey Connelley, History of Kansas State and People: Kansas at the First Quarter Post of the Century. (Chicago: American Historical Society, 1928), 1167.

20 Jackson Lears, Rebirth of a Nation, 126.

${ }^{21}$ George Marsden, Understanding Fundamentalism and Evangelicalism. (Grand Rapids, MI: Wm. B. Eerdmans Publishing Co., 1991), 89.
} 
Social Darwinism formed much of the intellectual backbone of free competitive order of the period. Charles Darwin published his On the Origin of Species in 1859, and by the end of the nineteenth century many Catholics and evangelicals were taking note of the theory's growing influence. Social Darwinism - in essence the dogma of survival of the fittest - worked well as an ideology for imposing social order. Social Darwinism was a combination of Darwin's writings and the writings of Herbert Spencer, who published the bestselling book Social Statistics in 1851. It was Spencer who argued that "the struggle of humans for survival in a free, competitive environment was the engine that drove the progress of civilization." 22 The fittest individuals - those with the most ingenuity, strength, and determination - pulled society forward, while the unfit and weak were simply left to languish and die and thus "in doing so raise the societal average." ${ }^{23}$ For many Americans, Spencer's philosophy was welcome, since it justified their everyday lives, and segments of the country turned to secularism after the disillusionment of the war. ${ }^{24}$ For many American theologians however, Social Darwinism catalyzed the crisis in biblical authority.

The country's religious landscape was likewise undergoing tremendous shifts. By the turn of the twentieth century, the American religious landscape was

\footnotetext{
${ }^{22}$ Norman K. Risjord, Representative Americans: Populists and Progressives. (Lanham: Rowman \& Littlefield, 2005), 56.

${ }^{23}$ Ibid, 56.

${ }^{24}$ Raymond J. Cunningham, "From Holiness to Healing: The Faith Cure in America 1872-1892". Church History. 43, no. 4. (1974): 499.
} 
crowded, varied, divisive, and changing. One must look to the beginning of the nineteenth century in order to understand the religious transformations at its end. According to historian Nathan O. Hatch, the Second Great Awakening, a religious revival movement that began in the late 1780s and ended in the 1840 s, forever altered the development of Christianity in the United States by virtue of democratization. ${ }^{25}$ As a challenge to the "social control" interpretation of the Second Great Awakening, Hatch argues that

...we have ignored the most dynamic and characteristic elements of Christianity during this time: the displacement from power of the religious people of ideas by those who leaned toward popular culture; the powerful centrifugal forces that drove churches apart and gave new significance to local and grass-roots endeavors; and the stark emotionalism, disorder, extremism, and crudeness that accompanied expressions of the faith fed by the passions of ordinary people. ${ }^{26}$

The American Revolution led to the fruition of the democratization of American religion. Religion was no longer tied to the state, but was purely voluntary and as Daniel Walker Howe points out in his work on the early republic, the subsequent explosion of religious organizations, societies, and associations in the late 18 th and early 19 th centuries actively "nurtured American democracy." ${ }^{27}$ People who were barred from democracy in the American political sphere were generally able to participate in these newly developed, less structured, and more democratic religious associations. African Americans were

\footnotetext{
${ }^{25}$ Nathan O. Hatch, The Democratization of American Christianity. (New Haven: Yale University Press, 1989).

${ }^{26} \mathrm{lbid}, 222$.

27 Daniel Walker Howe, What God Hath Wrought: The Transformation of America, 1815 - 1848. (New York: Oxford University Press, 2007), 166.
} 
one of these groups, and both free black and slaves converted to Christianity in high numbers during the early nineteenth century. ${ }^{28}$ The Second Great Awakening saw an increasing emphasis on personal religious experience and an Armenian theology that argued that anyone could be saved through their own efforts.

Liberal Christianity, which emphasized personal experience of the heart over abstract doctrines, was best embodied in the person of Henry Ward Beecher (1813-1887). ${ }^{29}$ Debby Applegate, a biographer of Beecher, called him "the father of modern Christianity," as Beecher symbolized many of the changes associated with the rise of liberal Christianity in this era. ${ }^{30} \mathrm{~A}$ social reformer and Congregationalist clergyman, Beecher's iconoclasm repudiated the strict theology of his own father, Lyman Beecher. A reformer but not a revolutionary, Beecher became famous for emphasizing the "Love of God" over the "Rule of Law." ${ }^{31}$ Beecher embraced the ideas of Herbert Spencer (1820-1903), the British social thinker who originated the term "survival of the fittest" and whose ideas

\footnotetext{
${ }^{28}$ For more on the religion of enslaved people in the United States, see: Albert J. Raboteau, Slave Religion: The "Invisible Institution" in the Antebellum South. (New York: Oxford University Press, 1978); David Emmanuel Goatley, Were you there?: Godforsakenness in Slave Religion. Bishop Henry McNeal Turner/Sojourner Truth series in Black religion, v. 11. (Maryknoll, N.Y.: Orbis Books. 1996); and Sylvia R. Frey and Betty Wood, Come shouting to Zion: African American Protestantism in the American South and British Caribbean to 1830. (Chapel Hill: University of North Carolina Press, 1998).

${ }^{29}$ Grant Wacker, Religion in Nineteenth Century America. (New York: Oxford University Press, 2000), 134.

${ }^{30}$ Debby Applegate, The Most Famous Man in America: The Biography of Henry Ward Beecher. (New York: Doubleday, 2006).

31 lbid, 13.
} 
predated Darwin's Origin of The Species. ${ }^{32}$ Later, Beecher fully embraced Darwin's theories as well, offering sermons on "Evolution and Religion." ${ }^{33}$ Yet Beecher also symbolized to many the worst aspects of this Protestantism, particularly when it came to corruption within the churches. In 1888 his alleged scandalous affair with a friend of his wife and the subsequent civil trial that ensued made the front pages of all the national newspapers and "created more headlines than the entire Civil War." ${ }^{34}$ Another manifestation of the vulgarization of liberalism, Beecher became a commercial huckster in his advertisements for Pears Soap Company. "If CLEANLINESS is next to GODLINESS," he asserted; "soap must be considered as a means of GRACE, and a clergyman who recommends MORAL things should be willing to recommend soap." ${ }^{35}$ Beecher's insistence on secularizing the sacred had its own polarizing effect. An outspoken abolitionist, many despised him for bringing "politics in the pulpit."36 Protestants pointed to the corruption and scandals of figures like Beecher and increasingly desired something better, purer, more authentic, and more Biblical.

\footnotetext{
32 Ibid, 355. See also: Benjamin T. Lynerd, 2015. "The Purpose-Driven Darwinist: Henry Ward Beecher and the Theology of Progress". Political Theology. 17, no. 1 (2016): 47-72. Doi: 10.1179/1462317X15Z.000000000145

${ }^{33}$ Applegate, The Most Famous Man in America, 461.

34 Ibid, back cover.

${ }^{35}$ Puck Magazine. New York, NY: Keppler \& Schwarzmann. Vol. 25, No. 624. May 1st, 1889. 172 , accessed June $12^{\text {th }} 2015$, https://books.google.com/books?id=rvggAQAAMAAJ\&pg=PA12\#v=onepage\&q\&f=false

${ }^{36}$ Henry Ward Beecher, "Preaching Christ" in Sermons by Henry Ward Beecher, Vol. 2. Plymouth Church, Brooklyn, NY. (New York: Harper and Brothers Publishers, 1868), 172.
} 
The American Civil War was as much a theological conflict for Americans as it was a social and political conflict. ${ }^{37}$ America's most prominent church denominations failed to reach a consensus on the issue of the Biblical interpretation of slavery prior to the war, and most of the mainline denominations foreshadowed the fracturing of the Union by splitting over the slavery issue. Historians have noted that this crisis in Biblical interpretation had dramatic consequences on American Protestantism. One of the critical effects was that American Protestants were fundamentally unable to resolve their disagreement over the issue of slavery. The Bible was supposed to be the Word of God and yet on such an issue American Protestants were deeply divided. Such division contributed to the breakdown in authority of the mainstream denominations. As historian Mark Noll has articulated, the Civil War had the effect of increasing the personal and spiritual meaning of scripture for many Americans, while simultaneously undermining the Bible itself as a force in American civilization. ${ }^{38}$ This turn inward, toward a more personal and spiritual meaning of the Bible left many American Protestants feeling that the mainstream denominations were lacking.

Another feature of the post war period was the increasing segregation of the mainstream Protestant churches. After the war African Americans left white churches en mass and formed black churches, typically Baptist and Methodist,

${ }^{37}$ See Mark A. Noll, The Civil War As a Theological Crisis. (Chapel Hill, NC: University of North Carolina Press, 2006).

$38 \mathrm{lbid}, 93-94$. 
which formed the backbone of black communities. ${ }^{39}$ This left very few racially integrated mainline Protestant churches. Ecclesiastical equality was a common concern for blacks that chose to leave biracial churches. ${ }^{40}$

Revivalism had been a crucial element of American religious history since the Great Awakening, and the post-Civil War years saw a recurrence of this particular phenomenon. The period after the Civil War was characterized by religious fervor that rivaled even the periods of the First and Second Great Awakening in American history leading historian William McLoughlin to label it America's "Third Great Awakening." ${ }^{\text {11 }}$ Although revivals characterized other western societies at this time, the more fundamentally religiousness of American culture made this third great awakening in the United States unique.

The famous evangelist Dwight L. Moody best represents this shift in focus. As historian Jackson Lears has suggested, this period was indeed "an age of regeneration. ${ }^{42 " ~ R e v i v a l i s m ~ w a s ~ a ~ r e l i g i o u s ~ m a n i f e s t a t i o n ~ o f ~ m a n y ~ A m e r i c a n ' s ~}$ search for regeneration. For many of the antebellum reformers, the Civil War had been the culmination of years of reform efforts to perfect American society. The

\footnotetext{
${ }^{39}$ Daniel W. Stowell, Rebuilding Zion: The Religious Reconstruction of the South, 1863-1877. (New York: Oxford University Press, 2001), 80.

$40 \mathrm{lbid}$.

${ }^{41}$ William McLoughlin, Modern Revivalism: Charles Grandison Finney to Billy Graham. (Eugene, Oregon: Wipf \& Stock Publishers, 1959), 168.

42 Lears, Rebirth of a Nation, 10.
} 
war left the country in a "moral depression" caused by poverty, religious disillusionment, and social upheaval. ${ }^{43}$

Biblical authority had been under assault for some time, particularly through Higher Criticism of the bible by German Protestants and New England Transcendentalists. Darwin's Origins gave scientific ammunition to these already established arguments that God worked through nature and was the intelligent cause behind any means of nature, including evolution. Writing of the impact of Darwin's work on nineteenth century Protestants, Historian Paul Conklin asserts that "justification for belief would have to switch from nature or from history to human experience, and thus to an authority immune from the ravages of biblical criticism or new understandings of nature." ${ }^{44}$ The transition in authority would have transformational effects on American Protestantism.

While these crises swirled about the church, the church itself was changing. These changes appear clearest in the theological concept of the millennium. ${ }^{45}$ In the second great awakening, post-millennialism had dominated the religious worldview of the revivalist, and indeed, of American religion. While that vision continued, essentially, if more secularized, in what would be the Social Gospel Movement, Premillennialism became a much more potent force in religious life, especially among the new sects of the Gilded Age. While these

\footnotetext{
${ }^{43}$ Synan, The Holiness-Pentecostal Tradition, 1997.

${ }^{44}$ Paul Keith Conkin, When All the Gods Trembled: Darwinism, Scopes, and American Intellectuals. (Lanham, MA: Rowman \& Littlefield Publishers, 1998), 39.

${ }^{45}$ Randall Herbert Balmer, The Making of Evangelicalism: From Revivalism to Politics, and Beyond. (Waco, Texas: Baylor University Press, 2010), 36.
} 
categories have somewhat different meanings, they are clear - with clearer

social consequence - in general. Post-Millennialism ${ }^{46}$ held that the 1000 year

period of grace had already begun and encouraged Christians to work cheerfully

and confidently within the world to improve it still further. ${ }^{47}$ This impulse

accounted for the Christian moral impulse behind much of the social reformism of

the 1830 s, '40s, and '50s. ${ }^{48}$ In contrast, pre-millennialism ${ }^{49}$ offered a much more

pessimistic vision of an unredeemed, even unredeemable world where salvation

was a purely individual enterprise and the church - the collection of the saved -

disassociated and detached from the world as Christians awaited the Millennium

\footnotetext{
${ }^{46}$ Postmillennialism was the belief that Christ will return after a one-thousand-year era of spiritual and cultural progress. It was fundamentally an optimistic eschatology of progress, based off a liberal interpretation of history and culture.

${ }^{47}$ Historians like William Mcloughlin have noted that major evangelists like Charles Grandison Finney were postmillennialists, who "saw no conflict between science and religion and who firmly believed that progress, in all its forms, was divinely directed toward the perfection of the world." William McLoughlin, Modern Revivalism: Charles Grandison Finney to Billy Graham. (Eugene, Oregon: Wipf \& Stock Publishers, 1959), 167. See also, James H. Moorehead, World Without End: Mainstream American Protestant Visions of the Last Things, 1880-1925. Bloomington: Indiana University Press, 1999. Xi; and George M. Marsden, Understanding Fundamentalism and Evangelicalism (Michigan: William B. Eerdmans Publishing Company, 1991), 33.

${ }^{48}$ Marsden, Understanding Fundamentalism and Evangelicalism, 33.

${ }^{49}$ Premillennialist eschatology assumed Christ's physical return was eminent, and would result in the rapture, in which the righteous would be raised up to heaven, and the unrighteous condemned to hell. This eschatology was based on a literal interpretation of Revelation 20:1-6, in which John describes a vision of the end times: "And I saw an angel come down from heaven, having the key of the bottomless pit and a great chain in his hand. And he laid hold on the dragon, that old serpent, which is the Devil, and Satan, and bound him a thousand years, And cast him into the bottomless pit, and shut him up, and set a seal upon him, that he should deceive the nations no more, till the thousand years should be fulfilled: and after that he must be loosed a little season. And I saw thrones, and they sat upon them, and judgment was given unto them: and I saw the souls of them that were beheaded for the witness of Jesus, and for the word of God, and which had not worshipped the beast, neither his image, neither had received his mark upon their foreheads, or in their hands; and they lived and reigned with Christ a thousand years. But the rest of the dead lived not again until the thousand years were finished. This is the first resurrection. Blessed and holy is he that hath part in the first resurrection: on such the second death hath no power, but they shall be priests of God and of Christ, and shall reign with him a thousand years." (King James Version)
} 
and Christ's triumphant return. ${ }^{50}$ Since the end was neigh, premillennialists saw nothing in the world worth saving aside from souls. "We do not despair," wrote W.E. Blackstone, author of the bestselling Jesus is Coming evangelical book in 1898, “... On the contrary, we are filled with a lively hope, the most blessed hope, while we strive to save some from this worldly, sinful and adulterous generation, which is nigh unto cursing and whose end is to be burned. We would not deceive them with the hallucination that they are "growing better." 51

No individual better represented this enormous eschatological shift than the most famous evangelist of the era, Dwight L. Moody (1837-1899)..$^{52}$ Moody was born in Massachusetts and raised in the Unitarian Church until the age of 18, when he converted to the Congregational Church through the efforts of his Sunday school teacher. During the $1857-58$ period of revivals Moody became

\footnotetext{
${ }^{50}$ For more on the rise of premillennialism see: David W. Faupel, The Everlasting Gospel: The Significance of Eschatology in the Development of Pentecostal Thought. (Sheffield, England: Sheffield Academic Press, 1996); Ernest Robert Sandeen, The Roots of Fundamentalism: British and American Millenarianism, 1800-1930. (Chicago: University of Chicago Press, 1970); Timothy P. Weber, Living in the Shadow of the Second Coming: American Premillennialism, 1875-1925. (New York: Oxford University Press, 1979); George M. Marsden, Fundamentalism and American Culture: The Shaping of Twentieth Century Evangelicalism, 1870-1925. (New York: Oxford University Press, 1980); Jean B. Quandt, "Religion and Social Thought: The Secularization of Postmillennialism". American Quarterly. 25, no. 4 (1973): 390-409; Matthew Avery Sutton, American Apocalypse: A History of Modern Evangelicalism. (Cambridge, Massachusetts: Belknap Press of Harvard University Press, 2014); and James H. Moorehead, World Without End: Mainstream American Protestant Visions of the Last Things, 1880-1925. (Bloomington: Indiana University Press, 1999).

${ }^{51}$ W.E. Blackstone, Jesus is Coming (New York, NY: Fleming H. Revell Co., 1898), 144. http://www.archive.org/details/JesuslsComing-raptureByWilliamW.e.b.Blackstone [Accessed 2/1/2016] The belief that "Jesus is coming soon" emphasized the importance of personal salvation, sanctification, and evangelism; factors that became foundational to the future Pentecostal movement.

52 For more on the life and impact of Moody on American evangelicalism, see: Lyle W. Dorsett, $A$ Passion for Souls: The Life of D.L. Moody (Chicago: Moody Press, 1997), and J.F. Findlay Jr, Dwight L. Moody: American Evangelist 1837-1899. (Chicago: University of Chicago Press, 1969).
} 
involved with the Young Men's Christian Association (YMCA), and he worked for the association diligently for decades. In 1871 he met Ira Sankey (1840-1908) at a YMCA convention in Indianapolis, IL. Sankey was an American gospel singer and composer, and would become renowned as of the most famous hymnists of all time. Moody and Sankey traveled as evangelists and conducted revivals throughout Europe (1873-1875) and America (1875-1879). At these revivals and conferences, Moody espoused his embrace of dispensational premillennialism. He also Moody famously declared that "I look upon the world as a wrecked vessel. God has given me a lifeboat and said, 'Moody, save all you can.'”53

Moody's greatest legacy lay in his development of the Bible School movement. In 1886 he founded the Bible-Work Institute of the Chicago Evangelization Society, which was renamed Moody Bible Institute shortly before his death. This institution gave birth to the Bible Institute Colportage Association (later named Moody Publishers) in 1894 for the purpose of publishing and distributing inexpensive Christian books. ${ }^{54}$ Moody's transformative impact on religious publishing helped usher in a new era of American evangelicalism that embraced mass communication as a means to further the gospel.

American religious print culture had an extensive lineage, but it exploded in the late nineteenth century with the development of the rotary printing press

\footnotetext{
${ }^{53}$ Quoted in Balmer, The Making of Evangelicalism: From Revivalism to Politics, and Beyond, 36. 54 "The Bible Institute Colportage Association," Moody Bible Institute. The Christian Workers Magazine, Vol 17, No. 6. (Chicago: Moody Bible Institute of Chicago, February, 1917), 496.
} 
and the linotype. ${ }^{55}$ The mid nineteenth-century saw the rise of a distinctly American type of monthly magazine. Religious groups contributed to the proliferation of periodicals, ushering in a new era of evangelism. Mainstream churches used monthly or quarterly serials to circulate their particular brand of evangelical truth and to refute unsound doctrine, particularly from other denominations. ${ }^{56}$ Evangelicals wholeheartedly embraced the medium of print for advancing the kingdom of God on earth. Groups like the American Tract Society and other benevolent organizations utilized publications and tracts in order to reach as many as possible for as cheaply as possible. ${ }^{57}$ Print proved to be one of the most efficient means of communicating the gospel to the thousands migrating to the Midwest. One excited clergyman noted in the Religious Telescope of 1839 that "a well conducted religious periodical is like a thousand preachers, flying in almost as many directions by means of horses, mailstages, steamboats, railroad cars, ships... offering life and salvation to the sons of men in almost every clime." ${ }^{58}$ This new form of proselytizing was especially beneficial for less

\footnotetext{
${ }^{55}$ For an introduction to the impact of technological advances in printing presses on the development of the modern magazine, see: Robert Scholes and Clifford Wulfman. Modernism in the Magazines: An Introduction. (New Haven: Yale University Press, 2010), 28.

${ }^{56}$ Candy Gunther Brown, The Word in the World: Evangelical Writing, Publishing, and Reading in America, 1789-1880. (Chapel Hill: University of North Carolina Press, 2004), 141.

57 James H. Moorehead, "The Millennium and the Media" in Communication and Change in American Religious History. Leonard I. Sweet, Ed., (Grand Rapids, MI: William B. Eerdmans Publishing Co. 1993), 227.

${ }^{58}$ Cited in Joan Jacobs Brumberg, Mission for Life: The Story of the Family of Adoniram Judson, the Dramatic Events of the First American Foreign Mission, and the Course of Evangelical Religion in the Nineteenth Century. (New York: Free Press, 1980), 68.
} 
established, non-denominational groups who had little in the way of other resources. Print fundamentally altered the way that evangelists worked.

In the aftermath of the Civil War there were two divergent Protestant responses to the issues associated with reconstructing the nation and the failure of mainline Protestantism to address the transformations occurring in American society. ${ }^{59}$ Most of the established denominations, along with liberal Protestants, shifted the focus of their religious fervor to the biblical transformation and renewal of the nation. Bolstered by the triumph of the Civil War, former abolitionist reformers shifted their efforts to a host of causes including poverty, prison reform, temperance, schooling, child labor, and peace. They promoted a "Social Gospel" of reform that fit well with political progressives, who deigned to reform and rebuild the nation. ${ }^{60}$

Another response came predominantly from denominational outliers, as well as new sects who pushed instead for an intimately personal transformation of the self, and spiritual redemption of the people of the world. These believers believed that salvation was imperative, for the millennium was neigh, and Jesus would return soon. Spurred on by stories of miracles, eyewitness accounts of divine healing, spiritual gifts, and personal testimonies, these Americans believed

\footnotetext{
${ }^{59}$ For more on the great divide in American Protestantism, see: Randall Balmer, The Making of Evangelicalism: From Revivalism to Politics and Beyond. (Waco, TX: Baylor University Press, 2010), 36-38; and James H. Moorhead, World Without End.

60 For more detailed analysis of the Social Gospel movement see: Ahlstrom, Sydney, A Religious History of the American People. (New Haven and London: Yale University Press, 1972), 785-804; and Ralph Luker, The Social Gospel in Black and White: American Racial Reform, 1885-1912. (Chapel Hill, NC: The University of North Carolina Press, 1991).
} 
they were living in the last days, and they sought tangible "signs" as "proof" that their convictions were accurate. More generally, there was a disillusionment with the established institutional churches, as they had not only failed to maintain the peace, but had arguably contributed to the War by adding a spiritual dimension to the stakes.

One of the most significant elements of these groups were their reliance on print to circulate their ideas. The leaders were often known for their publications, as the periodical offered a substitute for brick-and-mortar association. A premillennialist outlook fed their missionary impulse as they attempted to reach as many as possible before the return of Christ. Few were interested in reforming the country through the traditional channels of state policy or social work, but instead focused on healing the body and the soul. Their theology varied widely, but many emphasized the role of healing in the Christian faith, and they all desired to reform the universal church to return as much as possible to the early apostolic church. Finally, influenced by American individualism, democratization, and the aftershocks of the Civil War, these groups found authority in direct personal revelation rather than church or biblical authority. In this regard, they are all quintessentially American religious expressions as well.

The first of these "new spiritualists" to emerge were the Mormons. Deemed as "American as apple pie,"61 Mormonism was an indigenous American

${ }^{61}$ David E. Campbell, John Clifford Green and J. Quin Monson. Seeking the Promised Land: Mormons and American Politics. (New York: Cambridge University Press, 2014), 256. Historian Ernest Tuveson also argues that Mormonism represents "the most characteristically 'American' 
religion and hailed from the teachings of Joseph Smith (1805-1844), an American religious leader and founder of the movement. ${ }^{62}$ Smith claimed to have visions involving the translation of an ancient Judeo-Christian history of the Americas on golden plates given to him by an angel. The English translations of these plates became The Book of Mormon, which Smith published in 1830. That same year he organized the Church of Christ, whose members were called "latter day saints," and set about revising the Bible, which he believed no longer reflected the original text. ${ }^{63}$ Mormons considered themselves true Christians, but were distinctive in teachings, practice, and ritual in ways that put America at the center of their belief system. Writing on the "quintessential Americanness" of Mormons, historian Patricia Limerick asserts, "Faith in progress, commitment to hard work, devotion to the family, careful attention to material prosperity-in all these qualities, Mormons could not have been more American." ${ }^{64}$ After all, Smith's revelation occurred in upstate New York, he taught that Jesus Christ visited America after his resurrection, and that the Garden of Eden and the site of the "new Jerusalem" and Christ's second coming was located in western Missouri. ${ }^{65}$ As historians like Gordon Wood note, Mormon theology echoed the rising cultural

religious doctrine ever set forth." See: Ernest Tuveson, Redeemer Nation: The Idea of America's Millennial Role ([1968]; rpt., Chicago: University of Chicago Press, 1980), 185.

62 Henry K. Carroll, Report on the Statistics of Churches in the U.S. in the Eleventh Census: 1890. Vol. IX. Eleventh Census: 1890. (Washington, D.C.: Government Printing Office, 1894), 420.

${ }^{63}$ Richard L. Bushman and Jed Woodworth. Joseph Smith: Rough Stone Rolling. (New York: Alfred A. Knopf, 2005), 84-88, 133.

${ }^{64}$ Patricia Nelson Limerick, The Legacy of Conquest: The Unbroken Past of the American West (New York: W. W. Norton \& Company, 1987), 286.

${ }^{65}$ Bushman and Woodworth, Joseph Smith: Rough Stone Rolling, 84-88, 122-123. 
nationalism of the republic, and their organization hearkened back to a rural patriarchal pastoralism in a country ruled by the uncertainties of the market. ${ }^{66}$ Yet during the nineteenth century, many Christians found the teachings, claims, and practices of Smith and his followers to be heretical. ${ }^{67}$ Killed by an angry mob in 1844, Smith was succeeded by Brigham Young (1801-1877), who took the movement west, where he founded it in Salt Lake City and where he served as the first Governor of the Utah territory. Here the Mormons thrived; by 1890 the LDS church reported 188,263 members, of which roughly $62 \%$ lived in Utah. ${ }^{68}$ Adventists best embodied the premillennialist advance of the nineteenth century. As another wholly indigenous American faith, the Seventh Day Adventists benefitted from the spiritual eclecticism and religious populism of the early republic. ${ }^{69}$ Seventh Day Adventist emerged from the Millerite movement that originated in the New York burned over district during the Second Great Awakening. William Miller (1782-1849) was a former Deist, a veteran of the War of 1812, and farmer from New York, before becoming the founder of Millerism. He claimed that through a careful reading of the Bible, he had determined that

\footnotetext{
${ }^{66}$ Gordon Wood, "Evangelical America and Early Mormonism," New York History 61 (1980): 363; and Benjamin E. Park, "Early Mormon Patriarchy and the Paradoxes of Democratic Religiosity in Jacksonian America," American Nineteenth Century History 14, no. 2, (2013): 186-189.

${ }^{67}$ Leonard J. Arrington and Davis Bitton, The Mormon Experience: A History of the Latter-Day Saints. (New York: Knopf, 1979), 44-64.

${ }^{68}$ Henry K. Carroll, Report on the Statistics of Churches in the U.S. in the Eleventh Census: 1890. Vol. IX. Eleventh Census: 1890. (Washington, D.C.: Government Printing Office, 1894), 423.

69 Susan Juster, Doomsayers: Anglo-American Prophecy in the Age of Revolution. (Philadelphia: University of Pennsylvania Press, 2003), 16.
} 
the world would end with the return of Christ on October 22nd, $1844 .{ }^{70}$

Approximately 50,000 to 200,000 adherents took part in what became known as "America's most significant millenarian expression" when they waited patiently for Miller's prophesy to be fulfilled. ${ }^{71}$ When this failed to happen, most left the group, but the few that remained formed a conference in 1845 and the largest group that persisted became known as the Seventh Day Adventists. Adventists connected together through the publication of James Springer White's (1821-1881) periodical The Advent Review and Sabbath Herald. White, like many other leaders of this era, wrote prolifically. His wife, Ellen Gould White, who arguably had the biggest impact on the survival and growth of the sect into a legitimate denomination, claimed that Christ failed to return due to Miller's failure to keep the Sabbath. ${ }^{72}$ Formally established in 1863 , the Seventh Day Adventist Church saw its membership rise to 28,991 communicants by 1880 through missionary

\footnotetext{
${ }^{70}$ Carroll, Report on the Statistics of Churches in the U.S. in the Eleventh Census: 1890, 119.

${ }^{71}$ David L. Rowe, "Millerites, A Shadow Portrait," in Ronald L. Numbers and Jonathan M. Butler, eds., The Disappointed: Millerism and Millenarianism in the Nineteenth Century (Bloomington: Indiana University Press, 1987), 15. Exact numbers are unclear but conservative estimates begin at 50,000. See Benjamin McArthur, "Millennial Fevers". Reviews in American History 24, no. 3 (1996): 371.

72 Theodore N. Levterov, The Development of the Seventh-Day Adventist Understanding of Ellen G. White's Prophetic Gift: 1844-1889. American University Studies - Series VII: Theology and Religion, Vol. 347. (New York : Peter Lang, 2015); and Jonathan M. Butler, "Prophecy, Gender, and Culture: Ellen Gould Harmon [White] and the Roots of Seventh-Day Adventism". Religion and American Culture 1, no. 1 (1991): 3.
} 
and revival work. ${ }^{73}$ The church held to strict dietary restrictions, emphasizing vegetarianism and abstention from tobacco and alcohol. ${ }^{74}$

The Jehovah's Witnesses emerged in the post-war years and combined premillennialist eschatology with an intense focus on evangelism. The group grew out of the Bible Student Movement, which held to the millennialistrestorationist teachings of Charles Taze Russell (1852-1916). In 1879 Russell began publishing Zion's Watch Tower and Herald of Christ's Presence, a monthly periodical that would eventually become known as simply "The Watchtower." Russell and his followers challenged many of the traditionally accepted theological Christian beliefs including immortality of the soul, hellfire, predestination, the fleshly return of Jesus Christ, the Trinity, and the burning up of the world. ${ }^{75}$ Together with his colleague William Henley Conely, Russell cofounded Zion's Watch Tower Tract Society in 1881. Beginning in the early 1880s, supporters from different denominational backgrounds gathered in bible studies to discuss Russell's teachings. Russell, too, wrote constantly, producing articles, books, tracts, pamphlets and sermons, becoming most famous for his six-volume bible study series Millennial Dawn, which went on to sell more than 20 million copies in multiple languages during his lifetime. The Tract Society grew through

\footnotetext{
${ }^{73}$ Henry K. Carroll, Report on the Statistics of Churches in the U.S. in the Eleventh Census: 1890. Vol. IX. Eleventh Census: 1890. (Washington, D.C.: Government Printing Office, 1894), 128.

74 Malcolm Bull and Keith Lockhart. Seeking a Sanctuary: Seventh-Day Adventism and the American Dream. (Bloomington: Indiana University Press, 2007), 164.

75 James A. Beckford, The Trumpet of Prophecy: A Sociological Study of Jehovah's Witnesses. (New York: Wiley, 1975), 2.
} 
the extensive publication of tracts and bibles distributed by traveling preachers, itinerant evangelists, and colporteurs throughout the country. After his death in 1916 the Bible Student Movement fractured, with those who retained contact with the Watch Tower Tract Society re-branding themselves as the Jehovah's Witnesses in $1931 .{ }^{76}$

The emergence of Christian Science in the late nineteenth century exemplified a Protestant attempt to reconcile faith and science. ${ }^{77}$ Mary Baker Eddy (1821-1910) founded and developed the ideas behind the new religious movement in her book, Science and Health with Key to the Scriptures in 1875. In it, Eddy expounded on her ideas about the "science" of "primitive Christianity" and the last 100 pages of her book contained printed testimonies of people that claimed to have been healed through her work. ${ }^{78}$ For Eddy, the material world was an illusion and the only reality was the spiritual:

There is no life, truth, intelligence, nor substance in matter. All is infinite Mind and its infinite manifestation, for God is All in all. Spirit is immortal Truth; matter is mortal error. Spirit is the real and eternal; matter is the unreal and temporal. Spirit is God, and man is His image and likeness; hence, man is spiritual and not material. ${ }^{79}$

\footnotetext{
${ }^{76}$ For more on the Jehovah's Witnesses see: M. James Penton, Apocalypse Delayed: The Story of Jehovah's Witnesses. (Toronto: University of Toronto Press, 2015); Barbara Grizzuti Harrison, Visions of Glory: A History and a Memory of Jehovah's Witnesses. (New York: Simon and Schuster, 1978); James A. Beckford, The Trumpet of Prophecy: A Sociological Study of Jehovah's Witnesses. (New York: Wiley, 1975).

${ }^{77}$ Stephen Gottschalk, The Emergence of Christian Science in American Religious Life. (Berkeley: University of California Press, 1973), 18-26.

${ }^{78}$ Eddy's beliefs were strongly influenced by Spiritualism, metaphysics, and philosophical idealism. She wanted to restore the healing works of the early apostolic church to the present by focusing on spiritual healing through the power of prayer. See Robert Peel, Mary Baker Eddy: The Years of Authority. (New York: Holt, Rinehart and Winston, 1977).

${ }^{79}$ Mary Baker Eddy, Science and Health, with Key to the Scriptures. One hundred and eighty-
} 
Like the other groups, Eddy mastered the art of religious marketing and print in order to spread her ideas. In 1879 she founded The Church of Christ, Scientist and in 1898 she founded the Christian Science Publishing Society, which handled the Church's publications. Of these, The Christian Science Monitor, established in 1908 , still enjoys a print circulation of over 75,000 , as well as a robust online reach. ${ }^{80}$

Of all these groups, the nineteenth-century Holiness movement best embodies the religious zeitgeist of the era. Due to its relative lack of institutional structure and formal theology, defining the movement offers problems. Holiness theology was characterized by a doctrine of sanctification that emphasized the idea of "perfectionism" or "entire sanctification." ${ }^{11}$ This doctrine imbued religious adherents with the idea that perfection was possible in all aspects of life, whether it be individuals, religion, or society. Outward expressions of sanctification proved that one was exercising their free will to defeat sin. Entire sanctification was the

third edition. (Boston, Mass: Joseph Armstrong C.S.D. 1900), 464.

${ }^{80}$ Rick Edmonds, "Christian Science Monitor sees traffic, revenues rising after 3 years of Web-first strategy" Poynter. May 2, 2012, accessed November 12, 2015.

http://www.poynter.org/2012/christian-science-monitor-sees-traffic-revenues-rising-after-3-yearsof-web-first-strategy/171833/

81 The concept of perfectionism was the theological innovation of Charles G. Finney, one of the most famous evangelists of the Second Great Awakening, who preached that "after a true experience of conversion a person could achieve the coveted state of Christian perfection or sanctification by simply exercising free will." See: Vinson Synan, The Holiness-Pentecostal Tradition,15. Historical studies tracing the theological roots of the American Holiness movement include: D. W. Bebbington, Holiness in Nineteenth-Century England. (Carlisle: Paternoster, 2000); Nancy Hardesty, Faith Cure: Divine Healing in the Holiness and Pentecostal Movements. (Peabody, Mass: Hendrickson Publishers, 2003); Charles Edwin Jones, Perfectionist Persuasion: The Holiness Movement and American Methodism, 1867-1936. (Metuchen, N.J.: Scarecrow Press, 1974); and Timothy Lawrence Smith and W. T. Purkiser. Called Unto Holiness; The Story of the Nazarenes. (Kansas City, Mo: Nazarene Pub. House, 1962). 
belief that after conversion, one could reach a point of perfection in motives and desires through the ongoing sanctification process. The doctrine of perfectionism originated with the Methodist John Wesley (1703-1791), who articulated the process of Christian perfection in his Plain Account of Christian Perfection (1738), arguing that "all of our preachers should make a point of preaching Christian perfection constantly, strongly, and explicitly." 82 The "movement" could first be discerned as a revival beginning in $1866,{ }^{83}$ and included Protestant denominations, parachurch organizations, and many localized associations ranging from nondenominational storefront churches to prayer groups that emphasized these beliefs as their central doctrine.

If the origin of the formal, theology of the holiness movement lay in the $18^{\text {th }}$ century with Wesley, it was embedded within a larger and different institutional structure. Only in the decades before the Civil War did its theological precepts emerge as a separate movement. It appears first in the activities of Phoebe Palmer, (1807-1874) and her husband, Walter Palmer, both devout leaders within the American Methodist Church. In the 1830s, she had organized a home worship group for women, which she called "Tuesday Meetings for the promotion of Holiness." In 1843 she summarized - and formalized - the general ideas of the theological innovation in her book, The Way of Holiness with Notes

\footnotetext{
82 John Wesley, A Plain Account of Christian Perfection. (New York: G. Lane and P. P. Sandford. 1844 ed., originally 1738), 57.

${ }^{83}$ Robert R. Owens, Speak to the Rock: The Azusa Street Revival, Its Roots and Its Message. (Lanham, MA: University Press of America, 1998), 32.
} 
By The Way. In it, she outlined her theology of Holiness, or "entire sanctification," as a second grace after justification, and explained how Christians might obtain a state of perfection through holy living. Palmer's teaching caught on like wildfire and throughout the 1840s there was "a veritable flood of perfectionistic teaching in the Methodist Church." ${ }^{84}$ An international evangelist, she, with her husband, launched a periodical of the movement, The Guide to Holiness in 1864. The Palmers' teachings spread through regional localized groups like prayer meetings. The movement combined these perfectionist teachings with an emphasis on outward expressions of sanctification, and since adherents were not bound by the prevailing social codes of their mainstream protestant brethren, their meetings were not infrequently racially integrated, loud, and expressive. ${ }^{85}$

In July, 1867, a group of 13 Methodist ministers formed "The National Camp Meeting Association for the Promotion of Holiness," with the express purpose of creating a an avenue for religious worship "irrespective of denominational ties" for those "who feel themselves comparatively isolated in their profession of holiness." 86 The interdenominational National Holiness Association spread by way of revivals, camp meetings, and an impressive publishing campaign throughout the South during the period between 1860 and

\footnotetext{
${ }^{84}$ Synan, The Holiness-Pentecostal Movement in the United States, 28.

${ }^{85}$ Randall J. Stephens, The Fire Spreads: Holiness and Pentecostalism in the American South. (Cambridge, Mass: Harvard University Press, 2008), 9.

${ }^{86}$ Synan, The Holiness-Pentecostal Tradition, 25.
} 
1885 , and assumed nationwide proportions by the late $1880 \mathrm{~s} .{ }^{87}$ From 1867 to 1883 a grand total of fifty-two "national camps" were held, with some boasting attendance of over $20,000.88$

During the post-war period the movement gained even more prominence in mainstream protestant denominations, which began to view these movements as disruptive and doctrinally dangerous. Controversy arose in the 1880s when many of the Holiness preachers began to adopt a "come-outism" position that preached an anti-denominational message. The call to leave traditional churches offended the Methodists who had supported the Holiness movement throughout the period. Yet as historian Allan Anderson asserts, the movement was "a reaction against liberalism and formalism in established Protestant churches as a whole, and not just the Methodist Church." ${ }^{89}$ The anti-sectarianism of the Holiness adherents was a reaction against a perceived "coldness" of the main denominational churches who emphasized "formality" over spiritual growth. ${ }^{90}$ By the 1890s the Methodist Church had lost any semblance of control over the Holiness Movement, and the Holiness Movement leadership had lost control of its own members. In the midst of this declension, many individual believers sought direction and authority from God in order to bypass the church.

\footnotetext{
87 Ibid, 29.

88 lbid, 26.

${ }^{89}$ Allan Anderson, Spreading Fires: The Missionary Nature of Early Pentecostalism. (London, Great Britain: SCM Press, 2007), 21.

90 Synan, The Holiness-Pentecostal Tradition, 36.
} 
Especially given the informality of the theology and the looseness of institutional structures, the movement can be understood in part by examining some of its advocates and practitioners. Spiritual healing was a particularly attractive element within the Holiness movement. Holiness ministers and evangelists often focused on divine healing, and "healing centers" were a common feature of the movement. Some of the most widely renowned Holiness members were faith healers, and their notoriety often led to celebrity status within the movement. John Alexander Dowie (1847-1907) was one such figure whose notoriety gained him thousands of followers. ${ }^{91}$ Dowie was a curious and sensational figure who founded the city of Zion, Illinois, as well as the Christian Catholic Apostolic Church. Historian David Harrell, who studies the healing and charismatic revivals of the period, correctly identifies Dowie as "the father of healing revivalism in America."92 Dowie's theology was thoroughly restorationist and he held to a dispensational premillennialist eschatology. He desired to

\footnotetext{
91 Dowie remains an intriguing figure not only within the Holiness movement, but also within the larger religious climate of the nineteenth-century United States. Born in Edinburgh, Scotland in 1847, he moved with his parents to Adelaide, South Australia at the age of 13, where he succeeded mostly in business. He returned to Scotland to study theology at the University of Edinburgh at the age of 21. Afterwards, he returned to Australia and received ordination as a Congregational pastor. Two years later, he took a position of another Congregational church in Sydney, New South Wales, and married his full cousin, Jane Dowie, in 1876. During the 1880s, Dowie became interested in divine healing, and in 1882 he moved to Melbourne Australia where he established the International Divine Healing Association. In 1888 he left for a healing conference in England, but after arriving in San Francisco and successfully preaching throughout California, he decided to stay in the U.S. He eventually made it to the Chicago area where in 1901 he established Zion City in Lake County, Illinois, as a sort of premillennialist commune and place of healing. He published a weekly healing periodical, Leaves of Healing, containing the testimonies of those healed. See Cook, Philip L. Zion City, Illinois: Twentieth-Century Utopia. (Syracuse, N.Y.: Syracuse University Press, 1996), 6, 8-10.

92 David Edwin Harrell, All Things Are Possible: The Healing \& Charismatic Revivals in Modern America. (Bloomington: Indiana University Press, 1975), 13.
} 
restore the church to its pristine and uncorrupted status - as he perceived it was in the days of the apostles - including the restoration of spiritual gifts and divine healing. Dowie's Zion City was a theocratic utopia in which devotees attempted to live as close as possible to the early church while awaiting the imminent return of Jesus Christ. ${ }^{93}$ Zion City was just outside of Chicago, yet another metropolis of the West that featured all the promises and failures of unbridled capitalism at the beginning of the twentieth century.

Dowie embodied many of the defining elements of new spiritualism. He believed in the continuation of the charismatic gifts; that is, unlike cessationists, who believed that the "gifts of the Spirit" as described in the biblical book of Acts had ended with the closure of the canon, Dowie believed that they continued to the present. ${ }^{94}$ This provided the foundation for his argument that sickness was a manifestation of sinfulness in the believer's life, and that it could be cured through prayer and repentance. Like many other sect leaders of the day, Dowie harnessed the power of mass communication to stake his space in the American religious sphere. He established Zion Printing and Publishing House, which in addition to Leaves of Healing printed a monthly theological journal $A$ Voice From Zion, and a biweekly secular news publication entitled The Coming City (later the Zion Banner). ${ }^{95}$

\footnotetext{
${ }^{93}$ See Philip L. Cook, Zion City, Illinois: Twentieth-Century Utopia. (Syracuse, N.Y.: Syracuse University Press, 1996).

94 Edith L. Blumhofer, The Assemblies of God: A Chapter in the Story of American Pentecostalism. (Springfield, MO: Gospel Publishing House, 1989), 33.

${ }^{95}$ Grant Wacker, "Marching to Zion: Religion in a Modern Utopian Community". Church History
} 
Dowie understood the power of timing and the impact of symbolism and aesthetics. He opened his first official makeshift "tabernacle" adjacent to the World's Fair in Chicago in 1893, ensuring ample coverage in the press. ${ }^{96}$ His message stood in direct contrast to that of the medical professionals presenting at the World's Fair. When he preached, onlookers were presented with a fivefoot-four, 200 pound man with a huge full white beard and bald head. Dowie dressed in resplendently embroidered long flowing robes and a gargantuan priestly hat. People often referred to him as "Doctor" Alexander Dowie, although he held no such medical degree. ${ }^{97}$ Dowie's fame reached its zenith in 1901 when he proclaimed himself "Elijah the Restorer" and was subsequently denounced by religious leaders across the country. Dowie's celebrity status in the circuit of religious print networks and secular newspapers attracted thousands to Zion City and the healing homes in Chicago, inspiring many who would later join the early Pentecostal movement.

One of these visitors, an itinerant evangelist by the name of Charles Parham (1873-1929), would become known as the theological father of modern Pentecostalism. ${ }^{98}$ Parham's life was emblematic of the dislocation and turbulence

54, no. 4 (1985): 500, accessed June $10^{\text {th }} 2015$. http://www.jstor.org/stable/3166516.

${ }^{96}$ Cook, Zion City, Illinois: Twentieth-Century Utopia, 11.

97 Ibid; Craig Borlase quotes Frank Sandford, another founder and leader of an apocalyptic Christian sect called "Shiloh" in Maine as stating "Dr. Dowie of Chicago prays with or for as many as 70,000 sick people a year, and thousands of the most astounding and remarkable miracles have taken place" in William Seymour: A Biography. (Lake Mary, FL: Charisma House, 2006), 61.

98 Parham visited Dowie's healing homes in Chicago in 1900. See Sarah E. Parham, The Life of Charles F. Parham, Founder of the Apostolic Faith Movement. (Joplin, MO: Tri-State Print. Co, 1930), 9. 
of the times. Born in lowa but raised in Kansas after his family migrated west. He experienced many of the trials of frontier life, as he spent his childhood years ill and crippled from the effects of rheumatic fever. The idea of divine healing was prominent in many Holiness churches, and Parham's struggles with illnesses for most of his life drove him toward a theology that emphasized divine healing. He studied to be a physician at Southwestern Kansas College at the age of sixteen, but left due to poor health, which he later claimed was God's judgement for not entering the ministry. ${ }^{99}$ Parham claimed to have experienced divine healing after a near-death experience related to his rheumatism in which God miraculously healed him. He claimed that this experience was the prompt for his career as an independent evangelist. ${ }^{100}$

Parham adopted many of the teachings of the Holiness movement, but believed that true Christianity - what he called "the Apostolic Faith" - could not be found in denominational churches. ${ }^{101}$ In his book, $A$ Voice Crying in the Wilderness (1901) Parham expressed his frustration with the sectarianism of the day:

Finding the confines of a pastorate, and feeling the narrowness of sectarian churchism, I was often in conflict with the higher authorities, which eventually resulted in open rupture; and I left denominationalism forever, though suffering bitter persecution at the hands of the church, who seemed determined if possible my soul should never find rest in this

\footnotetext{
${ }_{99}$ Parham, The Life of Charles F. Parham, 9.

100 lbid.

${ }^{101}$ Blumhofer, Restoring the Faith, 45.
} 
world or the world to come. Oh the narrowness of many who call themselves the Lord's own! ${ }^{102}$

Parham's physical health was perhaps the singular driving factor in his ministry. He married on New Year's Eve, 1896, and his first son was born in September, 1897. Despite the happy life events, Parham's health once again deteriorated. He was diagnosed with heart disease, and his son became sick with an undiagnosed illness. As a reaction to these unfortunate events, the Parhams moved in 1898 to Topeka Kansas and established a "Divine Healing Home" which provided "home-like comforts for those who were seeking healing, while we prayed for their spiritual needs as well as their bodies." 103 The Parhams also published a paper, The Apostolic Faith twice a month for a small subscription. ${ }^{104}$ Parham traveled throughout the US to other healing communities and Holiness groups in order to "know more fully the latest truths restored by later day movements." 105 He opened a communal Bible School in Topeka Kansas in mid-October 1900 , for the stated purposes of training male and female missionaries for evangelizing before the "end of the age." 106 The group of approximately 40 students lived communally, sharing all their belongings and money, and although hailing from diverse protestant backgrounds, they

\footnotetext{
102 Parham, The Life of Charles F. Parham, 23.

103 lbid, 39.

104 The paper acted as advertising for the healing home, by recounting the miracles taking place along with the sermons and teaching of Parham. See Owens, Speak to the Rock, 51.

105 Parham, The Life of Charles F. Parham, 48.

106 Ibid, 51.
} 
constituted a group that was on the radical fringe of the larger Holiness

movement. ${ }^{107}$

It was at the Bible School in Topeka that Parham formulated the eventual doctrinal cornerstone of the Pentecostal movement. Parham expanded on the "second blessing" doctrine, ${ }^{108}$ which held that there were three steps in the salvation process: The first step was salvation, the second was Holy Spirit Baptism, and the third was sanctification. Parham desired to find some sort of "proof" that one had experienced the baptism of the Holy Ghost. In his autobiography he explained:

We had reached in our studies a problem. What about the 2nd chapter of Acts? I had felt for years that any missionary going to the foreign field should preach in the language of the natives. That if God had ever equipped His ministers in that way He could do it today. That if Balaam's mule could stop in the middle of the road and give the first preacher that went out for money a 'bawling out' in Arabic that anybody today ought to be able to preach in any language of the world if they had horse sense enough to let God use their tongue and throat. ${ }^{109}$

Parham sent the students searching the Bible for evidence of the baptism of the Holy Ghost. When they next convened, they were in unanimous agreement that the "indisputable proof on each occasion was, that they spake with other tongues." ${ }^{110}$ The assertion that Holy Spirit Baptism was evidenced by

\footnotetext{
107 Goff, Fields White Unto Harvest, 69.

108 The "Second Blessing" is also known as "entire sanctification," "Christian holiness," a "second work of grace," "baptism of fire," and "Baptism of the Holy Spirit," among others.

109 See Charles Fox Parham, "The Story of the Origin of the Original Apostolic or Pentecostal Movement" in The Life of Charles F. Parham; Founder of the Apostolic Faith Movement, 52.

110 Ibid, 52.
} 
speaking in tongues would become the main theological contribution of Charles Parham to the origin of Pentecostalism. ${ }^{111}$

On the first night of the New Year, ${ }^{112}$ the 40 or so Bible School students and an additional 75 participants gathered for a "Watch Night service." ${ }^{113}$ One of the students named Agnes Ozman (1870-1937) asked for hands to be laid on her, and when Parham acquiesced, "a halo seemed to surround her head and face, and she began speaking in the Chinese language, and was unable to speak English for three days. When she tried to write in English to tell us of her experience she wrote the Chinese, copies of which we still have in newspapers printed at that time." 114 This began a multi-day period of revival at the college, with others claiming to speak in foreign languages and still others claiming to understand them and translate. Parham claimed to receive the gift of tongues as well, being first given the "Sweedish tongue" which morphed into other languages throughout the night. ${ }^{115}$ The "outpouring at Topeka" lasted two more nights and three days, and news of the occurrences spread through word-of-mouth and the holiness periodical circuit to contribute to an already growing atmosphere of

\footnotetext{
${ }^{111}$ For more on the theology of Holy Ghost Baptism and Parham's theological journey, see: James R. Goff, Fields White Unto Harvest; Douglas Gordon Jacobsen, Thinking in the Spirit: Theologies of the Early Pentecostal Movement; and Vinson Synan, The Holiness-Pentecostal Tradition: Charismatic Movements in the Twentieth Century.

112 The precise date is in question. Parham's wife puts it as the early hours of Jan 1st, while Ozman stated that it was 11:00pm on Jan 1st. See: Craig Borlase, William Seymour: A Biography; Sarah E. Parham (Thistle-Thwaite), The Life of Charles F. Parham; Founder of the Apostolic Faith Movement. (Baxter Springs, KS: Apostolic Faith Church, 1930), 52-53.

113 Parham, The Life of Charles F. Parham, 52.

114 lbid, 52-53.

115 Ibid, 54.
} 
anticipation for revival around the country. Parham believed that this revival would usher in a new era of Apostolic Christianity, in which Christians returned to living the way that the disciples had lived in the time of Christ.

In linking speaking with tongues with baptism of the Holy Spirit, Parham laid the theological framework for the Pentecostal movement. As scholar Robert R. Owens points out, Parham developed the vocabulary of the movement, coining all three of the names used to describe modern Pentecostalism including the Latter Rain Movement, Pentecostal Movement, and the Apostolic Faith. ${ }^{116}$ Parham's theological contributions notwithstanding, the Topeka outpouring failed to manifest into a movement. Just so, the Topeka revival also lacked many of the critical attributes that made the revival at Azusa Street successful.

To understand the success of the later Azusa Street Revival that launched the modern Pentecostal movement one must understand the relative failure of Topeka. Topeka lacked several crucial elements that defined and solidified the later Pentecostal movement. Charles Parham reflected the religious environment of the time that gave rise to Pentecostal theology, but he also embodied the social limitations of the Holiness movement. His student, William Seymour, embodied the new values, ideas, and aspirations of a new generation of Christians would advance a radically apocalyptic evangelism for the twentieth century.

${ }^{116}$ Owens, Speak to the Rock, 51. 
First, the location of the revival in Topeka was not immediately conducive for garnering attention. Topeka was in the middle of the country, but it was a relatively small city with little traffic. Topeka had a total population of 33,608 in 1900, while Los Angeles, the site of the later Azusa Street revival, held a population of $102,479 .{ }^{117}$ The press in Topeka simply didn't have the same reach as the Los Angeles papers.

Second, the Topeka revival was comprised entirely of white students, and therefore limited its reach to people of color as well as anyone who might have been curious of a multiracial audience. Parham's Bethel Bible School only held 34 students, and the congregation of Parham's Bethel Healing Home where he preached was no more than $100 .{ }^{118}$ As Parham's sister-in-law, Lilian Thistlethwaite wrote, "There were only white persons present at the first Pentecostal shower. No colored people were ever in the school." ${ }^{119}$ Nor were they invited. Parham's views on racial hierarchies were reflective of the era, and he worked them into his theology as well. ${ }^{120}$ His disgust over interracial worship thus limited the impact of the revival.

\footnotetext{
117 U.S. Census Bureau, 1960 U.S. Census of Population, Number of Inhabitants: Kansas (PC(1)18A); 1980 Census of Population, Number of Inhabitants: Kansas (PC80-1-A-18); 1990 Census of Population and Housing, Population and Housing Counts (CPH-2-1 and CPH-L-157). In "Kansas Population Data," Kansas Statistical Abstract 2014, Institute for Policy and Social Research, (September 2015), 67, accessed April $9^{\text {th }}, 2016$. www.ipsr.ku.edu/ksdata/ksah; and "Historical Census Populations of Counties and Incorporated Cities in California, 1850-2010," California Department of Finance, 2013, accessed April 9 ${ }^{\text {th }}, 2016$.

http://www.dof.ca.gov/research/demographic/state_census_data_center/historical_census_18502010/view.php.

118 Goff, Fields White Unto Harvest, 63-64.

119 Parham, The Life of Charles Parham, 63.

${ }^{120}$ Parham justified his views against miscegenation by arguing that the great "sin" during Noah's time was because men were intermixing and creating "half-breeds." See, Charles Parham, $A$
} 
Third, although Parham explicitly preached that speaking in tongues served the purpose of literally gifting Christians with foreign languages that they may preach the gospel in foreign lands, this initial revival did not result in much missionary output, either domestically or internationally. ${ }^{121}$ Parham's main contribution to the movement lies in his development of glossolalia as the "initial evidence" of spiritual baptism, and specifically xenoglossia, ${ }^{122}$ which is "speaking a known foreign language without having gained a prior knowledge of that tongue." 123 The homogeneity of the Topeka group presented challenges to the claims of xenoglossia, since no one was present who could benefit from hearing a foreign language. Parham intended to use the revival as a starting point for mission training, so that they might equip missionaries to go to foreign lands with this new gift of "mission tongues." However, the isolation and homogeneity of the group made proving xenoglossia very difficult. No one was there who could confirm that the languages being spoken were in fact "real." Parham and some of the students embarked on a revival tour of the Mid-west to promote this new theology, but the public remained dubious. The Topeka Daily Capital provided a skeptical report: "Some of Miss Auswin's writing, which she claimed to be inspired, was submitted to a Chinaman here in Topeka with the honest intention of seeing if he could translate it. The Celestial threw up his hand and said: 'Me no

\footnotetext{
Voice Crying in the Wilderness. (Kansas City, MO: By the author, 1902; reprint ed., Joplin, Missouri: Joplin Printing Co., 1944), 84-85.

${ }^{121}$ Allan Anderson, Spreading Fires: The Missionary Nature of Early Pentecostalism, 41.

122 Defined as the ability to speak a language with which the person are unfamiliar.

${ }^{123}$ Goff, Fields White Unto Harvest, 15.
} 
understand. Takee to Jap."'124 Thus the Topeka revival remained highly localized, failing to catalyze into a movement.

Finally, like so many other sects in this period, the Topeka revival was centered on the personality of Charles Parham. Thus when he fell, the group disintegrated. The Parhams experienced a number of personal tragedies and difficulties, including the death of their child shortly after the 1901 revival in Topeka, the defections of some of Parham's students after the initial revival, as well as later scandalous accusations of sodomy. ${ }^{125}$ Yet one student named William Seymour found Parham's teachings particularly impressive. Seymour attended Parham's "Bible Training School" while living in Houston, TX in 1905. As a black man, Seymour was barred from technically attending Parham's Bible School, as Texas segregation laws made it illegal, so Parham allowed Seymour to sit outside the door of the classroom and listen to the lectures. ${ }^{126}$ Seymour was barred from tarrying at the alter with whites, and thus was unable to fully participate in the worship process. Although Parham thought Seymour good

124 Topeka Daily Capital, January 6, 1901. 2.

${ }^{125}$ Parham went to Zion City, IL in September of 1906. Alexander Dowie had by this time been accused of all sort of misconduct including polygamy, misappropriation of funds, etc. He also had a stroke in 1905, leaving him physically weak as well. His former disciple, Wilbur Glenn Voliva, was posturing for control. Parham stepped into this power vacuum and stared a war of control for the remnants of Zion. (That July a judge had ruled that Zion's industries, controlled by Dowie, fall under control of a receivership. John Craig Hadley was named receiver and elections were held to determine the local overseer. Dowie was handily defeated.) A detailed account of the throw down between Voliva and Parham can be read in Goff Jr., Fields White Unto Harvest: Charles F. Parham and the Missionary Origins of Pentecostalism, 120-144. In July 1907 Parham was arrested for sodomy in Texas, creating the first great scandal of the young Pentecostal movement.

126 Texas laws were not the only reason Seymour was not allowed in the class, as Parham himself held some noxious racial views. Like many during this period he advocated spiritual, but not social equality between the races. 
enough to help him preach, Seymour was only able to preach side by side with Parham to segregated crowds in black neighborhoods. Seymour would later strike out on his own and take the message of tongues to Los Angeles.

Seymour's early life reflects the destabilization that characterized the postwar period. William Joseph Seymour was born on May $2^{\text {nd }}, 1870$ in Centerville, Louisiana. His parents were former slaves, and like many others in their position, the Seymours returned to their former plantation to work as laborers after the war. ${ }^{127}$ The Reconstruction period in Louisiana was an especially troubling time for free blacks, as racial tensions and economic hardships frequently resulted in violence against African Americans. ${ }^{128}$ Despite these hardships, at the age of 21 Seymour left and traveled north.

Seymour's twenties are emblematic of the peripatetic lifestyle of many young African-American men during this period. For ten years after leaving Louisiana, Seymour floated throughout the south and Midwest, and his life and movements are not always clear. Between 1891 and 1895 Seymour appears to

\footnotetext{
${ }^{127}$ While his parents had been born into slavery, his father took advantage of freedom and enlisted in the US Union Army, and served three years as a soldier in the $93^{\text {rd }}$ Regiment Infantry, United States Colored Troops, one of the first all-black regiments of the United States Army during the Civil War. See, Larry E. Martin, The Life and Ministry of William J. Seymour: And a History of the Azusa Street Revival. Joplin, MO: Christian Life Books, 1999. 50. See also: Historical Data Systems, comp... American Civil War Regiments [Database Online]. Provo, UT, USA: Ancestry.com Operations Inc, 1999. The $93^{\text {rd }}$ Regiment was initially the $25^{\text {th }}$ Regiment. The unit was organized on November $21^{\text {st }}, 1863$ and the name was changed in April, 1864. The unit was disbanded in April, 1866.

${ }^{128}$ Rayford Whittingham Logan, The Negro and the Post-War World, A Primer. (Washington, D.C.: Minorities Publishers, 1945); Joel Williamson, The Crucible of Race: Black-White Relations in the American South Since Emancipation (New York: Oxford University Press, 1984); LeeAnna Keith, The Colfax Massacre: The Untold Story of Black Power, White Terror, and the Death of Reconstruction. (Oxford: Oxford University Press, 2008).
} 
have lived and worked as a waiter in Memphis, St. Louis, and Indianapolis. ${ }^{129}$ Like many other young African American men of this era, Seymour was in a position to take advantage of the freedom that came with post-Reconstruction America. Racial tensions in the South pushed these men to move north, and in doing so many were able to travel and see more of the country than any other demographic group. ${ }^{130}$

Seymour's lack of a geographical home reflects his lack of a spiritual or religious home as well. ${ }^{131}$ His religious life prior to 1906 is almost as obscure as his constant movement, but it can be divided into three clear phases that compose a religious trajectory that ends at Azusa. Seymour began his search for a spiritual home by attending mainstream denominations that had interracial or all-black congregations. ${ }^{132}$ At the age of twenty-five, Seymour joined the Simpson

\footnotetext{
129 TN 1891 Voters List. William Seymour, Shelby Co., TN. District 9 - male voters. Pg. 132. Jackson, Ron V., Accelerated Indexing Systems, comp. Tennessee Census, 1810-91 [database on-line]. Provo, UT, USA: Ancestry.com Operations Inc, 1999. See also, Larry E. Martin, The Life and Ministry of William J. Seymour: And a History of the Azusa Street Revival. (Joplin, MO: Christian Life Books, 1999), 68; and Synan, The Holiness-Pentecostal Tradition, 92.

130 Nell Irvin Painter, Exodusters: Black Migration to Kansas After Reconstruction. (New York: Knopf, 1977), 4. While young single black men had the most opportunity to take advantage of the new freedom and leave, many thousands of black families left Louisiana and other parts of the South to escape racial oppression during Reconstruction. This idea of the free, unattached black male was a great fear of many southern whites, for in the minds of many white southerners, these were the most likely to initiate a black uprising. See, Allen W. Trelease, White Terror; The Ku Klux Klan Conspiracy and Southern Reconstruction. (New York: Harper \& Row, 1971), xlvi.

${ }^{131}$ Baptismal records reveal that he and most of his siblings were baptized in the local Roman Catholic Church in Louisiana, yet until his move to Indianapolis in 1895, almost nothing is known about his personal religious beliefs. See, Martin, The Life and Ministry of William J. Seymour, 55. Vinson Synan claims that Seymour was "raised a Baptist," but includes no citation for this assertion. Vinson Synan, The Holiness-Pentecostal Tradition. 93.

${ }^{132}$ After the war, black churches, previously known as the "invisible institution," became the primary institution for many African American communities. Instead of rejoining the mainline churches, black members frequently formed their own churches and membership skyrocketed in dozens of newly formed denominations. See, Ahlstrom, A Religious History of the American People, 698.
} 
Chapel Methodist Episcopal Church, which was an all-black branch of the mostly white Methodist Episcopal Church in Indianapolis. ${ }^{133}$ While the Methodist Episcopal Church was a mainstream institution, Seymour attended during a period of particular unrest, as some elements within the church broke away to form Holiness sects, which tended to emphasize Christian perfectionism, outward expressions of sanctification, and premillennialism. ${ }^{134}$ When he moved to Cincinnati in 1900, he joined a local branch of the "reformation" Church of God, also known as The Evening Light Saints. ${ }^{135}$ The Saints were a perfectionist sect that taught that human history was approaching its dusk, and that during the last remaining years before Christ's return, God would shower the faithful with supernatural "gifts of the spirit." 136 The group enforced strict standards of "holy living" that included abstaining from coffee, tea, and liquor. Women were forbidden to wear lace or ruffles, and men forbidden to wear bowties. Both sexes were prohibited from wearing gold. ${ }^{137}$ Although the "holy living" standards were quite strict, the group nonetheless was firmly non-sectarian, and was open to all races. This stemmed from their teaching that true Christians should leave

\footnotetext{
133 Douglas J. Nelson, For Such a Time As This: The Story of Bishop William J. Seymour and the Azusa Street Revival, a Search for Pentecostal/Charismatic Roots. Thesis (Ph.D. diss., University of Birmingham, England, 1981). 160. See also Synan, The Holiness-Pentecostal Tradition. 93.

${ }^{134}$ Charles William Shumway, "A Critical Study of 'The Gift of Tongues," (A.B. Dissertation, University of Southern California, 1914), 173.

135 This group was later known as the Church of God Reformation Movement.

136 Cox, Fire from Heaven, 49.

137 John W. V. Smith, A Brief History of the Church of God Reformation Movement, (Anderson, IN: Warner Press, 1976), 32 - 33.
} 
existing denominations in order to become part of the racially inclusive universal church. ${ }^{138}$

Like Parham, illness played a critical role in Seymour's life by initiating a turn towards devout Christian ministry. During his stay with the Evening Light Saints in 1900, Seymour contracted smallpox. Although he survived the disease, his face was left scarred, and he was blinded in one eye. ${ }^{139}$ Seymour's behavior in the wake of his recovery indicates that the smallpox episode had a direct impact on his spiritual dedication. Douglas J. Nelson noted that Seymour "discerned profound meaning in the sickness," and that he interpreted it as "stemming from his disobedience to the divine call. ${ }^{140 " ~ S e y m o u r ~ a c c e p t e d ~ t h e ~}$ spiritual call to preach, and after he had recovered he sought ordination with the Evening Light Saints. ${ }^{141}$

Finally, the last phase of Seymour's religious trajectory is characterized by his relationship with Parham and subsequent adoption of early Pentecostal theology. Seymour was "meek and plain spoken and no orator," claimed one of Seymour's contemporaries Arthur Osterburg, ${ }^{142}$ "He spoke the common language of the uneducated class. He might preach for three-quarters of an hour

\footnotetext{
138 Harvey Gallagher Cox, Fire from Heaven, 49.

139 Shumway, "A Critical Study of 'The Gift of Tongues,"” 173.

140 Douglas J. Nelson, For Such a Time as This: The Story of Bishop William J. Seymour and the Azusa Street Revival, a Search for Pentecostal/Charismatic Roots. Thesis (Ph.D. diss., University of Birmingham, England, 1981), 165.

${ }^{141}$ Nelson, For Such a Time as This, 165.

142 Osterburg was a leader of the Azusa Street Mission, Los Angeles.
} 
with no more emotionalism than that there post. He was no arm-waving thunderer, by any stretch of the imagination." 143 Seymour's understated style of preaching nonetheless impressed many who came to hear.

William Seymour met Lucy Farrow (1851-1911) in 1905 when she attended one of Parham's meetings in Houston. Farrow was the niece of famed abolitionist Frederick Douglass and pastored a small Holiness church in Houston. Like Seymour, Farrow found Parham to be an arresting and persuading figure. "It was at the Bible School in Houston, Texas, that W. J. Seymour and Lucy Farrar (colorer) received the light of the full gospel, and they seldom missed a service. They were hungry for all of God's blessings" wrote one account of the meeting. ${ }^{144}$ When Farrow accepted temporary employment with the Parhams as a governess for their children while they traveled to Kansas, she left her congregation in the hands of Seymour. ${ }^{145}$ In a fateful twist, a Los Angeleno woman named Neely Terry visited Farrow's "small church in the suburbs" while she visited local relatives in Houston. Terry left impressed with Seymour's teachings and when her enthusiasm for this new theology got her and others kicked out of their Baptist church in Los Angeles, she immediately wrote to Seymour. ${ }^{146}$ Seymour later described this "divine calling" to Los Angeles in the Apostolic Faith:

It was the divine call that brought me from Houston, Texas, to Los Angeles. The Lord put it in the heart of one of the saints in Los Angeles to

\footnotetext{
143 John Thomas Nichol, Pentecostalism. (New York: Harper \& Row, 1966), 33.

${ }^{144}$ As quoted in Sarah Parham, The Life of Charles F. Parham, 161.

${ }^{145}$ Borlase, William Seymour, 77.

146 lbid, 96-97.
} 
write to me that she felt the Lord would have me come over here and do a work, and I came, for I felt it was the leading of the Lord. The Lord sent the means, and I came to take charge of a mission on Santa Fe Street. ${ }^{147}$

Like thousands of other Americans of the time, Seymour made the 1,371 mile journey out of Texas to the great American West via railroad. ${ }^{148}$ It was the early spring of 1906 . Seymour was already preaching the imminent return of Christ, divine healing, and glossolalia as a sign of Holy Ghost Baptism. Perhaps he believed these doctrines would find greater acceptance in the more religiously tolerant atmosphere of Los Angeles, but he could not have foreseen the worldwide religious fire that it would spark.

\footnotetext{
${ }^{147}$ Apostolic Faith, September 1906, 1.

${ }^{148}$ Borlase, William Seymour, 88.
} 
CHAPTER 2:

\section{A MODERN PENTECOST: AZUSA STREET AND THE BIRTH OF THE PENTECOSTAL MOVEMENT}

This chapter explores the Azusa Street Revival in Los Angeles 1906 which served as the launching point for the modern Pentecostal movement. The chapter begins with an overview of the city of Los Angeles as a model of the changes discussed in the previous chapter. It then investigates the revival as it was reported on in the local and national press at the time, and as participants described it in their own words. It then scrutinizes the participants and leaders of the revival and their beliefs. The goal of this chapter is to understand the place of Azusa in the history of the Pentecostal movement. There are several schools of thought that have dominated the discussion of the affair. Although scholars disagree on the origins of Pentecostalism, most concur that the Azusa Street Revival played an important role in catalyzing the movement to worldwide success. This chapter seeks to understand why Azusa attracted the attention that it did in 1906, and what this says about its place in history. I argue that Azusa is not only important, but paramount to Pentecostalism, and that it cannot be divorced from its historical context.

This chapter argues that modern Pentecostalism is best understood as an American religious phenomenon that went global for three primary reasons: First, the location of the revival in one of the booming metropolises of the American West created the environment in which this this event could take place and made it easy for the event to get noticed once it was underway; second, the 
demographic composition of the revival crossed many social barriers, making it instantly controversial in the religious and secular press; third, the leaders of the revival advocated a radical message of democratic unity in the Spirit; and finally, the revival occurred in a context of unprecedented millennialism and apocalypticism, particularly among religious groups that were most connected to vast communication networks.

And when the day of Pentecost was fully come, they were all with one accord in one place. And suddenly there came a sound from heaven as of a rushing mighty wind, and it filled all the house where they were sitting. And there appeared unto them cloven tongues like as of fire, and it sat upon each of them. And they were all filled with the Holy Spirit, and began to speak with other languages, as the Spirit gave them utterance. And there were dwelling at Jerusalem Jews, devout men, out of every nation under heaven. Now when this was noised abroad, the multitude came together, and were confounded, because that every man heard them speak in his own language. And they were all amazed and marvelled, saying one to another, Behold, are not all these which speak Galilaeans? And how hear we every man in our own tongue, wherein we were born? Parthians, and Medes, and Elamites, and the dwellers in Mesopotamia, and in Judaea, and Cappadocia, in Pontus, and Asia, Phrygia, and Pamphylia, in Egypt, and in the parts of Libya about Cyrene, and strangers of Rome, Jews and proselytes, Cretes and Arabians, we do hear them speak in our tongues the wonderful works of God. And they were all amazed, and were in doubt, saying one to another, what meaneth this? Others mocking said, these men are full of new wine. ${ }^{1}$

This quote, taken from the Book of Acts in the Biblical New Testament, recounts the events of what is understood in Christian theology as the Day of Pentecost. Christians hold that God's Holy Spirit fell on the apostles, allowing them to speak in foreign languages to the multitude of witnesses present, thereby

${ }^{1}$ Acts 2:1-13, King James Version. 
facilitating conversion. The account of Pentecost plays a critical role in Christian theology and the story is celebrated in varying degrees throughout the many diverse branches of Christianity. The story of Pentecost became especially important in Christian eschatology during the nineteenth century following the rising trajectory of premillennialist eschatology. ${ }^{2}$ Many devout Protestants believed that God would reveal Himself through another Pentecost in preparation for the imminent return of Christ. They wrote about it in religious publications, they spoke about it in sermons, and they prayed that it might happen soon. They looked for signs of a "real" Pentecost that mirrored the first and they waited.

Turn-of-the-century Los Angeles epitomized the promises of modernity, as well as the social, political, and economic turbulence of the Gilded Age. It was a boomtown of the American West; the home of Hollywood and the first city in America to be fully illuminated by electric lights. ${ }^{3}$ The city mirrored the issues associated with the rapid rise of industrialization and urbanization of the period. Many scholars have described the making of modern Los Angeles as a history of conflicts between different interest groups, be they corporations, racial and ethnic groups, business leaders, labor unions, or civil reformers. ${ }^{4}$ The population of Los

\footnotetext{
2 See previous chapter.

${ }^{3}$ D. W. Meinig, The Shaping of America: A Geographical Perspective on 500 Years of History: Volume 3: Transcontinental America 1850-1915. (New Haven: Yale University Press, 1998), 64.

${ }^{4}$ See: James Tejani, "Dredging the Future: The Destruction of Coastal Estuaries and the Creation of Metropolitan Los Angeles, 1858-1913," Southern California Quarterly, Vol. 96, No. 1 (Spring 2014), p. 8. Robert M. Fogelson, The Fragmented Metropolis: Los Angeles, 1850-1930 (Berkeley: University of California Press, 1993); Greg Hise, Magnetic Los Angeles: Planning the Twentieth-Century Metropolis (Baltimore: John Hopkins University Press, 1997); and Steven P. Erie, Globalizing L.A.: Trade, Infrastructure, and Regional Development (Stanford: Stanford University Press, 2004).
} 
Angeles stood at just 4,385 in 1860 , but exploded after the removal of the remaining Native American tribes onto reservations and the ensuing land boom. ${ }^{5}$ This rapid rise in population occurred in no small part to the arrival of the Southern Pacific Railroad in 1876, and the Santé Fe Railroad in $1885 .{ }^{6}$ The allure of temperate climate, abundant land, and general opportunity brought southerners, north-easterners, and mid-westerners of diverse races and cultural backgrounds in massive numbers. The population of Los Angeles doubled from 50,395 in 1890 to 102,479 by 1900 , and by 1906 the city was growing at the rate of 3,000 residents per month. ${ }^{7}$ The county population similarly grew steadily from 101,454 to 170,298 in the last decade of the nineteenth century, rocketing to 504,131 by $1910 .^{8}$

The cosmopolitan city of Angels echoed the composition of the first Pentecost's Jerusalem. Up until the 1870s Los Angeles was what scholar of Mexican-American history Antonio Rios-Bustamante called a "predominantly Mexican town," but with the arrival of the Southern Pacific railroad in 1876 the

\footnotetext{
${ }^{5}$ Cecil M. Roebeck Jr., "The Azusa Street Mission and Historic Black Churches: Two Worlds in Conflict in Los Angeles' African American Community" in Amos Young and Estrelda Alexander, Eds. Afro-Pentecostalism: Black Pentecostal and Charismatic Christianity in History and Culture, (New York, NY: New York University Press, 2011), 22.

${ }^{6}$ Holly Chairman Kane, Arriving in Los Angeles: Railway Depots as Gateways to the Californian Dream. (MA Thesis, University of Southern California, 2007), 2, accessed October 23 ${ }^{\text {rd }}, 2015$. http://digitallibrary.usc.edu/cdm/ref/collection/p15799coll127/id/549791.

${ }^{7}$ Roebeck Jr., "The Azusa Street Mission and Historic Black Churches", 22.

8 "Historical Census Populations of Counties and Incorporated Cities in California, 1850-2010," California Department of Finance, 2013, accessed April 9 9t $^{\text {th }} 2016$. http://www.dof.ca.gov/research/demographic/state_census_data_center/historical_census_18502010/view.php.
} 
population became increasingly Anglo-American as immigrants flooded westward. ${ }^{9}$ As scholar Robert M. Fogelson notes in his history of Los Angeles, the population of Northern and Western European immigrants rose from 12,245 in 1900 to 32,041 in 1910, and the Southern and Eastern European population grew from 1,644 to 13,557 in the same period. ${ }^{10}$ Asian and Mexican populations likewise continued to rise at dramatic rates, and the African-American population more than tripled. ${ }^{11}$ These populations brought with them their own traditions, cultural practices, and religious beliefs, creating a truly cosmopolitan city. As a rapidly developing city of immigrants at the turn of the century, multi-ethnic social networks developed in the city's diverse working-class districts. ${ }^{12}$ These types of social networks were less common in Northern cities, but tended to characterize the metropolises of the American West. In his analysis of these multi-ethnic neighborhoods in turn-of-the-century Los Angeles, Mark Wild contends that in "parts of Los Angeles east and west of the Los Angeles River one could find by the early twentieth century cosmopolitan areas where residents of all races mingled in the streets and public establishments." ${ }^{13}$ Many African American individuals and families moved to Los Angeles in search of opportunity and

\footnotetext{
${ }^{9}$ Antonio Rios-Bustamante, "The Once and Future Majority," California History 60 (Spring 1981), 24.

${ }^{10}$ Fogelson, The Fragmented Metropolis, 76.

11 lbid.

${ }^{12}$ Mark Wild, Street Meeting: Multiethnic Neighborhoods in Early Twentieth-century Los Angeles (Berkley and Los Angeles, CA: University of California Press, 2005), 2.

13 lbid.
} 
employment, and by 1910 the city had the largest concentration of urban African Americans west of Texas. ${ }^{14}$

It was during this period of development that revival broke out in the spring of 1906. Its outbreak in the "City of Angels" was no coincidence, as the city proved to be an ideal setting for the birth of a new mass religious movement. Reflecting on the event in a July 1906 issue of the religious periodical Herald of Light, a contributor named Etta Auringer Huff wrote:

I feel like writing about the wonderful things that are taking place here in Los Angeles. This is a rapidly growing city of about 200,000 inhabitants. I suppose there is not a tongue or people on earth not represented here, more or less. Every religion of note is here. Hindus with their god of stone; Chinese with their red dragons, etc. And all sorts of creeds and isms. What more appropriate place could God choose for a second Pentecost. And it is here; as sure as you live, it is here. ${ }^{15}$

This statement encapsulates the early Pentecostals' belief that this revival was perfectly reflective of the first biblical Pentecost. The city provided the ideal environment for the birth of a new movement that depended on attracting diverse crowds to its cause. As a new city full of uprooted people who had little to no historical or familial connection to the place, it also provided an environment open to new ideas about modern ways of living, thinking, and believing.

In 1906 American papers teemed with stories of local religious sects and their odd, unprepossessing practices. Tales of the exploits of "weird" and "wild"

\footnotetext{
${ }^{14}$ See: Quintard Taylor, In Search of the Racial Frontier: African Americans in the American West, 1528-1990. (New York: Norton, 1998), 206; and Alton Hornsby, Black America: A State-byState Historical Encyclopedia. (Santa Barbara, CA: Greenwood, 2011), 81.

${ }^{15}$ Etta Auringer Huff, "A Scriptural Pentecost," A Herald of Light, July 14, 1906, in Larry Martin, ed., Azusa Street: The True Believers Part 2, (Joplin, MO: Christian Life Books, 1999), 104.
} 
religious sects sold papers and religious fanaticism was a common theme in local newspapers. ${ }^{16}$ But few revivals garnered as much controversy, lampoons, caricatures, news, or rapt attention as the Azusa Street Revival in Los Angeles, California. On April 18th, 1906 the front page of the Los Angeles Daily Times informed readers about a "new sect of fanatics breaking loose" in the downtown working class district of Los Angeles. Entitled "Weird Babel of Tongues," the article told of a "wild scene last night on Azusa street." ${ }^{17}$ A reporter who had attended the mission's services the previous day mockingly sketched the scene:

Breathing strange utterances and mouthing a creed which it would seem no sane mortal could understand, the newest religious sect has started in Los Angeles. Meetings are held in a tumble-down shack on Azusa Street, near San Pedro Street, and devotees of the weird doctrine practice the most fanatical rites, preach the wildest theories and work themselves into a state of mad excitement in their peculiar zeal. Colored people and a sprinkling of whites compose the congregation, and night is made hideous in the neighborhood by the howlings of the worshippers who spend hours swaying forth and back in a nerve-racking [sic] attitude of prayer and supplication. They claim to have "the gift of tongues;" and to be able to comprehend the babel. ${ }^{18}$

Despite the obvious disdain for the event and its participants, the reporter managed to capture the novelty and excitement of the "new sect" as well as provide some clues as to its motivation. "Sacred tenets, reverently mentioned by the orthodox believer, are dealt with in a familiar, if nor irreverent, manner by these latest religionists" wrote the author. ${ }^{19}$ The author quickly focused on the

\footnotetext{
${ }^{16}$ A cursory search of the term "religious fanatics" in the Newspapers.com online database turns up 3,826 matches in newspapers between 1900 and 1910 .

17 “Weird Babel of Tongues" Los Angeles Daily Times, April 18th, 1906. 1.

18 lbid.

19 lbid.
} 
racial composition of the revival and the seemingly bizarre behavior of the participants, which was frequently described as "wild," "weird," and "strange." The article then focused on the most "weird" element of the meeting: speaking in tongues. ${ }^{20}$ While tongues was not an unheard of phenomenon, it was unusual enough to make an impression on the visitor. Clearly unimpressed, the reporter's description of the worship service employed racial stereotypes and unhidden contempt for the events:

After an hour spent in exhortation the brethren present are invited to join in a 'meeting of prayer, song, and testimony.' Then it is that the pandemonium breaks loose and the bounds of reason are passed by those who are 'filled with the spirit,' whatever that may be. 'You-00-00 gon-ioo-ioo come under the bloo-0o-0o boo-ido' shouts an old colored 'mammy,' in a frenzy of religious zeal. Swinging her arms wildly about her she continues with the strangest harangue ever uttered. Few of her words are intelligible, and for the most part her testimony contains the most outrageous jumble of syllables, which are listened to with awe by the company. ${ }^{21}$

"An old colored exhorter, blind in one eye, is the ma-jor-domo of the company" wrote the reporter in his description of the revival's leader, William J. Seymour. ${ }^{22}$ The story continued:

\footnotetext{
20 The term "speaking in tongues" is heavily loaded and can mean different things to different readers. It is especially confusing because contemporary charismatic evangelicals and Pentecostals do not always agree on the definition. For these early years however, the term almost always is meant by the participants as xenoglossia, which means to speak in a language that the person had no former knowledge of. When non-Pentecostals of this period use the term they do so typically to indicate that the person is speaking jibberish. Later, the term can mean speaking in "spiritual" languages that only the participant can understand. It is clear from the sources that these participants however believed that they were speaking actual languages that they had never spoken before.

${ }^{21}$ Los Angeles Daily Times, April 18th, 1906. 1.

22 lbid.
} 
The old exhorter urged the "sisters" to let the "tongues come forth" and the women gave themselves over to a riot of religious fervor. As a result a buxom dame was overcome with excitement and almost fainted. Undismayed by the fearful attitude of the colored worshipper, another black women [sic] jumped to the floor and began a wild gesticulation, which ended in a gurgle of wordless prayers which were nothing less than shocking. "She's speaking in unknown tongues;" announced the leader, in ah [sic] awed whisper, "keep on sister." The sister continued until it was necessary to assist her to a seat because of her bodily fatigue. ${ }^{23}$

This was the first depiction that most Los Angelinos received of the

revival. It would not be the last. Between April 1906 and December 1908 the local Los Angeles newspapers reported on the revival over one hundred times. ${ }^{24}$ The Los Angeles Times and the Los Angeles Herald in particular wrote extensively and famously about the initial revival, frequently employing derogatory terms such as "holy jumpers," and noting their composition as "a motley crowd of negros and whites." 25 Others described whites, Asians, blacks, and Hispanics blending during the events. The Azusa Street Revival featured unorthodox religious practices with scandalous mixing of people from different ethnicities, genders, and classes. While the newspapers were often quite critical of the events, they also provide rich descriptions of these first Pentecostal gatherings. After visiting a June service, a Los Angeles Examiner reporter described the phenomenon of speaking in tongues:

The chorus of tongues' while likewise unintelligible was weirdly beautiful. A colored woman with the voice of a Patti began singing in a tongue which never before was heard. Her voice was joined by a contralto of great

${ }^{23} \mathrm{lbid}$.

24 See: Wild and Weird, Larry E. Martin (113 times) including the Los Angeles Herald, the Los Angeles Daily Times, Los Angeles Record, Los Angeles Express, and the Los Angeles Examiner.

${ }^{25}$ Los Angeles Herald, Volume 33, Number 295, 22 July 1906. 4. 
depth and richness, but singing another tongue. Others took up the chant, each after her own tune and 'tongues' until the building was vocal with the tones of golden mellowness. They say that the Holy Ghost tunes their voices. During the manifestation several who had prayed for the coveted gift fell upon their faces in frenzied appeal and acted otherwise after the manner of persons obsessed. ${ }^{26}$

Unlike Topeka, in Azusa's case even bad publicity was good publicity. The Los Angeles Times had a circulation of forty-five thousand in $1906 .{ }^{27}$ While the articles lampooned the events, they also provided free advertisement for the warehouse-turned-mission at Azusa Street. Initially, hundreds from all over the city crowded into the mission to witness for themselves the bizarre spectacle that they had read about in the papers. Local church parishioners attended to participate in the revival, and local church leaders attended to investigate the new black preacher from Texas and his strange theology. As news of the revival spread quickly throughout the country, the numbers grew into the thousands. ${ }^{28}$

To outsiders, the revival was nothing more than yet another example of radical religious fanaticism, but this would belie the importance of the events at Azusa. In traditional Holiness mode, the Azusa Street Revival began as a cottage prayer meeting. ${ }^{29}$ Seymour's message of Holy Spirit Baptism was not

\footnotetext{
${ }^{26}$ The Los Angeles Examiner, June 11, 1906

${ }^{27}$ Estrelda Alexander, Black Fire: One Hundred Years of African American Pentecostalism, 132.

${ }^{28}$ It is difficult to ascertain the exact number of participants at the revival. The mission kept no records of visitors and there are few documents that remain which would give a specific indication of the numbers or the financial information about the mission. Local newspapers, testimonials from participants, and the mission's periodical remain the best sources for estimating the size and composition of the events.

${ }^{29}$ William Seymour, Apostolic Faith, Sept. 9, 1906, 1. Cottage prayer meetings were common types of meetings held once or twice a week outside the Sabbath where members would typically gather at a member's residence for the purpose of engaging in extemporary prayer, scripture readings, singing, and testimonies.
} 
immediately embraced in the City of Angels. The all-black Holiness congregation to which he arrived was headed by Julia Hutchins, an African American evangelist and pastor. ${ }^{30}$ Hutchins disapproved of the emphasis that Seymour put on the doctrine of Spirit Baptism. Seymour continued preaching that "tongues" were a sign accompanying the baptism of the Holy Spirit, even though he himself had not yet spoken in tongues. When he continued, Hutchins had the church's door padlocked to keep him out. ${ }^{31}$ Without work or shelter, Seymour took refuge in the home of one of the congregation's members, Edward S. Lee. There, Seymour prayed and fasted, and soon other members joined in. "Seymour became known as a man of prayer," as one biographer noted. ${ }^{32}$ This caused commotion in the community when Julia Hutchins learned that he was again leading prayer meetings, and she arranged a formal meeting with Seymour and local Holiness clergy to address the perceived false doctrine. The meeting resulted in something of an impasse, as Seymour contended that unless the Holiness pastors had spoken in tongues, they were not baptized in the Holy Spirit. After the investigation, Richard and Ruth Asbury asked Seymour to move in with them at their modest house at 214 North Bonnie Brae St., centrally

\footnotetext{
${ }^{30}$ Hutchinson was a former member of the Second Baptist Church in LA. She and her followers were turned out due to her teachings on Sanctification as a separate, second act of grace after salvation. This group established an independent Holiness mission on Santa Fe Street, but eventually associated themselves with a Church of the Nazarene. Robert R. Owens suggests that the group desired that a male pastor lead the church, which is why Neely Terry suggested William Seymour. See: Robert R. Owens, The Azusa Street Revival: Its Roots and Its Message.

(Lanham, MD: Xulon Press, 2005), 56.

${ }^{31}$ Nelson, For Such a Time as This, 188.

32 lbid.
} 
located within a small but thriving African American community in Los Angeles, in order that he might hold meetings there. During the prayer meetings, according to one researcher who interviewed many of the participants involved at the time, they fasted and prayed for the baptism of the Holy Spirit:

Some of those who were in that company have told the author that their whole souls, minds, bodies, and all, seemed to center on the desire to obtain the baptism of the Spirit and the sign of the tongues and to determine to remain in prayer until it came. Men left their daily work and spent the time in prayer. Meetings were held on Friday, Saturday and Sunday far into the night. ${ }^{33}$

On April 6th, 1906 William Seymour began leading this group of worshipers in earnest prayer and fasting for revival. Soon after the meetings at Bonnie Brae St. began, Seymour wrote to his friend from Houston, Lucy Farrow for her assistance in the meetings. After Farrow arrived, Seymour began leading the group in a ten day prayer fast that they might receive the baptism of the Holy Spirit. On the third day, Seymour visited Mr. Lee to pray for healing for an ailment. Seymour laid hands on Lee and anointed him with oil, after which Lee claimed to have been healed instantly. After more prayer, Lee began speaking in tongues. This development was certainly encouraging to Seymour, who then went with Lee to the Asbury home and began leading the gathered participants in prayer. In his 1919 dissertation on the phenomena of glossolalia, Charles Shumway recounted the events as told to him by participants at the meeting:

After songs and "brief prayers, Seymour arose to speak, taking his text from Acts 2:4. The first thing he said to the assembly was that Lee had been given the gift of tongues. Jennie Moore, seated on the organ stool,

${ }^{33}$ Shumway, A Critical History of Glossolalia, 174. 
fell to the floor speaking in tongues, and in an instant most of the people in the room were similarly engaged. Her action served as the releasing key, or final suggestion, which they needed. ${ }^{34}$

An African American woman who would later become Seymour's wife, Jennie Evans Moore was the first to speak in tongues at the revival. She claimed to have a vision of cards with words written in French, Spanish, Latin, Greek, Hebrew and Hindustani, which she spoke at the meeting and others interpreted into English. She then jumped up to play the piano, a skill that she claimed she had no former knowledge of. ${ }^{35}$ These actions spurred on the other participants and soon many of the group were also speaking in tongues. The meeting lasted through the night and the next day news of the meeting was beginning to spread, with onlookers showing up to witness it for themselves. One participant named Emma Cotton described the reaction: "People came from everywhere. By the next morning there was no getting near the house. As the people came they would fall under the power, and the whole city was stirred. The sick were healed and sinners were saved just as they came in." ${ }^{36}$ On the sixth day of the fast, Seymour too began speaking in tongues, after praying through the night with "a white man." ${ }^{37}$ Douglas Nelson, a biographer of Seymour, describes the scene:

Two of them remained on their knees together in prayer, determined to "pray through." One was Seymour, the other a white man. Finally, the white friend faltered, exhausted. "It is not the time," he said wearily. "Yes it is" replied Seymour, "I am not going to give up." He kept on, alone, and in

\footnotetext{
${ }^{34}$ lbid, 116.

35 "Music From Heaven" Apostolic Faith, May 1907, 3.

${ }^{36}$ Stanley H. Frodsham, This Pentecostal Revival, (Springfield, MO: Gospel Publishing House, 1941), 23.

${ }^{37}$ Nelson, For Such a Time as This, 192.
} 
response to his last prayer, a sphere of white hot brilliance seemed to appear, draw near, and fall upon him. Divine love melted his heart; he sank to the floor seemingly unconscious. Words of deep healing and encouragement spoke to him. As from a great distance he heard unutterable words being uttered - was it angelic adoration and praise? Slowly he realized the indescribably lovely language belonged to him, pouring from his innermost being. A broad smile wreathed his face. At last, he arose and happily embraced those around him. ${ }^{38}$

Thus from the beginning, the revival emphasized three critical elements:

participant egalitarianism (whereby all could participate, regardless of age, race, or gender), ethnic diversity, and an emphasis on supernatural acts such as healing and speaking in tongues. ${ }^{39}$ The group would offer these three elements as definitive proof that Azusa was the real Pentecost.

Azusa Street became the catalyst for the modern Pentecostal movement because the Azusa Street Pentecostals made it so. While they acknowledged their roots, it was clear from the outset that the leaders of the mission believed that this revival was special, and marked a point of departure from Topeka and Charles Parham's group. ${ }^{40}$ From the beginning, there was a concerted effort to spread news of the revival through religious channels, and particularly through the medium of print, in order to let people know that their mission in Los Angeles, California had been chosen by God as the place where he would work wonders and reveal himself through the Holy Spirit. On the front page of the first issue of

\footnotetext{
$38 \mathrm{lbid}, 192$.

${ }^{39}$ Interracial churches were not unheard of in this time period, but they were uncommon and moreover they certainly did not allow for the type of loose behavior associated with being overcome with the Holy Spirit. That black men and white women might engage in acts of spiritual ecstasy was risky behavior.

${ }^{40}$ See Parham's criticism of Seymour in Parham, The Life of Charles Parham, 164.
} 
the Apostolic Faith, they printed in bold "Pentecost Has Come: Los Angeles being Visited by a Revival of Bible Salvation and Pentecost as Recorded in the Book of Acts" 41 It was the new Jerusalem for the 20th century. By claiming Azusa as the birthplace of the new Pentecost, William Seymour and the leaders at Azusa laid claim to the movement from the beginning. The Azusa Street revival was not simply the catalyst for a movement, it was the movement, at least in the early years.

The revival quickly coalesced around a group of unofficial leaders, who acted as "agents" of the Holy Spirit. From the beginning, the group distrusted traditional church hierarchy. They consistently shunned the term "church" and viewed themselves as the Apostolic Faith Mission or Movement. "Mission" and "movement" were used interchangeably, with the emphasis being on the lack of traditional organization or control by man. "The Apostolic Faith movement is not an organization or controlled by man in any way, but is under the direct control and supervision of the Holy Ghost" claimed the editors of The Pentecost in 1908. ${ }^{42}$ The mission initially had no formal hierarchy of leaders, and did not file articles of incorporation as a church until April 24th, 1907. It did have a credentials committee, which was responsible for examining candidates and then ordaining and licensing ministers and commissioning missionaries for the foreign service. Seven of the twelve members of the original credentials committee were

\footnotetext{
${ }^{41}$ Apostolic Faith, Sept. 9, 1906, 1.

42 The Pentecost, August 1908, 3.
} 
women. One of the few images that still exists of the group at Azusa is of the credentials committee, comprised of Phoebe Sargent, G.W. Evans, Jennie Evans Moore, ${ }^{43}$ Glenn A. Cook, Florence Louise Crawford (1872-1936), Thomas Junk, Sister Prince, May (Mrs. G.W.) Evans, Hiram W. Smith, Clara Lum, and William Seymour. The mission licensed male and female missionaries for the mission field, and marriage was not necessary for consideration or licensing.

William Seymour was the "leader of the movement under God." ${ }^{44} \mathrm{He}$ was revered by those at Azusa and by many who met him described him as a humble man of quiet countenance that stood up to the pressures within and outside the mission. Writing in the spring of 1907, the elderly Adolphus Spalding Worrell credited Seymour with holding up under the pressure:

This work seems to be increasing in power, despite all the efforts of selfappointed critics and antagonists. The writer has not a single doubt but that Brother Seymour has more power with God, and more power from God, than all his critics in and out of the city. His strength is in his courageous weakness, and lowliness before God and so long as he maintains. This attitude the power of God will, no doubt, continue to flow through him. We tremble for some of our friends, who claim that God has revealed to them, that "this whole work is of the devil. ${ }^{45}$

\footnotetext{
${ }^{43}$ An African American city evangelist. Married William Seymour and become an associate pastor in 1908.

${ }^{44}$ Apostolic Faith, February-March 1907, 4.

45 Ibid, 5. A.S. Worrell (1831-1908) was a Landmark Baptist evangelist who converted to Pentecostalism. He was the editor of the Gospel Witness in Kentucky (1893-1908) and became most known for his translation of the New Testament in 1904.
} 
Seymour served as the head pastor and "manager" at the mission. His sermons and letters frequently appeared in the mission's newspaper, The Apostolic Faith. As such, his sermons greatly shaped the theology of the young movement.

On the surface, William Seymour would appear to be the prime cause of the revival and its de-facto leader, but spontaneity and the common believer were more important. This was a spontaneous, activist, do-it-yourself religion. Ascertaining the demographic composition of the revival and early movement has been very difficult for scholars, particularly because the mission did not keep detailed records of members or attendance. As historian Joe Creech notes, "with the rapture close at hand, Pentecostals had more important things to do that write down the names of their earliest converts." ${ }^{46}$ However, Pentecostals did in fact publish many of the names of their converts in their periodicals, and through these testimonials and letters one can get a glimpse of the demographics of the early movement.

First, it is obvious that women played a central role in the revival from the very beginning. Jennie Evans Moore was the first individual to speak in tongues in the early days of the revival. Fully half of the original credentialing committee were women. Clara Lum and Florence Crawford were the behind-the-scenes engines of the periodical, and the majority of published letters in the Apostolic Faith appear to have been written by women. ${ }^{47}$ The specter of female

\footnotetext{
${ }^{46}$ Joe Creech, Righteous Indignation: Religion and the Populist Revolution. (Urbana: University of Illinois Press, 2006), 179.

${ }^{47}$ The author's names are not always listed, and frequently both names are listed if it was a
} 
participation, particularly alongside that of black men, was a frequent topic of criticism in the local papers as well as some religious papers. As evangelists, women proved particularly adept at spreading the message through their social networks. Rachael Sizelove was an early visitor to the Azusa Revival, arriving in April 1906. Sizelove claimed that she had received the Spirit Baptism and went on to organize the first Azusa Street camp meeting in June, 1907. She traveled and spread the Pentecostal message across the Midwest, the South and the West Coast. ${ }^{48}$ Anna Hall was an older evangelist who had worked with Charles Parham before eventually traveling to Azusa St in order to assist in mission work. ${ }^{49}$ In September 1906 Hall reportedly visited a Russian church in Los Angeles and "spoke to the Russians in their own language in their church in Los Angeles as the Spirit gave utterance." ${ }^{50}$ Ivy Campbell (1874-1918) arrived at Azusa in the summer of 1906 and after experiencing her personal Pentecost, then took the message back to her mission in East Liverpool, Ohio, where she shared her testimony at Broadway Mission where she was a leader. She later went on to assist the pastor Claude McKinney in Akron, $\mathrm{OH}$, by leading services at the Union Gospel Mission and launching revivals throughout Ohio and the Midwest. ${ }^{51}$

couple writing. Single female-authored letters were common.

${ }^{48}$ Espinosa, William J. Seymour and the Origins of Global Pentecostalism, 329.

${ }^{49}$ Cecil M. Robeck Jr., The Azusa Street Mission and Revival. (Nashville: Thomas Nelson, 2006), 211.

${ }^{50}$ Apostolic Faith, September 1906, 4.

${ }^{51}$ Frank Bartleman, Azusa Street: An Eyewitness Account. (Plainfield, N.J.: Logos International, 
Second, by all written accounts, the revival attracted a wide range of ethnicities. Azusa Street was located in one of the poorer working class districts of the city, and in the earliest days it was a predominantly African American group. The group acknowledged this fact in their history, stating that "The work began among the colored people." 52 In his analysis of the revival's demographics, Robert Mapes Anderson contends that the revival attracted the "ethnic minority groups of Los Angeles," who discovered a "sense of dignity and community denied them in the larger urban culture. ${ }^{" 53}$ However, it is clear that the revival almost immediately began drawing white attendees as well, most likely local church parishioners who heard of the revival in the papers and desired to investigate for themselves. The group claimed that May Evans was "the first white woman to receive the Pentecost and gift of tongues in Los Angeles." ${ }^{4}$ Reporters tended to emphasize a non-white majority in their reports. At the very beginning in April 1906, a Los Angeles Daily Times reporter described the composition of the congregation as "colored people and a sprinkling of whites." 55 Most of the names that we have of people who attended the Azusa street revival were those printed in the religious periodicals and newspapers. However, while the editors of the Apostolic Faith made efforts to highlight the diversity of their

\footnotetext{
1980). Reprint of the 1925 ed. published under title: How Pentecost came to Los Angeles, 116.

${ }^{52}$ Apostolic Faith, September 1906, 3.

${ }^{53}$ Robert Mapes Anderson, Vision of the Disinherited: The Making of American Pentecostalism (New York and Oxford: Oxford University Press, 1979), 69.

${ }^{54}$ Apostolic Faith, September 1906, 3.

${ }^{55}$ Los Angeles Daily Times, April 18th, 1906. 1.
} 
movement, they rarely gave the specific names or testimonies of non-white immigrants, instead referencing them by their ethnicity only.

In his compilation of approximately 200 names of individuals who lived close enough to have attended the Azusa Street Revival on a regular basis, Cecil M. Robeck approximates that " $45 \%$ were African American, $45 \%$ were Anglo American, and $10 \%$ fell into other categories, the majority of which were Mexican or Mexican American, ${ }^{56}$ and services are estimated to have drawn an average of 500-700 attendees ${ }^{57}$. Yet the initial writings about the revival indicate that its ethnic diversity went far beyond the confines of white and black. Participant Rachel Sizelove remarked "the Lord had chosen this humble spot to gather all nationalities," 58 and internationalism was a common theme of the revival. Mexicans and Mexican Americans were a significant group within the revival. Indeed, they were such a prominent demographic that Seymour sent the Lopezs to found offshoot churches to accommodate the growing numbers of Hispanic converts. ${ }^{59}$

Abundio and Rosa Lopez took the news of Azusa Street to the Hispanophone community in California, thereby facilitating the spread of the movement to Latin America. Abundio Lopez, a Mexican immigrant, was ordained

\footnotetext{
${ }^{56}$ Donald E. Miller, Kimon H. Sargeant, and Richard Flory, eds. Spirit and Power: The Growth and Global Impact of Pentecostalism. (Oxford ; New York: Oxford University Press, 2013), 53. 57 Ibid, 49.

${ }^{58}$ Rachel A. Sizelove, "A Sparkeling Fountain for the Whole Earth," Word and Work, June 1934, 11.

${ }^{59}$ R. G. Robins, Pentecostalism in America. (Santa Barbara, CA: Praeger, 2010), 33.
} 
by the Presbyterians in $1902 .{ }^{60}$ The Lopez family visited Azusa on May 29th, 1906, and, after receiving their "Pentecost," began preaching on the streets of Los Angeles. Their testimonies were printed in the Apostolic Faith in October 1906 in both Spanish and English. The editors of the Apostolic Faith wrote that the Lopez family were useful in "helping Mexicans at the altar at Azusa street," undoubtedly as translators. ${ }^{61} \mathrm{~A}$ Swedish congregation was established for the large number of Swedish immigrants that attended Azusa. There was also a number of Asian immigrants who attended the revival and were frequently cited as corroborating the claims that people were speaking in Asian languages. This Pentecostal rainbow of early believers would soon exemplify the growing body of Pentecostals throughout the Southern hemisphere. The diversity of this group greatly aided missionary efforts, as it gave them instant access to groups that would otherwise be difficult to reach as an outsider.

Third, while the revival was predominantly working class, it became infamous in the press for attracting those from the upper classes as well. A predominant theme of newspaper reports of Azusa and the missions across the country that it inspired was the intermixing of "refined" people with the "grossly ignorant." In December 1906, The Leavenworth Times of Kansas reported on the "Strange Doings of Queer Sect" that had recently established a mission in Leavenworth. "Led by Negro Elder," the reporter wrote, the group "claim that they

${ }^{60}$ Espinosa, William J. Seymour and the Origins of Global Pentecostalism, 345.

${ }^{61}$ Apostolic Faith, November 1906, 4. 
have the gift of tongues." "Refined Women Among Their Converts" read the subheading. ${ }^{62}$

Finally, the Azusa Street Pentecostals came from a wide variety of denominational backgrounds. From the beginning, the leaders claimed that they were not seeking to create a new church or sect, but rather simply desiring a return to the apostolic church. Thus the early Pentecostals simply desired to be a renewal movement within established churches. They enthusiastically reached out to evangelists, pastors, and missionaries to convince them that Pentecost had fallen at Azusa. Their writings indicate that they understood the importance of missionaries in particular: "Reaching the missionaries is laying the axe at the root of the tree, for they know all the customs of India and also the languages. The only way the nations can be reached is by getting the missionaries baptized with the Holy Ghost. Missionaries are receiving and praising God for letting them hear this Gospel and receive this great outpouring of the Spirit." ${ }^{33}$

The experience that visitors traveled to get was predicated on a radical message for its time. Pentecostal theology evolved from Charles Parham, but was developed more thoroughly at Azusa. In the initial years the theology lacked structure and people held wildly varying beliefs, much like the apostolic church they believed they were replicating. Yet there were a few doctrinal commonalities

\footnotetext{
62 "Strange Doings of Queer Sect," The Leavenworth Times, (Leavenworth, Kansas), December 6th, 1906, 8.

${ }^{63}$ Apostolic Faith, September 1907, 1.
} 
present that Seymour developed at Azusa. First and foremost, the group consistently and clearly declared this revival to be the new Pentecost that many had been searching for, effectively branding the revival as the "real" Pentecost. The first issue of the Apostolic Faith declared in bold that "Pentecost has Come!" to Los Angeles, California. The very first paragraph of the very first issue of The Apostolic Faith periodical gushed with the exciting news of Pentecost:

The power of God has this city agitated as never before. To the believers, Pentecost has surely come, and with it the biblical evidences are following, many being converted and sanctified and filled with the Holy Ghost, speaking in tongues as they did on the day of Pentecost. ${ }^{64}$ More than anything Azusa represented to many people a physical, geographical location where one might encounter the divine. In their minds, the Holy Ghost was alive and working at Azusa. Participants described this "deeper experience with God" in varying degrees, most often as "baptism by the Holy Ghost," "sanctification," and "holiness."65 Visitors arrived from all over the United States, and some missionaries in the field traveled to Azusa to receive their own personal "Pentecost" before returning to the mission fields. ${ }^{66}$

The core theological belief that set the Pentecostals apart from other Protestant groups was that the experience of enduement with supernatural power, called "Baptism of the Holy Ghost" was believed to be evidenced by

\footnotetext{
${ }^{64}$ The Apostolic Faith, September 1906, 1.

65 The Weekly Evangel, March 18, 1916, 4.

${ }^{66}$ See: "The Meads, missionaries in central Africa" In The Apostolic Faith, September 1906, 3.
} 
speaking in tongues. ${ }^{67}$ In their written history, the Apostolic Faith Mission of Portland delineated that:

The Baptism of the Holy Ghost, the enduement of power from on High, was first given on the day of Pentecost, and is bestowed only upon those who have been born again and subsequently sanctified. This doctrine, embraced by the Early Church, has been taught by the Apostolic faith since its founding following the outpouring of the Holy Spirit in $1906 .{ }^{68}$

Most Protestants at the time held to cessationism, the belief that the spiritual gifts had ended with the original twelve apostles. The theology of the Baptism of the Holy Ghost held ramifications far beyond the intent of Charles Parham. The most important element of this doctrine was what historian Joseph L. Thomas termed "sanctified unity": that the Holy Spirit fell upon all people equally regardless of age, gender, social standing, or race. ${ }^{69} \mathrm{He}$ explains that "Although no systematic theology exists, sprinkled throughout the corpus of Holiness-Pentecostal writings is a nascent theology arguing for the end of racial and ethnic divisions and the beginning of a new interracial fellowship within the Church of God." 70 Critically, it imbued all with certain spiritual powers, called "gifts

\footnotetext{
${ }^{67}$ This is the interpretation that Assemblies of God historian William Menzies put forward. See Menzies, William W. Anointed to Serve: The Story of the Assemblies of God. (Springfield, Mo: Gospel Pub. House, 1971), 9. Donald W. Dayton agrees and expound in "The Limits of Evangelicalism: The Pentecostal Tradition" in Dayton, Donald W., and Robert K. Johnston. The Variety of American Evangelicalism. (Knoxville: University of Tennessee Press, 1991), 43.

${ }^{68}$ Apostolic Faith Mission (Portland, OR), A Historical Account of the Apostolic Faith, A Trinitarian-Fundamental Evangelistic Organization: Its Origin, Functions, Doctrinal Heritage, and Departmental Activities of Evangelism. (Portland, OR: Apostolic Faith Pub. House, 1965), 21.

69 Joseph L. Thomas, Perfect Harmony: Interracial Churches in Early Holiness-Pentecostalism, 1880-1909. (Lexington: Emeth Press, 2014), 13-14.

70 lbid, 56.
} 
of the Spirit." These gifts included divine healing, tongues and interpretation, and prophesy.

Divine healing featured prominently at the mission on Azusa Street and the early Pentecostals were able to draw many converts from the Holiness movement and Healing groups. Witnesses at the revival described hundreds of healings in Pentecostal periodicals including lameness, cancer, rheumatism, arthritis, blindness, tuberculosis, asthma, and consumption. Seymour equated sickness with original sin, and believed that just as sanctification of the spirit was possible, so was sanctification of the body, for "sickness and disease are destroyed through the precious atonement of Jesus ${ }^{71}$ " and therefore "He will heal every case." 72

Many of the influential leaders in the first generation of Pentecostals grew up in circles that endorsed the practice of divine healing. In particular, many converts arrived from John Alexander Dowie's group in Zion City, IL. Walter Hollenweger identified "thirty-nine prominent Assembly of God leaders...as former followers of Dowie." ${ }^{73}$ John Graham Lake was one such healer. ${ }^{74}$ Lake

\footnotetext{
${ }^{71}$ Seymour, Apostolic Faith, Sept. 9, 1906, 1.

72 Ibid.

${ }^{73}$ Robert Mapes Anderson cites Walter J. Hollenweger in Anderson, Robert Mapes. Vision of the Disinherited: The Making of American Pentecostalism. (New York: Oxford University Press, 1979), 270 fn. 50.

${ }^{74}$ Like many others in the Holiness-Pentecostal Healing circuit, Lake's beliefs in divine healing were shaped by the teachings and ministry of John Alexander Dowie. Lake visited the Dowie Healing Home in Zion City, IL in 1894 where he claimed that he was healed of chronic constipation and rheumatism. Amazed by what he perceived to be divine intervention in the physical realm, Lake brought his brother, Fred Lake and his sister, Mrs. William Otto to Zion in 1896 where he claimed they were both healed; his brother from gum hemorrhage and joint pain,
} 
was a Canadian-born Methodist evangelist prior to his involvement in the Holiness movement and later Pentecostal movement. He was a successful businessman, and one of the more wealthy ministers before he left his job for South Africa after converting to Pentecostalism. ${ }^{75}$ Like William Seymour and Charles Parham, John G. Lake's life and ministry was deeply impacted by personal experience with disease and death. One of sixteen children, Lake lost eight of his siblings from illness while he was growing up. "For 32 years some member of our family was an invalid...During this period our home was never without the shadow of sickness," wrote Lake. ${ }^{76}$ Lake visited the Azusa Street Revival services and was impressed by the leadership of Seymour, saying "He had the funniest vocabulary. But I want to tell you, there were doctors, lawyers,

and his sister from breast cancer. Lake declared that his wife Jennie was miraculously healed in 1898 from heart disease that had manifested over the course of five years. In all three cases, Lake claimed that divine intervention had succeeded where previous medical treatments had failed. In Jennie's case, prayer would be required many more times in order to "heal" her from multiple health issues including diptheria, tuberculosis, curvature of the spine, difficult childbirth, erysipelas, and rheumatism. The Lakes intensified their spiritual devotion with every progressive health obstacle. Most dramatic of all, in August 1900 Jennie was accidentally shot in the spine by their four year old son Horace, who had found a revolver while playing at a friend's house. The Lakes refused medical treatment, and Jennie lay in bed for weeks attended to by an African American woman and other Zion members. The local newspapers criticized the Lake's response and one local doctor even managed to organize a group to burn down the Christian Catholic Church Zion Hall in the town, but Jennie managed to recover sufficiently before the attack. See: Divine Healing, John G. Lake, Philadelphia, Pennsylvania January 30, 1914. In John G Lake the complete collection, 115. This instance implies that he was healed prior to Dowie's Healing home, when Lake was a Methodist minister. Kemp Pendleton Burpeau contends that it was at Dowie's healing home that Lake was healed (God's Showman, 31); "Cheering Words From Zion's Guests: Notes From Zion Home" Leaves of Healing, Vol 7, No. 14. February 5th, 1916. Chicago, IL. 440; and "God's Witness to Divine Healing" Leaves of Healing, Vol 9, No. 8. June 15th, 1901. Chicago, IL. 225-228.

${ }^{75}$ See: Cathy Crompton and Audrey Ryan. God in Action: Revival in South Africa. (Port Elizabeth, South Africa: Crompton Ministries, 1994), 4.

${ }^{76}$ John G. Lake, and Wilford H. Reidt. Adventures in God, (Tulsa, OK: Harrison House, 1981), 74. This manuscript was compiled by John G. Lake's son-in-law, Wilford H. Reidt. 
and professors listening to marvelous things coming from his lips. It was not what he said in words; it was what he said from his spirit to my heart that showed me he had more of God in his life than any man I had ever met up to that time. It was God in him who was attracting people."77 Lake would reunite with Thomas Hezmalhalch in Indianapolis, IL and from there the duo would form a group to take the news of the Azusa Street Revival to South Africa.

Arguably the ultimate proof of this new Pentecost was the breakdown of social barriers at Azusa. ${ }^{78}$ Seymour believed that the baptism of the Holy Spirit erased divisions of class, race, gender, and nationality. Therefore, in order to prove that the Holy Ghost Baptism was real, this revival would have to present evidence that these traditional barriers were indeed being overcome. The Apostolic group therefore consistently promoted evidence of people coming together in total disregard of these social barriers. The editors and leaders of the mission consistently emphasized the cosmopolitan nature of the revival. "God is no respector of persons" was the anthem to their cause. ${ }^{79}$ The Holy Spirit "fell"

\footnotetext{
77 John G. Lake, Adventures in God, (Tulsa, OK: Harrison House, Inc., 1981), 18-19.

${ }^{78}$ While scholars of Pentecostalism are divided on to what degree these social barriers were actually torn down, I take the postion with Jacobsen and Thomas that this was a critical element of the early movement and as Jacoben notes, the "ultimate sign" of Holy Ghost Baptism. See: Douglas Gordon Jacobsen, Thinking in the Spirit: Theologies of the Early Pentecostal Movement. Bloomington: Indiana University Press, 2003, 79; and Joseph L Thomas, Perfect Harmony: Interracial Churches in Early Holiness-Pentecostalism, 1880-1909. 2014.

${ }^{79}$ Apostolic Faith October 1906, 1,3. The phrase "God is no respector of persons" was also seen as a fundamental precept of black Christianity as a challenge to white prejudice. For more see: Eddie S. Glaude, "Of the Black Church and the Making of a Black Public," in West, Cornel, and Eddie S. Glaude. African American Religious Thought: An Anthology. (Louisville, KY: Westminster John Knox Press, 2003), 339; Donald G. Mathews, Religion in the Old South. (Chicago: University of Chicago Press, 1977), 219; Milton C. Sernett, Black Religion and American Evangelicalism: White Protestants, Plantation Missions, and the Flowering of Negro
} 
upon children, the old, all races, and both sexes no matter their status in life. In a 1916 article on the movement, Azusa participant A.W. Orwig described the composition of participants at the revival:

One thing that somewhat surprised me at that first meeting I attended, and also subsequently, was the presence of so many persons from the different churches, not a few of them educated and refined. Some were pastors, evangelists, foreign missionaries, and others of high position in various circles, looking on with seeming amazement and evident interest and profit. And they took part in the services in one way or another. Persons of many nationalities were also present, of which Los Angeles seems to be filled, representing all manner of religious beliefs. Sometimes these, many of them unsaved, would be seized with deep conviction for sin under the burning testimony of one of their own nationality, and at once heartily turn to the Lord. Occasionally some foreigner, although somewhat understanding English, would hear a testimony or earnest exhortation in his native tongue from a person not at all acquainted with that language; thereby be pungently convicted that it was a call from God to repent of sin: often such repentance followed just as on the day of Pentecost. ${ }^{80}$

At the beginning of the twentieth century, the famous sociologist and African American intellectual W.E.B. Du Bois proclaimed in The Souls of Black Folks that "the problem of the Twentieth Century is the problem of the colorline." ${ }^{81}$ Frank Bartleman, a participant and one of the foremost documenters of the revival at the time, famously claimed that "the color line was washed away in the blood" at the Azusa street revival. ${ }^{82}$ William Seymour pointed to the interracial

Christianity, 1787-1865. (Metuchen, N.J.: Scarecrow Press, 1975), 108.

${ }^{80}$ A.W. Orwig, "Apostolic Faith Restored: A History of the Present Latter Rain Outpouring of the Holy Spirit Known as the Apostolic or Pentecostal Movement by B.F. Lawrence, Article X.: My First Visit to the Azuzu [sic] Street Pentecostal Mission, Los Angeles, California." The Weekly Evangel, March 18th, 1916, 4.

81 William Edward Burghardt Du Bois, The Souls of Black Folk. (Mineola, NY: Dover Publications, 1994), V.

82 Frank Bartleman, How "Pentecost" Came to Los Angeles. (Los Angeles, 1925), 54. 
composition of the revival as proof that it was of God and not man. The multiethnic cosmopolitanism of the revival was also a prominent feature in the mission's magazine. The editors remarked:

It is noticeable how free all nationalities feel. If a Mexican or German cannot speak in English, he gets up and speaks in his own tongue and feels quite at home for the Spirit interprets through the face and people say amen. No instrument that God can use is rejected on account of color or dress or lack of education. ${ }^{83}$

While Seymour wholeheartedly adopted Parham's teachings on the second blessing and speaking in tongues as evidence of spiritual baptism, his travels throughout the Midwest and prior experience with other interracial Holiness groups led him to believe that racial harmony was necessary in the church, and this was the most substantial difference between him and his predecessor. After the Civil War Protestant congregations had tended to segregate and while interracial revivals and prayer groups were not unheard of, they were still relatively rare. A report on the initial meetings printed in The Gospel of the Kingdom, a Texas publication by J. G. Campell, illustrates the degree to which racial segregation played a role:

The teaching here came by a colored man, (Seymour), and a mulatto woman, (Lucy Farrar.) Both called to bring the blessed teachings they had received in Houston, Texas, of Brother Chas. F. Parham, to the 'black race' here, but found no open doors among the colored people; but a door was opened among the Holiness people, where both black and white held cottage prayer meetings in a house of one of the members on number 214 Bony Bray; and Mr. Seymour received the baptism of the Holy Spirit here.

83 The Apostolic Faith, November 1906, 1. 
Men and women sought more of God and their labor was blest. They sought wider fields, and rented an old building down town on Azusa St. ${ }^{84}$ Interracial worship was critical to the message of Azusa Street, as it was seen as something of a miracle in its own right. The interracial nature of the revival attracted many pastors of color who might not have otherwise attended. M.L. Ryan was an African American pastor of a church in Salem, Oregon, and publisher of a "small paper." He traveled to Azusa and claimed to speak "in a very large number of tongues." 85 In what was one of the worst periods of racial segregation in American history the Azusa Street Pentecostals actively sought out and embraced ethnic diversity.

Race was a common factor in the characterization of the Azusa Street Revival. The years straddling the dawn of the twentieth century have been famously characterized by historian Rayford Logan as the "nadir" of race relations in American history due to the unsettling amount of discrimination, segregation, and violence against African-Americans, particularly in the South. ${ }^{86}$ After the War, the churches became more segregated than ever. One of the few places that racial harmony was promoted was in some branches of the Holiness movement, but even Charles Parham, the so-called father of Pentecostalism,

\footnotetext{
${ }^{84}$ Parham, The Life of Charles F. Parham, 162.

85 J. C. Vanzandt, Speaking in Tongues: A Discussion of Speaking in Tongues, Pentecost, Latter Rain, Evidence of Holy Spirit Baptism and a Short History of the Tongues Movement in America and Some Foreign Countries. (Portland, OR: The Author, 1926), 32.

${ }^{86}$ See Rayford Whittingham Logan, The Negro in American Life and Thought: The Nadir, 18771901. (New York: Dial Press, 1954).
} 
was horrified to see the level of interracial mixing at Azusa. ${ }^{87}$ It is clear from the writings that Seymour and the editors desired and specifically promoted racial harmony in the church. Charles Parham visited the revival in the fall of 1906 and his reaction to the sight of black men and white women intermingling in the church services was a reflection of the times. Approaching the mission, Parham described hearing "chatterings, jabberings, and screams," and once inside he announced to Seymour that "God is sick at His stomach!"88

Why exactly Charles Parham was disgusted with the behavior at the Azusa Street mission is unknown. It is unlikely that it was simply because of the extreme physical manifestations of emotion, for his Bible college endorsed similar acts and the first revival of this sort occurred in Topeka Kansas under Parham's watch. Parham himself had also advocated similar types of worship style in Topeka and Houston, and within his own writings, so this particular offense makes little sense. What is far more likely is that Parham was outraged by the interracial mingling at the services, especially when considering his previous position in Houston on segregated classes and worship services, and his prior books that indicated his beliefs in the superiority of the white AngloSaxon race. ${ }^{89}$ As he still considered himself the father of the movement, Parham likely was horrified at the thought of having his name associated with revival.

${ }^{87}$ Charles F. Parham, "Free Love," Apostolic Faith, December 1912, 4.

88 Shumway, A Study of the "gift of tongues," 178.

${ }^{89}$ See Charles. F. Parham, A Voice Crying in the Wilderness, and The Everlasting Gospel, 1st ed. (Baxter Springs, KS: Apostolic Faith Bible College, 1911). 
Parham's language when he described the events at Azusa is telling: “...men and women, whites and blacks, knelt together or fell across one another; frequently a white women, perhaps of wealth and culture, could be seen thrown back in the arms of a big 'buck nigger,' and held tightly thus as she shivered in freak imitation of Pentecost. Horrible, awful shame!"90 Thus while Parham used interracial worship as a sign that the Azusa Revival was a false Pentecost, Seymour and the others at Azusa did the exact opposite by emphasizing that Baptism of the Holy Spirit on all at the Revival was proof that it was the authentic Pentecost.

The Azusa Street Revival leaders also emphasized the heavy involvement of women within the movement as proof of God's blessing and divine sanction. Pentecostals consistently offered the apostolate of women as "proof" that this was the "real" Pentecost. In an article published in The Weekly Evangel, evangelist A.G. Jeffries lauded the role of women in the churches:

A marked feature of this "latter day" outpouring" is the Apostolate of women. If a woman gave birth to our Lord, why not her daughters take part in His great work. Men have hypocritically objected to women making themselves conspicuous in pulpit work, but, thank God, this conspicuousness is of God Himself. They did not push themselves to the front. God pulled them there. They did not take this ministry on themselves, God put it on them. Today more than one-half of the missionary force is composed of women. At home they are in almost every village preaching and working in every way conceivable. ${ }^{91}$

90 Charles F. Parham, "Free Love," Apostolic Faith, December 1912, 4.

${ }^{91}$ A.G. Jeffries, "The Limit of Divine Revelation" The Weekly Evangel, March 18th, 1916. 6. 
Of course, 1906 was a problematic era for women leadership in the church. In the US, women would not gain the right to vote for another fourteen years, but women were becoming ever more involved in the public sphere. ${ }^{92}$ Nonetheless, it was still relatively controversial for a religious group to advocate the ecclesiastical equality of women. Like the burgeoning national women's rights movement, Protestant women were asserting ever more power within their respective social spheres, but there were still roadblocks to female leadership in most churches. Yet at Azusa, women were involved at all levels of the mission from the very beginning. The earliest meetings were of gathered African American domestic workers. ${ }^{93}$ At the mission, women played an important, if not prominent role as female pastors and co-pastors. They helped ignite the revival at Azusa, and were foundational to spreading the news of the revival to congregations and individuals across the nation. Historian Grant Wacker suggests that the admittedly sparse evidence strongly suggests that the majority of initial converts were female. ${ }^{94}$ As theologian Valarie Cooper notes, "When the

\footnotetext{
92 For more see: Carl Degler, At Odds: Women and the Family in America from the Revolution to the Present. (New York: Oxford University Press, 1980); Eleanor Flexner, Century of Struggle:

The Women's Rights Movement in the United States. (Cambridge: Belknap Press, 1975); Joseph Mahoney, "Woman Suffrage and the Urban Masses." New Jersey History 87, no. 3 (1969): 151172; Genevieve McBride, On Wisconsin Women: Working for Their Rights from Settlement to Suffrage. (Madison: The University of Wisconsin Press, 1993); Kathleen D. McCarthy, Lady Bountiful Revisited: Women, Philanthropy and Power. (New Brunswick: Rutgers University Press, 1990); Anne Firor Scott and Andrew McKay Scott, One Half the People: The Fight for Woman Suffrage. (Urbana: University of Illinois Press, 1982); Marjorie Spruill Wheeler, New Women of the South: The Leaders of the Woman Suffrage Movement in the Southern States. (New York: Oxford University Press, 1993).

${ }^{93}$ Cheryl J. Sanders, Saints in Exile: The Holiness-Pentecostal Experience in African American Religion and Culture. (New York: Oxford University Press, 1999), 29.

${ }^{94}$ Wacker, Heaven Below, 160.
} 
Pentecostal movement finally dawned, women (particularly black women) regarded the urgency of the hour as all the justification they needed to engage in very public preaching, teaching, evangelistic and healing ministries." 95 Women worked as evangelists and went to the mission field as they felt called, regardless of their marriage status. The editors of the Apostolic Faith justified the involvement of women, saying "It is contrary to the Scriptures that woman should not have her part in the salvation work to which God has called her. We have no right to lay a straw in her way." 96

Age barriers were likewise shattered at Azusa. Children were intimately involved in the revival, and were frequently featured in testimonies and reports. "I am saved, sanctified and baptized with the Holy Ghost and have the Bible evidence" wrote Leila McKinney, the niece of Julia Hutchins in October 1906. Leila claimed she had received "the language of Africa" through the Baptism and that God provided her with the fare to accompany her aunt to Liberia. ${ }^{97}$ Children were often displayed in contrast to salaried pastors and theologians as proof that God was working through the revival. "He is using even the children to preach His gospel," proclaimed the editors of the Apostolic Faith. They claimed that "A young sister, fourteen years old, was saved, sanctified and baptized with the

\footnotetext{
${ }^{95}$ Valarie Cooper, "Laying the Foundations of Azusa: Black Women and Public Ministry in the Nineteenth Century," in Yong, Amos, and Estrelda Y. Alexander, eds. Afro-Pentecostalism: Black Pentecostal and Charismatic Christianity in History and Culture. (New York: NYU Press, 2012), 77.

96 "Who May Prophesy?" The Apostolic Faith, January 1908, 2.

97 The Apostolic Faith, October 1906, 1.
} 
Holy Ghost and went out, taking a band of workers with her, and led a revival in which one hundred and ninety souls were saved." ${ }^{88}$ Stories like this sought to show that anyone regardless of age could receive the Holy Spirit:

A number of children have been baptised [sic] with the Holy Ghost. A sister at Hermon has been holding a daily children's meeting and three children have been baptised [sic] with the Holy Ghost. One Sunday night also at Azusa Street Mission three little girls, sisters, were baptized with the Holy Ghost and each of them spoke in tongues, and different languages. It was touching to see how they went to praying for others at the altar. They had to leave with their mother for Canada and expect to cross the ocean from there, but before they left the Lord gave them their Pentecost. A number of children have been clearly saved and sanctified in the Sunday afternoon children's meeting, led by the boy preacher, Clayborn, on Sunday afternoons and some have received the gift of the Holy Ghost, and God is using their testimonies. ${ }^{99}$

Child preaching has long roots in American Protestantism, but the doctrine of Holy Spirit Baptism gave this peculiar practice more credence within the Pentecostal movement. Children were encouraged to participate in services.

Some noted that "Little children from eight years to twelve stand up on the altar bench and testify to the baptism with the Holy Ghost and speak in tongues. In the children's meeting little tots get down and seek the Lord." 100 The group claimed that Holy Ghost Baptized children were especially effective as witnesses to the unsaved. During a trip to Zion City, IL in September 1907, Seymour wrote to the Azusa Street Mission, saying,

People here receive the baptism in their pews while the service is going on and sometimes scores of them receive it. It is the sweetest thing you

\footnotetext{
98 The Apostolic Faith, October 1906. 3.

99 lbid.

100 The Apostolic Faith, November 1906. 1.
} 
want to see. It reminds me of old Azusa ten months ago. The people that receive the baptism seem so happy. They remind me of our people at home. There are little children from six years and on up who have the baptism with the Holy Ghost, just as we have it in Los Angeles. ${ }^{101}$

Reports of children being saved, sanctified and speaking in tongues featured extensively in missionary reports as well.

Pentecostalism has long been associated as a working class religious movement. Scholars like Robert Mapes Anderson have contributed to this understanding, and the heavy growth of Pentecostalism in the third world has no doubt played a role in promoting this vision. However, the reality of class composition has always been more complicated. The Apostolic Faith Mission promoted its working class roots but also its demographic diversity. In his discussion of the movement, evangelist A.G. Jeffries wrote:

At no time in the world's history has God called as many artisans and day laborers into the vineyard, as He has done in the last few years. Blacksmiths have left their anvils. Farmers their plows, doctors their patients, lawyers their clients, peddlers their packs, merchants their counters, carpenters their tools, engineers their engines, miners their picks, cattlemen their cattle, and have gone out to tell the gospel story. Education and culture are at a discount in this great battle for souls. The call now is not based on what we know, but what we have. The reception of the Holy Ghost postulates qualification, not so much to teach souls as to win souls. ${ }^{102}$

101 William J. Seymour as quoted in "In the Last Days: The 'Latter Rain' in Zion City, III." In the Apostolic Faith, V1N9, September 1907, 1.

102 A.G. Jeffries, "The Limit of Divine Revelation" The Weekly Evangel, March 18th, 1916. 7. 
The editors of the mission's periodical claimed that "All classes and nationalities meet on a common level." ${ }^{103}$ Yet they also highlighted the humble beginnings of the mission. As one Los Angeles Methodist recounted:

I was a leaders of the praying band of First Methodist Church. We prayed that Pentecost might come to the city of Los Angeles. We wanted it to start at First Methodist church, but God did not start it there. I bless God that it did not start at any church in the city, but in a barn, so that we might all come and take part in it. If it had started in a fine church, poor colored or Spanish people would not have got it. ${ }^{104}$

There were numerous similarities to the first Pentecost that the Azusa Street group highlighted and advocated. First, by claiming xenolalia as physical "proof" of a believers baptism in the Holy Spirit, William Seymour and the Azusa Street leaders effectively trademarked the practice. This was an important theological difference that set them apart from prior holiness groups and revivals. Glossolalia, or speaking in tongues, ${ }^{105}$ was not a new phenomenon, as it had been loosely practiced by some sects for millennia. The Azusa Street Pentecostals claimed that this was not gibberish however, but real foreign languages and therefore xenolalia. ${ }^{106}$ The practice originates from the first account of Pentecost in the Gospel book of Acts. In that first instance, the disciples claimed that the Holy Spirit descended upon them and they spoke in

103 "BEGINNING OF WORLD WIDE REVIVAL," The Apostolic Faith, January 1907, 1.

${ }^{104}$ Word and Work, April 1907. Reprinted in Chosen Vessels, 58.

${ }^{105}$ Typically means speaking in a variety of languages or non-sensical/mystical languages that only the speaker can understand.

${ }^{106}$ The act of speaking in a language that the user had no previous knowledge of. 
foreign tongues. This fulfilled the purpose of translating God's message to the diverse group that were gathered around, thereby allowing each person to hear the word of God in their native language. This supernatural act placed the participant as an active agent of God.

Speaking in tongues had a specific purpose: to pave the way for ordinary Americans to fulfill the Great Commission. Indeed, the gift of tongues removed the language barrier that kept many would-be missionaries from joining the mission field and thereby democratized the missionization process. The editors reported:

A minister says that God showed him twenty years ago that the divine plan for missionaries was that they might receive the gift of tongues either before going to the foreign field or on the way. It should be a sign to the heathen that the message is of God. The gift of tongues can only be used as the Spirit gives utterance. It cannot be learned like the native tongue, but the Lord takes control of the organs of speech at will. It is emphatically God's message. ${ }^{107}$

Premillennialists of the late nineteenth century believed that in the last days God would pour out His Spirit on Christians, allowing them to speak in tongues for the purpose of saving souls before the return of Christ. Time was of the essence:

Many are the prophesies spoken in unknown tongues and many the visions that God is giving concerning His soon coming. The heathen must first receive the gospel. One prophecy given in an unknown tongue was interpreted, "The time is short, and I am going to send out a large number in the Spirit of God to preach the full gospel in the power of the Spirit. ${ }^{108}$

107 Seymour, The Apostolic Faith, Sept. 9, 1906, 1.

108 The Apostolic Faith, Sept. 9, 1906, 1. 
What differentiated the Pentecostals from other evangelical groups was their claim that glossolalia was not simply one miraculous act among others, but that it was definitive "proof" or "evidence" of total sanctification. ${ }^{109}$ Parham had been the first to associate it with Holy Spirit Baptism, but Seymour had taken it one step further by claiming it was the necessary "proof" of spiritual baptism. By making it the central highlight of the revival, the group indelibly tied it to the movement. It was consistently described in detail, and always with the purpose of missions. In practice, one person would begin speaking in "an unknown" tongue, and another would translate. Glossolalia essentially removed the need for extensive training in languages for those who felt called for the mission field.

The theology of speaking in tongues as evidence of Holy Ghost Baptism was not accepted by holiness groups. Many denounced Seymour and the Azusa Street Revival participants as apostates, or at the very least misguided believers. The opposition was swift and pronounced. In the $1907 \mathrm{Feb} /$ March edition, the editors mentioned that despite the "great opposition from church people and holiness professors," the movement was still going strong. ${ }^{110}$

The leaders at Azusa were concerned about authenticity and wanted to prove that the "tongues" that were being spoken were actual, translatable languages. They viewed themselves as attacked on all sides by the secular

\footnotetext{
${ }^{109}$ See William W. Menzies, Anointed to Serve: The Story of the Assemblies of God. (Springfield, Mo: Gospel Pub. House, 1971), 9. Donald W. Dayton agrees and expound in "The Limits of Evangelicalism: The Pentecostal Tradition" in Donald W. Dayton and Robert K. Johnston. The Variety of American Evangelicalism. (Knoxville: University of Tennessee Press, 1991), 43.

110 The Apostolic Faith, March 1907, 3.
} 
press and by other Christian groups who deemed them as fake and false. The local press deemed the practitioners' words to be nothing more than unintelligible babbling. ${ }^{111}$ The Azusa Street leaders therefore invited people of all ethnicities and backgrounds to the revival to ascertain that the languages were indeed real.

One account of speaking in tongues illustrates the intricacies of the practice:

On Aug. 11th, a man from the central part of Mexico, an Indian, was present in the meeting and heard a German sister speaking in his tongue which the Lord \&ad given her. He understood, and through the message that God gave him through her, he was most happily converted so that he could hardly contain his joy. All the English he knew was Jesus Christ and Hallelujah. He testified in his native language, which was interpreted by a man who had been among that tribe of Indians. This rough Indian, under the power of the Spirit was led to go and lay his hands on a woman in the congregation who was suffering from consumption, and she was instantly healed and arose and testified. ${ }^{112}$

They frequently published letters from people who had prior linguistic expertise and who wrote in to verify that the languages heard as Azusa Street were genuinely authentic. George E. Berg, a former missionary to India, and a secretary at the Azusa Street mission wrote:

When I knelt seeking the baptism with the Holy Ghost, the Spirit spoke through one man most beautifully in a language of India a precious message... There are very few that get the native accent by study, but this man spoke the beautiful accent of that country. ${ }^{113}$

\footnotetext{
111 See: "Religious Fakers," Los Angeles Record, July 21, 1906; "Baba Bharati Says not a Language," Los Angeles Daily Times, September 19, 1906.

112 The Apostolic Faith, September 1906, 3.

${ }^{113}$ AF, 01/07, Pg. 4. See also, Bergunder, Michael. The South Indian Pentecostal Movement in the Twentieth Century. (Grand Rapids, MI: William B. Eerdmans Pub. Co, 2008), 24.
} 
The descriptions of speaking in tongues were highly varied, and included men, women, the old and the young. They did contain some similarities. The incidents that were printed frequently involved an individual speaking in an exotic language in the presence of either a native speaker or an expert in that language. They were specific when detailing the examples: a "Scottish or Irish" man spoke in High German, ${ }^{114}$ a participant spoke in perfectly accented Indian language, a missionary couple from South Africa spoke in perfect Zulu, after five years of difficulties learning the language in the country, ${ }^{115}$ They also called upon linguistic experts to check their claims. They frequently described the languages being spoken as "new," "strange," and "clear," but the most common adjective by far was "perfect."

Many evangelicals did not believe that the sounds coming from the lips of participants were actual foreign tongues. J.F. Washburn, a prominent Holiness pastor, visited Azusa and remained unconvinced of the authenticity of the act of speaking in tongues:

The meetings were accompanied with great excitement... Strange manipulations were carried on over those seeking, often surrounding them, laying on of hands, patting their jaws and chattering over them in their eagerness to help them to get the much coveted gift of Speaking in Tongues. Ever and anon some one would be seized with a strange spell and commence a jabberish of sounds which neither the party so affected nor any of the congregation understood or knew what it all meant, yet they claimed it was the gift of Tongues and that they now had received the baptism of the Holy Ghost...So sure were some that they had received certain unknown tongues that they sacrificed their homes, selling them

114 The Apostolic Faith, March 1907, 3.

115 lbid. 
and taking the money to take them to heathen lands as supposedly ordered of God, fully believing they had the language of the people to whom they were divinely sent. But, alas! to their great surprise and chagrin, the native people to whom they went (Liberia, Africa), could not understand a word of their supposed African tongue or language. Some died in these far away lands (one whole family) soon after reaching there. Others more fortunate had means to bring them to the home lands, the sadder and wiser for the experience, freely acknowledging their error to us in person. Others in other parts of foreign fields, who sold all and went, are piteously writing to friends in California, longing for help to return from their wild, misled mission, finding they in like manner had no Gift of Language, as they had firmly believed to have. ${ }^{116}$

Some participants believed that tongues were a gift of the Spirit, but acknowledged that not all of those "speaking in tongues" were actually speaking intelligible languages, but were rather merely engaging in mimicry. A.C. Worell, a well-known evangelist, described the problem at the revival when he visited, declaring Satan "a counterfeiter from of old; but he would not play in any role as counterfeiter, unless there was something to counterfeit." Worell wrote "There are real gifts of tongues here in Los Angeles, and other gifts of the Spirit. Satan is trying to counterfeit these; and, beyond any reasonable doubt, he has succeeded in counterfeiting the gift of tongues, and some of the other gifts as well."117

Finally, the "signs and wonders" highlighted at the Azusa Street Revival reaffirmed many Protestants' apocalyptic and premillennialist beliefs. The very same day that the Los Angeles Daily Times broke the first news of the revival, the state of California was hit by a 7.8 earthquake that nearly destroyed all of

\footnotetext{
116 J.F. Washburn, History and Reminisces of The Holiness Church Work in Southern California and Arizona. (Pasadena, CA: Record Press. 1920), 388-89.

117 Originally in Gospel Witness, reprinted in Triumphs of Faith, Dec 1906. Reprinted in Larry E. Martin, Saved and Sanctified, 80.
} 
San Francisco. Over 3000 people were killed in the quake, and it was reported to have caused over $\$ 524$ million in property damages. ${ }^{118}$ This was no coincidence for those who already believed they were living in the end times. In his description of the history of the revival, the itinerant evangelist and Azusa Street participant Frank Bartleman wrote that the earthquake "had a very close connection with the Pentecostal outpouring... Men began to fear God... This paved the way for the revival." ${ }^{\text {119 }}$ Bartleman quickly published a tract about the earthquake and within a few weeks over 40,000 were distributed in Los Angeles alone. ${ }^{120}$ Although the earthquake initially disrupted meetings at the mission, soon "the meetings were attended by people of every group on the face of the earth." 121

Despite the tremendous initial success of the revival and subsequent mission, there was opposition and competition within their own ranks. Very quickly, some ministers opened up their own missions within blocks of the Azusa Street Mission, hoping to recruit energetic believers from Azusa. Frank Bartleman opened his mission in a former German Pillar of Fire Church at Eight and Maple Street, a mere six blocks from the mission. Another pastor named

\footnotetext{
118 U.S. Geological Survey. "Historic Earthquakes: San Francisco, California. 19060418 13:12:21 UTC, Magnitude 7.8" US Geological Survey, (October, 2009), accessed March 7, 2012. http://earthquake.usgs.gov/earthquakes/states/events/1906_04_18.php.

${ }^{119}$ Bennett Lawrence, The Apostolic Faith Restored, (St. Louis, MO: Gospel Publishing House, 1916), 74.

${ }^{120}$ Frank Bartleman, My Story "the Latter Rain". (Columbia, SC: John M. Pike, 1909), 42. Accessed January $16^{\text {th }}, 2016$. http://www.ccel.org/ccel/bartleman/story/Page_1.html.

121 Dan L. Thrapp, "Pentecostal Sects to Convene Here," The Los Angeles Daily Times (September 9, 1956), III, 11.
} 
Elmer Fisher started a church called the Upper Room Mission less than four blocks from Azusa, which replicated the Azusa method of publishing a Pentecostal paper devoted to news of the movement. ${ }^{122}$ Some of the opposition was racial, and some boiled down to personality differences. The first sign of trouble occurred in 1907 when the owners of the Azusa revival building desired to sell the building. Seymour and the Trustees decided to purchase it for $\$ 15,000$ with $\$ 4,000$ down payment in order to secure their future tenancy. ${ }^{123}$ While most congratulated the leaders, some like Frank Bartleman and Rachel Sizelove criticized Seymour for essentially selling out the movement to institutionalized denominationalism. Contending that "the church was an organism not a human organization" Bartleman wrote "... from that time the trouble and division began." 124 Some white members raised questions about the accounting of funds at the mission, and Seymour responded with the statement that "I sent it out as the Lord told me and as the need required, and before God I never misspent or kept a cent of it." ${ }^{\prime 25}$ The inquiries died down over time but tensions continued to rise over questions of leadership. To compound matters, Seymour married Jennie Evans Moore on May 13th, 1908 without inviting any white coworkers.

\footnotetext{
122 The paper was likewise named after the mission: The Upper Room. Cecil M. Robeck, The Azusa Street Mission and Revival: The Birth of the Global Pentecostal Movement. (Nashville: Nelson Reference \& Electronic, 2006), 94.

123 The Apostolic Faith, February-March 1907, 2.

${ }^{124}$ Bartleman, How Pentecost Came to Los Angeles, 68.

${ }^{125}$ Arthur G. Osterberg. "Oral History of the Life of Arthur G. Osterberg and the Azusa Street Revival." Interview by Jerry Jensen and Jonathan Ellsworth Perkins, March 1966 (4 tapes), Transcription by Mae Waldron, Tapes 1-4, Flower Pentecostal Heritage Center, as quoted in Espinosa, William J. Seymour and the Origins of Global Pentecostalism, 112.
} 
Why they did this is a matter of conjecture. Some scholars suggest that Clara Lum was in love with Seymour and wanted to marry him. Others suggest that the age gap between Seymour and Moore was the source of controversy. ${ }^{126}$ Historian Gaston Espinosa astutely points out that what is most likely is that the marriage did not fit tidily with the mission's end-times message of self-sacrifice and celibacy. ${ }^{127}$ It was once again viewed as settling.

Furthermore, the racial unity that had characterized the mission in its earliest years began to disintegrate. The Articles of Incorporation of the Apostolic Faith Mission (originally filed on April 24th, 1907) were amended on May 19th, 1914 to ensure that the mission "shall be carried on in the interests of and for the benefit of the colored people of the State of California, but the people of all countries, climes, and nations shall be welcome." 128 This move has been viewed by some as a capitulation to some of the more prejudiced black members and by others as outright racial discrimination by Seymour himself. ${ }^{129}$ More likely, Seymour was protecting the mission from white takeover. As years passed, the daughter churches that were founded by evangelists from Azusa coalesced

\footnotetext{
${ }^{126}$ Seymour was thirty-eight and Moore was twenty-five at the time.

${ }^{127}$ Espinosa, William J. Seymour and the Origins of Global Pentecostalism, 113-114.

${ }^{128}$ William Seymour, "Apostolic Faith Mission Amended Articles of Incorporation. Article I." Reprinted in Larry Martin, Ed., The Doctrines and Discipline of the Azusa Street Apostolic Faith Mission of Los Angeles, California. (Joplin, MO: Christian Life Books, 2000), 34.

${ }^{129}$ For a full discussion of the disputes, see Espinosa, William J. Seymour and the Origins of Global Pentecostalism, 109.
} 
around ethnicity. This was likely due to language barriers as well as a shared sense of identity, but it chipped away at the core message of Azusa. 


\section{CHAPTER 3:}

THE APOSTOLIC FAITH AND TRANSNATIONAL PENTECOSTAL PRINT CULTURE

This chapter examines the official organ of the Azusa Street Revival and Mission: the Apostolic Faith. The Apostolic Faith Mission published the periodical with the intention to spread news of the revival to the world. They believed that the revival marked the physical point of the return of Pentecost and the outpouring of spiritual gifts to God's people. Yet the periodical served many critical purposes for the mission. First, it relayed news of the revival. Second, it informed readers of the central tenants of their belief including the important link between Baptism of the Holy Spirit and speaking in tongues. Third, it served as a spiritual extension of the revival to those who could not physically make it to Azusa. Fourth, it created what I will call a 'pneuma network' of Pentecostal believers around the world. Fifth, the magazine served as a medium of exchange among this community of believers. In doing so, it helped to mold the discourse of the young movement. Lastly, by doing all these things, The Apostolic Faith "branded" the movement as Pentecostal. This chapter analyzes the layout and content of the periodical as well as the messages within its pages. The goal of this chapter is to understand how the periodical helped to "brand" the revival as the place of God's new Pentecost, thereby branding the Pentecostal movement as a whole. In this endeavor, this chapter examines the Apostolic Faith from six different perspectives: its origin and history, its physical layout and appearance; 
its content; its purposes both overt and effective; its financing; and finally, its opposition.

Pentecostal periodicals depicted the dramatic growth of Pentecostalism during its critical first few years. The Apostolic Faith remains one of the critical sources for understanding the early years of the movement. Within its pages are hundreds of testimonies, sermons, letters, and reports from the revival. These sources offer glimpses of the people involved in the revivalists and their beliefs. Pentecostal churches have saved and digitized a number of these magazines in an attempt to preserve their history. Scholars of Pentecostalism have long recognized the importance of these periodicals to the movement. Pentecostal periodicals, as historian Grant Wacker notes, "Constituted by far the most important technique for sustaining national and world consciousness." ${ }^{1}$ Historians and scholars have used these periodicals extensively as sources to be mined for insights into the beliefs of the early Pentecostals and tidbits of information about the larger movement, but rarely are these periodicals examined as objects worthy of analysis in their own right. ${ }^{2}$ The Apostolic Faith and the dozens of Pentecostal periodicals that it inspired, should be examined as purposefullydesigned cultural artifacts of their times. They have much to tell us about the first generation of Pentecostals, and the evolution of the movement.

\footnotetext{
${ }^{1}$ Grant Wacker, Heaven Below, 264.

${ }^{2}$ This is a common critique that periodical studies scholars make. See: Sean Latham and Robert Scholes. "The Rise of Periodical Studies". PMLA. 121 (2006): 521.
} 
"PENTECOST HAS COME" read the headline of a brand new religious periodical that hit the streets of Los Angeles in the late summer of 1906. This paper, entitled The Apostolic Faith, was the new product of the Apostolic Faith Mission which had been made famous by the infamous Azusa Street Revival that had started only five months earlier. The Apostolic Faith Mission began printing and distributing The Apostolic Faith in September 1906, publishing a total of fourteen issues on a semi-monthly basis until June $1908 .^{3}$ The editors chose to remain anonymous, as they did not wish to distract attention from the mission, and instead claimed that God was "the editor-in-chief and business manager" of the paper. ${ }^{4}$ "The reason we put no name of editor at the head of this paper is because we want Christ exalted, that in all things He might have pre-eminence," the editors explained. ${ }^{5}$ Unofficially, the editors were William Seymour, the leader of the Azusa Street Revival; Clara Lum, the mission's secretary; and Florence Crawford, a worker at the mission and an early AFM evangelist. ${ }^{6}$ Together these individuals provided the first news of the revival to the world.

\footnotetext{
${ }^{3}$ No issues were released in March, July, August, November or December of 1907. No issues were released in February, March or April of 1908. The last issue was June 1908. There is allegedly a fifteenth issue, but it has never been located. See Grant Wacker, Heaven Below: Early Pentecostals and American Culture. Cambridge, Mass: Harvard University Press, 2003. 42.

${ }^{4}$ The Apostolic Faith, September 1906. 4.

5 The Apostolic Faith, January 1908, 2.

${ }^{6}$ Most Pentecostal scholars agree that Lum was the primary editor of the Apostolic Faith. This is mostly based on the fact that Lum took the mailing lists with her to Portland Oregon after splitting with the Azusa mission. Crawford later joined her there and they continued producing the Apostolic Faith in Portland. Seymour also likely helped with the editing, as his sermons were a common element of the paper and he demanded the lists be returned to him when Lum left so that he could continue publishing the paper. See: James Robinson, Divine Healing: The Years of Expansion, 1906-1930: Theological Variation in the Transatlantic World. (Eugene, OR: Pickwick Publications, 2014), 27. Robins notes that Lum was Seymour's personal secretary. See: R. G. Robins, Pentecostalism in America. (Santa Barbara, CA: Praeger, 2010), 37. Cecil M.
} 
The Apostolic Faith paper drew inspiration from the holiness periodicals of nineteenth-century America. In the nineteenth century, America was awash in religious print culture. As discussed in the first chapter, radical sects often emerged via religious literature. Sect leaders often grew their movements by transmitting their ideas in religious periodicals. One of the largest and most important religious print networks of the late nineteenth century was that of the independent holiness churches. Publishers wielded immense influence as the regularity of the periodical substituted the ritual of the church meeting in the lives of some believers. Itinerant evangelists gained notoriety through their articles in such publications, and the common believer had access to a regional community of religious thought and events. William Seymour had come into contact with several holiness publishers prior to his arrival in Los Angeles, and was thus well aware of the importance of print in establishing a religious following.

Although inspired by holiness periodicals, the Apostolic Faith struck its own trend in both physical layout and appearance. Directly underneath the bold title "The Apostolic Faith" was their rallying cry: "'Earnestly contend for the faith which was once delivered unto the saints.'--Jude 3."7 The word "earnest" perfectly encapsulated the theme of the paper throughout its run. The editors chose a news-oriented approach over that of a casual literary periodical. The editors of the Apostolic Faith printed their paper in the four-column style of a

Roebeck notes that Lum had prior experience working as an editor with the Missionary World, a publication of the World's Faith Missionary Association. See Cecil M. Robeck, The Azusa Street Mission and Revival: The Birth of the Global Pentecostal Movement. (Nashville: Nelson Reference \& Electronic, 2006), 305.

${ }^{7}$ Jude $1: 3$. This verse was printed on the front page of every issue. 
newspaper complete with headlines. ${ }^{8}$ With the exception of the February-March 1907 issue, every issue was four pages long. The pages were large $11 \times 15$ inch dimensions but the editors filled every millimeter of space no matter how small the gap. This resulted in an approximate average of 19 sections per page. ${ }^{9}$

The newspaper-style format had several advantages over the more literature-oriented two-column layouts typical of Holiness and healing periodicals of the time. First, it emphasized the urgency of news of the movement. The AFM desired to show that they were at the center of a massively growing movement. The brief, but numerous testimonials, letters, and reports gave the impression of a large, dynamic movement. With no images to distract the eye, all attention was on the short bursts of textual information that conveyed news of the latest revivals and miraculous events. It was a departure from the slow, cathartic reading of church periodicals which emphasized literature and had as their foundation heavy theological articles and verbose sermons. Second, it kept the information fresh and newsworthy. There was no set column in the paper everything was new from month to month. Although the Apostolic Faith featured intermittent reproductions of Seymour's sermons and the occasional article, the bulk of the contents of the paper was devoted to local, regional, and international news of the movement, and the testimonials of believers. Most testimonials in The Apostolic Faith were quite short - often only a few lines - and the focus was

\footnotetext{
8 The December 1906 issue had five columns.

${ }^{9}$ I came to this number by taking the average of the sections - be they large articles or tiny blurbs - for all the pages.
} 
not so much on the individual but on the sheer numerical amount of testimonials in the paper. This was a paper that was meant to be consumed eagerly and passed on. Third, it allowed the editors a great deal of editing discretion when compiling the paper. Every crack of the text space was filled in the Apostolic Faith, even if just to fill the corner with the statement "It is impossible to put all the good reports and testimonials into this paper." 10

The content of the Apostolic Faith remained remarkably consistent over its run. Each issue contained several elements: testimonials, missionary reports, letters, sermons, spiritual statements, and theological articles. A few issues contained poetry, songs, and hymns. The largest categories were the testimonials and missionary reports, which occasionally overlapped. These were often heavily edited to include what the editors found to be the most important elements. Missionary reports were often headed with "Pentecost in [place]."11 A typical front page was dedicated to news about where the movement had spread. For instance, the January 1908 issue featured twenty-three letter excerpts from believers in fourteen states, Canada, and India. Most were brief excerpts such as, "God is working in this place. Five of us have the baptism, speaking in tongues and others getting hungry. He came in to abide with me on Oct. $16^{\text {th }}$ and spoke for Himself." 12

\footnotetext{
10 The Apostolic Faith, September 1907, 4.

11 "Pentecost in the South," "Pentecost in San Francisco," "Pentecost in Denver," and "Pentecost in Spokane, Wash." The Apostolic Faith, April 1907, 4.

12 The Apostolic Faith, January 1908, 1.
} 
The purpose of the Apostolic Faith fell into two categories, the overt and the implied. The editorial staff often made explicit arguments from its pages. Two editions, of June 1907 and January 1908 illustrate this idea.

The primary goal of The Apostolic Faith was to relay news of the revival in Azusa to the world. This paper announced the revival to the nation, declaring that "Pentecost has come" on the front page of its first issue in September 1906. The subtitle indicated that this was an authentic recurrence of the outpouring of the Holy Spirit from the first Pentecost: "Los Angeles Being Visited by a Revival of Bible Salvation and Pentecost as Recorded in the Book of Acts." 13 They emphasized that the revival was indeed the return of Pentecost, as describe in the book of Acts. The first four issues' lead title all contained the word "Pentecost." They saw the revival as a culmination of a long spiritual trajectory:

All along the ages men have been preaching a partial Gospel. A part of the Gospel remained when the world went into the dark ages. God has from time to time raised up men to bring back the truth to the church. He raised up Luther to bring back to the world the doctrine of justification by faith. He raised up another reformer in John Wesley to establish Bible holiness in the church. Then he raised up Dr. Cullis who brought back to the world the wonderful doctrine of divine healing. Now He is bringing back the Pentecostal Baptism to the church. ${ }^{14}$

The editors sought an audience from among the radical holiness groups of the day that believed they were living in the end times and searching for signs of the return of Christ. The Apostolic Faith thrived off of the sense of apocalypticism within American Protestantism during this period and especially among come-

${ }^{13}$ The Apostolic Faith, September 1906. 1.

${ }^{14}$ The Apostolic Faith, 10/06, 1. 
outer groups. ${ }^{15}$ These Protestants were waiting for news of something that would herald the return of Christ, and the Apostolic Faith Mission was focused on reaching this audience. They published many hymns in the newspaper which captured the premillennial emotions of the time with titles like "Jesus is coming," "A Message Concerning Christ's coming," "When Jesus Comes," "The Signs of the Times," and "The Warfare, the Rapture, and the Afterwards."16 Readers found within the pages of the Apostolic Faith reading material that fed into millennialist beliefs. Many articles were devoted to emphasizing the imperative nature of evangelism and explaining premillennialist beliefs. The very first issue of The Apostolic Faith contained a section explaining the Millennial:

All these 6,000 years, we have been fighting against sin and Satan. Soon we shall have a rest of 1,000 years. We are going to rest from our 6,000 years of toil in a reign of 1,000 years. That will be the millennial age (Jude $14,15)$. The saints who have part in the first resurrection will return with Jesus and reign over unglorified humanity. (Rev. 20:4). Our place will be higher than the angels, because we are partakers of His divine nature and His immortality, and angels are simply pure spirits. We can go and come, just as Jesus did when He rose from the dead. We can vanish out of sight and go millions of miles in a second... We shall be "like unto His glorious body." (Phil. 3:21). We shall have the same privilege as He had, for "we shall be like him." We shall shine forth as the sun in the kingdom of our Father. We shall be in the heavenly image."17

The paper utilized end-times language to illustrate what they saw as the outpouring of God's Spirit during the last days. The revivalists believed that this Pentecost was the new age, and that Christ was using them to save souls before

\footnotetext{
${ }^{15}$ See Matthew Avery Sutton, American Apocalypse: A History of Modern Evangelicalism. (Cambridge, MA: Belknap Press of Harvard University Press, 2014), 2-7.

${ }^{16}$ See "A Message Concerning His Coming," The Apostolic Faith, Oct., 1906; Dec., 1906, 4; Jan 1907, 2; Feb-March, 1907, 4; April 1907, 3; May 1907, 2 - 3; Sep., 1907, 4.

17 The Apostolic Faith, September, 1906, 3.
} 
his return, which could be at any moment. The duel icons of fire and rain were employed extensively throughout the text. The Holy Spirit was often associated with fire, and the blessings of God as rain. "All over this city, God has been setting homes on fire and coming down and melting and saving and sanctifying and baptizing with the Holy Ghost" wrote the editors in the first issue. ${ }^{18}$

As with other newspapers, the main goal of The Apostolic Faith was to inform. While other religious periodicals focused on sermons or articles relating to doctrine, the editors of The Apostolic Faith were far more interested in producing a paper that informed the reader of what was spiritually happening in the larger world. Text was the main element of the paper, as it was devoid of reprinted photos, images, or drawings. The only exception was the inclusion of a hymn with music notes in the September 1907 issue. ${ }^{19}$ There were occasional poems or songs printed in the paper, but the vast majority of pages were devoted to three elements: testimonials, sermons, and letters. All three of these elements were news-oriented in that they served to emphasize the growth of the movement. Despite the overabundance of text, the pages were relatively easy to read, as the editors expertly wove edited bits of letters and reports in and around longer pieces of writing. As an example, the front page of the second issue contained the following: a brief historical sketch of the roots of the movement, three brief blurbs about various missionaries who had left for foreign lands, five reports of healing (including cancer, epilepsy, and insanity), and four extensive

\footnotetext{
18 The Apostolic Faith, September 1906, 1.

${ }^{19}$ The Apostolic Faith, September 1907, 4.
} 
testimonies from Azusa Street participants including a former Nazarene preacher, a Portuguese minister Adolph Rosa, and Julia Hutchins and her niece Leila McKinney. ${ }^{20}$

The task of conveying the central doctrines of the young movement fell most visibly on William Seymour, and were echoed by the nameless editors throughout the pages of the paper. Seymour laid out what he understood as the five elements of atonement ${ }^{21}$ in the first issue, saying "We that are the messengers of this precious atonement ought to preach all of it, justification, sanctification, healing, the baptism with the Holy Ghost, and signs following."22 This would become known as the "full" gospel, and was based on Romans 15: 18-19, in which Paul declares "For I will not dare to speak of any of those things which Christ hath not wrought by me, to make the Gentiles obedient, by word and deed, Through mighty signs and wonders, by the power of the Spirit of God; so that from Jerusalem, and round about unto Illyricum, I have fully preached the gospel of Christ." ${ }^{23}$ William Seymour authored most of the longer sermons and spiritual articles. ${ }^{24}$ The editors frequently published Seymour's sermons on a

20 The Apostolic Faith, October 1906, 1.

21 "Atonement" references the process by which an individual may be reconciled to God.

22 William Seymour, "The Precious Atonement," The Apostolic Faith, September 1906, 2.

${ }^{23}$ Romans 15: 18-19, King James Version. The term "full gospel" is a reaction to cessationism which argued that the spiritual gifts as described in the New Testament had ceased with the end of the original Apostles. Holiness-Pentecostal traditions believe that they continue in the present day, and thus they claim to preach a "full" gospel.

${ }^{24}$ Ronald Kydd, Finding Pieces of the Puzzle: A Fresh Look at the Christian Story. (Eugene, Oregon: Wipf \& Stock Publishers, 2011), 236. 
variety of topics ranging from to repentance to adultery. In doing so it helped to mold the movement's discourse and institutionalize the theology.

The theology of tongues as evidence of Holy Ghost Baptism was novel and poorly understood, so the paper's editors carefully controlled the message in each issue. Drawing from several passages in the biblical books of Mark, John, Joel, and Acts, Seymour argued that "the speaking in tongues was the sign or evidence to Peter that the gentiles had received the Holy Ghost." ${ }^{25}$ Seymour articulated that the gift of tongues was available to all believers and advocated that it should be evidenced in the church. To receive the gift, Seymour advanced the idea that the believer should "tarry" for it. ${ }^{26}$ "Tarrying" was a very common expression used by those in the movement and explains why claims of Holy Ghost Baptisms occurred frequently during prayer meetings. ${ }^{27}$

Published testimonials frequently emphasized Holy Ghost Baptism. As the cornerstone of the doctrine of the Apostolic Faith Mission, it makes sense that the editors would choose to emphasize these accounts. Nearly every page of the paper contained an account of someone who received "their Pentecost." This phrasing indicated that Pentecost was not simply a geographically-specific event, but also an intimate experience to be had by those who sought it out.

25 The Apostolic Faith, September 1906, 2.

26 To "tarry" meant to seek through earnest prayer.

${ }^{27}$ A word count of the variations of "tarry" yields approximately 51 results over the course of 13 issues. 
Occasionally the editors would include the individual's name. The editors promoted a demographic mixture of accounts:

Bro. Campbell, a Nazarene brother, 83 years of age, who has been for 53 years serving the Lord, received the baptism with the Holy Ghost and gift of tongues in his own home. His son, who was a physician, was called and came to see if he was sick, but found him only happy in the Lord. Not only old men and old women, but boys and girls, are receiving their Pentecost. Viola Price, a little orphan colored girl eight years of age, has received the gift of tongues. ${ }^{28}$

Accounts like this one promoted several ideas at once. This statement promoted the idea of the "democracy of the Spirit," it supports the notion that people from other denominations were converting to the movement, and it emphasized the practice of tongues as evidence that these individuals were Holy Ghost Baptized.

The financial funding for the paper reflected the Pentecostal's belief that the movement was "Spirit led." The Apostolic Faith Mission did not practice soliciting subscriptions from its members, but instead relied on them to offer donations they felt called. This practice was integral to the Pentecostal movement. One of the Pentecostals' biggest criticisms of the institutionalized religion was materialism and money. The title headline containing the date, location and issue number also contained the line "Subscription Free." The editors reinforced this principle often in the paper, noting that the paper was "published free by faith." 29 Notably, the paper lacked advertisements, with the obvious exception of itself. The editors explained:

\footnotetext{
28 The Apostolic Faith, September 1906, 1.

${ }^{29}$ The Apostolic Faith, December 1906, 2.
} 
We have no advertisements - nothing to advertise but this wonderful salvation that is free to all. The writers and workers in the office live by faith outside of what comes for the paper, and we publish no names of editors. All work to the honor and glory of God. This we believe will be a real protection to this paper to keep it pure, for unless one is filled with the love of God they do not covet to work without honor or money. ${ }^{30}$

The mission leaders used the humble beginnings of the revival as evidence of God's work. The Pentecostals often compared the mission at Azusa Street to the stable where Christ was born for its lowly origins. ${ }^{31}$ Those who felt called to leave for the foreign mission fields would often sell all they had and trust in God to provide support for their endeavors. The editors were quick to explain that there was no official tithing at Azusa, but that people simply gave as they felt called, which was enough to run the mission and publish the periodical as necessary:

When Pentecostal lines are struck, Pentecostal giving commences. Hundreds of dollars have been laid down for the sending of missionaries and thousands will be laid down. No collections are taken for rent, no begging for money. No man's silver or gold is coveted. The silver and the gold are His own to carry on his own work. He can also publish his own papers without asking for money or subscription price. ${ }^{32}$

According to the editors, it cost approximately $\$ 200$ to print 40,000 copies of The Apostolic Faith. ${ }^{33}$ They did not go into debt over the paper, but only printed it as the money came in. ${ }^{34}$ They were able to print 5,000 copies of the first issue,

\footnotetext{
30 The Apostolic Faith, December 1906, 2.

${ }^{31}$ The Apostolic Faith, November 1906, 1.

32 The Apostolic Faith, September 1906, 1.

${ }^{33}$ The Apostolic Faith, May 1907, 2.

34 The Apostolic Faith, September 1906, 4.
} 
10,000 of the second, and 30,000 of the third issue.$^{35}$ Once the paper was in circulation, subscribers would send in contributions as they felt called. Unfortunately, the mission did not keep records of the donors, saying "He says that those who give in secret He will reward openly." ${ }^{36}$ Although advancements in printing technology made it cheaper than ever to produce mass print, it was still costly to print thousands of periodical copies and mail them. In November 1906 the mission claimed that it cost approximately $\$ 1$ to print and mail 100 copies of the four-page paper. ${ }^{37}$ To decrease costs even further, groups would purchase their own presses. This required a substantial amount of startup money, but if the periodical was successful, it had the potential to reap large financial gains. A secondhand printing press could be obtained for approximately $\$ 175.00$ in the US. ${ }^{38}$ Adjusted for inflation, this was approximately $\$ 4,640 .{ }^{39}$ To make the publication as efficient as possible, the editors asked often that the reader not "waste" the paper but instead "pass it on" to others so that it might reach as many as possible. ${ }^{40}$

\footnotetext{
35 The Apostolic Faith, November 1906, 3. In November, they claim they only printed 20,000 of the third issue, but in the December issue they claimed they were able to print 30,000 as well as 30,000 of the December issue. See The Apostolic Faith, December 1906, 2.

${ }^{36}$ The Apostolic Faith, November 1906, 3.

37 The Apostolic Faith, November 1906, 3.

38 The Pentecost, Oct-Nov 1908, 6.

${ }^{39} \mathrm{~A}$ simple purchasing power calculator would say the relative value is $\$ 4,640.00$. This answer is obtained by multiplying $\$ 175$ by the percentage increase in the CPI from 1908 to 2014 . http://www.measuringworth.com/uscompare/relativevalue.php

40 The Apostolic Faith, May 1907, 2.
} 
The editors relied on a preexisting network of Holiness periodicals in particular to spread news of the revival via The Apostolic Faith. In his travels, Seymour had met some of the editors of these publications and therefore had knowledge of how important they were for the young movement. Although the networks existed, The Apostolic Faith was started without a pre-established mailing list, a fact that historian Douglas Nelson points out as something of a miracle in and of itself. ${ }^{41}$ Instead, the revival provided the mass of individuals who left their contact information in order to subscribe to the periodical.

Over time the paper became more international in scope. This element of the paper helped to emphasize the place of Azusa in the global Pentecostal movement. The first paper went out in September 1906, only five months after the initial outbreak at Azusa, and it consistently notes the international flavor of the revival's participants. Some, like the Meads, a missionary couple working in Central Africa, had traveled across the Atlantic and U.S. "to get their Pentecost." ${ }^{2}$ Others claimed to have been Holy Ghost Baptized and were leaving for faraway lands where they believed they were sent to preach the gospel with their new gift of tongues. In the first issue, a trio of missionaries consisting of Andrew Johnson, Louise Conduit, and Lucy Leatherman left for Jerusalem, spreading the news of the revival at their stops along the way in the United States. The mission reported that:

\footnotetext{
${ }^{41}$ Nelson, For Such a Time As This, 79.

42 The Apostolic Faith, September 1906, 3.
} 
Bro. Johnson has received seven different languages, one of which is the Arabic. Sister Leatherman speaks the Turkish language, and while in Oakland, some were talking on the street about the gift of tongues, Sister Leatherman began to speak just as a man wearing the Turkish fez came by. He listened in wonder and asked what college she had attended, saying she spoke the most perfect Turkish tongue he had heard spoken by a foreigner. He was an educated man from a Turkish college in Constantinople. She told him the Holy Ghost gave her the language which she did not understand herself and he was the first person that had interpreted for her. ${ }^{43}$

The editors linked the global spread of the revival with the end times, saying "This is a world-wide revival, the last Pentecostal revival to bring our Jesus. The church is taking her last march to meet her beloved." ${ }^{4}$ In the January 1907 issue, the editors rejoiced over the spread of Pentecost in both hemispheres. In March the lead title read "Pentecost Both Sides the Ocean." 45

The mission's periodical was an extension of the revival itself. Beginning in September of 1906, and lasting until May 1908, the Los Angeles group published thirteen issues of the periodical to thousands of churches and homes across the country. ${ }^{46}$ The first print run consisted of 5,000 copies ${ }^{47}$ It worked first as advertisement for the revival, informing vast swaths of readers about the revival and the miraculous events taking place in Los Angeles. A.W. Orwig, a visitor to the revival in 1906, wrote:

A large four-page paper was issued by the mission, a copy of which accidentally or providentially fell into my hands on a Friday afternoon. At

\footnotetext{
${ }^{43}$ The Apostolic Faith, September 1906, 3.

44 The Apostolic Faith, September 1906, 4.

45 The Apostolic Faith March 1907, 1.

${ }^{46}$ The original thirteen issues are available in digital format from the Flower Pentecostal Heritage Center. There are rumors of two more issues, but no extant copies appear to exist.

47 The Apostolic Faith, September 1906, 4.
} 
once I began to read it with considerable interest, and in a very short time was convinced that God was in the work. I continued to read nearly all day Saturday until my heart burned within me, and I said to my wife, "I am going to Azuza Street mission on Sunday and see and hear for myself. ${ }^{48}$

As an object, the periodical was viewed as both an object of advertising and an object imbued with spiritual significance. Writing about the importance of the paper to the movement, the editors wrote:

Some who learned of the Pentecost in Los Angeles through reading this have come to Los Angeles and received the baptism with the Holy Ghost and the Bible evidence as received on the day of Pentecost. One received the Holy Ghost and gift of tongues while reading the first number of the paper. May the Lord continue to bless these printed messages to souls. We expect the Spirit to accompany this paper to the heart of each reader. ${ }^{49}$

Letters from subscribers indicate that many felt as if the periodical physically extended the power of Pentecost to readers. Mission workers would lay hands on and pray over the copies of the newsletter as they folded and mailed them out. ${ }^{50}$ The editors explained, "Requests for prayer from hungry souls are coming in from all over. They want salvation from sin, and sanctification, and the baptism with the Holy Ghost, and healing of their bodies. So the requests are presented and handkerchiefs are blest and the power of God comes upon us in praying for them; and we receive letters saying that they are receiving their Pentecost and being healed." ${ }^{21}$ The Apostolic Faith, and the newsletters that followed in its wake were instrumental in creating a global body of Pentecostal

\footnotetext{
48 The Weekly Evangel, March 18th 1916, 4.

49 The Apostolic Faith, November 1906, 4.

${ }^{50}$ Fred Corum, Word and Witness, 1936. Reprinted in Larry E. Martin, Saved and Sanctified, (Joplin, MO: Christian Life Books, 2005), 72.

51 The Apostolic Faith, February-March, 1907, 1.
} 
believers. The success of the mission and larger movement was predicated on its global growth. Therefore, The Apostolic Faith emphasized this growth predominantly in every paper.

The most important legacy of The Apostolic Faith was its ability to create and maintain a community of believers in what I term a "pneuma network." The Apostolic Faith Mission served as the central hub for this network, which served to foster communication and funding through a vast web of missionaries, laypeople, pastors, and evangelists. While news reports from the revival and the editorials were often nameless, published letters and reports from missionaries more often included physical addresses to which readers could send letters of encouragement or funding. Since missionaries and evangelists often moved around, the editors at the mission accepted donations on their behalf until they could be located again.

The Apostolic Faith featured republished letters which served to foster a sense of community for the fledgling movement. The editors frequently commented on the tremendous number of letters they received, "sometimes as many as fifty per day," they noted in January $1907 .{ }^{52}$ The editors accepted, published, and featured letters from housewives just as often as pastors. Missionaries were given prominence, especially in the later issues, and their published letters and prayer requests gave a personal impression of the movement's swelling ranks. People often wrote in to ask for prayer, or to offer

52 The Apostolic Faith, January 1907, 4. 
testimony of their divine healing or Holy Ghost baptism. Employing terms like "brother" and "sister," the editors used the language of familial ties to emphasize the movement as that of a growing family of believers, and reiterated that "The sweetest thing of all is the loving harmony. Every church where this has gone is like a part of the family." 53

It was clear from the beginning that missionaries were one of the chief priorities of the paper. The editors promised in the first issue that "Hundreds of workers and missionaries will be represented in it." ${ }^{54}$ Missionaries physically spread the movement across the globe, and the paper served as the organ of their work. Missionaries wrote in frequently to the editors and their letters and reports were reprinted in the pages of The Apostolic Faith. The missionary reports served the crucial purpose of showing the readers the global growth of the movement. Some scholars suggest that the paper overstated its impact. Wacker, for instance suggests that early Pentecostal periodicals "created the impression that Pentecostals were triumphing everywhere." ${ }^{55}$ Unlike the testimonials, missionary reports almost always included the names of the missionaries and not infrequently their known addresses. This allowed subscribers to send money and letters of encouragement directly to the missionaries. The editors also frequently reminded readers that they could sent their funds and letters to the Apostolic Faith Mission publishing office and they

\footnotetext{
53 The Apostolic Faith, November 1906, 1.

54 The Apostolic Faith, September 1906, 4.

${ }^{55}$ Wacker, Heaven Below, 264.
} 
would be forwarded. This was necessary because the editors claimed that "God is solving the missionary problem, sending out new-tongued missionaries on the apostolic faith line, without purse or scrip, and the Lord is going before them preparing the way." 56

Missionary letters provided some of the most powerful defenses of the "democracy of the Spirit" trope that the Azusa Street Mission advocated in The Apostolic Faith. Thomas Hezmalhalch's letter to the Azusa street mission, published in the January 1907 issue of the Apostolic Faith, serves as an example of how this theology manifested outside the physical confines of the Azusa Street Mission. Hezmalhalch was a seasoned evangelist and missionary. He was one of the early leaders at the mission, and would later join John G. Lake to take Pentecostalism to South Africa. In 1907 the mission was particularly proud of their work among the Mojave Indians in Needles, California. Hezmalhalch traveled to Needles for the start of the New Year in 1907. He began his letter explaining that the Mojave tribe was "fast dying out" due to a lack of desire "to improve their condition. ${ }^{57 "}$ Yet, when they converted, they "at once begin to get up and build themselves homes, and cease from the evil practices and habits of the tribe life." 58

Like many other missionaries of his time, Hezmalhalch equated conversion to Christianity with Western civilization. During his visit to a Sunday

\footnotetext{
56 The Apostolic Faith, November 1906, 2.

57 The Apostolic Faith, January 1907, 3.

58 The Apostolic Faith, January 1907, 3.
} 
service, Hezmalhalch reported that there were "thirty Indians in the mission besides the white people." An Indian pastor preached, saying "God-Holy Ghost talk through us to all the Indians in the mountains, like Holy Ghost talk through that brother... And God Jesus make all Indians in mountains, and us, and these, and these all big Holy Ghost tribe." Hezmalhalch wrote, "there are thousands of Indians of different tribes in the mountains, and he [the Mojave pastor] meant they and themselves, and the white people, and a colored brother, pointing to each of us, would, by the blood of Jesus Christ, be made one great spiritual family." 59 This emphasis on interracial unity was a common feature in missionary letters, and served to both inspire adherents and brand the movement as distinct among other religious sects. Hezmalhalch concluded his letter with a plea for more helpers: "Dear saints, will you pray for God to equip some one or more to go into this most wonderful field at our own door? It is foolishness to think God cannot fit up those He sends out to preach His Gospel, with the material and ability to accomplish His will." ${ }^{\circ 0}$ Such letters accomplished several goals at once: they informed readers of news of the movement, fostered the sense of a growing community of believers, reaffirmed core Pentecostal doctrines, and serves as recruitment mechanisms for believers who felt called to serve.

The Apostolic Faith was a medium of exchange among this community of believers. Through the paper believers exchanged ideas and news about the

\footnotetext{
59 The Apostolic Faith, January 1907, 3.

60 The Apostolic Faith, January 1907, 3.
} 
movement, and in doing so contributed to a growing sense of Pentecostal identity. Testimonies served as the backbone of the paper. These were the witnesses of the movement whose testimonies fueled interest and offered verification of the leaders' claims. Once again, these testimonies served as an extension of the revival. Part of the revival meetings included testimonials and people which according to one participant, "often continue for two hours or more and people are standing waiting to testify all the time." ${ }^{61}$ Through the medium of print, testimonials took on new life. The Apostolic Faith published hundreds during its run. Many of these were of people claiming to have been divinely healed. Because of the sheer number, the editors typically cut testimonials down to two or three sentences that included the ailment, "proof" of healing, and a brief statement of praise and faith. Not infrequently the editors would note that the illness was beyond the help of doctors. ${ }^{62}$ Such testimonies of healing fit in well with traditional holiness and healing groups, but the Azusa Pentecostals gave them an urgency that other healing periodicals lacked. These healing testimonials served as proof of a larger movement.

The Apostolic Faith frequently included poetry and songs by various authors which contributed to the formation of a Pentecostal identity. Testimonials reveal that Baptism of the Holy Spirit was sometimes accompanied by claims of receiving poems from God or being endowed with the gift of music or song.

\footnotetext{
61 The Apostolic Faith, November 1906, 1.

62 For instance see: The Apostolic Faith, September 1906, 3.
} 
Music was integral to the Pentecostal movement from its infancy, and songs helped to unify the believers around common themes. Some songs, such as "The Comforter has Come," "Heavenly Sunlight," and "Under the Blood" were reportedly sung at every meeting at Azusa. ${ }^{63}$ These were common WesleyanHoliness hymns that emphasized the return of Christ, sanctification, and atonement. ${ }^{64}$ Yet as the movement grew, The Apostolic Faith editors began publishing new hymns and poetry from those within the movement which emphasized more specific elements of Pentecostal theology. As scholar Melissa Archer notes in her analysis of Pentecostal periodicals, these entries often were filled with apocalyptic imagery. ${ }^{65}$

The song "Baptized in the Holy Ghost" by San Diego Pentecostal Pastor F.E. Hill, illustrates the central theme of the Pentecostal doctrine:

Do you long to be full of joy and free, To be strong in God and his glory see, Then obey His word and you shall be, Baptized with the Holy Ghost.

CHORUS.

"Ye shall be baptized," Jesus said, Baptized with the Holy Ghost.

Tarry then until with the power endued,

63 The Apostolic Faith, November 1906, 1.

64 "The Comforter Has Come" was written by Francis Bottome (1823-1894), a Methodist pastor, in the late 1800s, and was popular in Holiness circles. Likewise, "Heavenly Sunlight" was published in 1899 by Henry J. Zelley (1859-1942), a Methodist pastor. Finally, "Under the Blood" was written by Eli-za E. Hew-itt (1851-1920), who in addition to her work as a hymnist worked as a Sunday School superintendent at the Northern Home for Friendless Children in Philadelphia, Pennsylvania. See http://www.hymnary.org/ and http://cyberhymnal.org/ for more information.

${ }^{65}$ Melissa L. Archer, "The Worship Scenes in the Apocalypse, Effective History, and Early Pentecostal Periodical Literature," Journal of Pentecostal Theology 21 (2012) 87-112. 90. 
Baptized with the Holy Ghost.

Yes l'll be baptized with His power, Baptized with the Holy Ghost.

'Tis the gift I see, Father's promise to me, Baptized with the Holy Ghost.

Will you consecrate to Him now your all, Let Him have his way while to Him you call, As in faith you wait the power will fall, Baptized with the Holy Ghost.

"This is that" which fell at Pentecost, To prepare the church to redeem the lost, We must then be filled at any cost, Baptized with the Holy Ghost.

'Tis the gift of God to the sanctified, He will comfort, lead and will be our guide, And will dwell in us, coming to abide, Baptized with the Holy Ghost.

Will you gladly fall at the Saviour's feet, Give your doubtings o'er, and be made complete, There to dwell in peace, and communion sweet, Baptized with the Holy Ghost.

You can sing God's praise now, and by and by, Ye shall speak with tongues, and shall prophesy, In the power of God ye shall testify, Baptized with the Holy Ghost. ${ }^{66}$

Songs and hymns helped to espouse complex doctrinal ideas in common language. This particular hymn explained the doctrine of Holy Ghost Baptism in terms that were simple enough for children. Communal singing helped to foster a sense of "togetherness" around an identity rooted in Pentecostalism.

The Apostolic Faith was critical to the emergence of Pentecostalism as a brand of faith in the crowded religious sphere of twentieth century America. It not

${ }^{66}$ F.E. Hill, "Baptized in the Holy Ghost," The Apostolic Faith, December 1906, 2. 
only served to form Pentecostal identity but the paper was the primary evangelical weapon of the movement. By publishing The Apostolic Faith, the Azusa Street Pentecostals entered a fierce battleground of religious print culture. They were prepared. They first faced stiff competition from other more established religious sects which had greater connections.

The religious presses ranged from incredulous to outright condemnatory in their observations of the young movement. They frequently adopted derogatory terms for Pentecostal groups and members. The following account, published in the Western Christian Advocate, provides one example of a typical response to Pentecostals:

"The pastor of a Church in a neighboring city recently advertised a sermon to be preached on 'Freak Creeds.' When he entered the church at the hour of service he found a large number of the 'Gliggy Bluks' ensconced in the more prominent pews. When he began his 'Freak' talk these 'tongue' interlopers set up such a jargon that the police were called and the congregation, with pastor, 'Bluks' and all, were routed. Of all parties concerned in this incident we suspect the police performed the most commendable service." ${ }^{67}$

"Gliggy Bluks" was a common derogatory term used for the Apostolic Faith groups that spread outward from Azusa. The Pentecostals inherited some of the slurs associated with Holiness groups like "holy rollers" and "holy jumpers," but also picked up new terms that focused on their practice of tongues like "gliggy blucks."

To battle criticism, the mission aggressively sought out other presses and publishers to join the Pentecostal cause. In short time, the Apostolic Faith was

${ }^{67}$ Editorial Notes, The Western Christian Advocate. March 4th 1908, 5. 
echoed and amplified in other Pentecostal papers that popped up around the country as the movement advanced. Papers such as Bridegroom's Messenger (1907), Word and Witness (1907), Latter-Rain Evangel (1908), The Pentecost (1908), Evening Light and Church of God Evangel (1910), The Midnight Cry (1911), Christian Evangel (1913), Pentecostal Evangel (1913) and Pentecostal Holiness Advocate (1917) comprised a rapidly growing network that formed the backbone of the movement.

Autobiographies, journals, and letters from contemporary evangelists help to paint a fuller image of how such periodicals were established and operated. James Cheek, publisher of the Herald of Hope, described finding a circulation for a paper as a "mountain" that was impossible to scale. Their first efforts were to advertise to individuals: "When we met people on the street, or anywhere, if we felt led to speak to them, we would ask if they wanted to take a good Christian paper." ${ }^{68}$ As one might expect, "getting single names on the streets was slow," but Cheek believed that God "speeded up matters by letting us get in touch with people who had lists of names." 69 These social-hub people proved crucial to establishing a circulation list. Cheek mentioned two women, one who was able to give him over 250 names and addresses, and another who had traveled worldwide who gave him a list "containing seven or eight hundred names." 70 This

\footnotetext{
68 James Cheek, Footprints of a Human Life: An Autobiographical Sketch of the Life of James Cheek. (Los Angeles, CA: Christ Faith Mission, Inc. 1949), 148.

${ }^{69}$ Cheek, Footprints of a Human Life, 148.

${ }^{70}$ Cheek, Footprints of a Human Life, 149.
} 
method of advertising worked spectacularly. Pastors, evangelists, and ministers traveled from across the US to see what was happening at Azusa. Many Holiness and evangelical publishers attended as well, and those that were convinced of the movement converted their presses, thereby expanding the reach of the movement exponentially.

The Apostolic Faith broadcast news of the "conversion" of other periodicals to the Pentecostal movement. The conversion of these other papers served to legitimize the Apostolic Faith Movement in the eyes of its subscribers, and further illustrate how God was transforming and growing the Pentecostal movement. The editors of The Apostolic Faith frequently announced the start of new Pentecostal periodicals, and reported on the "conversion" of former holiness papers to the Pentecostal movement. In February 1907, the paper announced the start of The Apostolic Light, The New Acts, and The Apostolic Evangel. ${ }^{71}$ Formerly Live Coals, The Apostolic Evange/s editor, J.H. King, a Fire-Baptized Holiness preacher, had been convinced from reading The Apostolic Faith that the Pentecostal message was real, and so changed the name of the periodical to reflect his new-found faith. ${ }^{72}$ In a letter to the editors of The Apostolic Faith, the editors of the new Apostolic Evangel described the change in words that were hardly ambiguous by declaring the periodical "transformed by the Holy Ghost."73 They stated: "God unmistakably revealed to the editorial staff the

\footnotetext{
71 The Apostolic Faith, February-March 1907, 1.

72 Stephens, The Fire Spreads, 198.

${ }^{73}$ The Apostolic Faith, February-March 1907, 1.
} 
unscripturalness of the views they entertained, and entire renunciation of the same took place." 74 The editors emphasized the theological transformation. Formerly, "Speaking in tongues as an evidence of Pentecost was stoutly opposed and rejected." However, the editorial staff claimed they had now seen the light, so to speak. They declared:

Henceforth the paper will be unqualifiedly committed to the truth that Pentecost is evidenced by speaking in tongues, and will forever defend it against all opponents of same, and will publish nothing contrary thereto. All articles, contributions and testimonies in harmony with this view will be published, and all contrary thereto will be rejected. It will be purely a Pentecostal organ, and will be the breathing-place for all who have the baptism of the Holy Ghost in Pentecostal reality. All testimonies of those who do not have it but are seeking it will be published, and all who have the baptism of the Holy Ghost may have free right to its columns from time to time. Its name will be changed in harmony with its change of position, and will be called The Apostolic Evangel. The paper will be kept free from all advertisements, as heretofore. We propose to issue a clean paper or none. ${ }^{75}$

This declaration of theological fealty to The Apostolic Faith provides one example of the centrality of print to the early Pentecostal movement. Bringing other former Holiness periodicals under the umbrella of Pentecostalism exponentially compounded the growth of the movement, as these editorial boards and publishers had large subscriber lists of their own.

The conversion of Gaston Barnabus Cashwell provides one final example of the paramount importance of religious print to the movement. Originally an ordained minister of the Methodist Episcopal Church, G.B. Cashwell (1862-1916) joined the Holiness Church of North Carolina in 1903. After hearing of the Azusa

\footnotetext{
${ }^{74}$ The Apostolic Faith, February-March 1907, 1.

75 The Apostolic Faith, March 1907, 5.
} 
Street Revival in the Way of Faith periodical, he traveled "3000 miles for his Pentecost" in November 1906, where he claimed he received the Spirit baptism. ${ }^{76} \mathrm{He}$ returned to North Carolina, where he conducted services. In a letter to the Apostolic Faith periodical marked January 17th, 1907, Cashwell wrote "Our God is fulfilling His promise and His Spirit is being poured out here in Dunn as never before. Many have come from South Carolina and Georgia and have received their Pentecost and gone back, and there some have received the baptism. The fire is spreading. ${ }^{77 "}$ Cashwell became famous for bringing many of the Southern Holiness groups into the Pentecostal fold, including the FireBaptized Holiness Church, the Pentecostal Free-Will Baptist Church, and the Church of God. ${ }^{78}$ Cashwell began publishing The Bridegroom Messenger in 1907 and because of his broad influence he became known as the "apostle of Pentecost in the South. ${ }^{79 "}$

The Apostolic Faith Mission leaders likewise utilized the local nonreligious press for their benefit. Their tactic was to engage the press and refashion any bad press through their newspaper. They presented the negative press as an attempt by Satan to discredit the movement, and they contended that all press helped their movement even when it was negative. The very first issue of The Apostolic Faith included a description of the situation: "The secular papers have

\footnotetext{
${ }^{76}$ The Apostolic Faith, December 1906, 3.

77 The Apostolic Faith, January 1907, 1.

${ }^{78}$ Espinosa, William J. Seymour and the Origins of Global Pentecostalism, 325.

79 lbid.
} 
been stirred and published reports against the movement, but it has only resulted in drawing hungry souls who understand that the devil would not fight a thing unless God was in it. So they have come and found it was indeed the power of God." 80 They had no lack of negative press.

Rather than fight bad press, the Pentecostals used the press as proof of the legitimacy of their movement. Reprinted letters in The Apostolic Faith told of the many "false reports" published by the local press of the meetings, but typically ended with an anecdote of success in the face of such opposition. ${ }^{81}$ Letters from visitors indicate that they may have been aware of a media bias against the group. A visitor to the revival wrote "Cartoons in the newspapers were my first introduction to this meeting... and I said, this is what I have been praying for years. I was warned by leaders that it was of the devil, but I came and got a touch of heaven in my soul." ${ }^{2}$ Thus any news, even in the form of derogatory cartoons and caricatured depictions worked to bring curious people to the mission. The press was so influential that the editors of The Apostolic Faith had no need to advertise the paper like traditional evangelical magazines. In the second issue they stated "We do not find it at all necessary to advertise the paper, because the news of the work has gone far and wide already." ${ }^{83}$

\footnotetext{
80 The Apostolic Faith, September 1906, 1.

81 The Apostolic Faith, September 1907, 1.

82 The Apostolic Faith, November 1906, 1.

83 The Apostolic Faith, October 1906, 3.
} 
The centrality of The Apostolic Faith to Azusa is evidenced by the loss of the paper in 1908. After Seymour's marriage to Jennie Evans Moore, Clara Lum almost immediately took off to Portland Oregon with the mission's international and national mailing lists, effectively silencing the Azusa Street Mission. ${ }^{84}$ Although the Apostolic Faith Mission trustees demanded the lists be returned, Lum instead began publishing the Apostolic Faith from Portland. This marked the beginning of the decline for the revival, as Seymour was unable to continue publishing the paper without the national and international mailing lists. Seymour would continue to travel throughout the U.S. but without the newspaper the impact of the Azusa Street Revival as a central hub for the growth of the movement rapidly declined. Yet while Azusa Street itself was winding down, Pentecostalism was spreading like wildfire internationally. Critically, in 1908 the spark was just catching fire in South Africa.

84 James Goff, Fields White Unto Harvest, 212. 
CHAPTER 4:

HERALDS OF NEW LIGHT: THE FIRE FALLS ON JOHANNESBURG

This chapter explores the first five years of the Pentecostal movement in South Africa. It begins with an overview of the social, political, and cultural background of the country itself and then investigates the peculiarities of religious life in the territory before the first Pentecostal witnesses arrived in 1908. After examining the current historiography of African Pentecostalism, it offers a new examination of the movement in South Africa. It does so by exploring first, the biographies of the missionaries; second, their replication of the Azusa Street revival in Doornfontein; and third, their mission building project in the territory. It argues that the Africa Pentecostals mimicked the evangelical successes of the Apostolic Faith Mission at Azusa, with particular reference to theology, forms of worship, and critically, their use of print media. The leaders of the mission relied heavily on a transatlantic print network of Pentecostal periodicals to sustain the movement financially and broadcast news of the movement from South Africa. As in the U.S., the Pentecostal evangelists succeeded grandly in spreading their message to South Africans, but the young movement also suffered from similar infighting amongst leaders and eventual racial discord.

While North American Pentecostal historiography has blossomed in the past few decades, the study of the movement in Africa is comparatively understudied. ${ }^{1}$ Part of the reason for this is that Pentecostals and charismatics

\footnotetext{
${ }^{1}$ Some of the most notable works on African Pentecostalism include Ogbu Kalu, African Pentecostalism: An Introduction. (Oxford: Oxford University Press, 2008); Martin Lindhardt, Pentecostalism in Africa: Presence and Impact of Pneumatic Christianity in
} 
are a heterogeneous group that defies easy categorization. Studies of African

Pentecostalism have frequently been absorbed either by global Pentecostal

historiography or by African historiography; the field fails to fit neatly into either. ${ }^{2}$

The debate over the rise of Pentecostalism in Africa follows the pattern of North American Pentecostalism, with scholars from within Pentecostalism typically adhering to a providential outlook on the movement. ${ }^{3}$ Outsider historians and sociologists can likewise be divided into three general camps of thought that all root in functional interpretations of religion; namely social disorganization theory, deprivation theory, and psychological deviant or defective theory. ${ }^{4}$ Others have pointed to religious factors that contributed to the rise of Pentecostalism. Allan Anderson, the most prolific and perhaps astute writer on the subject of Pentecostalism in South Africa, argues that the rise of Pentecostalism can be attributed to the fact that it provided an "African expression of Christianity" that

\footnotetext{
Postcolonial Societies. (Boston: Brill, 2014); and André Corten and Ruth Marshall, Between Babel and Pentecost: Transnational Pentecostalism in Africa and Latin America. (Bloomington: Indiana University Press, 2001). Some excellent examples of regional studies include Paul Gifford, Ghana's New Christianity: Pentecostalism in a Globalizing African Economy. (Bloomington, IN: Indiana University Press, 2004); and David Maxwell, African Gifts of the Spirit: Pentecostalism and the Rise of a Zimbabwean Transnational Religious Movement. (Oxford: James Currey, 2007). Clifton Clarke provides an overview of Pentecostal theology in Africa in Clifton R. Clarke, Pentecostal Theology in Africa. (Eugene, OR: Pickwick Publications, 2014).

${ }^{2}$ Ogbu Kalu has articulated the problems associated with melding Pentecostalism into globalization or mission historiographies. See: Kalu, African Pentecostalism, 3-22.

${ }^{3}$ By "providential" I mean that Pentecostal scholars typically attribute the growth of Pentecostalism to the work of the divine. Some scholars who fall into this category are Vinson Synan, Aspects of Pentecostal-Charismatic Origins. (Plainfield, N.J.: Logos International, 1975); and Lyton Chandomba, The History of Apostolic Faith Mission and Other Pentecostal Missions in South Africa. (Central Milton Keynes, England: AuthorHouse, 2007).

${ }^{4}$ Gerald J. Pillay, 1988. "The Use of Functional-Type Theories in the Study of Independent Christian Movements: A Critique". Neue Zeitschrift Für Missionswissenschaft. 44, no.2 (1988). As cited in Allan Anderson, Bazalwane: African Pentecostals in South Africa. (Pretoria: University of South Africa, 1992), 18.
} 
was desperately desired by Africans in the early twentieth century. ${ }^{5}$ Expanding on this foundation, this chapter examines the Apostolic Faith Mission (AFM), an initially interracial, but eventually segregated mission founded by American Pentecostal missionaries in $1908 .{ }^{6}$ Its history indicates that the appeal of Pentecostalism to South Africans of all backgrounds was influenced by a multiplicity of causes, including religious factors, but its growth was heavily motivated by the successful evangelizing campaigns of the Pentecostals themselves.

${ }^{5}$ Anderson's work is primarily limited to the study of the African Initiated Churches in South Africa, and he is one of the foremost in this field. He also writes as a participant-observer, as he is a Pentecostal himself. Nonetheless, his work is some of the most intellectually rigorous done to date on the phenomenon. Allan Anderson, Bazalwane: African Pentecostals in South Africa. (Pretoria: University of South Africa, 1992), 18. For more on Anderson's work see: Allan Anderson "New African Initiated Pentecostalism and Charismatics in South Africa" Journal of Religion in Africa 35, no. 1 (2005) 66-92; An Introduction to Pentecostalism: Global Charismatic Christianity. (Cambridge: Cambridge University Press, 2004); African Reformation: African Initiated Christianity in the 20th Century. (Trenton, NJ: Africa World Press, Inc., 2001); and "Pentecostals and Apartheid in South Africa during Ninety Years 1908-1998." Cyberjournal for Pentecostal-Charismatic Research, 2000, accessed March $12^{\text {th }}, 2016$. http://www.pctii.org/cyberj/cyberj9/anderson.html.

${ }^{6}$ The early evolution of the movement was initially explored in a 1989 dissertation by Christiaan De Wet. De Wet's dissertation was a church history of the AFM that explored the theology of the mission as well its ecclesiastical structure and practices. See: Christiaan Rudolph De Wet, The Apostolic Faith Mission in Africa, 1908-1980 A Case Study in Church Growth in a Segregated Society. (PhD Diss., Cape Town: University of Cape Town, 1989). It was followed by the official church history of the mission: Isak Burger and Marius Nel, The Fire Falls in Africa: A History of the Apostolic Faith Mission in South Africa : a Centennial Edition 1908-2008. (Vereniging: Christian Art Publishers, 2008). Prior to the 1990s much of the historiography on Christianity in Africa tended to focus either on the African Initiated Churches or European missions. The Apostolic Faith Mission falls into a shifting range, as it was neither a fully European mission nor was it an indigenous South African church. Instead, it was an American-founded mission for its first few years before being turned over to its white, predominantly Afrikaner members. The AFM drew heavily from Black Zionist Churches and the Dutch Reformed Church, and yet the mission remained theologically and culturally rooted in American Pentecostalism, making it a hybrid that defies easy classification. For much of its history it was also a segregated church, so although it had a higher number of black members than whites, they communed in separate churches, making a consolidated history unwieldy. See: Andreas Heuser, "'Africa Always Brings Us Something New': A Historiography of African Zionist and Pentecostal Christianities". Religion. 45 (2015): 153-173. 162. 
When the group of American Pentecostals arrived in South Africa in 1908, they entered a dynamic and turbulent environment, wracked by warfare, and undergoing massive population shifts. During the min-nineteenth century the region was divided into provinces that included British colonies, Afrikaner settled states, and African states. By 1908 the country was comprised of four separate British colonies which would be united as the Nation of South Africa in $1910 .^{7}$ The Cape Colony covered roughly half of the country, encompassing the entire south-western portion of the Cape Peninsula. The Orange River Colony lay to the northeast and had existed as a sovereign Boer republic from 1854 to 1902, when it was annexed by the British during the South African War. The area known as the Transvaal ${ }^{8}$ extended to the north, in between the Vaal River to its south and the Limpopo River to the north, and the Kalahari Desert to the west and Natal to the east. The colony of Natal, annexed by the British in 1843, lay on the eastern edge of the country, bordering all three other colonies and the Indian Ocean.

Nineteenth-century South Africa was home to dozens of indigenous groups that together comprised the vast majority of the people in the country, making it unique in the British colonial empire. According to the 1904 census,

\footnotetext{
7 The term South Africa was employed since the 1830 s as a geographical reference to the territories stretching from the Cape peninsula to the Zambezi River in present-day Mozambique. Robert Ross, Anne Kelk Mager, and Bill Nasson, eds. The Cambridge History of South Africa. 1st ed. Vol. 2. (Cambridge: Cambridge University Press, 2011). Cambridge Histories Online. Web. February $8^{\text {th }}$, 2016. http://dx.doi.org/10.1017/CHOL9780521869836. 18; and David E. Omissi and Andrew S. Thompson. The Impact of the South African War. (Houndmills, Basingstoke, Hampshire: Palgrave, 2002), 77-78.

8 Transvaal meaning: "across the vaal"
} 
"blacks" comprised $67.5 \%$ of the estimated population of $5,175,463$ people. ${ }^{9}$ This population was further divided among a wide range of ethnic groups, based on kinship, dialect, religion, patterns of habitation, and cultural practices. The major ethnic groups of this period were Khoisan, which included the Khoikhoi and the San; the Nguni people, which included the Zulu, Xhosa, Ndebele, and Swazi; the Sotho people, comprised of Northern Sotho (Bapedi), Southern Sotho (Basotho) and Tswana; the Shangaan Tsonga (an amalgam of Nguni and Tsonga groups), and the Venda. ${ }^{10}$ The Nguni peoples tended to live in individual homesteads, while Sotho and Venda peoples tended to live in villages. ${ }^{11}$ The majority of Tswana lived in what would best be described as towns. ${ }^{12}$ The Zulu and the Xhosa constituted the largest ethnic groups, and during the nineteenth century the Zulu emerged as the dominant indigenous polity in Southern Africa. ${ }^{13}$ With the exception of the Khoisan these groups were united in their use of Bantulanguages.

\footnotetext{
${ }^{9}$ W. K. Hancock, Smuts. Vol.1, The Sanguine Years, 1870-1919. (Cambridge: University Press, 1962), 219.

${ }^{10}$ See: Henry Lever, "Ethnicity in South African Society". Humboldt Journal of Social Relations Department of Sociology, Humboldt State University 10, no. 1 (1982): 239-53. http://www.jstor.org/stable/23261866. 249; N.J. van Warmelo, "The Classification of Cultural Groups," in W.D. Hammond-Tooke, ed., The Bantu-Speaking Peoples of Southern Africa, (London, Routledge \& Kegan Paul, 1974), 56-84; and "Race and Ethnicity in South Africa" in South African History Online: Toward a People's History, March 23rd, 2015, accessed January 25th, 2016. http://www.sahistory.org.za/article/race-and-ethnicity-south-africa.

${ }^{11}$ Richard Elphick and T. R. H. Davenport, Christianity in South Africa: A Political, Social, and Cultural History. (Berkeley, Calif: University of California Press, 1997), 121.

${ }^{12}$ Margaret Shaw, "Material Culture," in W.D. Hammond-Tooke, ed., The Bantu-Speaking Peoples of Southern Africa, (London, Routledge \& Kegan Paul, 1974), 86.

${ }^{13}$ Funso Afolayan, Culture and Customs of South Africa. (Westport, Conn: Greenwood Press, 2004), 13.
} 
South African "Coloured" was an ethnic distinction for those born of mixed ancestry between African, European, Asian, and the various indigenous peoples of Southern African such as the Khoisan and Bantu-speaking groups. Unlike the United States, coloured peoples of South Africa held a special, albeit marginal, position within society and were not generally viewed as "black." ${ }^{14}$ Historically, this group resulted from the miscegenation of white European men and native women, particularly the Khoikhoi during the 17 th and 18th centuries. ${ }^{15}$ Like the Boers, they frequently migrated inland from the Cape to escape colonial rule. They comprised $8.6 \%$ of the total population in 1904 , with the vast majority living in the Cape Colony. ${ }^{16}$

Although the whites in South Africa were descended from German, French, Dutch, and other European settlers, they fell generally into two cultural and linguistic groups: the British and Afrikaners (or Boers). Afrikaners descended from the first European colonists to the country. Johan Anthonisz (Jan) van Riebeeck founded the first Dutch settlement at the Cape of Good Hope on April 6th, 1652 at the instruction of the Dutch East India Company. ${ }^{17}$ Later colonists including German missionaries and other Europeans melded into what became

\footnotetext{
${ }^{14}$ Mohamed Adhikari, 2005. "Contending Approaches to Coloured Identity and the History of the Coloured People of South Africa". History Compass. 3, no. 1. doi: 10.1111/j.14780542.2005.00177.x. 1.

${ }^{15}$ Recent genetic studies suggest that most of the mitochondrial DNA comes from that of the Khoikhoi. See: Quintana-Murci, Lluis, C Harmant, H Quach, O Balanovsky, V Zaporozhchenko, C Bormans, van Helden PD, EG Hoal, and DM Behar. 2010. "Strong Maternal Khoisan Contribution to the South African Coloured Population: a Case of Gender-Biased Admixture". American Journal of Human Genetics. 86, no. 4: 611-620.

${ }^{16}$ Hancock, Smuts, 219.

17 Giliomee, The Afrikaners: Biography of a People, 1.
} 
known as the Boers ${ }^{18}$ and Cape Dutch. ${ }^{19}$ By the end of the eighteenth century the identity of the "Afrikaner" had taken prominence over that of being Dutch or German, and their language had developed into a dialect of Dutch now known as Afrikaans. ${ }^{20}$ Because of their perception of the "tyranny of British imperialism" and the British abolition of slavery, ${ }^{21}$ approximately 15,000 Boers along with an estimated 5,000 servants loaded up their wagons and traveled west into the interior of the country during the $1830 \mathrm{~s}$ and $1840 \mathrm{~s} .{ }^{22}$ This mass migration became known as "The Great Trek" and the Trekboers settled in sections of Natal, the Orange Free State, and the Transvaal. ${ }^{23}$

The legacy of British imperialism in South Africa is the subject of hundreds of monographs and engenders contentious debate among scholars, politicians, and laypeople. ${ }^{24}$ After seizing control of the Cape colony in 1806 after years of back-and-forth control with the Dutch, the British ruled the territory for the next 104 years. During that period, they abolished slavery, encouraged considerable immigration of British settlers, engaged in many frontier wars with various native

\footnotetext{
${ }^{18}$ Boer is Dutch for "farmer." They are also known as Afrikaners.

${ }^{19}$ Giliomee, The Afrikaners: Biography of a People, 10-13.

20 Giliomee, The Afrikaners: Biography of a People, 52-53.

${ }^{21}$ Britain abolished the slave trade in 1807 , but mitigated the impact of that act with various laws such as the "Hottentot Code" of 1809 which required Khoikhoi laborers to carry passes to move in public. White missionaries and an unsympathetic British public put pressure on the British parliament to pass Ordinance 50 in 1829 which removed the worst provisions of the 1809 law and made Khoikhoi free men. The Slavery Abolition Act was passed in 1833 which prohibited the purchase, sale and ownership of slaves throughout the British Empire.

22 Giliomee, The Afrikaners: Biography of a People, 161.

${ }^{23}$ For more on the Great Trek see Giliomee, The Afrikaners: Biography of a People, 161-192.

${ }^{24}$ A good starting point is Christopher C. Saunders, The Making of the South African Past: Major Historians on Race and Class. (Totowa, N.J.: Barnes \& Noble Books, 1988).
} 
groups, developed a communication and transportation infrastructure, and implemented a parliamentary legal system. At the turn of the twentieth century, they fought a devastating war against the Afrikaners for control of the interior of the county.

The final major demographic group representing $2.4 \%$ of the total population in 1904 was that of the Asiatic peoples, mainly from China and India. ${ }^{25}$ The first Chinese and Indians to arrive were convicts and slaves of the Dutch East India Company who arrived in the 1650 s-1700s. ${ }^{26}$ In the 1860 s the Natal government began importing Indian indentured servants in order to work on sugar plantations in the colony. ${ }^{27}$ Over 150,000 Indian migrants arrived between 1860 and 1911 , the vast majority as indentured servants on five to ten years contracts. ${ }^{28}$ Chinese immigration increased beginning in the 1870 s with the discovery of gold and diamonds. After the South African War (1899-1902) Chinese immigration increased dramatically, as the black populations were often

\footnotetext{
${ }^{25}$ Hancock, Smuts, 219.

${ }^{26}$ Nigel Worden, Slavery in Dutch South Africa. Cambridge [Cambridgeshire]: Cambridge University Press, 1985; and Yoon Park, "Living In Between: The Chinese in South Africa" The Online Journal of the Migration Policy Institute. January 4th, 2012, accessed January 9, 2016. http://www.migrationpolicy.org/article/living-between-chinese-south-africa.

${ }^{27}$ Plantation owners found it difficult to convince Africans to do the arduous work required to farm sugar, especially since they had no former knowledge of how to do so. See Leonard Monteath Thompson, A History of South Africa. (New Haven, CT: Yale University Press, 2001), 100.

${ }^{28}$ Gerald J. Pillay, "Community Service and Conversion: Christianity among Indian South Africans" in Elphick, Richard, and T. R. H. Davenport. Christianity in South Africa: A Political, Social, and Cultural History. (Berkeley, Calif: University of California Press, 1997), 286; T. R. H. Davenport, and Christopher C. Saunders. South Africa: A Modern History. (Hampshire, England: Macmillan Press, 2000), 120-121; and Thompson, A History of South Africa, 98-100.
} 
unwilling to work for the low wages paid by the mining companies and white laborers deemed the work too dangerous.

The latter half of the nineteenth century witnessed enormous changes in the social, economic, and political spheres of virtually all these South African societies. The catalyst for these transformations lay in the discovery of diamonds and gold in the 1870s and 1880s. The discovery of diamonds at Kimberley in 1867 and gold on the Witwatersrand in the 1880 s prompted revolutionary change internally, and made the county, as Leonard Thompson argued, "for the first time, a significant contributor to the world economy." ${ }^{29}$ Just as the Californian Gold Rush had attracted prospectors from every continent, so did the discovery of gold and diamonds in South Africa. ${ }^{30}$ Gold was especially critical: In the 1890 s it accounted for over fifty percent of South Africa's total exports, rising to over seventy percent by the end of the 1930s. ${ }^{31}$

The mineral revolution and subsequent rise of the capitalist mining industry affected every aspect of life, but it prompted a unique migrant labor system with the most far-reaching implications for the region. South African scholar Norman Levy writes: "Although the gold mines on the Rand were not unique in their employment of labour-intensive techniques, they were unique in

\footnotetext{
29 Thompson, A History of South Africa, 110.

${ }^{30}$ Clarence C. Clendenen, Robert O. Collins, and Peter Duignan. Americans in Africa, 18651900. (Stanford, CA: Hoover Institution on War, Revolution, and Peace, Stanford University, 1966), 87-88.

${ }^{31}$ C. H. Feinstein, An Economic History of South Africa: Conquest, Discrimination, and Development. (New York: Cambridge University Press, 2005), 108.
} 
responding to cost inflation by perfecting the recruitment and organization of the system of migrant labour, which was the singularly central feature of the labour structure on the Rand." 32 Initially, thousands of Africans left their rural homes for the cities to work in the mines, typically for the summer or a number of months at a time, using their income to purchase cattle or guns before returning home to their families ${ }^{33}$ Coloureds and Indians migrated to the cities to set up shops and take advantage of a rapidly developing wage economy. Mining required tremendous amounts of fixed, permanent laborers, and labor shortages were often a deep concern for the mine companies and the government. The government passed laws in order to restrict movement and the mining companies developed employment tactics such as long-term contracts in work compounds in order to ensure a readily available supply of workers. Racial segregation and discrimination were hallmarks of the mining industry, and the Transvaal government favored the whites in issues of dispute. ${ }^{34}$ In his summary of the socio-economic transformation, historian David M. Smith emphasizes that "not a single part of rural South Africa reached the turn of the [twentieth] century with a substantial body of people able to escape the pressures of incorporation

\footnotetext{
${ }^{32}$ Norman Levy, The Foundations of the South African Cheap Labour System. (London: Routledge \& Kegan Paul, 1982), 20.

${ }^{33}$ Africans placed more value on cattle and livestock than they did on cash, and as pastoralist people much of their culture was built around cattle raising. Many practiced a system of bridewealth called lobola which was used to regulate marriages and establish families. The Zulu, Swazi, Xhosa, and Ndebele in particular viewed cattle as the embodiment of wealth. See: Leroy Vail, The Creation of Tribalism in Southern Africa. (Berkeley: University of California Press, 1991), 8.

34 Thompson, A History of South Africa, 121.
} 
into a rapidly growing capitalist economy." ${ }^{35}$ These shifts in population due to the mining, industrial, and agricultural revolutions began a long process of urbanization, particularly among blacks that would continue throughout the twentieth century. ${ }^{36}$

Besides reordering the economy and demographics, the discovery of precious minerals and increasing immigration also exacerbated tensions between the British and the Boers, which culminated in the two Anglo-Boer Wars; the first $1880-1881$, with the second and more deadly war known as the South African War in 1899-1902. With the black majority of the population caught in the middle, the South African War ravaged the country. ${ }^{37}$ John G. Lake described

${ }^{35}$ David M. Smith, The Apartheid City and Beyond: Urbanization and Social Change in South Africa. (London: Routledge, 1992), 14.

${ }^{36}$ C.F. Swart, "Urbanization - Catalyst for Socio-Economic and Political Change" in D.J. Van Vuuren, et al, Change in South Africa. (Durban: Butterworths, 1983), 98.

${ }^{37}$ The British had been at odds with the Afrikaners since South Africa's colonial period which resulted in the Great Trek and the eventual first war in 1880-1881 between Afrikaners and British. In an 1833 act of Parliament, the British banned slavery throughout the British Empire. The Boers felt this was yet another example of British overreaching. Thus, many left in what is known in history as the "Great Trek" in order "to restore economic, cultural and political unity independent of British power." Most historians have recognized the Great Trek as one of the most important events in South African history, with some calling it the "supreme disaster" and others the "central event." The Vortrekkers formed the three states of Natal, Transvaal, and the Orange Free State. While slavery was not explicitly allowed in these areas, racial segregation was heavily enforced. Furthermore, the states were established in land that belonged to various Zulu tribes and conflict erupted over claims to these so-called "empty" spaces, the most famous of which was the Battle of Blood River. Several thousand Zulu were killed while the Boers only incurred minor casualty losses, and this battle was interpreted as a sign that God was on their side. The legacy of the Battle of Blood River and the Great Trek as a whole was to bolster Boer ethnic nationalism which is key in understanding how Boers saw themselves and their relation to blacks. See "The Great Trek" South African History Online, accessed Dec 10, 2010. http://www.sahistory.org.za/pages/governence-projects/great-trek/great-trek1.htm; Macmillian, quoted in Timothy J. Keegan, Colonial South Africa and the Origins of the Racial Order. (Charlottesville: University Press of Virginia, 1996), 2. 
the results of the British scorched-earth policy in a letter to The Upper Room in June 1909: "Everything that could be burned was burned and the cattle were killed, simply to cut off the food supply to the Boers in order to end the war. The result is this country is in a very hard plight financially, and will be for a good many years to come. It is like the South in America was at the close of the Civil War." ${ }^{38}$ This war between the British and the Boers was particularly defining, as Boers saw themselves as simply defending their land and farms from the British Empire who wanted the Boer's gold mines. The British, for their part, believed the war would be an easy victory. The Republican Afrikaners were frontier men and women who engaged in guerrilla tactics against the British, and despite being outnumbered 500,000 to 60,000 , the Boers managed to stave the British off for two and a half years. Yet in the end they suffered a humiliating defeat; their nation gone, their farms burned and salted, the women and children in concentration camps, and thousands dead. ${ }^{39}$

38 The Upper Room, June 1909. Republished in Curry R. Blake, John G. Lake's Writings From Africa, (USA: Xulon Press, 2005), 10.

39 Two particular elements of the war were critical in influencing both Boer nationalism and creating a new country with the foundations of segregation that would lead to apartheid in the future. The first element was the concentration camps. While atrocities were committed on both sides, in the face of surprising resistance by the Boers, the British chose to engage in a scorchedearth policy that destroyed the land and drove Boer women and children into British so-called "refugee camps." In actuality these were some of the first know use of concentration camps. Inside these camps Boer women and children often received too little food, water, or medication, and sanitation conditions were terrible. Word of the conditions of these camps marred Britain's image back home and throughout the Atlantic world, and the memory of the camps played a huge role in increasing nationalist attitudes amongst the Boers. Historian E. Van Hayningen has written extensively on the camps and contends that the "mythology of the concentration camps of the South African War had been firmly lodged in the historical consciousness of Afrikaners, establishing a paradigm of suffering that has altered remarkably little since." Finally, in the Peace Treaty of Vereeniging, the British failed to follow through with their promises to enfranchise black Africans during the war stating that "the question of granting the franchise to natives will not be decided until after the introduction of self-government." Thus the Great Trek, Battle at Blood River, and South African War all played crucial roles in defining what it meant to be Afrikaner. 
Besides devastating the country, the war also had profound consequences for the racial politics of the country. Africans believed that their livelihoods might improve after the war, since one of the accusations that the British had maintained against the Afrikaners was their poor treatment of natives and blacks. Yet the Treaty of Vereeniging that ended the conflict helped to ensure that the newly founded country would be ruled by a minority of whites for many years, and ensured the eventual racial conflicts of the 20th century in South Africa. ${ }^{40}$ Indeed, in the aftermath of the war, the new government passed a series of laws and acts designed expressly to monopolize power in the hands of the white minority. The ensuing Milner regime in most cases worsened the lots of blacks by reestablishing Afrikaner landowners, tightening pass laws for African workers, and siding with mining management at the expense of worker's rights. ${ }^{41}$

The religious landscape of South Africa in 1900 mirrored the conflicts and confusions of the nation's demography, politics, and economy. Robert Shell argues that within the Cape society, religious identity was composed of four tiers:

See: Parliamentary Papers, 1902, LXVIII Cd. 939. Online in Stanford University's Africana Collections "Concentration Camps, Parliamentary Papers, 1902, LXVIII", accessed Dec. 10 2010. http://www-sul.stanford.edu/depts/ssrg/africa/parlstat.html; E. Van Heyningen, 2008. "Costly Mythologies: The Concentration Camps of the South African War in Afrikaner Historiography". Journal of South African Studies. 34 (3): 495-513; and The Peace Treaty of Vereeniging, digitized online at http://www.sahistory.org.za/pages/governence-projects/angloboer-wars/vereeniging2.htm. Accessed December 10, 2010.

${ }^{40}$ For more on the political and social developments in early twentieth century South Africa, see: William Beinart, Twentieth-Century South Africa. (Oxford: Oxford University Press, 2001); William Beinart and Saul Dubow. Segregation and Apartheid in Twentieth-Century South Africa. (London: Routledge, 1995); John Whitson Cell, The Highest Stage of White Supremacy: The Origins of Segregation in South Africa and the American South. (Cambridge: Cambridge University Press, 1982); and Thompson, A History of South Africa.

41 Thompson, A History of South Africa, 144-146. 
"Christians, Muslims, pagan slaves, and unbaptized bastards." 42 The faith and practices of these "pagans" and "unbaptized bastards" exaggerates the confusion of the religious picture. While "traditional African religion" was itself a loose collection of rituals, practice, myth, and faith, the various ethnicities - from Khoikhoi to Zulu - had their own unique usages as well. Despite this complexity, however, certain common elements stand out. ${ }^{43}$

Despite the problems associated with synthesizing such a large group of diverse groups, scholars have identified a few commonalities amongst the diverse traditional religious beliefs of Southern Africa. African traditional religion thought tended to center around conceptions of animism and mysticism. Animistic societies that believed that the natural world was imbued with spiritual essence. While most of the Bantu-speaking tribes conceptualized a supreme God, they were hardly monotheistic, for they did not emphasize this element and several groups believed in many deities. ${ }^{44}$ The in a divine being that was both providential and causal in their lives. Some oral traditions portray God in anthropomorphic terms, but He is mostly described in abstract terms as one who

\footnotetext{
${ }^{42}$ Robert Carl-Heinz Shell, Children of Bondage: A Social History of the Slave Society at the Cape of Good Hope, 1652 - 1838. (Hanover: University Press of New England, 1994), 364.

${ }^{43}$ By "Traditional African Religion" I mean the original religion of African peoples. This term had engendered much debate amongst scholars of religion and there is still a wide debate over whether there existed one religion of African people, or many religions with one religious philosophy, or yet still that there exists no one clear African religion.

${ }^{44}$ Bantu-speaking peoples is a general term that refers to all Bantu-speaking language groups. There are estimated to be 300-600 groups that range from central to southern Africa. For example, Zulu mythology hold to many deities, with uNkulunkulu being the supreme god and creator of everything. Likewise the Xhosa believed in a supreme god named Tixo. See Edwin W. Smith, "The Idea of God Among South African Tribes," in Edwin W. Smith (Ed.) African Ideas of God. (London: Edinburgh House Press, 1950), 78-134.
} 
gives life, fertility, and death. ${ }^{45}$ Thus unlike most Western religion, there was no line drawn between the supernatural and the physical realms. As a result, the concept of chance was foreign to the world-view of South African Bantu groups, as everything had a cause. ${ }^{46}$

Other common threads of thought included the veneration of ancestors, as South African social anthropologist Eileen Krige argued, "The real, vital religion of the Zulus is their ancestor worship." 47 The practice of magic was yet another common trait. ${ }^{48}$ Magic belief systems were based on a sort of natural logic and association of ideas. ${ }^{49}$ Most Bantu societies shared similar ideas about witches, believing them to be people, typically women, were able to use supernatural powers to harm others. ${ }^{50}$

After the traditional religious faiths of the Africans, the Dutch Reformed Church constitutes the second critical element in the fragmented religious landscape of the country. Since the arrival of the Dutch in 1652, the Dutch Reformed Church, known in Afrikaans and Dutch as the Nederduitse Gereformeerde Kerk (NGK), was the establishment church of the Cape colony

\footnotetext{
45 Yves Bonnefoy and Wendy Doniger. Mythologies. (Chicago: University of Chicago Press, 1991), 62.

${ }^{46}$ W. D. Hammond-Tooke and Isaac Schapera. The Bantu-Speaking Peoples of Southern Africa. (London: Routledge \& K. Paul, 1974), 336.

${ }^{47}$ Eileen Jensen Krige, The Social System of the Zulus, 1936. As quoted in Sundkler, Bengt. Bantu Prophets in South Africa. (London: Published for the International African Institute by the Oxford University Press, 1961), 21.

${ }^{48}$ Bengt Sundkler, Bantu Prophets in South Africa, 19-24.

${ }^{49}$ Hammond-Tooke and Schapera, The Bantu-Speaking Peoples of Southern Africa, 340.

$50 \mathrm{lbid}, 337$.
} 
and had essentially monopolized the public expression of Christianity, particularly among the Afrikaners. ${ }^{51}$ The NGK congregations broke with Holland in 1824 out of a desire to control their own affairs. Dutch reformed theology was descended from Calvinist thought and thus included covenant theology and the doctrine of the sovereignty of God. ${ }^{52}$

The religious landscape of Calvinism and traditional African religion became still more confused at the beginning of the nineteenth century as waves of Protestant missionaries flooded the territory. Over the course of the nineteenth century, Southern Africa became the site of one of the most intense, diverse, and expansive mission fields on earth. ${ }^{53}$ Much of this activity was driven by the

\footnotetext{
${ }^{51}$ Richard Elphick, "Christianity in South African History" in Elphick and Davenport, Eds., Christianity in South Africa, 2. Catholicism was limited since the Dutch East India Company had prohibited the practice at the Cape. See W. E. Brown, The Catholic Church in South Africa, From its Origin to the Present Day (London: Burn \& Oats, 1960).

52 Johnathan N. Gerstner, "A Christian Monopoly: The Reformed Church and Colonial Society Under Dutch Rule” in Elphick and Davenport, Eds., Christianity in South Africa, 17-18.

${ }^{53}$ See: James R. Cochrane, Servants of Power: The Role of English-Speaking Churches in South Africa, 1903-1930 : Toward a Critical Theology Via an Historical Analysis of the Anglican and Methodist Churches. (Johannesburg: Ravan Press, 1987); Kenneth C. Barnes, 2002. "'On the Shore Beyond the Sea": Black Missionaries from Arkansas in Africa During the 1890s". The Arkansas Historical Quarterly. 61, no. 4: 329-356; James T. Campbell, Songs of Zion: the African Methodist Episcopal Church in the United States and South Africa. (New York: Oxford University Press, 1995); John W. De Gruchy, The Church Struggle in South Africa. (Grand Rapids: W.B. Eerdmans Pub. Co.), 1979; John W. De Gruchy, The London Missionary Society in Southern Africa, 1799-1999. (Athens, Ohio: Ohio University Press 2000); Elizabeth Elbourne, Blood Ground: Colonialism, Missions, and the Contest for Christianity in the Cape Colony and Britain, 1799-1852. (Montreal: McGill-Queen's University Press, 2002); Patrick Harries, Butterflies and Barbarians: Swiss missionaries and systems of knowledge in South-East Africa. (Oxford: Currey, 2007); D. Killingray, "The Black Atlantic Missionary Movement and Africa, 1780s - 1920s" Journal of Religion in Africa, 1 January 2003, vol. 33, no. 1, pp. 3-31 (29); Bhekizizwe Peterson, Monarchs, Missionaries \& African Intellectuals: African Theater and the Unmaking of Colonial Marginality. (Trenton, NJ: Africa World Press Inc., 2000); Jane M. Sales, The Planting of the Churches in South Africa. (Grand Rapids, Mich: Eerdmans, 1971); Walter L. Williams, Black Americans and the Evangelization of Africa, 1877-1900. (Madison, WI: University of Wisconsin Press, 1982); and Johannes Du Plessis, A History of Christian Missions in South Africa. (Cape Town: C. Struik, 1965).
} 
discovery of gold and diamond in the interior of the country, which made Kimberley and Johannesburg the gravitational points for a vast migration of African, Chinese, and Indian laborers. ${ }^{54}$ Even more so than the US, the religious landscape of Southern Africa resembled a marketplace of competing Christian brands of faith. Church leaders at the time frequently commented on this feature of the country, as have later South African historians like Peter Hinchliff, who described this element as "the great curse of nineteenth century missionary expansion." 55

Beginning in the late eighteenth century, Protestant missionaries challenged the NGK's turf. The movement began in 1792 with the reestablishment of the German-speaking Moravians, but took hold when the London Missionary Society (LMS) began operations in Southern Africa in 1799. 56 The British gained control of the colony in 1806, and this ushered in a virtual tidal wave of Protestant missionaries from various regions and denominational backgrounds. This set up conflict between the DRC churches that mainly ministered to white settlers, and the new "mission" churches who were more interested in "converting the heathen." ${ }^{57}$ The role of European missionaries in

\footnotetext{
${ }^{54}$ Bengt Sundkler, Bantu Prophets in South Africa. (London: Oxford University Press, 1961), 27.

${ }^{55}$ Peter Bingham Hinchliff, The Church in South Africa. (London: S.P.C.K. for the Church Historical Society, 1968), 72.

56 The Moravians had first established a mission station in 1737, but had to close down in 1743 after dealing with pressure from white colonials and other local church authorities. It reopened in 1792 . See Rodney Davenport and Christopher Saunders, South Africa: A Modern History. (Basingstoke, UK: Palgrave Macmillan, 2000), 186.

57 John W. De Gruchy, The Church Struggle in South Africa (Minneapolis: Fortress Press, 2005), 2; Elbourne, Blood Ground: Colonialism, Missions, and the Contest for Christianity in the Cape
} 
buttressing colonialism in South Africa is a subject of much debate. ${ }^{58}$ By the end of the nineteenth century, southern Africa had become one of the world's most

crowded "mission fields." 59

Colony and Britain, 1799-1852, 115.

${ }^{58}$ Early works dealing with missions in South Africa have tended to argue that missionaries were agents of colonialism. One of the first to make this case for "missionary imperialism" in South Africa was Anthony J. Dachs. He analyzed the role of missionaries to the Tswana peoples in South Africa and contended that missionary attempts to alter cultural behaviors like polygamy, initiation ceremonies, and religious practices was met with resistance by the Tswana and he concludes that "the power to which the missionaries looked was the secular force of British imperialism." Julian Cobbing takes this position even further, by implicating missionaries in the slave trade, asserting that in the battle of Dithakong, missionaries "were the instigators and organizers both of the raid and the disposal of the prisoners." In their foundational text on the Tswana people of South Africa, the Comaroffs build off Dachs's conclusions and use a Gramcian perspective to support their argument that wittingly or unwittingly, European missionaries were "the human vehicles of a hegemonic worldview" which would eventually "remake" Tswana consciousness and the hegemonic forces of cultural colonialism paved the way for political colonialism. However the Comaroffs stop short of denying Africans agency in their adaptation of Christianity for their own purposes. Jean Comaroff states in her article "Missionaries and Mechanical Clocks" that while "the nonconformist mission in southern Africa helped sow the state of colonialism on which the colonial state was founded" it nonetheless provided "a language for contesting the new modes of domination it had itself helped create." The move towards a more multidimensional and complex view of the relationship between missions and Africans in the colonial period can be seen in the works of scholars like Richard Grey, who argues that "above all, the argument that Christianity in sub-Saharan Africa has been merely part of the ideological superstructure of Western capitalism ignores the fundamental contributions of African Christians and of African cosmologies." Clifton Crais also argues that the syncretic "integration of cultural symbols and knowledge could be both hegemonic and potentially revolutionary: religious belief could legitimate the inequalities of the present as well as provide a radical critique and understanding of the alienation which accompanied conquest and dispossession." Thus while missionaries may have desired to bring "civilization" to South African peoples, education and Christianity were ironically tools in the hands of South Africans to resist European cultural hegemony. See: Anthony J. Dachs, "Missionary Imperialism - the Case of Bechuanaland". The Journal of African History 13, no. 4 (1972): 647-658; Julian Cobbing. "The Mfecane As Alibi: Thoughts on Dithakong and Mbolompo". The Journal of African History. 29, no. 3 (1988); Jean and John L. Comaroff, Of Revelation and Revolution: The Dialectics of Modernity on a South African Frontier V.I\&II. (Chicago, IL: University of Chicago Press, 1991); Jean Comaroff. "Missionaries and Mechanical Clocks: An Essay on Religion and History in South Africa". The Journal of Religion 71, no. 1 (1991): 1-17; Richard Gray, Black Christians and White Missionaries. (New Haven: Yale University Press, 1990); and Clifton C. Crais, White Supremacy and Black Resistance in Pre-Industrial South Africa: The Making of the Colonial Order in the Eastern Cape, 1770-1865. (Cambridge, England: Cambridge University Press, 1992).

${ }^{59}$ Elbourne, Blood Ground, 11. 
In the midst of all this, the religious landscape of the territories was undergoing waves of revivalism. Beginning in 1850 s, and increasing in intensity toward the end of the nineteenth century, there was a worldwide phenomenon of inter-denominational Protestant revivalism. ${ }^{60} 1858$ saw the advent of a worldwide revival that had a particularly intense effect in the United States, Britain, and South Africa. ${ }^{61}$ Revivalism emphasized a personal and emotional encounter with God through the Holy Spirit that resulted in repentance and salvation. Occasionally these religious revivals corresponded with an emphasis on social and political reforms. The mid-1800s witnessed a number of revivals that often, but not always, had ties with the Holiness movement in the United States and the Keswick movement in Great Britain. ${ }^{62}$ One of the most influential Holiness

\footnotetext{
${ }^{60}$ For more on the rise of international Pentecostalism, see John Thomas Nichols, Pentecostalism. (New York: Harper and Row, 1966); Walter J. Hollenweger, The Pentecostals: The Charismatic Movement in the Church. (Minneapolis: Augsburg, 1972); Nils Block-Hoell, The Pentecostal Movement: Its Origin, Development, and Distinctive Character. (Oslo: Universitetsforlaget; London: Allen and Unwin; and New York: Humanities Press, 1964).

${ }^{61}$ For more on this period of revivalism see: J. Edwin Orr and Richard Owen Roberts. The Event of the Century: The 1857-1858 Awakening. (Wheaton, IL: International Awakening Press, 1989); Kathryn Teresa Long, The Revival of 1857-58: Interpreting an American Religious Awakening. (New York: Oxford University Press, 1998); Sandra L. King, The 1857 Hamilton Ontario Revival: An Exploration of the Origins of the Layman's Revival and the Second Great Awakening. (Eugene, OR: Pickwick Publications. 2015); and John Corrigan, Business of the Heart: Religion and Emotion in the Nineteenth Century. (Berkeley, CA: University of California Press, 2002).
}

62 In 1858 the American pastor William Edwin Boardman (1810-1886) published his international bestseller The Higher Christian Life, which sparked the Keswick movement in Great Britain. The Keswick movement echoed the theology and practice of the American Holiness Movement by advocating a "second conversion" in the Christian's life, but stopped just short of embracing outright perfectionism. Instead they contended that the Holy Spirit was capable of fighting off worldly temptations and endowing believers with power to overcome spiritual battles in order to live a life that was pleasing to God on earth. Keswick theology is essentially one stream of "second blessing" theology among many. They differ from the later Pentecostals in that they did not view tongues as evidence of spiritual baptism. Keswick teachings emphasized that the Holy Spirit was evidenced in the life and heart of the believer, not in any one particular act of spirituality. The British adherents formed their first Keswick Convention in 1875. By 1860 revival hit the Dutch Reformed Church, South Africa's oldest institutionalized church, established by Jan van Riebeeck in 1652. It was followed by similar waves of revival in 1874 and 1884. See: William 
ministers of this era was Andrew Murray Jr. (1828-1917), the son of the famous Dutch Reformed minister Andrew Murray Sr. (1794-1866). Beginning in 1858, brothers Andrew and John Murray oversaw dozens of revivals in South Africa which helped to revitalize and reform Dutch Calvinism in the Dutch Reformed Church. ${ }^{63}$ Likewise, revivals broke out in Sweden in 1905, and subsequently spread to Germany, France and other areas in Europe. One of the most wellknown revivals of this period was the 1904-1905 Welsh revival, in which several thousand adopted the Christian faith. Its influence sparked subsequent revivals in India, Korea, and China, and is also credited with influencing revivals in the United States. An Indian woman named Pandita Ramabai led the Mukti revival movement from her Mukti mission between 1905 and $1907 .{ }^{64}$ Thus at the turn of the century, South Africa was part of a worldwide phenomenon of revivalism.

Both a cause and effect of conflicting influences, a final phenomenon was shaping the country's religious life: Africans were organizing their own churches and effectively institutionalizing their own practices apart from all of these other influences. Towards the end of the nineteenth century, black South Africans

\footnotetext{
Edwin Boardman, The Higher Christian Life, (Chicago, IL: W.M. Tomlinson, 1858), accessed December $18^{\text {th }} 2015$.

http://www.archive.org/stream/higherchristianlife00boarrich\#page/n5/mode/2up.

${ }^{63}$ Andrew Murray Jr. was educated in Scotland but returned to his native South Africa and became one of the chief figures of the 1860 South African Revival. An avid writer, he published over 240 books during his lifetime, and became heavily involved in bringing the Keswick movement to South Africa. Murray was part of a growing trans-Atlantic network of Protestants who were embracing a "second blessing" theology and advocating that the power of the Holy Spirit could be manifest in a believer's life. John W. de Gruchy, The Church Struggle in South Africa (25th Anniversary Edition), (Minneapolis, MN: Fortress Press, 2004), 9.

${ }^{64}$ Allan Anderson, To the Ends of the Earth: Pentecostalism and the Transformation of World Christianity, (New York, NY: Oxford University Press, 2013), 25.
} 
leaving white churches to found "African" initiated churches of their own. ${ }^{65}$ This African Independent Church movement was a form of protest against the increasing disenfranchisement of blacks in the country, particularly in the religious sphere. ${ }^{66} \mathrm{~A}$ white missionary at the time explained that the uniting factor was the "religious social, and political aspirations" of the movement represented "...the reply of the Native to the unfriendly, almost hostile attitude of the colonist." 67 This separatist movement had lasting implications for black and white South Africans. Some, like the Ethiopian movement, were more overtly politicized than others, but the overarching concern for many black South Africans was tension over the cultural essence of Christianity. Many desired the faith, community, and liberation of the religion without the European trappings of colonialism that came with it. ${ }^{68}$

65 "AIC" stands for African Independent Church or African Initiated Church. The origins of the AIC movement can be traced at least back to Nehimiah Tile's Thembu church, established in 1884 . Dissafected with the white control of the Anglican Church, Joseph Mathunye Kanyane Napo seceded from the Anglican Church in 1888 to form the African Church. Mangena Mokone's Ethiopian church was established in 1892 after he and other blacks were excluded from a meeting of white Wesleyans in Pretoria. These two branches of AICs together formed the Ethiopian church movement, although some scholars like Bengt Sundkler have broadened the definition to include all AIC denominations that broke away from Wester-Protestant churches to found black-led congregations. By 1898 the AIC members numbered 10,000 among 73 congregations. See: Davenport and Saunders, South Africa: A Modern History, 242-244.; Sundkler, Bantu Prophets in South Africa, 38-50.; Martin Elgar West, Bishops and Prophets in a Black City: African Independent Churches in Soweto, Johannesburg. (Cape Town: D. Phillip, 1975).

${ }^{66}$ Bengt Sungtler provided a typology of AICs in his 1961 work. He described them as including two major categories - Ethiopian and Zionist - as well as some messianic churches.

${ }^{67}$ Reverend Frederick B. Bridgman, American Board Mission, on July 20th, 1904, in Report of the Proceedings of the First General Missionary Conference Held at Johannesburg, July 14-20, 1904. (Johannesburg: The Argus Printing and Publishing Co. Limited, 1905), 174.

${ }^{68}$ Many Africans did not feel that the nineteenth century missionaries offered them Christianity on their own free terms. While there were a few examples of missionaries like James Read and Johannes van der Kemp who became completely absorbed in their work amongst the people, many mission societies required accommodation to European culture as a sort of rite of passage 
It was amid this confused scene of cultural change, economic disorientation, ethnic diversity, and religious conflict that the first Pentecostal witnesses appeared in the country in May of 1908. The origin of the missionary impulse to the country illuminates much of the spirit of the larger Pentecostal movement. The majority of the all-white American group had formed in Indianapolis, Indiana during a February missionary convention. ${ }^{69}$ They were John Graham Lake, Jennie Lake, and their seven children; Thomas and Charlotte Hezmalhalch, Jacob O. And Lily Lehman, and Ida Florence Sackett. ${ }^{70}$ Agents told them of South Africa and of the need for missionaries. ${ }^{71}$ Feeling called to take the witness to South Africa, the group made plans to leave in April. None of

for conversion. These often included "minor" accommodations such as changes in dress, or speech, but more frequently involved the convert to dispense with major elements of his or her traditional culture. For example, circumcision rituals, polygamy, and bride price were frequent points of contention between missionaries and tribal chiefs. Such rituals played important political and economic roles within many South African communities, and made missionary efforts difficult. Most significantly, missionaries often approached Africans with a highly Westernized gospel that was simply too foreign for comprehension. For all these reasons, many black South African Christians chose to leave mission-originated churches towards the end of the nineteenth century in order to found independent "African" Christian churches, which would allow them to embrace a form of Christianity that was African in worldview, politics, and culture. See: For biographies on John Philip and Johannes van der Kemp, see Ido H. Enklaar, Life and Work of Dr J. Th. Van der Kemp 1747-1811. (Cape Town: A. A. Balkema, 1988); and Andrew Ross, John Philip (17751851): Missions, Race and Politics in South Africa. (Aberdeen, UK: Aberdeen University Press, 1986); Comaroff and Comaroff, Of Revelation and Revolution, 131-33, 138-140, 245; David Chidester, Savage Systems: Colonialism and Comparative Religion in Southern Africa. (Charlottesville: University Press of Virginia. 1996), 197-98; and Hildegarde H. Fast, "'In at One Ear and out at the Other': African Response to the Wesleyan Message in Xhosaland, 1825-1835." Journal of Religion in Africa 23 (1993). 147-174.

69 "Indiana Missionary Convention," The Apostolic Faith, January 1908, 2.

70 The Lakes, Hezmalhalchs, and Lehmans had ties to the Azusa mission where they had visited the revival. Ida Sackett was paralyzed below the waist. Hezmalhalch and Lake had disagreed over whether to allow Sackett to join the group due to her disability, but in the end they allowed her to accompany them. Her disability did not prevent her from working as an evangelist in South Africa. Although she believed that she would eventually be healed by God, she never was and eventually returned to the United States. Lake's sister Irene also accompanied the group. Burton, When God Makes a Pastor, 30, 35.

71 The Pentecost, Aug 1908, 6. 
them had the required fares for the trip, but they believed that since they were called, God would provide. ${ }^{72}$ Lake and his family prepared to leave so quickly that he had his brother settle the rest of his affairs. ${ }^{73}$ Formerly a wealthy business owner and real estate investor, John G. Lake claimed to have received the Holy Ghost Baptism in 1907, after which he quit his high-paying job and began his new career as a healing evangelist. ${ }^{74}$ In his diary, Lake explained: "When we say all to Jesus it means much my home, business, position among men, friends, family, even my dear wife could not at this time understand. God said go and preach." 75 The Hezmalhalchs likewise sold their land in California to afford the move. ${ }^{76}$ Louie Schneiderman and his wife Lillie also traveled with the group, but remained in London instead of immediately continuing on to Johannesburg. ${ }^{77}$ They totaled seventeen in all.

Although the impulse was driven by the belief in the gift of foreign tongues, none but the Lehmans had any understanding of the peoples to which they planned to witness. The Lehmans were the only members of the group who had actually formerly lived in South Africa, serving as missionaries to miners in the

72 The Pentecost, Aug 1908, 2.

${ }^{73}$ Burton, When God Makes a Pastor, 31.

${ }^{74}$ Isak Burger and Marius Nel, The Fire Falls in Africa: A History of the Apostolic Faith Mission of South Africa, 34; John G. Lake and Kenneth Copeland Ministries, John G. Lake: His Life, His Sermons, His Boldness of Faith. (Ft. Worth, TX: Kenneth Copeland Publications, 1994), xx-xxii.

75 Dairy of John Lake, October 1907, AFM Archives. 7.

${ }^{76}$ Burton, When God Makes a Pastor, 1934. 31.

77 The Schneidermans were converted Jews, and proselytized to other Jews in London for several months before continuing on to Johannesburg. 
Transvaal from 1901 to $1906 .{ }^{78}$ They returned to California in 1906 and visited the Azusa Street Revival upon their return and claimed that they received their spirit baptism there. ${ }^{79}$ By May 1907 they had moved to Indianapolis, where they met Thomas Hezmalhalch. ${ }^{80}$ Jacob at least was fluent in Zulu, which would prove useful to the group as they established the Apostolic Faith Mission. ${ }^{81}$

Arriving in Cape Town on May 14, the witnesses initially faced a range of difficulties. ${ }^{82}$ Sick, poor, and with few connections in Cape Town, the group struggled to survive. They held Azusa-inspired home church services for a few days while waiting for Lake's sister to recover from tuberculosis. ${ }^{83}$ The missionaries expressed dismay at the difficult living conditions including high rent for shabby housing ${ }^{84}$ Lake believed that they were called to minister along the Witwatersrand, and the Lehman's former experience in the area made it a practical place to start, so they left on a week-long journey to the Northwest. They first traveled to Pretoria, but after finding "no open door," they relocated to Johannesburg, arriving on May 23rd. ${ }^{85}$ The group's fortune changed there, as

\footnotetext{
${ }^{78}$ The Pentecost, August 1908, 2.

79 "Pentecostal Power in Indiana," The Apostolic Faith, February-March, 1907, 3.

80 Robeck, Cecil M. The Azusa Street Mission and Revival: The Birth of the Global Pentecostal Movement. (Nashville: Nelson Reference \& Electronic, 2006), 276.

81 Burton, When God Makes a Pastor, 31.

82 "The Forerunner of God's Latter Rain," August 1908. Johannesburg, South Africa. Reprinted in John G. Lake and Roberts Liardon. John G. Lake: The Complete Collection of His Life Teachings. (Tulsa, OK: Albury Pub, 1999), 44-48.

83 Liardon, John G. Lake: The Complete Collection of His Life Teachings. "The Wonderful Power of the Christian Life" a sermon delivered January 12th, 1922. 413.

${ }^{84}$ Letter from John G. Lake to J. Roswell Flower, published in The Pentecost, August, 1908. 6.

85 Comforter-Trooster, May 1948, 3.
} 
they found a Mr. And Mrs. Goodenough waiting at the train station, whom the group had met previously on the ship to South Africa. ${ }^{86}$ Mrs. Goodenough claimed that she had received a command by the Holy Spirit to meet them at the station, and invited them to her house and allowed them to live rent free in her "real missionary style" cottage ${ }^{87}$ While this proved a fortunate turn of events for the group, the Goodenoughs provided a critical platform to the group by inviting them to their Mission Hall, which just so happened to be a native church in Doornfontein in Johannesburg. ${ }^{88}$

Like Los Angeles, Johannesburg was a major metropolitan city that had seen explosive growth for the past few decades due to rapid immigration. Founded in 1886 after the discovery of gold on the Witwatersrand, Johannesburg had since experienced unprecedented growth. By the turn of the century, Johannesburg was home to 75,000 white residents and over 100,000 Africans. ${ }^{89}$ The booming mining industry attracted migrants from all over sub-equatorial Africa as well as Chinese and Indian laborers. The resulting cosmopolitan city was a hotbed of social and political unrest, as well as a center for literacy. In his work on migrant laborers in South Africa, Patrick Harries explains how literacy affected the miners:

Literacy allowed the worker to fit more easily into the expanded and complex society on the Witwatersrand, and it provided him with a new sense of power. The ability to read enabled him to comprehend the printed

\footnotetext{
${ }^{86}$ Comforter-Trooster, May 1948, 3.

87 The Pentecost, August 1908, 7.

88 Comforter-Trooster, May 1948, 3.

${ }^{89}$ Leonard Thompson, A History of South Africa, 120.
} 
words that made up his work ticket, the various passes controlling his movements, and the sign-posted instructions that regulated his life... Blacks who acquired a basic literacy and a rudimentary knowledge of arithmetic could occupy leadership positions in the local church and find relatively well-paid jobs as clerks, translators or letter-writers. An ability to read in the vernacular, and particularly in English, gave the miner access to worlds that were both spiritual and secular, while a familiarity with the symbols and codes of whites allowed him a certain upward mobility. ${ }^{90}$

Migrancy, urbanization, and growing literacy made the city an ideal

location for mission work. Migrant workers would often work at the mines for months at a time before returning home to their families in rural locations. This left them more susceptible in the eyes of missionaries to conversion. ${ }^{91}$ The concentration of workers in the city, combined with their dispersion to homes in the rural areas also made mission work in the city highly efficient. H. Kenneth Bedwell, a missionary in the International Holiness Association, described the potential value of the mining camps:

It does not take a vivid imagination to realize what tremendous strategic value the Rand offers for red hot evangelism. Here is an unprecedented opportunity of reaching the teeming thousands of natives who represent many tribes and practically the whole of South Africa. They represent kraals in the remote interior where the missionary can never hope to go. It must be remembered that Africa is a land of immense distances and scattered population. To reach the natives in their kraals means much traveling, and even then thousands are unreached. The Transvaal alone measures something like four hundred miles from north to south and more than six hundred miles from east to west... The Kruger National Park, which is reserved for wild animals in the Eastern Transvaal, is as large as the whole of Wales!92

\footnotetext{
90 Patrick Harries, Work, Culture, and Identity: Migrant Laborers in Mozambique and South Africa, C.1860-1910. (Portsmouth, NH: Heinemann, 1994), 215.

${ }^{91}$ Mastin Prinsloo, "Literacy in South Africa" pg. 5, accessed February $14^{\text {th }}, 2016$. http://www.education.uct.ac.za/sites/default/files/image_tool/images/104/99literacyinsouthafrica.p df.

$92 \mathrm{H}$. Kenneth Bedwell, Black Gold. The Story of the International Holiness Mission in South Africa. 1908-1936. (Cape Times: Cape Town, 1938), 27.
} 
Johannesburg proved to be yet another spiritual Jerusalem for the

Pentecostals. Lake claimed "My heart was drawn out toward the native work very intensely" and so they rented the "native tabernacle," which was owned by the Congregational American Mission..$^{93}$ On May 25th, 1908 the group held their first official service in the rented hall in Doornfontein. The first service was comprised mostly of black Africans - mostly Zulus - from neighboring Zionist churches. ${ }^{94}$ Lake preached through an interpreter who he described as "a woman who had lived among the Zulus for 30 years and was a progioient [sic] interpreter and an experienced missionary." ${ }^{95}$ Lake described the first meeting:

As the meeting progressed, a spiritual condition developed almost similar the dread silence, the deep stillness, that permeates the atmosphere preceding a cyclone. This condition in the Spirit climaxed in the native audience suddenly, as by a single impulse, bursting into prayer. Everyone prayed; saints and sinners alike; but no one came to the alter [sic]. No invitation was given. God had come in overwhelming conviction for sin, and we were not impressed that it was the mind of God to begin to reap until God, Himself, thrust in the sickle. We feel to say, out of life's experience as a Holy Ghost preacher, that we believe great damage is done by not waiting for a real ripeness of the work of the Holy Ghost in the soul of an audience... At the close of the meeting, my interpreter said: 'In all my missionary experience I never before have seen such a spirit of prayer on a native audience. But, dear brother, why did you not invite the sinful to come to the alter? [sic] There would have been numerous conversions.' I replied: 'I am waiting for God to give His own alter call by the Holy Ghost. ${ }^{\prime 96}$

\footnotetext{
${ }^{93}$ The Pentecost, August 1908, 7.

94 Isak Burger, Apostolic Faith Mission of South Africa 1908-2008. (Centurion: Apostolic Faith Mission of South Africa, 2008), 23.

95 "1st Doornfontein Sermon by Rev. John Lake" Typed document. AFM Archives.

96 "1st Doornfontein Sermon by Rev. John Lake" Typed document. AFM Archives.
} 
The revival instantly attracted a great deal of attention from the local public and religious leaders. Scoffers often attended to mock the participants and the missionaries, but were overshadowed by the participants. The meetings were by all accounts loud and interracial. In his 1934 book, William Frederick Padwick Burton (1886-1971) ${ }^{97}$ said of the Johannesburg revival:

The racial spirit is very strong in Johannesburg, and the white population, as a rule would scorn to sit in the same place of worship as the natives. Now however, there was a great wave of conviction, and hunger after God, so that in the little Doornfontein Chapel, all shades of colour and all degrees of the social scale mingled freely in their hunger after God. ${ }^{98}$

Confusion and disorder matched the enthusiasm. Thus one participant wrote, "At times pandemonium reigned, and while the people were being saved and blessed in front of the hall, godless opposers were shrieking and jeering at the back." 99 The sounds of shrieking, screams, singing, prayers, laughter, cries, dancing, jumping, and yelling together composed a typical revival meeting soundscape. It was an experience that drew in people by the hundreds every week. Participants took their "testimony" of having been baptized in the Holy Ghost back to their local churches, furthering news of the revival. ${ }^{100}$ In a letter to

\footnotetext{
${ }^{97}$ William Frederick Padwick Burton was a very influential figure in the spread of Pentecostalism to the Belgium Congo. He helped establish the Congo Evangelistic Mission in Mwanza 1915. He also is renowned for his scientific work on the Southeast Belgium Congo. See David Maxwell, "From Iconoclasm to Preservation: W.F.P. Burton, Missionary Ethnography, and Belgium Colonial Science" in Patrick Harries and David Maxwell, The Spiritual in the Secular: Missionaries and Knowledge About Africa. (Grand Rapids, Mich: W.B. Eerdmans Pub. Co, 2012).

${ }^{98}$ Burton, When God Makes a Pastor, 1934, 32.

${ }^{99}$ Burton, When God Makes a Pastor, 1934, 39.

100 Burton, When God Makes a Pastor, 1934, 40.
} 
J. Roswell Flower, editor of The Pentecost, Lake described an August meeting, saying:

The house was filled with natives, some with clothes on, one or two dressed in green table-cloths with a flashy-colored border, some with loincloths on, half of them barefooted, many with painted legs, etc., as is customary here. As the service proceeded the spirit of God fell upon the house in prayer. The natives recognized it just as quickly as we did, and without suggestion fell on their knees to pray as all natives here do, being exceedingly devout. They didn't wait for one another to pray. Out of the five hundred present, two hundred and fifty broke out in prayer aloud at one time. The missionaries who are with us, as observers, of the stately churchy order, were amazed and astounded because we did not stop the noise. ${ }^{101}$

Lake's contrast between the Holy Ghost-baptized natives and the aloof white missionaries points to the unfamiliarity of such emotional revivals. During these services, the Pentecostals preached a message that emphasized Baptism of the Holy Spirit, divine healing, and speaking in tongues. The meetings often lasted long into the night and early morning hours. "From the very start it was as though a spiritual cyclone had struck Doornfontein," wrote Burton in his description of the revival. ${ }^{102}$

As with Azusa, the sensational and controversial nature of the revival attracted people from all quarters of the city. News of the revival spread quickly throughout the city and "the place was speedily crowded with Europeans." ${ }^{103}$ The revival attracted many from other denominations as well. The revival at the rented hall in Doornfontein was so overcrowded that the neighboring Christian

\footnotetext{
101 The Pentecost, August 1908, 7.

102 Burton, When God Makes a Pastor, 1934, 32.

103 Comforter-Trooster, May 1948, 7.
} 
Catholic Apostolic Church in Zion (CCAC) invited the group to their larger Tabernacle at 39 Van Beek Street. ${ }^{104}$ An AFM pastor explained, "from the very first, so many of the Zion people attended [the native chapel in Doornfontein] these meetings that soon the Tabernacle doors were opened to these brethren, and then the fire began to fall mightily." 105 The Zion Tabernacle was expansive holding over 600 people - and the meetings were well attended. ${ }^{106}$ The congregants fully accepted the Pentecostal teaching of speaking in tongues and converted to the movement. ${ }^{107}$ While the movement began in a predominantly black chapel in Doornfontein, the CCAC tabernacle is viewed as the first organized Pentecostal assembly in South Africa. ${ }^{108}$ Soon, "people came from the Free State, Natal and the Cape to experience for themselves the power of God" wrote Cathy Crompton, a daughter of one of the participants. ${ }^{109}$ The Doornfontein revival had become the Azusa of South Africa. ${ }^{110}$

\footnotetext{
104 Comforter-Trooster, May 1948, 7.

105 P.L. Le Roux, "The Central Tabernacle," The Comforter, October 1913, 2.

${ }^{106}$ Burton, When God Makes a Pastor, 38.

${ }^{107}$ Bengt Sundkler, Zulu Zion and Some Swazi Zionists. (London: Oxford University Press, 1976), 52. AFM Leader P. L. Le Roux wrote about the Central Tabernacle in a 1913 article in The Comforter. He explained that the building was erected by the Presbyterians who in turn rented it to the Catholic Apostolic Church in Zion (referred to as the "Zion Church") which was under the supervision of Zion Overseer Daniel Bryant. See P.L. Le Roux, "The Central Tabernacle," The Comforter, October 1913, 2.

108 De Wet, The Apostolic Faith Mission in South Africa, 52.

${ }^{109}$ Cathy Crompton and Audrey Ryan, God in Action: Revival in South Africa. (Port Elizabeth, South Africa: Crompton Ministries, 1994), 7. See also: Burton, When God Makes a Pastor, 34.

${ }^{110}$ Frank Chikane, "The Blessings of Azusa Street and Doornfontein Revivals and Pentecost's Blind Spot" in Harold D. Hunter and Cecil M. Robeck, The Azusa Street Revival and lts Legacy. (Cleveland, TN: Pathway Press, 2006), 261.
} 
The revivals in Johannesburg reflected the same diversity of participants as Azusa. In addition to white Afrikaners and black Natives, the mission also evangelized to Jews, Indians, and Coloureds. In a letter published in The Pentecost, Lake claimed that "From 200 to 300 Jews attend every service."111 While that number may sound high, Johannesburg was home to more than half the country's Jewish population in the post-South African War years. ${ }^{112}$ Burton recounts how the governess of Johannesburg's chief Jewish Rabbi attended and witnessed the conversion and spiritual baptism of a Spiritualist, whereupon "she was amazed to hear this exspiritualist extolling the Lord in pure Hebrew." ${ }^{113}$ The group, and Lake in particular, tried to integrate the services as it was at Azusa. The group claimed success in recruiting mission workers from all backgrounds. "God has already raised up a score of workers consisting of English, Dutch, and natives of various tribes who are baptized with the Holy Ghost, and the signs follow them as well as they do us" wrote Lehman in December, 1908. ${ }^{114}$

Despite the cultural and ethnic diversity of the first awakening, a dominant feature of the affair was the class of the congregants. The group was most

\footnotetext{
111 The Pentecost, September 1908. 2.

112 For more on the Jewish population in South Africa see: Louis Herrman, A History of the Jews in South Africa from the Earliest Times to 1895. (Westport, Conn: Greenwood Press, 1975), 23840; G. Saron and L. Hotz, The Jews in South Africa: A History. (Cape Town: Oxford University Press, 1955); Leybl Feldman and Veronica Belling, The Jews of Johannesburg: (Until Union--31st May, 1910). (Cape Town: Isaac and Jessie Kaplan Centre for Jewish Studies and Research, University of Cape Town, 2007); Marcia Gitlin, The Vision Amazing; The Story of South African Zionism. (Johannesburg: Menorah Book Club, 1950); and Margot W. Rubin, The Jewish Community of Johannesburg, 1886-1939: Landscapes of Reality and Imagination. (M.A. Thesis: University of Pretoria, 2004).

113 Burton, When God Makes a Pastor, 33.

114 The Pentecost, December 1908, 2.
} 
successful in converting poor blacks and poor Afrikaners - the two groups most harmed by the South African War. ${ }^{115}$ They also comprised the majority of the city. The biggest field by far lay in the mission to the miners. The goldminers were a captive and concentrated audience. Lake wrote that "In the last three or four years the natives from the very interior of Africa have been coming to Johannesburg to work on the mines. They live in the compounds and on any Sunday forenoon you can address 2,500 natives in most of the compounds." 116 Yet these two groups were also socially at odds during this period, as poor Afrikaners were competing with poor Africans for jobs.

As an epicenter of the Transvaal, Johannesburg was ideally situated for the Pentecostal missionaries. Visitors to the mission returned to their homes across the countryside with tales of their personal experiences and stories of the revival. ${ }^{117}$ Lake, Hezmalhalch, and other workers frequently traveled to areas in Pretoria and the surrounding countryside as evangelists, holding services wherever they went. "Lake was nothing of a teacher" wrote Burton, but he was apparently quite good at public speaking, so Lake would deliver the fiery sermons, leaving the more intricate and nuanced teaching to Thomas Hezmalhalch. ${ }^{118}$ One successful tactic for proselytizing in Johannesburg was to

\footnotetext{
115 Matthew Clark, "Mission Effort in the Apostolic Faith Mission of South Africa," Transformation: An International Journal of Holistic Mission Studies 26, no. 3 (2009): 174-185. 176.

116 The Pentecost, December 1908, 7.

117 David Du Plessis and Bob Slosser. A Man Called Mr. Pentecost. (Plainfield, N.J.: Logos International, 1977), 106.

${ }^{118}$ Burton, When God Makes a Pastor, 35.
} 
hold services with Christian associations in order to gain access to those who might be accepting of the Pentecostal message. In 1908 the group was holding services at the local YMCA, speaking in several local Baptist congregations, and holding services at Bethel mission, a mission dedicated to working men. ${ }^{119}$ "Precious hungry missionaries from all about attend these meetings" wrote Lake. $^{120}$

From the beginning the Johannesburg group replicated both the message of Pentecost and the practice of spiritual gifts of the Apostolic Faith Mission of Los Angeles. Descriptions of divine healing permeated all discussions of the revival in the written record. The mission's newspaper recounted the testimonies of those healed extensively. "I was a consumptive for many years," wrote one miner, "I received my discharge from the Remout Depot for being "medically unfit." I obtained employment in the Premier mine. Here again I was rejected by the company's doctors. He declared I could not live for three months..." Then one night, "the Brethren prayed for me at the Tabernacle. Next morning I had no cough, no haemorrhage [sic], and no pain whatever. I was healed." The miner concluded with proof of his employment: "Since my wonderful healing, I have worked underground for two years. I am now employed as a miner on the Wolhuter Deep Gold Mining Company." ${ }^{21}$ Consumption was a commonly reported healing. Others included cancer, bronchitis, blindness, deafness,

\footnotetext{
119 The Pentecost, August 1908, 7.

120 The Pentecost, August 1908, 7.

121 The Comforter, September 1910, 1.
} 
lameness, mental illness, and curvature of the spine. ${ }^{122}$ Many likewise claimed to be healed from their addictions to alcohol and tobacco, and news of the miraculous healings spread quickly via word of mouth. Like Azusa, the revival in Johannesburg was met with some hostility by the European churches and established missions. A witness described a visit from Lake to a Dutch Reformed Church in Ladybrand, where several members "received the Holy Ghost" and witnessed "a healing from an incurable case of dropsy, to the amazement of the doctors and the public." "But in spite of all," the attendee wrote, "these Apostolics were despised and avoided and their names struck from the church register."123 Yet one AFM member recounted that "The established churches only gave the work publicity by preaching against it."124

The group drew from their experiences of Azusa and the healing circuits in the U.S. in their evangelization methods in Johannesburg. In a pamphlet they sent out announcing their arrival to Johannesburg in August 1908, the group declared "This is God's evangelization movement." ${ }^{25}$ Their message was not entirely foreign to the ears of their listeners. As Bengt Sundkler notes, the Los

\footnotetext{
122 The Comforter, September 1910, 1, 7-8; and God's Latter Rain, November 1908, 3-4.

${ }^{123}$ David Du Plessis, "My Experience in Pentecost for 43 Years," Papers of David Du Plessis, 1900-1987 Collection, Box 1, Folder 1, David Du Plessis Archives, David Allan Hubbard Library, Fuller Theological Seminary, 7.

${ }^{124}$ Du Plessis and Slosser. A Man Called Mr. Pentecost, 106.

125 The Forerunner of "God's Letter Rain," August 1908, 4. Reprinted in John G. Lake: The Complete Collections of His Life Teachings, compiled by Roberts Liardon, (New Kensington, PA: Whitaker House, 1999), 47.
} 
Angeles Apostolic Faith periodical beat the arrival of the Pentecostals to South Africa, thus preparing the way for them in some circles. ${ }^{126}$

The Pentecostal message appealed not only to a diverse audience, but it drew specifically on the same attraction exercised by Zionist churches. Indeed, it not only drew on that same group, it drew from - and drained - those actual Zionist churches themselves. This was not unexpected, since the Zionist churches were connected with Dowie's Zion City ministries in America. The Zionist churches were initially white, but had established a foothold in Zulu communities who had embraced the religion. ${ }^{127}$ Hezmalhalch and Lake immediately made contact with these missionaries and established contacts so that they might present their new doctrine. Lake knew Overseer Bryant from the Zion Apostolic Christian Church of South Africa, and made contact with him prior to their arrival. ${ }^{128}$ Bryant seemed accepting of the Pentecostal message and had instructed his congregants to seek "a deeper experience with God" and for the baptism of the Holy Ghost. Bryant had however left for America just as the group was arriving. ${ }^{129}$ The Zionists in Johannesburg provided the AFM with the Central

\footnotetext{
126 Sundkler, Zulu Zion and Some Swazi Zionists, 52.

${ }^{127}$ Bengt Sundkler details the reasons for why Zulus favored Zionist teachings. He argues that the years after the Boer War, the country was devastated and there was famine, which led many Africans to embrace more apocalyptic versions of Christianity. Furthermore, the Zionists were less strict in their rules for holy living than other denominations. Unlike other Protestant missionaries, for instance, Zionists did not require Africans to disavow polygamy, a practice with deep ties in certain cultures. See Sundkler, Zulu Zion and Some Swazi Zionists.

${ }^{128}$ Lake had served as an elder in the Zion Apostolic Christian Church in Zion City, IL under John Alexander Dowie before converting to the Pentecostal movement so he still had many connections with the Zionists.

${ }^{129}$ Burton, When God Makes a Pastor, 31.
} 
Tabernacle and congregation almost immediately adopted the teachings of the missionaries. Shortly afterwards, the group succeeded in consolidating other Zionist and Ethiopian churches in Johannesburg with the AFM. In January 1909 the leaders of the AFM met with "four native brethren representing congregations of the Ethiopian Catholic Church in Zion" in order to discuss joining the AFM. The AFM leaders asked the "native brethren" to submit their resignations to the Ethiopian church, after which they accepted them as full members in the Apostolic Faith Mission. ${ }^{130}$

Zionist and Ethiopian Churches felt a strong connection to the AFM for several reasons. First, Le Roux was a former Zionist and had the trust of many in the Zionist Churches. ${ }^{131}$ Second, the theology of the AFM was very similar to Zionist theology and the doctrine of Holy Ghost Baptism fit well within the traditional African religious worldview. Lastly, the worship and practice of Pentecostalism as an experienced faith over that of a creed or doctrine-based Western faith fit more easily into African culture.

As with Azusa, the South African Pentecostals worked out some institutional order for the faith. Although they had shunned ecclesiastical organization in the beginning, and many members were still wary of ecclesiastical structure of the mission, the group organized assemblies in an

\footnotetext{
${ }^{130}$ Apostolic Faith Mission Executive Council Meeting Minutes, January 2nd, 1909. 17. Apostolic Faith Mission Archives, Auckland Park Theological Seminary, Auckland Park, Johannesburg, South Africa.

131 Sundkler, Bengt. Zulu Zion and Some Swazi Zionists, 53.
} 
amalgam of Presbyterian and Episcopal polities. ${ }^{132}$ Conferences were annual events at which leaders from all the assemblies would meet to discuss mission policies, doctrines, and fellowship together. In May 1909 fifteen of the workers gathered together to form and nominate an Executive Council. They passed a resolution stating:

The brethren present constitute themselves into a council, which consists of all the workers in active service for the Master, who teach the Gospel of Jesus Christ accordingly in the Word of God and maintain the same as set forth in the Apostolic Faith Mission. The workers shall maintain full liberty in the Holy Ghost, independent of each other, each worker being acknowledged as the head of the work thus undertaken by him, with whom the other workers will cooperate if required. ${ }^{133}$

Thus the mission's ecclesiastical organization was established from the beginning with autonomy as one of its main features. The Executive Council served as the organizational authority of the mission when matters of expediency arose and could not be addressed by a general council. They elected Thomas Hezmalhalch as President, John G. Lake as Vice President, H.M. Twiney as Treasurer, and J.H.L. Schumann as Secretary, with Lehman, Van de Wall and Elliott serving as additional members. ${ }^{134}$

The group used a hierarchy of committees for organization and to help share the workload of the mission. At the top was the Central Tabernacle, which

\footnotetext{
${ }^{132}$ Assemblies were local congregations of the AFM. They were churches in all but name, as the AFM distanced themselves from the term "Church."

${ }^{133}$ Apostolic Faith Mission Executive Council Meeting Minutes, May 27th 1909, 34. Apostolic Faith Mission Archives.

${ }^{134}$ Apostolic Faith Mission Executive Council Meeting Minutes, May 27th 1909, 34-35. Apostolic Faith Mission Archives.
} 
Lake called the "mother church of this movement." 135 Likewise, Letwaba wrote in a letter that "we pray for you and all the dear Saints in the Mother Church at 88 Bree Street."136 The group passed their first constitution in 1911, which included the formation of a "Spiritual Committee" which was designed to unify the mission's theology and doctrines. At least one member was unhappy with entrusting a committee with this task, as it gave the Spiritual Committee broad authority. Lake argued that the power previously rested with the Executive Council and so this was simply a delegation of powers. ${ }^{137}$

In April 1910 they passed a series of resolutions that together comprised their first missionary policy. ${ }^{138}$ Lake was especially passionate about the "native work," as he noted:

In no department of the work of God through the Apostolic Faith Mission in South Africa, has a greater demonstration of God's power to save and heal and baptize in the Holy Spirit been manifested than in the Native work. We feel that there is a lack of appreciation of the mighty work God is doing among the natives...A fact not duly appreciated is that the vast majority of native work is being conducted by natives themselves, without white assistance, -except in the general direction and superintendence through the Executive Council in Johannesburg. We feel that our friends abroad especially lack in appreciation of what God is doing among the natives in South Africa; no doubt it is because that Pentecost in general, in other lands is largely confined to small missions, operating locally; this work is not so, but it is rather a great systematic evangelizing movement, extending practically from the Cape to the Zambesi, and from ocean to ocean. We even have our representative native workers scattered through Central and Northern Africa, as far north as the Sahara Desert, and expect

\footnotetext{
135 Published letter from John G. Lake to mailing list of AFM. April 30th, 1911. 2. Apostolic Faith Mission Archives.

136 The Comforter, October 1913, 12.

${ }^{137}$ Apostolic Faith Mission Executive Council Meeting Minutes, November 3rd, 1911. 85. Apostolic Faith Mission Archives.

${ }^{138}$ De Wet, The Apostolic Faith Mission in Africa, 1908-1980, 95.
} 
soon that a number of our native workers will open work beyond the Sahara. ${ }^{139}$

This quote illuminates the central internal struggle within the AFM between the mission work and the institution. The fight would become more pronounced as time went on, with the American missionaries being far more inclined to continue the mission for the sole purpose of evangelizing, and the Afrikaner portion of the mission desiring more stability and organization. The mission work required the heavy involvement of native workers, who could preach and translate into the various languages of the people in the countryside. Lake's statements support what many other historians have found to be true in the mission context of South Africa; that namely it was often native workers who spread the gospel throughout the country. ${ }^{140}$

Despite the original outpouring of the spirit and the rapid expansion of the awakening, problems of the original witnesses multiplied. First, racial discord among the members proved to be a difficult obstacle for the mission. From the beginning, the leaders of the AFM were all white, despite there being many educated African pastors and workers within their ranks. Women were likewise

139 The Comforter, July-August 1911, 10.

140 There are many works that examine the role of native missionaries in the missionizing process, with scholars generally falling into two camps of thought. Historian Richard Grey has argued compellingly that widespread religious change in Africa was not due to missions or missionaries, but rather to African evangelists. Others like Shula Marks have also advocated for African agency, but have asserted that Africans have often "become accomplices in their own subjection." See: Richard Gray, Black Christians and White Missionaries. (New Haven: Yale University Press, 1990), 80; Shula Marks, The Ambiguities of Dependence in South Africa: Class, Nationalism, and the State in Twentieth-Century Natal. (Baltimore: Johns Hopkins University Press, 1986), 8. See Also: Edward E. Andrews, Native Apostles: Black and Indian Missionaries in the British Atlantic World; Jean and John L. Comaroff, Of Revelation and Revolution: The Dialectics of Modernity on a South African Frontier V.I\&II.; and Bengt Sundkler, Bantu Prophets in South Africa. 
excluded from leadership positions despite playing a heavy role in other areas of the mission. ${ }^{141}$ In these areas, they did not replicate the social radicalism of Azusa.

The exuberance of the missionary writings and their numerical evangelical successes obfuscate many personal and financial difficulties during these early years. On December 22, 1908, just seven months after landing in South Africa, Jennie Lake died from an unknown illness. Despite the mission's success at converting hundreds to the movement, the core group suffered financially due to the autonomous nature of the mission. Burton wrote:

It is strange to realize that, during this time, with thousands being saved and healed, the little missionary party was often in the direst need. It is true that some faithful souls would occasionally leave a basket of food at the door, or help with clothing for the big Lake family. Yet on the whole the people did not think of the supplies, believing that Lake must be supported by some society overseas. ${ }^{142}$

This left Lake with seven young children to provide for in addition to his work at the Apostolic Faith Mission. ${ }^{143}$ Jennie Lake's death marked a period of extended silence. The mission failed to publish another issue until September 1910, under the new title "The Comforter and Messenger of Hope." In the meantime, Lake left for England and America to visit churches, spreading the news of the AFM in South Africa and recruiting more workers for the mission. ${ }^{144}$

\footnotetext{
${ }^{141}$ The spouses of missionaries, ministers, and evangelists were treated as co-pastors of a marital team. They could minister in many of the ways their spouse could.

142 Burton, When God Makes a Pastor, 45.

${ }^{143}$ Lake's sister cared for the children after Jennie's death.

144 P.A. Minnaar and H.J. Scheppers, "John G. Lake." 1. Typed document in Apostolic Faith Mission Archives, Auckland Park Theological Seminary, Auckland Park, Johannesburg, South Africa.
} 
During the first two years the international Pentecostal print network sustained the mission, arguably keeping it from dissolving entirely from lack of funds. Although the groups did not keep records of their finances during this time, the editor from The Upper Room noted in November 1910 that seven months' worth of donations from readers in the amount of $\$ 2,200$ had been sent to John G. Lake in particular, as well as "considerable funds to Bros. Schwede and Letwaba for their work in the Waterberg district and also to other workers in South Africa." ${ }^{145}$ During this time the American missionaries consistently wrote to various US publications to keep news of the mission present in the international network. Elias Letwaba, an African convert, was also frequently published in The Upper Room. Lake wrote extensively and his letters were published in The Pentecost, The Upper Room, and other publications. Because of the Pentecostal print network, American Pentecostals sometimes heard of the Doornfontein revival before South Africans.

During the earliest years of the mission, the witnesses themselves continued to keep the American - and international - movement alive to the circumstances of the revival. A 1909 letter from Charles Kaepper to John Lake illustrates the complexity of the network that linked these initial Pentecostals worldwide:

A friend of mine has sent me some papers from Los Angeles - The Upper Room - in which I found a letter from you about the work of the Lord in South Africa, and a preacher with the name of P. E. Le Roux who is in need of some money... Now, my dear brother Lake, as I have no address for Bro. Le Roux, I send you this money order of $\$ 50$. Please forward the

145 "South Africa and Brother Lake," The Upper Room, November 1910, 2. 
name to that dear man of God and tell him a special gift from God, through a brother in Christ whom he never saw nor knew. ${ }^{146}$

The mission's address was published in the periodicals and the testimonies and reports from Lake, the Hezmalhalchs, Sackett, and the Lehmans attracted contributions and American Pentecostals desiring to join the mission field. Lake traveled extensively during this period as well, working exhaustively to promote the mission internationally.

Five years after the arrival of the American evangelists, the Apostolic Faith Mission was fully established and growing in numbers. Despite personal and financial setbacks, the mission had survived through their evangelical work on the ground and through reliance on the 'pneuma network' of Pentecostals worldwide, who funded the missionaries through periodicals. The year 1913 would however witness a sharp turn in the direction of the Apostolic Faith Mission, due to the departure of the Americans Lake and Hezmalhalch, and the turnover of the AFM leadership to white South Africans. Lake left South Africa in February 1913 for an anticipated six month leave from the Apostolic Faith Mission. ${ }^{147}$ He never returned.

\footnotetext{
146 Letter from Charles Kaepper to John G. Lake, June 15th 1909. Apostolic Faith Mission Archives, Auckland Park Theological Seminary, Auckland Park, Johannesburg, South Africa.

147 The Comforter and Messenger of Hope, October 1913, 8.
} 


\section{CHAPTER 5: \\ THE COMFORTER AND MESSENGER OF HOPE}

This chapter investigates the role of the Apostolic Faith Mission's periodical The Comforter, in the early years of the mission in South Africa. While various sources exist for understanding and analyzing the earliest days of the Pentecostal movement in South Africa, the movement's periodical, The Comforter, offers some of the most vivid illustrations of what was going on among the revivalists. It does so in various ways. First, it introduced the Pentecostal movement to the South African context; second, it effectively standardized the movement itself and the critical theological tenants of Pentecostalism; third, it became a kind of sacred text itself; fourth, it created and confirmed the community of witnesses within the country, fifth; it established and validated the South African witnesses in the global fellowship of Pentecostals and served as an instrumental recruiting tool for missionaries for the country; finally, it validated some of the most fundamental elements of the movement in its affirmation of universalism.

As in America, Pentecostal periodicals played a defining role in building the movement in South Africa. Having witnessed the influential impact of The Apostolic Faith at Azusa, the Apostolic Faith Mission group wasted no time in replicating the periodical in Johannesburg, and defining themselves as part of the larger Pentecostal movement. They quickly began production on a Pentecostal 
periodical, that they titled "God's Latter Rain." The first issue was published in November 1908. Unlike the Apostolic Faith, this periodical was multilingual. Printed in half English and half Dutch, it catered to the bulk of the literate public. ${ }^{2}$ The paper replicated the multiracial elements of the former paper as well, by listing testimonies and news from non-white Apostolic Faith Mission members.

After that first issue, the group was not able to print another paper until

September 1910. This time they updated the name to The Comforter and Messenger of Hope.

The initial publication committee was comprised of J.H.L. Schumann, Archd H. Cooper, John G. Lake, J. Osborn, HY Ulyate, J.O. Lehman, and Thomas Hezmalhalch. ${ }^{3}$ The group nominated H. M. Powell as the Editor of the paper. ${ }^{4}$ The group had published a booklet entitled The Forerunner to God's Latter Rain the previous August, which gave notice of the group and its mission, as well as an address where correspondence and financial contributions could be sent. Tithes and financial contributions allowed the mission to print 3,000 copies of the first issue of the periodical. ${ }^{5}$ The publication committee changed in 1913

\footnotetext{
${ }^{1}$ Changed later to "The Comforter and Messenger of Hope" or "De Trooster" in Afrikaans.

2 The initial issues were in English and Dutch (See The Comforter, September 1910, 2, November 1910, 2, and the Albert E. Sharpe, Treasurer, insert in the May-June 1911 issue). R.H. van de Wall was the Editor of the Dutch paper. The Executive Council committee considered a proposal to edit the Trooster in Afrikaans in 1923, but did not follow through until 1930 ( $D e$ Trooster, May 1923, 12-13). Afrikaans and Dutch are very similar in written form, as Afrikaans has a more simplified vocabulary from Dutch.

${ }^{3}$ God's Latter Rain, Nov. 18 ${ }^{\text {th }}, 1908.1$.

${ }^{4}$ AFM Executive Council Minutes. August 22nd, 1910. 62. Apostolic Faith Mission Archives.

${ }^{5}$ God's Latter Rain, Nov. $18^{\text {th }}, 1908.1$.
} 
with the election of a new Executive Council. The 1913 issue lists P.L. Le Roux as Editor, Charles Welsh as Treasurer, Scoff Moffat as Secretary, and W.F. Dugmore as in charge at the Vestry Tabernacle. ${ }^{6}$

The first issue, entitled God's Latter Rain, appeared on November 18th, 1908 and introduced the Pentecostal movement to the Johannesburg audience. The group explicitly linked the mission as an extension of the Azusa Street Revival. On the front page they introduced themselves:

Who are we? And what do we teach and practice? We are known as the Apostolic Faith Movement of Johannesburg, S.A., which is included in the great world-wide Holy Ghost Revival which has taken its impetus from the work at Azusa Street Mission, Los Angeles, California, where the Holy Ghost has been poured out on the believers during the past eighteen months, and which has already spread throughout the entire world. ${ }^{7}$

By linking the movement to Azusa instead of Topeka, the group confirmed the Los Angeles revival as the origin point for the movement. To dispel the notion that they were just another mission church, they contended that "This is not a movement of man. It is God, by His Spirit, moving the hearts of men everywhere, as we believe, in preparation for the soon coming of our Lord and Saviour Jesus Christ. (Matth.24)"8 By emphasizing the spiritual over the ecclesiastical, the group helped to differentiate themselves from the mission and mainstream churches.

As proof they offered several characteristics:

An element of spontenuity has characterized this work from its inception. The work in many places throughout the world appearing within a very

\footnotetext{
${ }^{6}$ The Comforter, October 1913, 8.

7 God's Latter Rain, Nov. 18 ${ }^{\text {th }}, 1908.1$.

8 God's Latter Rain, Nov. $18^{\text {th }}, 1908.1$.
} 
short time, the same characteristics accompanying it, indicating that it is not the production of man but the operation of the Holy Ghost in the Baptism of power in the pouring out of His Spirit upon all flesh. ${ }^{9}$

By branding Pentecostalism in opposition to denominationalism, they avoided being labeled as simply yet another church seeking to establish a foothold in the country. They declared "We have no human creed. We stand for the word of God alone as the infallible rule of faith and practice." ${ }^{10}$ They viewed themselves as simply there to present the gospel and save as many souls as possible until the imminent return of Christ. The proof was in the successful spontaneity and the similarities with the early apostolic church.

The editors offered several points of evidence to substantiate their claim of the spiritual authenticity of the movement. They connected the phenomenon of Holy Ghost Baptism to the first Pentecost, saying "Believers who received the baptism of the Holy Ghost received the conformation of speaking in tongues as the believers did on the day of Pentecost: (Acts 2:) and recorded at the household of Cornelius; (Acts 10:44-46) and at Ephesus (Acts 19:1-6)."11 They pointed to the success of their publishing press as further evidence that the movement was of God, saying,

Another characteristic of this work is the liberality manifested in the publication of periodicals gratuitously. Up to this time we have hardly known of any paper existing on the gratuitous plan, but since this latter rain has made its appearance, not less than about twenty different papers,

\footnotetext{
${ }^{9}$ God's Latter Rain, Nov. $18^{\text {th }}$, 1908. 1.

${ }^{10}$ God's Latter Rain, Nov. 18 $8^{\text {th }}, 1908.1$.

${ }^{11}$ God's Latter Rain, Nov. 18 $8^{\text {th }}, 1908.1$.
} 
which have a large circulation throughout the world, have sprung up and are maintained by the free will offerings of their readers. ${ }^{12}$

They also offered their lives as examples of how God had directed the movement, affirming that

The same spirit characterizes the workers as they go from place to place, and from country to country, being sent by God, without guarantee of support by any board save Phil. 4:19; no collections taken nor solicitation of support made, the individual relying solely on God for sustenance. ${ }^{13}$

Finally, they pointed to their particular style of worship as a unique characteristic of the movement.

With the outpouring of the Holy Ghost at Los Angeles, California, came the abundant liberty of the Spirit that characterises [sic] the Pentecostal Movement everywhere. A soul moved by the Spirit would in obedience arise and deliver a message, sing, pray, exhort, etc., in any public service. So great was the change from the old strict church method of worship that people had been accustomed to, that this manner of worship very soon began to be recognised [sic] as Pentecostal. ${ }^{14}$

These articulations demonstrate a certain degree of religious branding, whereby the Pentecostals distinguished themselves from other religious groups that they implied were not so Spirit-filled. Through The Comforter, they "branded" Pentecostalism as that of an authentically Spirit-led movement, as opposed to a man-led institutional church.

Without any structural institutions that might provide theological training, the AFM relied on The Comforter to standardize the theology of the young movement. The first paper confirmed Holy Ghost baptism, with evidence of

\footnotetext{
${ }^{12}$ God's Latter Rain, Nov. $18^{\text {th }}, 1908.1$.

${ }^{13}$ God's Latter Rain, Nov. 18 $8^{\text {th }}, 1908.1$.

14 The Comforter, September-October 1911, 5.
} 
speaking in tongues as one of the mission's central theological tenants. ${ }^{15}$ The first issue likewise contained a few testimonials from those who claimed to have received Holy Ghost baptism with tongues as a sign. The second issue in 1910 contained a lengthy editorial and articles that expounded on the theology of regeneration, sanctification, and Holy Ghost baptism, promising the readers "if you are willing to go all the way with God, a Pentecost awaits you." ${ }^{16}$ In one regard the editors seemed to differ from the initial interpretation of tongues at Azusa. Instead of arguing that tongues were a real foreign language, the editors quoted from Conybeare and Howson's The Life and Epistles of Saint Paul," suggesting "it was not knowledge of foreign language as is often supposed," but rather "the believer was constrained by irresistible power to pour forth his feelings of thanksgiving and rapture in words; yet the words which issued from his mouth were not his own; he was usually even ignorant of their meaning." ${ }^{17}$ This was significant step away from the original interpretation of tongues, but it was a theological trend that was taking place in America as well, as Pentecostals there renegotiated their theology.

The practice of divine healing was not new to South African Protestants, ${ }^{18}$ but through The Comforter, the Pentecostals connected the practice with the

\footnotetext{
${ }^{15}$ God's Latter Rain, Nov. $18^{\text {th }}, 1908,1$.

${ }^{16}$ The Comforter, September 1911, 3.

17 The Comforter, September 1911, 5.

${ }^{18}$ Andrew Murray adopted the teaching of divine healing, but the practice was not viewed as scripturally sound by most established Churches. De Wet quotes Oosthuisan as saying "Even Dr. Andrew Murray, the most revered DRC minister in his time 'plainly stated that Divine Healing was the teaching of the Word of God - a glorious, Divine truth,' but warned that if he insisted on proclaiming it in public, he might be, 'put aside, as the church would not allow it in its public
} 
Pentecostal theology of Holy Ghost Baptism. In the news of revivals, the descriptions almost always list in order the process of people being first saved, then baptized in the Holy Ghost with evidence of speaking in tongues, and finally physically healed. A typical account read:

The crowds flowed in, hundreds were saved, and numbers baptized in the Spirit, with the sign of speaking in tongues. The sick and the suffering came and received their healing. There was great rejoicing. The presence and power of God became more real and evident, and lives were endued with real power. ${ }^{19}$

By connecting these three elements in the accounts, the paper fused together the notion that Holy Ghost Baptism precipitated divine healing. In his dissertation on the AFM, Christiaan De Wet argues that "One would make... a grave error in underestimating the important role... that healing has played as a positive growth factor in the AFM in Africa. Indeed, as it was and still is in the growth of the African Independent Churches." ${ }^{20}$ As some scholars have suggested, black South Africans found the theology of divine healing to be consistent with their traditional worldviews, and therefore were more open to the practice than white South Africans. In his study on race relations within Pentecostalism, lan Macarthur writes that there are:

some elements in the Bible which could be interpreted in terms of African religion and thus provide a continuity of belief and practice. The Scriptures speak of miracles, the exorcism of demons, the defeat of Satan and the granting of the Spirit's power to believers that they might do such things. ${ }^{21}$

\footnotetext{
ministry of the Word."' De Wet, The Apostolic Faith Mission in Africa, 1908-1980, 32.

19 The Comforter, October 1913, 2.

${ }^{20}$ De Wet, The Apostolic Faith Mission in Africa, 1908-1980, 371.

${ }^{21}$ lain MacRobert, The Black Roots and White Racism of Early Pentecostalism in the USA. (New
} 
The writings from the Pentecostal missionaries, workers, and ministers substantiate this claim. Lake wrote often of the miraculous healing that he had witnessed and of the mission's success. "Seventy-five percent out of every hundred who come are healed" wrote Lake in September 1908 to the editors of The Latter Rain Evangel. ${ }^{22}$ Full of drama and description, they were an engaging read for subscribers. While many missionaries wrote general accounts of large numbers of people being healed of blindness, deafness, or lameness, they also frequently gave detailed descriptions of individual healings that provide a glimpse into their minds. "To lay your hands on a woman with dropsy, with legs as large as a big stove pipe, and see them diminish and become natural while you pray has been the experience of the past week," wrote Lake. He continued "To see a tumor of twenty pounds burst and run off as you pray is another manifestation of the power of God."23

The Pentecostals fought against the "doctrine of suffering" which they believed hampered the belief and conversion of people to Christianity. Scott Moffat, writing in The Comforter in 1913, explained that "There are many good people in the world today who live under the settled belief that sickness, pain and bodily affliction are God's ministers of grace. To such I would say 'God has in these days shown us a better way.' To say that sickness is a means of grace, is

\footnotetext{
York, NY: St. Martin's Press, 1988), 16.

22 John G. Lake, Letter republished in The Latter Rain Evangel, November 1908. 13.

${ }^{23}$ John G. Lake, Letter republished in The Latter Rain Evangel, November 1908. 13.
} 
to materialize a great Spiritual principle."24 These extensive theological articles on the doctrine of divine healing helped to differentiate the Pentecostals from other missions in South Africa. Most other Protestant missions did not hold to the continuation of spiritual gifts and instead focused on building hospitals and doctors to care for the ill. ${ }^{25}$ The Pentecostals were radically different, going so far as to shun medical advice from doctors, the use of medicine, and vaccinations.

Divine healing provided proof of Pentecostal theology to readers an ocean away. The accounts contributed to the idea that people were living in the end times and God was indeed pouring out his Spirit on His people, endowing them with supernatural powers in order to save souls. Lake became something of a celebrity in the city because of the healing ministry. ${ }^{26}$ "Lake's name was on everyone's lips," wrote Burton. ${ }^{27}$ In a 1912 editorial in The Comforter, Lake

\footnotetext{
24 The Comforter, October 1913, 6.

${ }^{25}$ See: Hines Mabika, "History of Community Health in Africa. The Swiss Medical Missionaries' Endeavour in South Africa". Gesnerus. 72, no. 1 (2015): 135-158; Hilary Ingram, Gender, Professionalism and Power The Rise of the Single Female Medical Missionary in Britain and South Africa, 1875-1925. (M.A. Thesis, McGill University, 2007).

<http://digitool.Library.McGill.CA:8881/R/?func=dbin-jump-full\&object_id=18456>; Karen Elizabeth Flint, Healing Traditions: African Medicine, Cultural Exchange, and Competition in South Africa, 1820-1948. (Athens, Ohio: Ohio University Press, 2008); Martina Egli and Denise Krayer, Mothers and Daughters: The Training of African Nurses by Missionary Nurses of the Swiss Mission in South Africa. (Lausanne: Le Fait Missionnaire, 1997); and Siphamandla Zondi, African Demand and Missionary Response: The Emergence of Missionaries As Healers in KwaZulu Natal, 1835-1930. (Cambridge: Currents in World Christianity Incorporating North Atlantic Missiology Project, 1998).

${ }^{26}$ Lake had prior experience traveling as a healing evangelist in the U.S.

${ }^{27}$ Burton, When God Makes a Pastor, 42.
} 
claimed that "our records show the healing of 2,023 people during the year 1911."28

The Pentecostals' theology of spiritual healing differentiated them from other Christians and enamored them to Africans who found their theology more similar to that of native beliefs. In a 1911 letter to Carrie Judd Montgomery, Lake expressed that "We do not pray for God to come and heal as in the old days." 29 Instead of asking God for healing, the Pentecostals believed that they were endowed with the power of the Holy Spirit to command demons and illnesses to leave the sick. This emphasis on individual agency of the believer would prove very attractive to black Africans who desired greater autonomy. Lake continued, "It was only after I had received the Baptism of the Holy Ghost, that the dominion of God entered into my soul that compelled me to command sicknesses and the devil to leave, rather than to intercede with the Lord to take them away." ${ }^{30}$

By including the actual names and addresses of those who wrote in testimonies of healing, the editors of The Comforter maximized the perceived truth of the author. The group did not use pseudonyms, and the practice of including names and addresses gave the readers real names to pray for and addresses to which they might send letters of encouragement. This served to

${ }^{28}$ The Comforter, February 1912, 5.

${ }^{29}$ Letter from John G. Lake to Carrie Judd Montgomery. April 22nd, 1911. Flower Pentecostal Heritage Center Archives. Springfield, MO. 1.

${ }^{30}$ Letter from John G. Lake to Carrie Judd Montgomery. April 22nd, 1911. Flower Pentecostal Heritage Center Archives. Springfield, MO. 2. 
establish a loose-knit, yet strong community of believers. Frequently, authors would note that a reading of The Comforter brought on the particular spiritual episode or healing in question.

The special emphasis on divine healing was unsurprising given Lake's personal background and the religious background of the other missionaries, combined with their close ties to the Zionists. Claims of healing were often of illnesses that would have been difficult to prove as being cured. However, particularly in the initial years, many claims of healing were of those who were blind, deaf, crippled, or mute. The Pentecostals insisted that these claims were "no exaggeration" and hundreds were healed at services. ${ }^{31}$ The numbers vary. Typically stories would include the mention that a substantial majority of those who were prayed over or who had hands laid on them were "instantaneously" healed. Generally, it was over seventy percent. In a 1908 December issue of The Pentecost, an anonymous report from South Africa stated that "Instantaneous healings used to be the exception, today they are the rule."32

It is clear that both American and South African Pentecostals struggled with false claims of faith healing, as well as skeptics who claimed that no one was actually being healed at all. Lake in particular fought against the practice of what he termed "Dollar Christianity," lamenting that "because of the commercialized state of evangelistic work, evangelists felt that they could not

\footnotetext{
31 The Pentecost, December 1908, 1.

32 The Pentecost, December 1908, 11.
} 
afford to take time to pray for the same individual more than once; and in a short time they began to teach that accursed teaching that has devastated the ministry of healing that it was only proper to pray for the sick once, that they should not be ministered unto the second time. This was Dollar Christianity." ${ }^{33}$ In 1910 the editors published statements from a group of leading scientists in the British medical profession on their perception of faith healing after observing some cases. They quoted Sir Thomas Clifford Allbutt (20 July 1836 - 22 February 1925) as saying "probably no limb, no viscus is so far a vessel of dishonor as to be wholly outside the renewals of the Spirit." Sir William Osler, (July 12, 1849 December 29, 1919), a leading Canadian physician and one of the founding fathers of John Hopkins Hospital wrote "our attitude as a profession should not be hostile to faith healing." 34 While the Pentecostals certainly took these statements as professional verification of their work, the original meaning was more complicated. ${ }^{35}$ Nonetheless this appeal to scientific authority on the veracity of faith healing demonstrates a remarkable shift in attitudes towards a more modern understanding of the supernatural. Claims were not enough, they had to

\footnotetext{
${ }^{33}$ Letter from John G. Lake to P.L. le Roux, June 20th, 1935, 2, Apostolic Faith Mission Archives, Auckland Park Theological Seminary, Auckland Park, Johannesburg, South Africa. Reprinted in Burger and Nel, The Fire Falls in Africa, 39.

34 "Eminent British Medical Men on Faith Healing" The Comforter, September 1910, 8.

${ }^{35}$ Osler believed that faith was important to the automatic psychic healing process. He argued that a person who believed they would get better, regardless of the cause, had a better chance at recovery than one who doubted their recovery. See Michael Bliss, William Osler: A Life in Medicine. (New York: Oxford University Press, 2007).
} 
provide observable, demonstrable, and repeatable evidence. Lake, for his part, believed that the proof was obvious when done right.

The Comforter was perhaps most instrumental to workers in the field. Indeed, the Executive Council recognized this as the initial goal of the paper, saying with regard to evangelization, "the workers constitute the first line of attack, but he can be backed by our publications "The Comforter" \& "The Trooster." ${ }^{36}$ Receiving The Comforter every month provided these workers with news of the central mission and their colleagues in other parts of the country. It also provided them with material for their work in the form of sermons and theological articles. In 1918 the Executive Committee noted with concern that there was an "urgent necessity of getting out literature, especially our paper, more regularly. We would have more confidence in sending out comparatively untrained workers if they were being checked and helped by our publications regularly issued." 37

Letters printed in the periodicals indicate that individual subscribers viewed the publication as a medium for communication and interaction within a spiritual community. The editors not only prayed over the periodicals that they sent out but also employed a common practice of healing evangelists by sending out "anointed" handkerchiefs to those who asked for them. The Pentecostals

\footnotetext{
${ }^{36}$ AFM Executive Council Minutes. November 10th, 1913. 117. Apostolic Faith Mission Archives, Auckland Park Theological Seminary, Auckland Park, Johannesburg, South Africa.

${ }^{37}$ Minutes of the Second Annual General Workers' Conference, July 18th, 1918, 205. Apostolic Faith Mission Archives, Auckland Park Theological Seminary, Auckland Park, Johannesburg, South Africa.
} 
referenced Acts 19:12 as biblical evidence for the practice. ${ }^{38}$ These physical objects were understood to hold the same power as that of laying on hands. It was believed that the handkerchiefs were imbued with special spiritual significance, and recipients of these handkerchiefs wrote back their testimonies, which were published in the periodicals: "I received your anointed handkerchief. It was so glad to get it. The moment it came into my hand it felt like the woman we read of, who crept through the crowd and touched the hem of Christ's garment. She felt the power in her very soul, and that same hour SHE WAS HEALED. Brother, it was just the same with me. Praise the Lord for His mighty healing power. Will you pray that I may receive the Baptism of the Holy Ghost."39

The Comforter had several elements that made it a modern periodical. A periodical, as opposed to a newspaper, was comprised of several elements that were favorable to the Pentecostals. First, the periodicals were generally printed once a month, instead of daily or weekly, which determined how they were utilized by readers. This was partly a financial decision, as they could only print the paper as the finances allowed. Newspapers were meant to be quickly consumed, something to be read for consumption at tea for the purpose of learning the news. The Pentecostal periodicals on the other hand, were published generally once per month, and their "news" did not expire. In each issue of The Comforter, readers were greeted with a variety of timeless sermons,

\footnotetext{
38 "So that from his body were brought unto the sick handkerchiefs or aprons, and the diseases departed from them, and the evil spirits went out of them." Acts 19:12, King James Version.

${ }^{39}$ L. Mackenzie, "Healing Through Anointed Handkerchiefs," The Comforter, February, 1912. 4.
} 
prayer requests, news and information about the growth of the movement in faraway lands, letters from missionaries and evangelists, and eons of personal testimonies from fellow believers. These were meant to be read carefully and prayerfully. The editors noted that the workers prayed over each batch of papers that were sent out. Other Pentecostal papers including The Apostolic Faith reported similar practices. ${ }^{40}$ Therefore these periodicals were not to be handled in the same way one would consume and dispose of a newspaper. They were, in effect, sacred texts. The editors asked that when the reader was finished with the issue that they might pass it along to others, that it might reach as many as possible and that they might be touched by it. The papers were even more highly anticipated in rural communities that lack access to reading materials.

Second, they were multilingual and cosmopolitan. The choice to publish the papers in both Afrikaans and English was a deliberate move to bring together as many diverse people as possible. It was costly to print two separate editions of the same newspaper to accommodate for the languages but they made it a priority. In later issues they would print a longer version of The Comforter / De Trooster in English and Afrikaans side-by-side. Their audience was not only the English and Afrikaans-speaking local literate population, but also the larger universal Pentecostal movement. The editors replicated the cosmopolitan message of Pentecost in The Comforter. Missionary letters from places like China, India, and Europe gave the periodical a cosmopolitan character. A 1913

40 The Apostolic Faith (Portland), February 1910, No. 12. 3. 
issue included the following testimony: "A sister writes from Australia saying: 'When I received the anointed handkerchief from you I was suffering very much with neuralgia in the system. I am now free from it. Praise God." 41 Such narrations served to point to the global scale of the movement while at the same time portray an intimate side of the mission and its care for its readers. The editors noted that "Quite a number of requests for prayer have come to us from persons wholly unknown to us. Many of these are for healing from cancer and other incurable diseases. We desire to assure those afflicted ones of the unfailing power of God to heal. Go all the way with Jesus. He will carry you through. We are praying with you." 42

Initially, racial differences were not only downplayed, but discouraged. The first issue included a reprint of a letter from Thomas Hezmalhalch in which he described day-to-day life working as an evangelist in Natal. "A poor conceited soul, who looked upon the Natives as very inferior beings, found by the Spirit of God that considering the advantages in the sight of God she was far worse," he wrote. ${ }^{43}$ Later issues would feature reports and testimonies from native evangelists alongside their Afrikaner counterparts. In these issues, they used the term "brother" or "sister" regardless of the race of the individual. The paper emphasized universal ties emphasized over the local. In a 1924 issue, the paper

\footnotetext{
41 The Comforter, October 1913, 14.

42 lbid.

${ }^{43}$ God's Latter Rain, 1908. 3.
} 
called for the readers to pray for the renewal of America's Christians: "Pray for the revival of America's 'million praying Christians.' Pray for the evangelization of the 50,000,000 unevangelized. Pray for 'a million souls for Christ."'44

Third, the periodical worked on several levels as a form of advertising. They were recruiting tools for foreign mission fields. The mobility that came with technological advances meant that those who read the papers and felt called to go to the foreign mission fields had contacts and addresses, as well as information readily available should they choose to leave. The Apostolic Faith Mission group frequently wrote to American periodicals requesting people who felt "called" to serve to come minister in South Africa. In his letter to Ceilia Smock, Lake wrote:

I do have it in my soul that God wants to use you in America as a recruiting officer and to take up some of these people who have calls and get them out here....There are not only hundreds of thousands of natives, and Chinamen, but there are thousands of Mohammedans and natives of India all over Africa. If they have got a call to India, this is India enough. If they have a call to China, this is China enough. ${ }^{45}$

The papers let readers know when and where meetings were being held, thus providing local advertising for the mission. They also advertised the successes of the movement. In a 1910 issue the editors wrote "In the history of missions we know of none with such a vast work as the Apostolic Faith Mission of South Africa, and that has made such progress with such limited means." 46

\footnotetext{
${ }^{44}$ The Comforter, July-August, 1924, 11.

45 The Pentecost, December 1908, 7.

46 The Comforter, November 1910, 7.
} 
Fourth, the periodical treated subscribers as absent members of the congregation, thereby giving those who lived far away a sense of belonging to a dynamic and cosmopolitan religious community. During a period of particularly difficult financial strain on the paper, the mission put for the following appeal which illustrates this concept:

Through God's grace we have done our utmost to publish the "Comforter" because we know and feel that if it goes out of existence, we are going to lose great influence all over the land and consequently the work of the Lord will suffer. The "Comforter" is a source of blessing to many of our people, who are far away from other believers. We have received many letters to that effect. It is also, as it were, the cement, which keeps the various members of the Mission together. Men and women are so apt to drift away from one another and lose sight of each other, if there is not continual fellowship. The Comforter affords this fellowship and binds the members together. Sever this band and we will fall away from one another, as the leaves of a tree fall off during Autumn. The leaves will then be blown hither and thither and will finally be covered up with mud and sand never to be seen or heard of again The wickedness of the world is so great today, that God's children will be hidden from one another. It is one of Satan's last moves to do away with that essential fellowship. ${ }^{47}$

The periodicals printed letters from readers from all over the world, thereby designating a sense of belonging to a worldwide community of believers.

The editors frequently asked readers to pray for the authors of the published letters. First person plural pronouns like "our" and "we," were almost always used in the articles and editorials, thereby designating a sense of community to the reader. This was due to the fact that multiple people were involved in the production of the paper, and all were given credit, yet it had the effect of extending membership to the readers.

47 "An Appeal for The Comforter," The Comforter, October 1922, 12. 
Finally, they frequently reproduced articles from other Pentecostal papers which served to advertise these papers and expand the growing network of Pentecostals. Excerpts from The Latter Rain Evangel, Word and Work, The Midnight Cry and The Pentecost provided a sense of belonging to a worldwide community, and served to introduce South African Pentecostals to their counterparts in America. Advertisements gave consumers access to other Pentecostal literature. Beginning in 1920s, the editors slowly began introducing advertisements for Pentecostal hymnbooks, tracts, spiritual literature, and Bibles. Mary Woodworth Etter was one of the first to have her books advertised in The Comforter. Etter was an American healing evangelist.

By October 1910 the group was able to print 3,000 copies of The Comforter for subscribers. ${ }^{48}$ By 1911 the mission decided that the publication was of such importance that they set up a separate fund and committee solely for the publication of The Comforter. They also announced increased circulation of the periodical in order to "reach the several points of the world where the paper has become a welcome visitor and a messenger of hope indeed!"49 By 1916 the group had purchased their very own cropper printing press and had made in the course of one year 336,000 impressions of Christian tracts at the cost of 32 pounds, 14 shillings, $3 d .{ }^{50}$ The purchase of the press was a sound financial

\footnotetext{
48 The Comforter, October 1910, 2.

49 The Comforter, May 31st 1911. (Addendum to the magazine)

50 The Comforter, June 1916. 6.
} 
investment, as the same amount of printing at a print shop would have cost them approximately 160 pounds. ${ }^{51}$ Pleased with the success of the tracts and periodicals, the group asked for financial help for the purchase of a cylinder printing press, which would cost 200 pounds. The Apostolic Faith Mission believed wholeheartedly in the primacy of the press. They did not charge for subscriptions or tracts but did ask that churches send in money for postage, and suggested that churches who regularly subscribed would consider sending in a monthly check of support to the Publication committee as well. When they were short on funds, they took money from the Executive council funds, which occasionally resulted in the workers' wages being cut short. ${ }^{52}$

Like The Apostolic Faith in the US, the Apostolic Faith Mission's The Comforter advertised new and "converted" papers inside its pages, so that their subscribers could also subscribe to these new papers as well. This had several advantages for the group and larger movement as a whole. First, reports of these new papers highlighted the worldwide growth of the movement and helped local subscribers to feel as though they were part of a larger movement and worldwide family of believers. In the initial issue, the group announced the publication of The Cloud of Witnesses to Pentecost in India, an Indian Pentecostal paper published by a group in Bombay, India, as well as a Dutch Pentecostal paper

\footnotetext{
51 The Comforter, June 1916. 6.

52 Ibid.
} 
entitled Spade Regen (Latter Rain) in Amsterdam. ${ }^{53}$ Reports of "converted" papers had a similar effect, by suggesting that the movement was authentic and growing because the Spirit of God was cleansing the church of corruption. Prominent conversions only offered more evidence to subscribers that they were on the "right" side of this movement. Second, by publishing the names and addresses of the missionaries in foreign lands, the publication contributed to the development of a worldwide web of Pentecostal contacts. Subscribers could easily write these missionaries letters of encouragement and anyone who wanted to enter the ministry could easily reach contacts who could offer them assistance. Publishing personal addresses created vulnerabilities as well. A note in a 1913 issue of Word and Witness shows that the post was a cutthroat arena for religious groups: "We are sorry to learn that some have been watching our columns in order to pick up names and addresses to which they have sent unsound unchristian literature. Professing to be angels of light, they have been doing the devil's work in deceiving unstable souls with their erroneous literature." 54

Within a matter of months news of the success of the South African mission was being published in multiple periodicals in the United States. The group used their ties with other Pentecostal papers to convey news of the mission in South Africa to interested readers, raise funding for the mission

\footnotetext{
${ }^{53}$ God's Latter Rain, Nov. 1908, 10.

${ }^{54}$ Word and Witness, Dec. 20th, 1913, 3.
} 
through solicited donations, and contribute to the growing global Pentecostal movement. The Pentecost, a publication out of Indianapolis, IN, where the group had originated, reprinted letters from John G. Lake, the Hezmalhalchs, and the Lehmans regularly. The group received a front page spread in the December 1908 issue. ${ }^{55}$ Readers of The Pentecost could send donations to the Apostolic Faith Mission in South Africa directly. After Clara Lum and Florence Crawford took the Apostolic Faith magazine to Portland, they continued to issue the paper and offered frequent reports from the South African mission. Most of the letters from Lake, Hezmalhalch, Sackett and Lehman focused on the large number of conversions and accounts of miraculous healing. In a letter published in The Pentecost, Lake asserted that "Johannesburg is unquestionably the greatest field for missionary work in the known world." ${ }^{56}$ Most of the workers that the Apostolic Faith Mission recruited were from the surrounding area, but some came after they heard of the need through the periodicals in the US. In January 1909, it was reported that there were at least "fifty workers spread throughout South Africa." Individuals could be licensed as ministers or evangelists through the Apostolic Faith Mission. Evangelists had the authority to preach, heal, consecrate children, bury the dead, baptize, and administer the Lord's Supper. Ministers could do the

\footnotetext{
55 The Pentecost, December 1908, 1.

56 The Pentecost, December 1908, 7.

57 The Pentecost, January 1909, 9.
} 
same and perform marriages. The licenses were signed by the President, Vice President, and Secretary.

A 'pneuma network' of Pentecostals was critical for the survival and growth of the Apostolic Faith Mission in South Africa. Thousands of autonomous evangelists, ministers, pastors, and laymen communicated through a vast network of transnational Pentecostal periodicals, dedicated to spreading the message and growing the movement. Built on the foundation of the American Holiness print circulars, this new Pentecostal network of believers was dedicated to advancing the fledgling movement around the world. The network provided missionaries and pastors with a tremendous audience and support system for their work. In return, missionaries and evangelists gave readers a sense that they were part of a world-wide, cosmopolitan, Spirit-led movement. The editors of The Comforter recognized this aspect of print culture as essential to the movement: "Unquestionably, there is in these latter days, a love and unity springing up among the Saints, all over the world, that is in itself a testimony most striking to what the Baptism of the Holy Ghost means, and this is intensely felt as Pentecostal correspondence is exchanged." 58 The bulk of these periodicals printed in the early twentieth century came from the Atlantic. The missions in the United States, Europe and Africa printed and distributed these papers en mass for no subscription fee. Typically, the missions would print them as donations

58 God's Latter Rain, November 1908, 10. 
allowed. The successful papers were engines of profit for their missions, serving as news, advertisement, and source of revenue.

Although the Pentecostal missionaries arrived in South Africa essentially as autonomous agents, working without the support of an American church or multinational mission organization, they identified as being part of the Apostolic Faith Mission/Movement in America from the beginning. They referred to themselves as the "Apostolic Faith Missionaries" and called their mission the Apostolic Faith Mission. ${ }^{59}$ The name not only indicated their ties with the American Pentecostal movement, but also to that of the early church. P.L. Le Roux (1865-1943) explained the choice of the name at a November 1916 ordination service, saying "We call ourselves the Apostolic Faith Mission, we expect the same power to rest upon us that rested on the early church, and we expect to do the same work." 60 They did not receive direct financial support from the American mission. While this made them particularly vulnerable to shortages of financial support, it also allowed them freedom from typical denominational regulation. The Pentecostal group was extremely wary of presenting themselves as just another church. They avoided referring to themselves as a church, and instead presented themselves as part of a movement: "This outpouring of the

59 The Forerunner of God's Latter Rain, [booklet], August 1908. Johannesburg, South Africa. Reprinted in Lake, John G., and Roberts Liardon. John G. Lake: The Complete Collection of His Life Teachings. (Tulsa, Okla: Albury Pub, 1999), 44-48.

60 "Ordination Service" The Comforter and Messenger of Hope, June 1916, 6. Apostolic Faith Mission Archives, Auckland Park Theological Seminary, Auckland Park, Johannesburg, South Africa. 
Spirit is not confined to any church or sect or people. In Johannesburg, we see persons of every denomination, of every religious creed, alike seeking God for a real and definite work of grace in their souls and all alike at the feet of Jesus receiving from Him the baptism of the Holy Ghost." 61 The group's perception of themselves as a movement instead of a church would allow them to attract a range of people disenchanted with the established churches, both Christians and non-Christians alike, but would also open them up to attack from mainline churches who viewed them as competition in the saturated mission landscape.

${ }^{61}$ The Forerunner of God's Latter Rain, 45. 


\section{CHAPTER 6: \\ THE UNLIMITED COMPANY: THE APOSTOLIC FAITH MISSION AS \\ EVANGELICAL BUSINESS, 1913 - 1928}

This chapter analyzes the second phase of the Apostolic Faith Mission in South Africa that runs from 1913 to 1930 . It traces the story first against the backdrop of South African political history of the period. Second, it chronicles the specific woes of the movement after the first successes beginning in 1908. These include ones of leadership, finances, and ideology. Third, it treats the way the movement, inspired by values from the Dutch Reformed Church (NKG), reshaped itself institutionally, specifically under the powerful Afrikaner leadership of men like Pieter Le Roux. Fourth, it analyzes the growing consideration of race in this period both for the dominant structure as well as for individual Pentecostals. Finally, it chronicles how issues of gender, race, and black consciousness led to actual schisms within Pentecostalism in South Africa.

One of the most thorough ecclesiastical histories of the Apostolic Faith Mission during these years was captured by Christiaan De Wet in his 1989 dissertation, The Apostolic Faith Mission in Africa: 1908-1980 A case study in Church Growth in a Segregated Society. ${ }^{1}$ De Wet examines the ecclesiastical history of the Apostolic Faith Mission, and was one of the first to trace some of the social factors responsible for the rise of the AFM in Africa during the twentieth century. De Wet's focus is more ecclesiastical, but he provided the first insights

\footnotetext{
${ }^{1}$ De Wet, The Apostolic Faith Mission in Africa, 1908-1980 A Case Study in Church Growth in a Segregated Society. (Ph.D. Diss., University of Cape Town, 1989).
} 
into the mission's history, and his work remains foundational for any study on the mission. De Wet correctly locates some of the major factors for the evangelical success of the Apostolic Faith Mission in Africa at large. The Apostolic Faith Mission's official history, written by the current AFM President Isak Schalk Burger, is surprisingly thorough as well, and offers a detailed institutional history of the mission. ${ }^{2}$ De Wet and Burger are some of the few scholars who have utilized the sources at the Apostolic Faith Mission archives, including the mission's periodicals. One of the foremost scholars on global Pentecostalism, Allan Anderson has also written extensively about the South African Zionist churches, African Pentecostals, and the rise of African Initiated Churches. ${ }^{3}$ Other scholars who broach the topic tangentially in their works are Bengt Sundkler and David Maxwell. ${ }^{4}$ While these scholars have together provided the foundations for

\footnotetext{
${ }^{2}$ Isak Burger and Marius Nel. The Fire Falls in Africa: A History of the Apostolic Faith Mission in South Africa: A Centennial Edition 1908-2008. (Vereniging: Christian Art Publishers, 2008).

${ }^{3}$ Some of Anderson's classic work on South African Pentecostalism include Allan Anderson, Moya: The Holy Spirit in an African Context. (Pretoria: University of South Africa, 1991); Zion and Pentecost: The Spirituality and Experience of Pentecostal and Zionist/Apostolic Churches in South Africa. (Pretoria: University of South Africa, 2000); Bazalwane: African Pentecostals in South Africa. (Pretoria: University of South Africa, 1992); Umoya: Pneumatology from an African Perspective. (Pretoria: Unisa, 1990); African Reformation: African Initiated Christianity in the 20th Century. (Trenton, NJ: Africa World Press, 2001); Allan Anderson and Samuel Otwang, Tumelo: The Faith of African Pentecostals in South Africa. (Pretoria: University of South Africa, 1993); Allan Anderson, "Exorcism and Conversion to African Pentecostalism". Exchange: Bulletin De Littérature Des Églises Du Tiers Monde. 35, no. 1 (2006): 116-133; and Allan Anderson, 1999. "The Lekganyanes and Prophecy in the Zion Christian Church". Journal of Religion in Africa. 29, no. 3: 285-312.
}

For more on Anderson's general works on Pentecostal studies and global Pentecostalism see: Allan Anderson, Spreading Fires: The Missionary Nature of Early Pentecostalism. (Maryknoll, N.Y.: Orbis Books, 2007); To the Ends of the Earth Pentecostalism and the Transformation of World Christianity. (New York: Oxford University Press, 2013); Studying Global Pentecostalism: Theories and Methods. (Berkeley: University of California Press, 2010); and An Introduction to Pentecostalism: Global Charismatic Christianity. (Cambridge, U.K.: Cambridge University Press, 2004).

${ }^{4}$ Although his primary focus is Zimbabwe, David Maxwell's work is essential reading for those 
understanding the history of the AFM in South Africa, the periodicals that the mission produced during its history have only received glossing attention. Yet these periodicals are rich with the writings of the early members of the movement, and they indicate that South African Pentecostals saw themselves as part of a larger cosmopolitan and global community than their other sources would suggest. The first two decades of the young Union of South Africa saw the depression, war, and the hardening of racial segregation in society with the rise of Afrikaner Nationalism. The Union of South Africa was formed in 1910 through the uniting of the four territories (Natal, the Cape, Orange Free State, and Transvaal) under the British Commonwealth. The preceding South African Act of 1909 stripped black Africans of their political rights in three of the country's four states, leaving only the Cape Coloured population with some voting rights. ${ }^{5}$ The biggest concerns pressing on the new union were questions of land and labor. Segregation became encoded in a series of laws passed by parliament that served to segregate blacks and compel them into a wage economy. The Native Lands act of 1913 created "reserves" for black Africans which served as migrant labor pools for the mines and prohibited them from purchasing land. The 1923

\footnotetext{
interested in the transnational movement of Pentecostalism, particularly in Southern Africa. See: David Maxwell, African Gifts of the Spirit: Pentecostalism \& the Rise of a Zimbabwean Transnational Religious Movement. (Oxford: James Currey, 20. Bengt Sundkler's work on Zionist churches is foundational: Bengt Sundkler, Bantu Prophets in South Africa. (London: Oxford University Press, 1961); and Zulu Zion and Some Swazi Zionists. (London: Oxford University Press, 1976).

${ }^{5}$ Davenport and Saunders, South Africa: A Modern History; Elinor Sisulu, Walter \& Albertina Sisulu: In Our Lifetime. (Claremont, South Africa: David Philip, 2003), 32; Bernard Porter, The Lion's Share: A History of British Imperialism, 1850-2011. (Harlow, England: Pearson, 2012), 176-179; For more on the formation of the Union and the constitution see: Heinz Klug, The Constitution of South Africa: A Contextual Analysis. (Oxford: Hart Publishing, 2010).
} 
Native Urban Areas Act was designed to limit African immigration to urban areas and further restrict African property rights. ${ }^{6}$ Non-white groups organized political associations in response to their disenfranchisement, including the South African Native National Congress (SANNC) in $1912^{7}$ and the South African Indian Congress (SAIC) in 1924.

In the aftermath of the formation of the Union, two nationalist parties emerged: the National Party, formed by Afrikaner nationalists dedicated to improving the condition of poor white Afrikaners; and the African National Congress, formed by black South Africans in 1912 dedicated to asserting the political authority of blacks. World War I broke out in 1914 and subsequently ripped open old wounds. The English-speaking whites and elite blacks were firmly on the side of the British during the war, while other groups, particularly poor Afrikaners, tended to be on the side of the Germans, as they were still reeling from the loss of the South African War and its messy end. ${ }^{8}$ Poor black laborers were also displeased with the way the British had utterly abandoned them after the South African War, and thus were resistant to support them during WWI. One miner expressed these sentiments in a letter home, saying "God be

\footnotetext{
${ }^{6}$ William Beinart, and Saul Dubow, Segregation and Apartheid in Twentieth-Century South Africa. (London: Routledge, 1995), 3-4; Davenport and Saunders, South Africa: A Modern History, 551.

${ }^{7}$ Renamed the African National Congress (ANC) in 1924.

${ }^{8}$ The war itself was a huge loss, but the continued news of the actions of the British during the War - in particular the stories of concentration camp survivors - fed increasing resentment amongst Boers.
} 
with Germany and clear out all the Englishmen on Earth. Indeed If the German came out in South Africa we shall be glad if we can help them too."”

During these years of war the AFM struggled to maintain its initial gains. In early 1913, the mission faced many serious troubles stemming from the decentralized and democratic nature of the Pentecostal movement as a whole. Frustrations over leadership, management, theology, and church practice divided the members and had resulted in many resignations of the mission's early leaders. At least seven major leaders in the early movement resigned between 1909 and 1913, and some took other AFM members with them. ${ }^{10}$ The minutes of the executive council illuminate one source of the frustration with the mission:

Letter read from Bro. Schneiderman stating his reasons for having dissociated himself from the work. He pointed out that a great deal of very sad exaggerations in cases of healing had been made, that messages had been given not by God, etc. and that the name of God was dishonoured thereby. The Council discussed the letter at some length. It was felt that there was only too much truth in the letter. Resolved: in future to use the utmost caution and to do all in our power with the help of God to eliminate from the work whatever was not of God, and to admit to the public that many mistakes had been made, even if such a confession cost humiliation. ${ }^{11}$

\footnotetext{
${ }^{9}$ A. M. Grundlingh, Fighting Their Own War: South African Blacks and the First World War. (Johannesburg: Ravan Press, 1987). 16.

${ }^{10}$ Schneiderman and Kerr resigned in January 1909, J. O. Lehman resigned in June 1909, and W. Elliot resigned in August 1909. The Turenys resigned in 1910. J.A. Morwane resigned as an overseer in 1910 with fourteen of his followers. Eight members of the Vrededorp Committee resigned in 1911 over the Peace Hall disagreement. AFM Executive Council Minutes, January $7^{\text {th }}$, 1909,19 ; January $22^{\text {nd }}, 1909,22-23$; June $25^{\text {th }}, 1909,25$; August $13^{\text {th }}, 1909,50$; February $25^{\text {th }}$, 1910, 51; November 11 $1^{\text {th }}, 1910,67-68$; March $16^{\text {th }}, 1911$. Apostolic Faith Mission Archives, Auckland Park Theological Seminary, Auckland Park, Johannesburg, South Africa.
}

${ }^{11}$ AFM Executive Council Minutes. January 22nd, 1909. 23. Apostolic Faith Mission Archives. 
Another member resigned over the issue of holding "special meetings for only those who have had the baptism of the Holy Ghost." 12 These incidents reflected a common concern within the growing Pentecostal movement as a whole. A lack of centralized authority left the movement vulnerable to divisions over theological teachings and notions of acceptable practice. In these early years most mission workers were untrained and lacked schooling, and there was a lack of oversight and basic management.

Much of the frustration implicitly implicated Lake, as he had proven himself to be a gifted evangelist but a poor manager of the mission's finances. In the early years the mission had depended on donations from abroad. Lake had been charged with managing the finances, but like William Seymour, had failed to keep any records of income and expenditures. In 1913 the mission's finances were in a shambles, and they were some $£ 300$ in debt. ${ }^{13}$ This was due to a number of factors including high rents and the fact that most of their financial support came from assemblies comprised of poor whites and blacks. More critically however, Lake was accused of being at best a terrible record keeper, and at worst, an embezzler of funds, as well as incurring mission expenditures of over $£ 350 .{ }^{14}$ In an October 1912 Conference Business Meeting, the council had decided to entrust Lake with all tithes, saying:

Resolved that Tithes should go to the local Treasurers where there are local Assemblies; That all Treasurers and certificated workers are

\footnotetext{
${ }^{12}$ AFM Executive Council Minutes. January 22nd, 1909. 23.

${ }^{13}$ AFM Executive Council Minutes. Nov. 10th, 1913. 116.

${ }^{14}$ AFM Executive Council Minutes. Nov. 10th, 1913. 115.
} 
authorized to receive the tithes; That all tithes and offerings sent directly to Bro. Lake shall be regarded as being for himself or wheresoever the Lord may lead him to give it; and that, whereas it is customary for people to send offerings to Br. Lake specified as "for the work of the Lord", it shall be understood that such monies are to be used for himself, or as he sees fit. ${ }^{15}$

By November of 1913 the mission had paid back the debts, but had almost no money left to pay their workers monthly.

The lack of management and transparency led to infighting, which spread across the Atlantic through a barrage of accusatory and defensive letters. The sordid controversy played out in at least one American Pentecostal periodical, The Upper Room, published by Pentecostal pastors E.K. Fischer and Geo. B. Studd in Los Angeles. ${ }^{16}$ Hezmalhalch in particular explicitly blamed Lake, and he was joined in his accusations by no less than five other AFM members. The charges were that Lake has first, misappropriated funds; second, failed to keep promises to send money to native workers; third, exaggerated reports of the successes of the mission; and finally, that Lake "was ambitious to be The Great Chief of all the work, and of exercising the spirit of 'boss' ('a second Dowie,' one wrote)."17 Lake, Hezmalhalch, and other AFM pastors including at least two

\footnotetext{
15 "Minutes of Conference Business Meeting," AFM Executive Council Minutes. October 3rd, 1912. 98.

${ }^{16}$ The Upper Room periodical in many ways filled in for The Apostolic Faith beginning in the spring of 1909. The layout and content was heavily influenced by The Apostolic Faith, and the mission reported on worldwide missionary activity within the Pentecostal movement. Lake and Hezmalhalch visited the Upper Room Mission in October 1909 and developed a relationship with Elmer K. Fischer and Geo. B. Studd. Lake wrote extensively to the mission after he returned to South Africa, and in return the mission sent him significant donations gathered from the mission's members. The editors wrote "we feel God had linked us together - the Upper Room and the Apostolic Faith work in South Africa."

17 The Upper Room, November 1910, 2.
} 
Native Elders wrote many letters to the mission, which printed the accusations and defended Lake in The Upper Room. ${ }^{18}$ In his diary, Lake lamented, "my heart is grieved and sore on account of his [Hezmalhalch] treachery." ${ }^{19}$ Lake believed that Hezmalhalch was under the influence of other members and non-members who showed "terrific malice and envy" towards Lake's work in the country. ${ }^{20}$ The rift between the two founders caused a great deal of division within the group, and no doubt influenced Lake and Hezmalhalch's decisions to eventually permanently leave South Africa. ${ }^{21}$

While Lake's tenure in South Africa was evangelically successful, it was personally tragic. The death of Lake's wife left him with five children to care for alone. The infighting within the AFM didn't help his position in South Africa. Lake offered his official resignation to the executive council in a letter dated June 21, 1912, saying,

Herewith I tender my resignation as President of the A.F.M. The endeavour to maintain my home and family and conduct the affairs of the Mission at the same time is more than my body and brain can endure. I am in consequence poor at business and not at my best at my religious

\footnotetext{
18 The Upper Room lists Letwaba and Morwane.

19 John G. Lake Diary, December 21st, 1910. Apostolic Faith Mission Archives, Auckland Park Theological Seminary, Auckland Park, Johannesburg, South Africa.

20 John G. Lake Diary, December 21st, 1910.

${ }^{21}$ The Executive Council called Hezmalhalch to either "substantiate or retract the charges" made against Lake, which Hezmalhalch refused to do unless the other accusers Bowie, Gillies, Scurrah, Morwane, and Oliphant were present. When it became clear that these members would not appear and Hezmalhalch would not relent, the council reached the following decision: "The Council is therefore faced to end the present unsatisfactory State of Affairs by asking Br. Thos Hezmalhalch to withdraw from the position of Chairman of the Council and pastor of the Tabernacle until he hands in the required statement." AFM Executive Council Minutes. Nov. 11th, 1910.
} 
work. With tenderest love to every dear Bro. and Sister who have stood so loyally with me in the past. ${ }^{22}$

The Executive Council rejected Lake's resignation, declining to address it until the mission's General Conference in November. ${ }^{23}$

Lake departed the mission suddenly for the United States on February 19th, 1913. He left a letter for the executive council explaining that his health had taken a turn for the worse after a baptismal service in Cape Town that left him unable to continue field work. Yet he also suggested that his departure was not solely medical-related:

I am not idle in behalf of Africa, but am steadily working out on broad lines, and this is what I want you to lay before the brethren at the council meeting. That I am determined to establish an American Headquarters of the Apostolic Faith Mission of South Africa, and begin an evangelizing campaign, with the establishing of Branches just like we did in Africa...The only way we will ever achieve a satisfactory assistance in Africa is when we have a definite body of assemblies here who are definitely pledged in a bond of co-operation with us over there. ${ }^{24}$

He requested a certificate from the executive council that he might act on the mission's behalf in the U.S. ${ }^{25}$ Although Lake did not completely rule out a return to the mission, he advised that the council "make permanent arrangements for your work in Africa, just leaving me out of your consideration, and if God lets me return, well, if not the work must go on."26 The executive council met on March

\footnotetext{
${ }^{22}$ AFM Executive Council Minutes. June 21st, 1912. 91.

${ }^{23}$ Ibid.

${ }^{24}$ Letter from John G. Lake to P.L. Le Roux. Apostolic Faith Mission Archives, Auckland Park Theological Seminary, Auckland Park, Johannesburg, South Africa.

${ }^{25}$ Letter from John G. Lake to P.L. Le Roux, discussed in Executive Council minutes, March 1st, 1913.

${ }^{26}$ Letter from John G. Lake to P.L. Le Roux, discussed in AFM Executive Council minutes, March
} 
1st, 1913 to discuss Lake's departure from the mission, and decided that they would send a certificate to Lake to work on behalf of the mission in America. ${ }^{27}$ It took several months before the executive council met again to determine the future course of the mission. As Lake had not submitted a formal letter of resignation but had stated that he desired that they continue on without him, the group decided to hold new elections. P.L. Le Roux was nominated and elected by a vote count of 70 to 7 .

Pieter Louis Le Roux's (1865-1943) tenure as the President of the AFM ushered in a period of transition and institutionalization that stabilized the mission. Le Roux's religious upbringing first in the Dutch Reformed Church and then in the Zion Christian Church would have an indelible effect on his leadership in the Apostolic Faith Mission. Le Roux was born to working class farmers in the Western Cape at Wellington. From an early age, Le Roux was influenced by the teachings of Andrew Murray and the revivalist atmosphere at the time. "As a student he sat at the feet of the late Dr. Andrew Murray, and he certainly was one of the greatest admirers of the man of God" wrote D. J. Du Plessis, in an obituary for Le Roux. ${ }^{28}$ Le Roux married D.A. van der Merwe in 1886, but she died soon afterward during the birth of their first child. Eventually Le Roux was convinced by Andrew Murray that he should join the ministry of the Dutch Reformed Church

\footnotetext{
1st, 1913.

${ }^{27}$ AFM Executive Council Minutes, March 1st, 1913. 100.

${ }^{28}$ Die Trooster, July-August, 1943. 3.
} 
and work as a missionary in Wakkerstroom in the Eastern Transvaal (now Mpumalanga). Le Roux left Wellington on August 3rd, $1890 .{ }^{29}$ He arrived to learn Zulu and work at the Gordon Mission on November 1st, 1890. ${ }^{30}$ Le Roux became the first DRC missionary to native South Africans in the Eastern Transvaal. ${ }^{31}$ At this time revival broke out at the DRC church in Greytown, and the congregation asked Le Roux to stay and minister to the black workers. W.F. Dugmore, a later Mission Superintendent in the AFM, described Le Roux's involvement during the revival at Greytown: "As the outcome of a great revival among the Dutch Farmers, some of them had been preaching to the natives, and brother Le Roux was used to establish that work. There he saw the power of God manifested in a remarkable way. At times the whole congregation would be on their faces, praying and weeping their way to God." ${ }^{32} \mathrm{He}$ stayed for two years.

Like many of the first generation of Pentecostals, Le Roux was initially drawn to the movement due to its ties with divine healing practices. In 1893 Le Roux returned to Wakkerstroom, married Adriana Josina van Rooyen (18691956), and was ordained as a missionary by Andrew Murray. At this point Le Roux reestablished contact with a former acquaintance named Johannes Buchler in Johannesburg. Buchler practiced spiritual healing and gave Le Roux copies of Leaves of Healing, a US weekly periodical published by John Alexander Dowie.

\footnotetext{
${ }^{29}$ Diary of P.L. Le Roux, 1. Apostolic Faith Mission Archives, Auckland Park Theological Seminary, Auckland Park, Johannesburg, South Africa.

${ }^{30} \mathrm{lbid}$.

31 The Comforter, October 1913. 12.

32 W.F. Dugmore, "The Native Work," The Comforter, 1913. 12.
} 
Influenced by the periodical and Buchler, Le Roux became convinced of the veracity of spiritual healing, which caused division within the local mission, whose leaders did not want Le Roux to preach or teach on the subject. Le Roux eventually resigned in 1900, but stayed with the church through the end of the war, at their request. The AFM claimed that over 2,000 had joined the church in the Transvaal and Zululand by the time Le Roux left in $1900 .{ }^{33}$ In March 1903 Le Roux officially resigned as a missionary and member of the DRC and left to join the Zionist Church of Alexander Dowie, taking with him approximately three quarters of the black congregants. ${ }^{34}$ In May 1904 the South African Overseer of Dowie's Christian Catholic Church in Zion, Daniel Bryant, visited the mission and held open air baptismal services at the Wakkerstroom River. On the 11th and 12th Bryant baptized 141 believers including Pieter and Adriana Le Roux. ${ }^{35}$ On July 31st, 1904 Pieter Le Roux was ordained as an elder in the Christian Catholic Church in Zion, and Adriana was ordained as an evangelist. ${ }^{36}$ When Bryant left for the United States in 1906, he left his congregation in the care of the Le Rouxs. Two years later, this congregation would join the AFM.

\footnotetext{
33 The Comforter, October 1913. 12.

34 Ibid.

${ }^{35}$ As recorded in a report by Bryant published in Leaves of Healing, Vol 15, No. 13, July 16th, 1904. 411-412.

${ }^{36}$ Letter from Daniel Bryant, Overseer in the Christian Catholic Church in South Africa to the Headquarters of the Christian Catholic Church of South Africa, dated August 5th, 1904 certifying "Adriana Josina le Roux" as "a Minister of the Gospel in the Christian Catholic Church in Zion" as of July 31st, 1904. Apostolic Faith Mission Archives, Auckland Park Theological Seminary, Auckland Park, Johannesburg, South Africa.
} 
P.L. Le Roux brought about a managerial revolution in the AFM that would chart its course for years to come. The official AFM history presents Le Roux as a "peacemaker" and contends that his "leadership brought calmness, unity, consolidation, and security" to the mission. ${ }^{37}$ Indeed, in his positions as both President of the AFM and Superintendent of the Native Missions work, Le Roux implemented measures that stabilized the mission's finances, consolidated control of the mission in the hands of the executive council, and increased the production of The Comforter. It was under Le Roux's leadership that the group softened their anti-institutional stance and the mission evolved into an assembly. His policies were a quantitative success. By 1918, ten years after the first group had set foot on the continent, the AFM boasted a membership of 5,000 whites and 13,000 non-whites. ${ }^{38}$ Yet consolidation came at a price.

P.L. Le Roux's tenure as President of the AFM brought standardization to the discourse and ecclesiastical structure of the Apostolic Faith Mission. Immediately upon the election of Le Roux, the Executive Council intensified a trend towards organization. The AFM structure was based on committees, assemblies, and conferences. The council elected an Executive Council of the Publication Committee, with P.L. Le Roux as Editor, Scott Moffat, Welsh and Dugmore. ${ }^{39}$ This approach to establishing committees for managerial oversight

\footnotetext{
${ }^{37}$ Isak Burger and Marius Nel. The Fire Falls in Africa: A History of the Apostolic Faith Mission in South Africa: A Centennial Edition 1908-2008. (Vereniging: Christian Art Publishers, 2008), 93.

${ }^{38}$ AFM Executive Council Minutes, November 11th, 1918, 57.

${ }^{39}$ AFM Executive Council Minutes, November 11th, 1913. 123.
} 
was fundamental to Le Roux's leadership, and was a clear break from the prior laissez faire-approach of Lake and Hezmalhalch. It reflected the ecclesiastical structure of the Dutch Reformed Church and focused on white oversight at the top echelons of power but initially allowed broad oversight of the local assemblies almost entirely by native ministers. By 1919 the AFM controlled fourteen districts: 1) South Eastern Transvaal, 2) Witwatersrand and surroundings, 3) Waterberg and Pietersburg, 4) Northern Zoutpansburg, 5) Lydenburg, 6) Orange Free State, 7) Middelberg, 8) Transvaal West, 9) Gwanda, 10) Tsolo, 11) Harding and Umzimkulu, 12) Gazaland, 13) Basutoland, and 14) Gatooma. ${ }^{40} \mathrm{~A}$ list of "Ministers in the Native Work," posted in a 1919 issue of De Trooster, shows that most are natives, and some Africans served as overseers. ${ }^{41}$

As in Azusa, the first generation of Pentecostals tended to bristle at the idea of officially organizing. The decision to officially organize as a church caused rifts at Azusa and it appears that the American Pentecostals were against official recognition in South Africa as well. However the resistance to government recognition as a church led to many practical problems. Without government recognition, the mission and its workers were vulnerable. Moreover, it was financially destructive, since the properties were not owned by a legal association but rather were in the names of individuals. This problem caused internal fighting amongst the leadership of the mission and reached a crisis point in 1910 when

\footnotetext{
${ }^{40}$ De Trooster, March 1919. 9.

41 lbid.
} 
the Executive council decided to purchase a "Vredezaal" (Peace Hall) in the Vrededorp suburb of Johannesburg that had come up for a reduced price of $£ 200$. In order to do so the property had to be purchased under the names of Thomas Hezmalhalch, Jurgens Hendrik Greeff (the Vrededorp pastor) and Egbert Elias Brink ${ }^{42} \mathrm{~A}$ few months later, Brink, who had put up most of the funding, asked for the loan money back. The executive council could not pay back the money so they ended up having to transfer the Hall into Brink's name entirely, whereupon he would rent the hall to the mission for $£ 4$ per month until the AFM gained the funding to but it back. ${ }^{43}$ Brink and Greeff had a falling out in the spring of 1911 which ended with Brink organizing a coup de tat against Greeff by unilaterally firing him and padlocking the doors to the now-humorously named "peace" hall. The AFM attempted to regain the hall through legal channels but were unsuccessful due to their precarious legal standing as a non-recognized church. ${ }^{44}$

The decision by the Executive Council, led by Le Roux, to organize as an "unlimited company" instead of a church underscored the group's resistance to denominationalism. On August 2nd, 1913 the Executive Council decided to register as an "Unlimited Company" instead of a church. Thus members of the Apostolic Faith Mission were company members. It would remain registered as a

\footnotetext{
42 AFM Executive Council Minutes, June 2, 1910. 245.

${ }^{43}$ AFM Executive Council Minutes, October 14, 1910. 64.

${ }^{44}$ AFM Executive Council Minutes, March 16, 1911. 79; May 23, 1911, 82-83, and November 3, 1911, 84. For a more detailed discussion of the event see: Isak Burger and Marius Nel, The Fire Falls in Africa, 81-82.
} 
company for the next 48 years, only registering as an official church in 1961. Looking back in 1948, the editors of The Comforter-Trooster explained that "When they approached the Government Officials it was discovered that the only way of getting the desired recognition was to incorporate the Mission as an unlimited Company." ${ }^{" 5}$ Moffat and Dugmore brought the issue to the executive council committee for a vote, and it passed unanimously. Yet the choice to register as a company instead of a church left the mission with little power against the demands of the State. ${ }^{46}$ De Wet correctly notes that "It was the policy of the government that local black workers had to work under the supervision of white overseers in order to enjoy official recognition. Without official recognition it was of course impossible to acquire ground for church building and other important matters." ${ }^{\prime 7}$ This may indicate one reason why the leaders chose to tolerate an ideology of apartheid that seemed so at odds with the original Pentecostal message of "democracy in the Spirit."

Once the group obtained government recognition as an unlimited company, they implemented an aggressive mission policy to increase growth.

The AFM minutes record their concerns:

If we look ahead to see what the needs will be for the next 12 months we realize that a real forward policy must be adopted, not that the A.F.M. may be glorified but that the Lord may be glorified throughout the whole world. We are the Lord's rememberancers. Let us pray for the workers and their needs. How much so we really know of the needs of the workers on the outside. They tell us they are limited and unable to answer all the calls that

\footnotetext{
${ }^{45}$ Comforter-Trooster, May 1948, 3.

${ }^{46}$ De Wet, The Apostolic Faith Mission in Africa, 163.

47 lbid.
} 
come to them. The Macedonian cry is everywhere "Come over and help us." Finances are needed, but that is not the first essential. We want men $\&$ women who are willing to pay the price \& go out and spread this glorious Gospel. ${ }^{48}$

The workers - black and white, men and women - served as ministers and evangelists to communities throughout the country. At the November 1913 meeting there were 88 licensed workers.

The role of The Comforter/De Trooster during these years of transition was to stabilize the mission and unify its (predominantly white) readers. One of Le Roux's main priorities was to put new effort into the publishing of The Comforter and De Trooster, but he proved to be particularly ill-adept at managing a publication. Between 1910 and 1916 the mission only managed to produce eleven issues of The Comforter and three issues of De Trooster. World War I played a role in the disruption, as indicated by the fact that during the war years the mission only produced a single issue. ${ }^{49} \mathrm{He}$ did this through formalizing the content, focusing primarily on news related to the mission. A 1916 issue exemplifies this focus: The front page was devoted to an editorial concerning the need for a printing press, pages 2-6 dedicated to a detailed summary of the

\footnotetext{
${ }^{48}$ AFM Executive Council Minutes. November 10th, 1913. 116-117.

49 The only copy I was able to locate is the June 1916 issue. The October 1913 issue is listed as Volume 2, Number 1, and the 1916 issue is listed as Volume 2, Number 2, so they numerically line up. However, the publication committee was not particularly capable of consistently listing the issues, so one or more may have been published and not preserved. De Wet notes a January 1916 in his dissertation, which suggests there may be another issue. See: Christiaan Rudolph De Wet, The Apostolic Faith Mission in Africa, 1908-1980 A Case Study in Church Growth in a Segregated Society, 164. Between 1916 and 1921 there is only a single issue of De Trooster dated March 1919. The 1919 issue is not numbered. The next issue, another Trooster, is dated March 1921 and is numbered Vol. 1 No.1, suggesting that there were likely no other issues published in between. If there were other Troosters or Comforters published during these years, they were very few in number and have not survived.
} 
General Conference, the Young People's Union and news from the districts covered on page seven, and a section on the building fund on page nine. ${ }^{50}$

One if the most significant changes that Le Roux implemented during these years was a re-emphasis on publishing AFM literature. In order to accomplish this goal more efficiently, the mission invested in a printing press. ${ }^{51}$ The mission printed tracts and the periodicals, and offered them free of charge to all subscribers. In the June 1916 issue of The Comforter, the editors explained that they had acquired "a small cropper printing machine" with "type sufficient to set up about two and a half pages" and a staff of two devoted workers dedicated to running the printing office. ${ }^{52}$ The staff had managed to print 336,000 impressions of tracts and literature: "The Baptism in the Holy Spirit," 5,000; "Divine Healing," 5,000; “Christian Baptism," 5,000; Convention Report, 4,000; "Hard Questions for Seventh Dayists," 5,000; "De Doop des Geestes," [The Baptism of the Spirit] 5,000; Goddelijke Genezing," [Divine Healing] 5,000; "De Christelijke Doop," [Christian Baptism] 8,000; “Moeilijke Vragen Voor Sabbat Houders," [Tough Questions for Sabbath Holders] 5,000; Conferentie Verslag, [Conference Report] 4,000; “De Doop des Geestes,"[The Baptism of the Spirit] (second edition) 8,000." 53 The editors put the total cost for the printing at $£ 32$

\footnotetext{
50 The Comforter, June 1916.

51 "Printing Plant," The Comforter, June 1916, 1.

52 "Some Pertinent Questions Regarding the Printing Office Answered," The Comforter, June 1916. 6.

53 lbid.
} 
14s. $3 d .{ }^{54}$ Printing that amount of literature in Johannesburg would have previously cost the mission $£ 160 .{ }^{55}$ The money used to fund the printing operation was drawn from the Executive Council funds, which had put a drain on the finances available for workers. Consequently they asked that local assemblies begin contributing monthly contributions for the printing office. ${ }^{56}$

Funding was a constant problem for publication, as the mission was barely able to pay its workers, let alone print thousands of copies of a periodical and mail them. The editors made it clear in every issue that "The 'Comforter' is supported by the free will offerings of God's children, and is sent free to any address. Help us to circulate it by sending addresses of all those who would appreciate the paper." ${ }^{57}$ When the periodical returned after a long break between 1913 and 1916, the front page of the issue spoke to the importance of establishing a permanent press in order to publish the paper consistently. The editors of The Comforter laid the printing situation before the readers, determining that the issue size would be reduced in order to be able to afford to print more consistently. The Printing Committee also strongly suggested that "our Assemblies and workers everywhere will agree to take so many hundred copies each at every issue and pay for them. In this way funds will be regularly forthcoming, and the paper will be published every two months or at least every

\footnotetext{
54 Ibid.

55 Ibid.

56 lbid.

57 The Comforter, October 1913, 8.
} 
quarter." 58 This course of action appears to have worked, as the mission's publication became more consistent beginning in the 1920s.

The Comforter's content and format evolved during these years to reflect the growing institutionalization of the mission. The periodical went from a threecolumn news oriented format to that of a two-column format more typical of healing or mission serials. ${ }^{59}$ It shifted focus from reporting news of the movement to more of an emphasis on publishing theological articles, sermons, reports from General Conferences, and longer testimonials. Longer testimonials meant fewer testimonials overall, and the numbers decreased significantly. The initial papers tended to put news of the mission up front and center in the issues, but over time this changed and the front pages were reserved for sermons or editorials. By 1921 the "News and Notes" section in The Comforter was one page long out of a sixteen page paper, and buried on page $13 .{ }^{60}$ From the 1920 s onward most of the articles are attached to names, particularly those of the editors.

Initially, a laissez faire attitude towards ecclesiastical structure and an emphasis on saving souls instead of building a church had given the mission a democratic spirit that is evident in their early documents. When the Executive Council was first formed in May 1909, the group passed a resolution stating:

58 "Editorial," The Comforter, June 1916. 1.

59 The change in format occurred with Volume 2 Number 2, published in June 1916. The previous issue (Vol. 2, No. 1) had been published three years prior in October 1913. The 1913 issue was an anomaly itself, as it featured a picture of the central tabernacle on its front page.

60 "News and Notes," The Comforter, August 1921, 13. 
The Brethren present constitute themselves into a Council, which constitutes of all the workers in active service for the Master, who teach the Gospel of Jesus Christ according to the Word of God and maintain the same as set forth in the Apostolic Faith Mission. The workers shall retain full liberty in the Holy Ghost, independent of each other, each worker being acknowledged as the head of the work thus undertaken by him, with whom the other workers will co-operate if required. ${ }^{61}$

This loose organization and heavy mission-oriented approach gave a great deal of leeway to African ministers working out in the countryside, and likely played a role in attracting many African converts to the mission in its early days, as it allowed for an upward mobility for black ministers unavailable in other missions. The Comforter contained a report on the success of the African Pentecostals in Johannesburg in August 1911, indicating that native ministers were given a significant amount of trust towards evangelizing to their fellow Africans:

The Johannesburg native work continues to go forward with much vigour. The leader reports that from 600 to 1,000 natives attend the Sunday afternoon open air meeting on the Market Square, and that many get saved there. A baptismal service is conducted once a month, and each month there are a good number to be baptized. This demonstrates that the natives are quite capable to get their own people saved; their preaching is clear and strong in the power of God. ${ }^{62}$

However, the "full liberty in the Holy Ghost" afforded in the early years was not to last. Although the Apostolic Faith Mission relied on an extensive network of native pastors, ministers, and evangelists, the white leaders increasingly desired European oversight. Beginning in 1910 the white ministry of the Apostolic Faith Mission was carried out from the Central Tabernacle, while the ministry to all others was carried out through the "Native Council" which reported to the all-

\footnotetext{
${ }^{61}$ AFM Executive Council Minutes. May 27th, 1909. 34.

62 "Central Tabernacle Notes," The Comforter, July-August, 1911, 3.
} 
white Executive Council, which had final say on all ratifications. ${ }^{63}$ The Native Council was comprised of three European and three native members. ${ }^{64}$ John G. Lake, P.L. Le Roux, and T. Schwede were designated to be the European members and J.Morvane, Elias Letwaba \& A. Oliphant as the native overseers. ${ }^{65}$ Members that desired to become workers would apply with the Native Council, which upon approval would submit their name to the Executive Council for final approval. The term "workers" covered local preachers, elders, deacons, and overseers. Women were allowed to work as local preachers. ${ }^{66}$ In a 1919 issue of De Trooster, the mission listed the names of 114 native ministers, two of which were women, along with seven overseers, two of which were black. ${ }^{67}$ Additionally, the mission noted that the local preachers and deacons numbered over 400.

In many respects, racial tensions were present in the work at the mission from the beginning. After the initial revival at the Doornfontein Hall, which was comprised of mostly "coloured" or "black" participants, the group moved to the Central Tabernacle on Bree Street, which seems to have been comprised of mostly white participants. ${ }^{68}$ Burton makes reference to early congregational

\footnotetext{
${ }^{63}$ AFM Executive Council Minutes, May 6th, 1910. 54.

64 Ibid.

65 lbid.

66 lbid.

67 De Trooster, March 1919, 10.

${ }^{68}$ Lodewikus Johannes Erasmus, Theological Education in the Apostolic Faith Mission of South Africa. (PhD Dissertation, Pretoria: University of South Africa, 1997), 27.
} 
segregation in the Central Tabernacle, saying "For a time the coloured people sat on the one side, and the Europeans on the other. ${ }^{69 "}$ Part of separation was due to language barriers that persisted. Initially, J.O. Lehman held separate services twice a week in Zulu, "for convenience's sake." ${ }^{\text {"I }}$ In the first meeting of the trustees, Lake made reference to the discrepancy by emphasizing the necessity "of securing adequate accommodation for the holding of services in Doornfontein especially for the Coloured people." 71 Lehman commented on the racial tensions in a 1908 letter, stating that "We began our first continued meetings in the colored church, and notwithstanding the prejudice that exists with the white people against the natives, when God began to work the white people came in such crowds that the natives became timid and were crowded out."72 This issue of "timidity" was a recurring theme in the lamentations of Lake in particular. Lake felt constantly aggravated at the racial attitudes of the whites in South Africa. His relationship with Elias Letwaba (1870-1959), an African convert, and later pastor and evangelist in the AFM, exemplified the scorn he felt towards this behavior. Burton described the first meeting between the two men, saying:

Lake put his arm about the black man's neck and kissed him, calling him, 'My brother,' while many of the unconverted white men in the hall booed and hissed at him, shouting, 'Bah! Fancy kissing a black man! He may be your brother but he's not mine,' and similar expressions of disapproval and contempt. Lake turned on the crowd like a flash, and shouted, 'My friends, God has made of one blood all nations of men.' If you don't want to acknowledge them as your brothers, then you'll have the mortification of

\footnotetext{
${ }^{69}$ Burton, When God Makes a Pastor, 38.

70 lbid.

${ }^{71}$ AFM Executive Council Minutes. Sep. 17th, 19081.

72 Letter by J.O. Lehman reprinted in The Pentecost, August 1908, 7.
} 
going away into eternal woe, while you see many of these black folk going to eternal bliss....Then holding out his hand to Letwaba once more, he said, 'Brother, I'm glad to welcome you into our midst. The furore and hissing increased, and many shouted, 'Put out the black devils. Kick them into the street.' However Lake, with his hand still upon Letwaba's shoulder, said quite calmly, 'If you turn out these men, then you must turn me out too, for I will stand by my black brethren. ${ }^{73}$

This instance of racial solidarity was in keeping with Lake's character who wrote often on the issue. However, it was clearly too much for many of the Afrikaner AFM members, and they were unimpressed with Lake's desire for greater unity between the races. In November 1908, the trustees discussed the issue of baptism, and decided that "the baptism of Natives shall in future take place after the baptism of the White people." ${ }^{" 14}$ In July 1909 the executive council minute notes read "In future the baptism of whites, coloured \& natives shall be separate." ${ }^{\prime 5}$

The move toward greater organization and institutionalization ensured the growing centralized power of the Executive Committee and white European control of the mission. While Le Roux held many good relations with AFM native pastors, he nonetheless allowed segregation in the AFM hierarchy. Over the years, the executive council commented on a number of issues pertaining to racial segregation within the AFM. In a 1921 issue of The Comforter, the AFM Secretary D. Bosman reported on the year's General Annual Workers'

\footnotetext{
${ }^{73}$ Burton, When God Makes a Pastor, 51.

${ }^{74}$ AFM Executive Council Minutes, November 6th, 1908. 10.

${ }^{75}$ AFM Executive Council Minutes, July 30th, 1909. 39.
} 
Conference. He recounted one day that was devoted entirely to the subject of relations between whites and blacks:

The President, who is also the Superintendent of the Native Work in general, said the missionary among the native people, must of, necessity be more intimate with the native than the ordinary man, and he should be prepared to shake hands with them anywhere. This of course, is not expected of everybody, On the other hand, we had not to despise the native, because he is a coloured man, for it. "Is our duty to preach the gospel to all who know nor the gospel, and if we do not wish to associate with the native, how can we bring the gospel to him? As for social intercourse, there existed no such teaching of social equality as far as he knew. It was then decided that European Overseers, and Workers in charge of the Native work, should teach the native never to be the first to offer his hand to a white person, or to approach them first in public places, but to wait until the white man made the first advance. ${ }^{76}$

That this discussion took up an entire day suggests that there was still some disagreement within the mission over racial egalitarianism, but ultimately the social pressures of the day won out. Scholars are divided on the racial inclusiveness of the Apostolic Faith Mission. Most suggest that the leaders were at best, people who accepted segregation out of a pragmatic attempt to appease the Afrikaner segment of the mission, and at worst, proponents of racial segregation and inequality. ${ }^{77}$ The reality was more complex, and changed over time.

The minutes from the Native Council and the Executive Council reveal frequent tensions between the two parties. One of the first areas of disagreement

\footnotetext{
76 "Report of the General Annual Workers' Conference," The Comforter, August 1921, 2.

77 Often this is characterized as economic competition between poor whites and blacks. See: Matthew S. Clark, "Two Contrasting Models of Missions in South Africa: The Apostolic Faith Mission and the Assemblies of God," Asian Journal of Pentecostal Studies vol. 8, no. 1 (2005): 144.
} 
was over the issuance of certificates. The Executive Council of the Apostolic Faith Mission issued various certificates to ministers that showed they were authorized by the mission to perform certain services. Worker's certificates authorized the holder to the right to "preach the Gospel and pray for the sick and to lay on hands." ${ }^{\prime 7}$ Evangelist certificates allowed all of the rights of the Worker's certificate but also allowed the holder to administer the sacraments. ${ }^{79}$ Elder certificates were reserved for pastors or leaders of assemblies. ${ }^{80}$ Problems arose when the Executive Council required black overseers to obtain prior approval for certificates before they could issue them to anyone.

Black leaders within the Apostolic Faith Mission had varying responses to the increasing consolidation of white executive control of the mission. Some like J.A. Morwane simply left and took their members with them. ${ }^{81}$ Some sought to keep under the umbrella of the AFM name but retain independence over their own black assemblies. ${ }^{82}$ And finally, some like Elias Letwaba chose to stay within the AFM, working their way to positions of prominence. Some of the leading African leaders in the Apostolic Faith Mission during this period included Elias

\footnotetext{
78 "Ordination Service," The Comforter, June 1916. 5.

79 lbid.

80 "Assemblies" was the term the AFM used for "churches." They distanced themselves from the term "church" due to their restorationist stance. They did not believe they were supposed to be a new sect or church but movement within pre-established churches to reform the universal church.

${ }^{81}$ AFM Executive Council Minutes, November 11 $1^{\text {th }}, 1910.66$.

82 The Zion Apostolic Church was in constant struggle with the AFM, as they adopted much of the Pentecostal theology but desired to keep the name "Zion" in their name. They also desired to carry on their own work independently from the oversight of the AFM Executive Council.
} 
Letwaba, Elias Mahlangu, and A. Oliphant. Of these, Elias Letwaba left the most detailed record behind, and remains an intriguing figure in the history of the AFM.

Letwaba was one of many black AFM members who chose to work within the institution despite the increasingly paternalistic attitudes of the Executive Council. His life was chronicled in the 1934 publication "When God Makes a Pastor," by W.F.P. Burton, a fellow Pentecostal missionary. ${ }^{83}$ Letwaba experienced an atypical upbringing, as his parents were Christian Ndebele people living in the Transvaal region who spoke Afrikaans in the home instead of their native language Sindebele. ${ }^{84}$ The Letwaba's also did not allow Elias to participate in the traditional rites of passage of their tribe, which caused the other members to view the family with much "reproach and derision." ${ }^{85}$ Burton claims that Letwaba's mother had a vision of her son's future while she was pregnant, saying:

Six months before Letwaba's birth, as his mother was busy grinding coffee beans, and only occupied with very mundane thoughts, she was suddenly surprised by a vision. It was broad daylight, and the afternoon sun was streaming in, but all at once she was amazed to see a Man in white standing before her. She stopped her grinding, and looked up wonderingly into His face, when He said, 'You will shortly have a strong baby boy. He is to be a messenger for Me, to carry My gospel message to many places. He will suffer much persecution and weariness, but I will be with him and protect him until his death, making him a means of blessing to thousands and an instrument in My hands for establishing many Christian churches.' She was amazed, and scarcely knew what to say or do, but the heavenly Visitant disappeared as suddenly as He had come, leaving the black

\footnotetext{
${ }^{83}$ Burton was a prolific writer and went on to found Pentecostal missions in the Belgium Congo.

${ }^{84}$ Burton, When God Makes a Pastor, 10.

${ }^{85}$ Burton, When God Makes a Pastor, 12.
} 
woman cowering on her knees, and wondering at what had been shown her. ${ }^{86}$

By echoing the biblical annunciation accounts of Mary, mother of Christ, and Zechariah, father of John the Baptist, Letwaba's birth story fit well within a developing Pentecostal oral and testimonial theology. The family's story is a familiar one, for as David Maxwell has pointed out, "flight into the sanctuary of the Pentecostal community is often just the first stage of a conversion story." ${ }^{87}$ Nonetheless, Letwaba frequently faced opposition while preaching, especially to mixed-race audiences, as Burton describes in the following incident:

...when the inhabitants heard that a black man was actually preaching with a band of white folk, in the open air, they gathered a mob, and rushed at the preachers, stoning and kicking Letwaba, shrieking at him, "You black devil! What right have you to come preaching at respectable white people, as though we were sinners like you!" However a few white ladies were present, and they managed to get between the mob to the poor native preacher who had been knocked down, and offered him some protection. ${ }^{88}$

Burton described several similar incidents, all of which involve Letwaba being attacked by mobs, often only to be saved by whites. Letwaba's experience in the AFM exposes many of the difficulties that black ministers faced during this period. Burton describes Letwaba as being highly successful because he "adopted tones of deepest humility and respect" while preaching. ${ }^{89}$

\footnotetext{
${ }^{86}$ Burton, When God Makes a Pastor, 10.

87 David Maxwell, "The Durwall of Faith: Pentecostal Spirituality in Neo-Liberal Zimbabwe," in Brock, Peggy. Indigenous Peoples and Religious Change. (Leiden: Brill, 2005), 184.

${ }^{88}$ Burton, When God Makes a Pastor, 60.

${ }^{89}$ Burton, When God Makes a Pastor, 60.
} 
Letwaba epitomized the middle ground position that educated native workers served in the evangelization of South Africa. ${ }^{90}$ Letwaba was the most educated of the black overseers, as he received a German seminary education at the Berlin Lutheran Mission ${ }^{91}$ and he could speak and read in many languages, including Sindebele, Afrikaans, English, German, Zulu, Sesotho, Tonga and Xhosa. ${ }^{92}$ His multilingual capabilities made him invaluable in the mission field. Additionally, as an educated, multilingual native African, Letwaba was able to access the worldwide network of Pentecostals and lend a nonEuropean voice to the growing movement. The Upper Room Mission in Los Angeles published many of his letters in their periodical from the start, and Americans sent donations to him directly to fund his work in South Africa. He was one of very few black ministers to have articles, letters, and reports published in The Comforter.

The political realities of increasing racial segregation challenged the Pentecostals' dedication to the "democracy of the spirit" within the mission. Under Le Roux's leadership, the concept of the "democracy of the Spirit" was renegotiated to fall in line with the growing Afrikaner Nationalist political ideology of "separate but equal," ultimately resulting in what amounted to a "segregation of

\footnotetext{
${ }^{90}$ For more on native missionaries see: Lamin O. Sanneh, Translating the Message: The Missionary Impact on Culture. (Maryknoll, N.Y.: Orbis Books, 1989); Paul Stuart Landau, The Realm of the Word: Language, Gender, and Christianity in a Southern African Kingdom. (Portsmouth, NH: Heinemann, 1995); and Edward E. Andrews, Native Apostles: Black and Indian Missionaries in the British Atlantic World. (Cambridge, Mass: Harvard University Press, 2013).

91 "Among the Mission Fields of South Africa," The Latter Rain Evangel, September 1928. 16.

92 De Wet, The Apostolic Faith Mission in Africa, 1908-1980, 70.
} 
the Spirit" within the Apostolic Faith Mission. Le Roux instituted an ecclesiastical structure that copied that of the Dutch Reformed Church, whereby power was consolidated in the white-led Central Mission with other "daughter" assemblies formed along racial or ethnic lines. ${ }^{93}$ Tensions erupted into disruptions and ultimately, schism.

Two groups in this period challenged the increasing institutionalization of the Apostolic Faith Mission, and illuminate the divide between the leadership and some members of the mission. Both challenges resulted in schisms that rocked the mission. The first major challenge came from black leaders, and ended in a drawn out schism that saw several rising black leaders break away from the AFM during the 1910 s to form their own churches or join the growing Zionist churches. Some black ministers within the AFM publicly resisted the creeping paternalism and institutionalization of the Executive Council. A.P. Oliphant was another native supervisor in the AFM who unlike Letwaba aggressively challenged the mission's white leadership. In a letter to the Executive Council, Elias Mahlangu accused Oliphant of a variety of charges including printing and issuing his own certificates and stating publicly that "...he has nothing to do with the white people except Bro. Lake."94 The major offense lay with Oliphant's decision "sign and issue certificates himself," instead of getting them from the executive council. ${ }^{95}$ On

\footnotetext{
${ }^{93}$ De Wet, The Apostolic Faith Mission in Africa, 1908-1980, 128.

94 AFM Executive Council Minutes, February 2nd, 1915. 7.

${ }^{95}$ AFM Executive Council Minutes, February 2nd, 1915. 7. The procedure that was set up was that Overseers were supposed to petition the council for certificates, which the council would decide on and send if approved. By issuing certificates himself Oliphant was essentially
} 
February 2nd, 1915 the executive council called Oliphant to a special executive council meeting where he apologized for issuing the certificates, but explained that his petitions to the council for certificates frequently went unanswered for months. Furthermore, in a statement that illuminates the degree of institutionalization that was occurring under Le Roux's leadership, Oliphant asserted that "during Bro. Lake's time no strict rule was adhered to," and when Oliphant asked for certificates Lake would send "a number" to him, "some

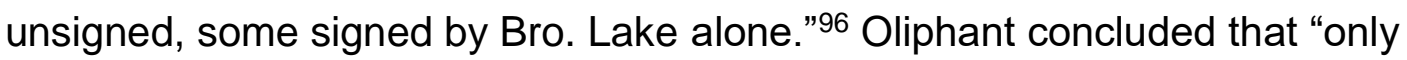
since Bro. Lake's departure has some strictness been exercised with certificates." ${ }^{\text {97 }} \mathrm{He}$ also repudiated the charge that he was not subject to the Europeans. ${ }^{98}$

As a result the Executive Council met and without any counsel from the black ministers passed a series of amendments to the resolutions passed previously in the Native Workers' Conference in 1910. The minutes read:

(a) That in future no Elder of Evangelist shall be ordained or expelled by Native Overseers except in open Conference, and in the presence and with the approval of the European Supt. Of the Native Work or his duly appointed representatives.

(b) That no Deacon or Local Preacher shall be ordained by Overseers or Elders without first obtaining the consent of the European Superintendent. The following resolutions moved by Bro. Dugmore seconded by Bro. Moffat are also adopted.

(1) That no minister or worker shall be received by an Overseer or Elder except with the consent of the Overseer or Elder under whom he has been

\footnotetext{
bypassing the white council.

${ }^{96}$ AFM Executive Council Minutes, February 2nd, 1915. 7.

97 Ibid.

98 lbid.
} 
working, and always subject to the approval of the European Superintendent.

(2) Whereas it is reported to the Council that certain certificates have been issued by Native Overseers such practice is declared to be illegal and highly reprehensible. ${ }^{99}$

Later that afternoon, the executive council met again; this time with the "native brethren" including Overseer A.P. Oliphant and Elders Elias Mahlangu, Johannes Mahlangu, and Nathaniel Teale. ${ }^{100}$ Le Roux notified the African members of the resolutions the Executive Council had passed in their absence and then the Executive Council ordered Oliphant to recall all of the certificates he had issued himself. At this point, the meeting took an unexpected turn. The minutes note, "Upon the question being raised of white clothing being worn and boots being taken off in services, Bro. Oliphant stated that he refused to remain for the discussion of these questions and left the meeting." 101 Oliphant's departure was seen as an affront to the executive council, who decided to send a letter reprimanding Oliphant "for the manner in which he left the meeting," and instructed him to attend the next meeting. Oliphant declined to appear, and furthermore refused to help in the "sending out of circulars re Native Conference." ${ }^{02}$ Oliphant continued battling the Executive Committee, even going

\footnotetext{
${ }^{99}$ AFM Executive Council Minutes, February 2nd, 1915. 8-9.

${ }^{100}$ AFM Executive Council Minutes, February 2nd, 1915. 9.

${ }^{101}$ AFM Executive Council Minutes, February 2nd, 1915. 10. The clothing questions have to do with the style typical of Zionist churches, which put much more emphasis on special religious clothing such as seen in Alexander Dowie's Christian Catholic Apostolic Church. The AFM believed such displays were unnecessary and vain.
}

102 AFM Executive Council Minutes, February 2nd, 1915. 12. 
so far as to call for a motion of separation from the AFM at the 1917 Native Workers' Conference. ${ }^{103}$ Oliphant eventually resigned in protest.

By the time the Native Conference met in December, it was evident that cracks were forming in the ranks of the mission. The Zion Apostolic Church workers refused to work anymore with the Apostolic Faith Mission workers. Le Roux offered " $\ldots$ a resolution to the effect that the AFM and ZAC agreed to work together and that when we hold conferences, both parties shall be represented." ${ }^{104}$ However, the meeting minutes record that "All Europeans present and all Natives of the AFM voted in favor. All Zion Natives voted against." 105 Four years later, after more infighting, a large block of black members left the AFM to join someone in starting the Zion Christian Church. The length to which the AFM adopted segregationist ideology became glaringly apparent in the July 1917 Workers' Conference. The assembly discussed the "question of natives and Coloureds attending the European services," which apparently "proved to be a very knotty question" as no resolution could be reached the first day. ${ }^{106}$ On the second day, after much debate, the assembly reached the following resolution:

That we do not teach or encourage social equality between Whites and Natives. We recognize that God is no respector of persons, but in every nation he that feareth Him and that worketh righteousness is acceptable to

\footnotetext{
${ }^{103}$ Minutes of the Native Workers Conference of the Apostolic Faith Mission, 1918. 43. As cited in Lodewikus Johannes Erasmus, Theological Education in the Apostolic Faith Mission of South Africa. (D.Th. Diss., Pretoria: University of South Africa, 1997), 30.

${ }^{104}$ AFM Native Workers Conference Minutes, December 8, 1915.

105 lbid.

${ }^{106}$ AFM Executive Council and Workers Conference Minutes, Book 1, July 6th, 1917. 134.
} 
Him. We therefore preach the Gospel equally to all peoples, making no distinctions. We wish it to be generally known that our White, Coloured, and Native peoples have their separate places of worship, where the Sacraments are administered to them. We further recommend that in the Central Tabernacle, and other assemblies if desirable, certain seats be reserved for coloured persons who may attend there. Further, that in the case of certain worthy coloured families attending at the Central Tabernacle the matter be left in the hands of the Spiritual Committee. ${ }^{107}$ P.L. Le Roux dedication to "unity" over "equality" in the AFM left many blacks resentful and distrustful. It had not always been the case, as at the first Native Executive Council, Le Roux was chosen unanimously by African leaders as their European Superintendent, and they even suggested that he give up some responsibilities in the European wing of the mission so that he might be able to dedicate more time to the "native work." However, by 1918 Black AFM leaders were distrustful of the ever increasingly paternalism on the part of the white Executive Council. Le Roux attempted to unite the black Zion Apostolic Church with the Apostolic Faith Mission, and requested prayer at the General Conference, "that God might work out the unity that was longed for," but he ultimately failed in this prerogative. ${ }^{108}$ By 1932 , no less than 112 Zionist groups had left the AFM as offshoots. ${ }^{109}$

The second major challenge was led by a female member named Martha Frazer in 1928. ${ }^{110}$ Born in Victoria West in the Karoo, South Africa in 1889,

${ }^{107}$ AFM Executive Council and Workers Conference Minutes, Book 1, July 7th, 1917. 135-136.

108 AFM Executive Council and Workers Conference Minutes, Book 1, July 19th 1918. 210.

${ }^{109}$ Allan Anderson, "African Pentecostalism," Studia Historia Ecclesiastica (XXII:2 1996 114-148), 121.

${ }^{110}$ Isak Burger presents the incidents of the Benoni Schism in detail in the AFM's official church history. See: Isak Burger and Marius Nel, The Fire Falls in Africa, 107-115. 
Frazer joined the Apostolic Faith Mission in Benoni in 1920. ${ }^{111}$ Frazer believed that the mission was spiritually "cooling down" and the people being led astray by worldly influences. She was critical of sins that she believed were not being addressed and the declining use of spiritual gifts in the church. Since her conversion in 1920 Frazer claimed to possess a gift of "sin revelation" by which she could see the hidden sins of others. ${ }^{12}$ Frazer was somewhat obsessed with repentance and purity, and argued that the Pentecostals were desperately in need of a revival to cleanse them from their sins. Beginning in 1927, Frazer and ten other women began meeting daily in the prayer hall in Benoni. They stressed the use of spiritual gifts, particularly that of prophesy and revelation. During these meeting Frazer claimed to have received visions of church leaders' sins and some claimed to have seen visions of unsolved murder and fraud cases. Frazer and the women developed a form of spiritual dancing, and began to use their own lexicon of phrases in their meetings. In the summer of 1927 the women began dressing in blue dresses and black shoes, earning them the nickname "Blourokkies" (Blue Dresses).

Led by Frazer and her husband, the group quickly took over the Benoni Assembly. Frazer and the group began publishing a paper called the Benoni Latter Rain Evangel under the auspices of the Apostolic Faith Mission. They also took control of the church hall by obtaining the keys and refused to relinquish

\footnotetext{
${ }^{111}$ Maria Martha Fraser, Getuienis van Geestelike Groei, van Geloofslewe en van Werkinge van die Heilige Gees (Benoni: Spade Reen Gemeentes van Suid-Afrika, 1974). 5.

112 Isak Burger and Marius Nel. The Fire Falls in Africa, 108.
} 
control to the Spiritual Committee. After numerous attempts to contact the mission via letters and representatives, the Executive Council sent the group a list of demands that included: 1) that the group "abandon" their peculiar manner of dress, 2) that they give up the practice of condemnation of sins by way of "revelation," 3) that they return the church hall's key, and 4) that they immediately cease printing of the Benoni Latter Rain Evangel. ${ }^{113}$ The group refused to relinquish control.

In the January 1928 issue of De Trooster, the Executive Council published a Kennisgewing (Notice) about the group. The council pushed back at the socalled revelations by the members that they claimed contradicted the teachings of the New Testament. ${ }^{114}$ The mission laid out the charges against the group, including their alleged "condemnations" about other members, and asked the readers to pray for them, that "their eyes may go open and that they will return to serve the Lord with a heart of humility." ${ }^{115}$ The AFM called the police to remove the group, but according to Frazer they were unsuccessful. ${ }^{116}$ Eventually, the AFM decided to sell the hall to another church. Frazer and the remainder of the

\footnotetext{
${ }^{113}$ Fraser, Getuienis van Geestelike Groei, van Geloofslewe en van Werkinge van die Heilige Gees, 30.

114 "Kennisgewing," De Trooster, January 1928, 10.

115 Ibid.

${ }^{116}$ Fraser, Getuienis van Geestelike Groei, van Geloofslewe en van Werkinge van die Heilige Gees, 30.
} 
Benoni group had to move on, but they successfully managed to continue their group under the name Spade Reën (Latter Rain). ${ }^{117}$

The Benoni schism indicates that women in the AFM South Africa could, and did, claim equity under the theology of the "democracy of the Spirit." Frazer and the other women at Benoni claimed to have special revelations from God that challenged the authorities in the church. Although no copies of Frazer's Benoni Latter Rain Evangel appear to still exist, the fact that the women printed the magazine indicates that they understood the importance of building textual communities. To an extent, their efforts paid off. Some AFM members circulated a petition at the General Workers' Conference in April 1928 to rebuke the Executive Council's disciplinary measures against the Benoni group. ${ }^{118}$ The minutes record that "many of the brethren spoke - some in favor - others against them," and that a sister van der Byl admonished the group, saying "the Holy Spirit always keeps us small and humble and submissive to those planted over us, and these people show a spirit of exaltation and pride." ${ }^{119}$ The AFM offered that any of the Benoni group that was willing to return to the AFM and "submit themselves to the doctrine and practice" of the mission would be welcomed back. Despite the offer, most of the Benoni group continued on and established what

\footnotetext{
117 Isak Burger and Marius Nel. The Fire Falls in Africa, 108.

118 Isak Burger and Marius Nel. The Fire Falls in Africa, 111.

119 Minutes of the Annual General Workers' Conference, Book 4, April 3-5, 1928. 1023-1024.
} 
amounts to a Dowiesque Zion-city in Jathniel, a small settlement just north of Benoni. Frazer led the movement there until her death in $1972 .{ }^{120}$

By 1928 the Apostolic Faith Mission was more financially stable and growing faster than ever, but it was also securely headed in the same ideological direction as that of the South African Government. Le Roux's tenure had stabilized and reinvigorated the mission, but at the cost of the original racial egalitarianism of the movement. Yet the theology of Holy Ghost Baptism allowed individuals to claim a role in a movement and form their own groups. The pattern of schism and reorganization had already resulted in dozens of Pentecostal groups in the U.S. and Europe. During the 1920s several of these groups came to South Africa as well. The pattern would continue on throughout the twentieth century. Despite schism, many of these groups remained connected through a vast transnational Pentecostal print network that continued to act as a medium for the exchange of encouragement, ideas, prayers, testimonies, and news. John G Lake, writing in 1927 to Charles Parham, expressed concern over the movement's increasing organization and denominationalism. The letter's tone was that of sadness as Lake concluded, "The world does not know what real Christianity is. Pentecost should have exemplified it. In that it has failed in my judgment about $93 \%$. However, it has done this much. It has demonstrated that there is such a thing as the baptism of the Holy Ghost. That men may enter into God if they will."121

\footnotetext{
${ }^{120}$ Isak Burger and Marius Nel. The Fire Falls in Africa, 113.

${ }^{121}$ Letter from John G. Lake to Charles Parham. March 24th, 1927. 1. Flower Pentecostal
} 
Heritage Center Archives. Springfield, MO. 


\section{CHAPTER 7:}

THE PNEUMA NETWORK: 1930s - 1948

This chapter examines the Apostolic Faith Mission from the 1930s to 1948 and its organ, The Comforter. The AFM grew exponentially during this period, becoming one of the largest denominations in the country. Scholars have attributed the high rate of growth during these years to the AFM's evangelism, laity, theology of missions, ecclesiology, and liturgy. ${ }^{1} \mathrm{I}$ argue that the mission's periodical played a critical role as the medium by which many of these factors were negotiated and developed. This chapter reasserts The Comforter's role in the history of the AFM by chronicling how the periodical transitioned from a localized mission paper to a Pentecostal magazine with an international scope. Towards this effort, this chapter investigates first, the social, economic, and political context of the era; second, the management of the paper under the tenure of Le Roux until 1930; third, the management of David Du Plessis beginning in the 1930; fourth, the evolution of the paper in format and content during the 1930s; and fifth, the full transformation of the paper in the 1940s into a cosmopolitan religious magazine.

In the 1930 s the country was rocked by the global effects of the Great Depression, which hit South Africa almost immediately. Afrikaner farmers were

\footnotetext{
${ }^{1}$ Christiaan Rudolph De Wet, The Apostolic Faith Mission in Africa, 1908-1980 A Case Study in Church Growth in a Segregated Society. (Ph.D. Diss., Cape Town, South Africa: University of Cape Town, 1989), 390.
} 
hit especially hard as the price of wool sank to record lows on the world market. ${ }^{2}$ The collapse of mineral exports was especially disastrous. ${ }^{3}$ Of its many effects, Afrikaners migrated into the cities, their percentage rising from 29 percent in 1910 to 50 percent in $1936 .{ }^{4}$ Poor whites worked alongside blacks, and racial issues flared. As one scholar notes ". . the economic problem (of the poor white) was interpreted as an interracial problem ... the problems that the whites (in this case almost exclusively Afrikaners) had to adapt to in the industrial city, was almost without exception seen as the "black danger." 5 Having lost the War, and being pressed into an increasingly British, and capitalist, way of life, many Afrikaners sought to revive what they viewed as their dying heritage.

As a result, the Depression fueled nationalist sentiments. Afrikaner hostility to British authority grew in the 1930s. Prominent South African academics and politicians pointed to the lack of unity in the white population as a major crisis facing the country. ${ }^{6}$ Anger over the lost South African War and its aftermath combined with economic desperation to fuel anger towards the

${ }^{2}$ The vast majority of agricultural production was done by Afrikaners, while British and Jewish people controlled a near monopoly on the non-agricultural economic sectors. See Giliomee, The Afrikaners: Biography of a People, 404.

${ }^{3}$ Davenport and Saunders, South Africa: A Modern History, 317.

${ }^{4}$ D. Prinsloo, "Die-Johannesburg-periode in Dr. H.F. Verwoerd se loopbaan," (Doctoral Diss., RAU, 1979), 27, as cited in Giliomee, The Afrikaners: Biography of a People, 405.

${ }^{5}$ Johann Kinghorn, Apartheidsteologie Binne de Kerk, Stellenboch, 1984. 9. Translated and cited in De Wet, The Apostolic Faith Mission in Africa, 1908-1980, 173-174.

${ }^{6}$ These crises were detailed in Edgar Harry Brookes, et al., Coming of Age: Studies in South African Citizenship and Politics. (Cape Town: Maskew Millar, 1930). Herman Giliomee discusses the book at length. See: Giliomee, The Afrikaners: Biography of a People, 405. 
imperial power. ${ }^{7}$ At the same time, blacks were beginning to challenge the racial policies of the government and assert their rights in the political sphere. As historian John De Gruchy notes, "The rise and development of Afrikaner Nationalism requires to be seen primarily as a reaction against British imperialism on the one hand, and growing Black Nationalism on the other." ${ }^{8}$

These underlying tensions came to a head at the outbreak of World War II, which put the Union of South Africa in a political dilemma. As part of the British Commonwealth, the Union of South Africa was obliged to assist Britain in the fight against Germany during the war, but the government was divided over the issue. ${ }^{9}$ When Britain joined the war to defend Poland, an intense debate erupted in the South African Parliament over how to respond, with division occurring along clear ethnic lines. The South African Prime Minister J.B.M. Hertzog, an Afrikaner, desired to remain neutral or even join the pro-Axis powers. ${ }^{10}$ The rest of the United Party, led by Jan Smuts, desired to enter the war on Britain's side. Hertzog's faction ultimately left the United Party over the Union's entrance into

\footnotetext{
${ }^{7}$ De Wet, The Apostolic Faith Mission in Africa, 173-174.

${ }^{8}$ De Gruchy, The Church Struggle in South Africa, 26.

${ }^{9}$ The ruling political party was the United South African National Party, which had formed as a result of the Great Depression by uniting the pro-Boer National Party led by J.B.M. Hertzog with the pro-British South African Party led by Jan Smuts.

10 The Afrikaner population still remembered their treatment at the hands of the British during the South African War and recoiled at the thought of fighting for them in what they viewed as a primarily European problem.
} 
WWII, but reorganized and won the elections of 1948 on a platform promise to uphold white rule. ${ }^{11}$

Some of this conflict appeared in the AFM's response to the War and military service. Like the country's government, the leadership of the AFM was divided over whether or not to support the War. The War put them in the uncomfortable position of having to stake out a political position, something that the AFM generally tried to avoid. Most of the mission's leadership were Afrikaners, but there was a significant minority of British members. Pentecostals were by their nature disinclined to join military service, as historically, Pentecostals tend to be pacifists. ${ }^{12}$ The AFM ultimately looked to the U.S. Assemblies of God (AOG) as an example. During WWI the U.S. Assemblies of God expressed the sentiment:

Therefore, we, as a body of Christians, while purposing to fulfill all the obligations of loyal citizenship, are nevertheless constrained to declare we cannot conscientiously participate in war and armed resistance which involves the actual destruction of human life since this is contrary to our view of the clear teachings of the inspired Word of God, which is the sole basis of our faith. ${ }^{13}$

\footnotetext{
${ }^{11}$ Giliomee, The Afrikaners: Biography of a People, 439-445.

12 Jay Beaman is one of the foremost scholars on this subject. See Jay Beaman, Pentecostal Pacifism: The Origin, Development, and Rejection of Pacific Belief Among Pentcostals. (Hillsboro, Kan: Center for Mennonite Brethren Studies, 1989); and Jay Beaman and Brian K. Pipkin, Pentecostal and Holiness Statements on War and Peace. (Eugene, Oregon: Pickwick Publications, 2013). Some other scholars, such as Edith Blumhofer and Murray Dempster, disagree that pacifism was a broadly accepted article of faith in Pentecostalism. See: M.W. Dempster, "'Crossing Borders': Arguments Used by Early American Pentecostals in Defense of the Global Character of Pacifism," in Paul Alexander and Stanley Hauerwas. Pentecostals and Nonviolence: Reclaiming a Heritage, (Eugene, Oregon: Pickwick Publications 2012); and Edith Blumhofer, "The Christian Catholic Apostolic Church and the Apostolic Fatih: A Study in the 1906 Revival," in Robeck, Cecil M. Charismatic Experiences in History. (Peabody, Mass: Hendrickson Publishers, 1985).

${ }^{13}$ General Council Combined Minutes 1914-1917 (Springfield, MO: Gospel Publishing House,
} 
The AFM looked to this stance by the AOG in forming their position on WWII involvement. The Comforter reprinted a paraphrased article from The

Pentecostal Evangel by E.S. Williams, the General Superintendent of the

Assemblies of God, U.S.A. that appealed for a contentious objector status:

...it may not be long before the world will again be enveloped in a great European, and probably world-wide conflict... The Government of the United States has been kind in the past in that it has recognised [sic] genuine 'conscientious objectors' and has provided for them

"noncombatant' service. It is our hope that it will be as kind in the future... While purposing to fulfill all the obligations of loyal citizenship, are nevertheless constrained to declare we cannot conscientiously participate in war and armed resistance which involves the actual destruction of human life, since this is contrary to our view of the clear teachings of the inspired Word of God, which is the sole basis of our faith. ${ }^{14}$

The stance did not fully advocate the total abstention from assisting the State during war however, allowing space for individuals to decide how much they could consciously support the cause. It continued:

Since none can escape some relationship to the war, it then becomes necessary that the "recruit" who is called into military service determine what he is willing to do and what he feels he could not conscientiously do. Could not such a one serve as a cook, a helper in a hospital, a stretcher carrier, a driver of an ambulance, or of a truck? There are many services which one could fulfill without 'armed resistance which involves the actual destruction of human life.' 15

The editors made clear that "The Executive Council of the Apostolic Faith

Mission fully endorses the above statement." ${ }^{16}$ Yet not all AFM members were

1917), 11-12.

14 "In Case of War," The Comforter, November 1938, 5.

15 lbid.

${ }^{16}$ lbid. 
satisfied with the mission's pacifist stance or the fact that the mission had taken what they saw as a worldly political position.

Such politically wrought decisions played out in the pages of The Comforter. Many members in the AFM found fault with the mission's decision regarding wartime involvement. In the December 1940 issue, the Executive Council responded to the outcry, writing:

The Executive Council wishes to declare that this article was never published with even the slightest political motive. Nor the Executive Council, not those who had anything to do with the publication of this article are imbued with any political feelings. We hereby make an appeal to God's people not to associate themselves with any political movements. We regret to hear that some of our readers have attached political value to articles that have been published with the very best intentions, and we want to assure our readers that in future attention will be given to prevent the publication of anything that might have a political calour. ${ }^{17}$

Such attempts to remain overtly apolitical also explain the mission's reluctance to challenge the State's other controversial policies during this period, including growing segregation.

As the Depression and War reverberated through the AFM, racial issues came increasingly to the forefront as well as the government tightened rules governing racial mixing. ${ }^{18}$ This period witnessed the continued political disenfranchisement of non-white South Africans. A series of bills passed in the 1920s served to increasingly segregate blacks and deprive them of political

\footnotetext{
17 The Comforter-Trooster, Nov-Dec, 1940. 5.

${ }^{18}$ George M. Fredrickson, White Supremacy: A Comparative Study in American and South African History. (New York: Oxford University Press, 1982), 240.
} 
representation. The Mines and Work Amendment Act of 1926 barred black and Indian workers from specialized or upper management jobs in the mining industry. ${ }^{19}$ The 1927 Native Administration Act set up a separate legal system for administrating Africa law and stated that the South African Governor-General was essentially a "supreme chief of all natives."20 The Governor-General was not subject to parliamentary oversight and could rule by decree, thereby continuing the process of transferring power from parliament to executive. The 1936 Native Lands and Trust Act extended the 1913 Native Lands Act by increasing the land set aside for reserves from $7.3 \%$ to $13 \%$ and prohibiting ownership or purchase of land by natives outside these reserves. This was later followed by the Asiatic Land Tenures Bill in 1946 which banned the sale of land to Indians.

The AFM submitted to these policies, spurred by ideological, pragmatic, and theological reasons. Ideologically, by the 1920s the AFM leadership held to roughly the same stance as the government on the idea of racial hierarchies, saying "we do not teach or encourage social equality between the whites and Natives." ${ }^{21}$ Segregation was the norm in the churches. One Pentecostal recalled

\footnotetext{
${ }^{19}$ Francis Wilson, Labour in the South African Gold Mines 1911-1969. (Cambridge, England: University Press, 1972), 11.

20 The Governor-General of the Union of South Africa was the representative of the British (19101931) and later South African Crown (1931-1961) in the Union of South Africa between 1910 and 1961. Mahmood Mamdani, Citizen and Subject: Contemporary Africa and the Legacy of Late Colonialism. (Princeton, N.J.: Princeton University Press, 1996), 71.

${ }^{21}$ Minutes of the Workers' Conference of the Apostolic Faith Mission, July 7th, 1917. 135-136. Apostolic Faith Mission Archives, Auckland Park Theological Seminary, Auckland Park, Johannesburg, South Africa.
} 
shock when visiting America that in a crowd of twelve hundred people "more than a third" were black and "the blacks and whites were mixed together. This was unheard of in South Africa."22 Pragmitism encouraged the same ends. For one thing, the increasing separation of blacks to reserves made it easier to evangelize. For another, the AFM had fought hard in its early years to win recognition from the government, so in order to improve its standing with state authorities it conceded on the issue of segregation. ${ }^{23} \mathrm{~A}$ loss in governmental recognition would have been devastating to the AFM, as official recognition was required for a host of intrinsic matters, including church building permits, reduced cost rail tickets for ministers, and passes for workers. ${ }^{24}$ Finally, the AFM pointed to scripture to defend its stance on submission to the government authorities.

The Depression rattled the financial standing of the mission in the 1930s, despite Le Roux's stabilization of the mission's organizational structure in the preceding decades. Congregational tithing slumped and during some months the mission was unable to pay their workers in the field. ${ }^{25}$ Rapid expansion during the 1920s left many of the mission's assemblies and building projects in tenuous positions when the Depression hit. ${ }^{26}$ The worst of these was the mission's

\footnotetext{
${ }^{22}$ Du Plessis and Slosser, A Man Called Mr. Pentecost, 96.

${ }^{23}$ Governmental recognition required that black workers and ministers work under the supervision of white overseers.

${ }^{24}$ Black workers had to have signed passes to work in certain areas. See De Wet, The Apostolic Faith Mission in Africa, 163.

${ }^{25}$ AFM Executive Council Minutes, February 15 ${ }^{\text {th }}, 1932$, Book 5, 1285.

26 Isak Burger and Marius Nel, The Fire Falls in Africa, 117.
} 
headquarters at 73 Kerk Street in Johannesburg, where the group had committed to renovating in 1929, just before the collapse. "The Residency" as it was known, drained the mission's finances during the 1930s and was the mission's largest source of debt. ${ }^{27}$ The Residency was eventually sold in 1934, and the members at the annual Workers' Conference that year resigned 'That we as a Workers' Conference express our thanks to God for having delivered us from this financial burden and pledge ourselves not to enter into commercial propositions as hereforto." ${ }^{28}$ Furthermore, as Isak Burger relates, the Executive Council had encouraged church members to invest their money with the Head Office of the mission during the 1920s instead of in banks. ${ }^{29}$ The Executive Council issued a supplement in an issue of The Comforter detailing the mission's financial position in response to "many rumors that are being spread." 30

Despite such woes and conflicts, the era witnessed continued growth and expansion for the AFM. AFM President Isak Burger writes that these years "could have possibly been the AFM's best year's ever - quantitatively, financially, and

\footnotetext{
${ }^{27}$ Burger and Nel, The Fire Falls in Africa, 117.

${ }^{28}$ Minutes of the Annual General Workers' Conference, March 26-30, 1934. Book 5, 1494.

${ }^{29}$ Burger and Nel, The Fire Falls in Africa, 117.

${ }^{30}$ The AFM listed their assets at $£ 101,83913$ s $4 d$, and their total liabilities at $£ 48,54212 \mathrm{~s} 7 \mathrm{~d}$. As an unlimited company, the assets of the company would be confiscated in the case of bankruptcy. Members who asked for their money back put even more pressure on the mission, which was attempting to keep afloat with all of its outstanding debts on properties. Many members resigned in protest over what they saw poor financial management by the Executive Council. "Supplement to The Comforter," The Comforter Trooster, October 1932.
} 
spiritually." ${ }^{31}$ While the mission failed to keep detailed records of the members, various sources affirm Burger's assessment of growth. In 1929 The Comforter reprinted the results of a state census that revealed the AFM had grown $100.77 \%$ in the 1921-1926 period, the highest rate of all denominations in South Africa. ${ }^{32}$ The numbers of white members rose from 7,742 to 15,544 in just five years. Of these, 12,757 reported as being of Dutch South African heritage, 1,225 as British South Africans, 523 as Germans, 499 as English, and the remainder a mix. ${ }^{33}$ The AFM looked to theology for the source of growth:

Candidly speaking, we consider that such must be contributed to the extraordinary effect on the masses of the simple Gospel Message, preached by ordinary men in the power of the Holy Spirit, and backed by consecrated and sanctified lives. When so preached, the power of the Gospel through all the ages has proved invincible. ${ }^{34}$

The General Treasurer J.H. Saayman mentioned that as of 1930 the white branch of the AFM had twenty thousand followers. ${ }^{35}$ The black, colored, and Indian member numbers are more difficult to ascertain, but

The leadership of David Du Plessis accounts for much of this dynamism. Du Plessis (1905-1987) was elected to the Executive Council in 1932, and served as General Secretary of the AFM from 1936 until $1947 .{ }^{36} \mathrm{He}$ had been a

\footnotetext{
${ }^{31}$ Burger and Nel, The Fire Falls in Africa, 121.

${ }^{32}$ For comparison, the Lutherans came in second place at $22.37 \%$ growth.

${ }^{33}$ The Comforter, July-August 1929, 11.

${ }^{34}$ The Comforter, July-August 1929, 11.

35 This only includes the white members. The Comforter, June 1930, 6.

${ }^{36}$ Du Plessis and Slosser. A Man Called Mr. Pentecost, 64.
} 
long-time member and a Pentecostal since the age of eleven. ${ }^{37} \mathrm{He}$ implemented major changes in the way the mission functioned. One of the most critical changes that Du Plessis initiated was ending white control of the non-white assemblies. He helped to wrest control of the mission from the Executive Council and return control of the native work to Africans. This controversial move ended the mother-daughter relationship between the churches. Each had their own constitution, and "the authority of the local church was established and prevailed." 38 The AFM explained the move toward decentralization as the result of extensive expansion. "Owing to the growth of the work here, the Distric [sic] council could not attend to the non-European work as they should, so it was decided that the assemblies of coloured work should establish their own council," The Comforter explained. ${ }^{39}$ Yet while this gave the non-white churches more autonomy over their affairs, the changes ultimately resulted in the mission reflecting the "separate but equal" ideal of racial segregation, with separate white, black, coloured, and Indian churches. The separation can be seen in The Comforter, which from the 1930s onward devoted very little space to any nonwhite issues or news.

Du Plessis' influence on the trajectory of the AFM during the 1930-1948 period is best viewed through his work with The Comforter. Prior to the 1930s

\footnotetext{
${ }^{37}$ Du Plessis and Slosser. A Man Called Mr. Pentecost, 27.

${ }^{38}$ Du Plessis and Slosser. A Man Called Mr. Pentecost, 112.

${ }^{39}$ Comforter-Trooster, January, 1940.
} 
funding for the paper was a constant problem, as the mission was barely able to pay its workers, let alone print and mail thousands of issues of their periodical. In 1932 the Executive Council reported at the Annual General Worker's Conference that The Comforter was not being published because the Publication Department held debts of $£ 1000.40$ That year alone, the Publication Department records showed that receipts for sales were just over $£ 62$, while the annual expenditures were over £432. ${ }^{41}$ At the appeal of some members, including Du Plessis, the group decided to revive the publication under a new five-person Publication Committee that would work with the Executive Council. ${ }^{42}$ Yet significantly, the Executive Council would no longer bear financial responsibility for the publication. ${ }^{43}$

The new publication committee elected Du Plessis as the managing editor of The Comforter, and his managerial sense guided the paper to stability and growth over the next two decades. ${ }^{44}$ When he took over, Du Plessis recounted that it was "in bad shape financially" and hadn't issued a single issue in over six

\footnotetext{
40 The last issue had gone out in November, 1931. "Minutes of the Annual General Workers' Conference," AFM Executive Council Minutes, March 24 ${ }^{\text {th }}, 1932$, Book 5, 1298.

41 "Minutes of the Annual General Workers' Conference," AFM Executive Council Minutes, March $24^{\text {th }}, 1932$, Book 5, 1300.

${ }^{42}$ AFM Executive Council Minutes, March 24 th, 1932 , Book 5, 1298-1299. This was revised to an eight-person publication committee by May, comprised of P.L. Le Roux as Editor, David Du Plessis as Managing Editor, and B. Opperman, J.G. Henning, J.T. Odendaal, C. J. Terblanche, J.H. Saayman, and A.W. Preller as Associate Editors. See The Comforter-Trooster, May 1932, 1.

${ }^{43}$ AFM Executive Council Minutes, March 24 ${ }^{\text {th }}, 1932$, Book 5, 1298-1299.

44 The Comforter-Trooster, May 1932, 1.
} 
months. ${ }^{45}$ His first course of action was to save the publication from insolvency.

Du Plessis went before the committee and outlined his plan for saving the paper:

...my scheme for farming the printing of the paper out to the commercial print shop in Bethlehem...was a good one, thus avoiding the expense of operating and maintaining our own costly equipment. I would work directly at the shop, doing a lot of the tasks myself and directing the printers first hand. I would immediately set up circulation program with all the churches, in which they would pay in advance for so many papers and then sell them for cash themselves at a slight profit. That way I would have enough money to pay for an issue even before it came off the press. ${ }^{46}$

The committee agreed to give Du Plessis full managing control of the paper and he immediately implemented his plan. The committee promptly leased out their printing offices to a local printer in exchange for free printing for 4,000 copies of The Comforter-Trooster every month. ${ }^{47}$

Du Plessis' strategy worked spectacularly. It appeared in the transformation and increased output of The Comforter in the 1930s. Beginning in 1932, the mission consistently produced the periodical on a monthly basis, and the issues expanded dramatically from 8-14 pages to 28-32 pages. The main reason for the extended length was that the mission decided to begin printing the paper in combined English and Afrikaans issues, ${ }^{48}$ as Du Plessis had suggested.

\footnotetext{
${ }^{45}$ Du Plessis and Slosser, A Man Called Mr. Pentecost, 68.

${ }^{46} \mathrm{lbid}, 69$.

47 AFM Executive Council Minutes, October 23rd, 1930, Book 5, 1190; "Memorandum of Agreement," supplement. In AFM Executive Council Minutes, December 18th, 1930, Book 5, 1201.

48 The Comforter Trooster, May 1932, 12.
} 
The pages of the paper reveal a commitment to boosting subscriptions. He asked in the January 1933 issue:

Is 1933 going to be just another grand opportunity to improve our paper and to increase the circulation 100\%? Yes! Praise God. Let us stand together and push the publication of our paper ahead with all our might! WHY? Because it is the largest and most widely-read Pentecostal paper in South Africa and it propagates the Truths of God's Word faithfully in places where our preachers never come. If you want your relatives and friends to know the TRUTH, then send them a "COMFORTER." 49

Everything from the design to the more varied articles indicated that the editors were competing for readers' attention. Du Plessis' goals for the periodical went beyond improving it for a local South African AFM audience, as indicated in a statement introducing the new changes to the paper: "We hope to continue to make improvements until our paper will be one of the leading journals in Pentecostal literature."50

By the 1930s the Apostolic Faith Mission was not only competing with other missions, but also with other Pentecostal groups. By the mid-1920s there were several other Pentecostals groups who published their own papers in competition with the AFM. Jacob O. Lehman, who had arrived with the initial group from Azusa but had left to continuing his ministry at the mines in Kimberley, published a paper entitled Africa's Advocate, beginning in 1918. The Full Gospel Mission and Assemblies of God arrived on the South African scene in the 1930s. They immediately began publishing their own papers. By 1921 the

\footnotetext{
49 The Comforter Trooster, January 1933, 3.

50 The Comforter Trooster, May 1932, 2.
} 
Full Gospel Church in Pretoria was printing a periodical entitled the South and Central African Missionary Herald. ${ }^{51}$ The editors acknowledged the additional competition:

Every reader may become an agent to assist us along the road to success. If you like this beloved messenger in its present form, tell your friends about it and ask them to buy a copy regularly. If you don't like it, tell us, and give us your suggestions for improvement. Remember it is "OUR PAPER" and "WE" (you and I) are expected to do all we can to make it the most brightest and most interesting pentecostal paper. ${ }^{52}$

By 1932 The Comforter had a regular circulation of 4,000 and the editors were hoping to reach 5,000 copies monthly. ${ }^{53}$ Du Plessis advanced his committee proposal in The Comforter that each assembly set up representatives for the paper who would "sell as many 'Comforters' as possible every month" and keep the editors posted with news from each community. ${ }^{54}$ By instituting this system of selling issues, Du Plessis ensured steady revenue streams for the paper.

Du Plessis changed the paper in every way. First, it became fully bilingual, with all content reproduced in Afrikaans and English. Second, the Publication Committee relied on advertising to fund the magazine and marketing to sell it. Third, the format evolved to make the periodical attractive to more than just the casual AFM reader. Finally, the magazine sought a wider audience through a

\footnotetext{
${ }^{51}$ Later called the Full Gospel Missionary Herald in 1921. This periodical was based from the Bethel Pentecostal Assembly in Newark, NJ. The Full Gospel Church established a mission in Pretoria.

52 The Comforter-Trooster, May 1932, 6.

${ }^{53}$ The Comforter-Trooster, July 1932, 2.

54 The Comforter-Trooster, May 1932, 2.
} 
concerted effort to make the content more cosmopolitan and relevant in the lives of its readers. Thus, one of Du Plessis' first acts as managing editor was to send The Comforter to "every Pentecostal movement in the world, trying to get feedback from them and to receive their publications." 55 Through this and "heavy correspondence" Du Plessis established important contacts within the worldwide community of Pentecostals and gained valuable insight into the business of religious publishing. Under the direction of Du Plessis, the editors fundamentally changed the look and content of the paper, ultimately transitioning it from a mission newspaper to a modern Pentecostal magazine.

Du Plessis first instituted bilingualism at the paper. The first fully bilingual issue appeared in May 1932. The content was printed side-by-side in each language, sometimes alternating pages. Du Plessis recognized the importance of printing a bilingual paper, suggesting in his plan that he laid before the committee, "I would at once make the paper bilingual." 56 The decision to make the paper bilingual was a sound decision by Du Plessis, due to the fact that most white AFM members were bilingual and the vast majority spoke Afrikaans. Of the 15,554 members listed in a 1929 survey, 9,981 were bilingual, 5,056 spoke Afrikaans, 499 spoke English, and 8 reported as neither or unspecified. ${ }^{57}$ Thus English-only versions of the paper left out fully one third of the members. An

\footnotetext{
${ }^{55}$ Du Plessis and Slosser, A Man Called Mr. Pentecost, 91.

56 lbid, 69.

57 The Comforter, July-August 1929, 10-11.
} 
Afrikaans-only option, meanwhile, severely limited the reach of the paper to nonSouth Africans.

Du Plessis also resolved the funding issues. He seized advantage of financial independence from the Executive Council to seek all available forms of funding. In 1932 the publishing committee made the decision to begin printing advertisements in the paper in order to raise revenue for its publication. This was a dramatic step away from their early resolution to never use advertisements, as the editors explained:

No secular advertisements have ever been published in this paper before. We are, however, now compelled to take up advertisements in order to make sure that it is going to be a self-supporting business. We sincerely hope that none of our readers will be offended at any of the adverts and we shall endeavor not to publish any against which you may have conscientious objections. We shall be much obliged if you will assist us and send us your advertisements of births, marriages, engagements, and deaths, for publication in our advertisieng [sic] columns, at the stipulated rates. ${ }^{58}$

The advertisements were relegated to the back cover of the magazine and were charged at the rate of $1 \mathrm{~d}$ per word for the first insertion and half for subsequent insertions. ${ }^{59}$

The advertisements provide a fascinating look at the lives of the members of the AFM. The first advertisements after this new policy included a birth announcement, a notice for the sale of The Comforter articles as tracts, an

\footnotetext{
58 The Comforter-Trooster, May 1932, 2.

${ }^{59}$ The Comforter-Trooster, May 1932, 25.
} 
advertisement for printing services from the mission, and a notice entitled "confession" that read:

Dear Saints of the AFM, I the undersigned wish to ask for your forgiveness in the name of our Dear Lord Jesus for making false accusations against, speaking evil of, and criticising [sic] the people and workers of God while I was in a Backslidden condition. I have repented of my evil ways and ask for your kind forgiveness. Your sister, J. Asmus. Pretoria. ${ }^{60}$

Thus the back pages of The Comforter became a public square for the selling of religious literature alongside the exchange of social notifications. Birth announcements, engagements, in memoriam, and public notices were just some of the entries allowed. Empty sections encouraged readers to "Advertise in The Comforter." The local Bethlehem Board of Executors \& Trust Company was one of the first major advertisers, offering interest rates of $5-8 \%$ on mortgages and deposits. ${ }^{61}$ Furthermore, the editors began engaging in commercial tactics to promote the paper and gain more subscribers. One tactic was to offer a free Bible to readers who could get twelve people to subscribe to the paper. ${ }^{62}$

The advent of commercialism in The Comforter had many repercussions. In addition to selling advertisement space, the editors realized that they could profit from selling other literature, printing materials, and paraphernalia. Beginning in 1929, they printed advertisements for these items on the back cover. Among the items they regularly advertised was a scripture calendar,

\footnotetext{
60 The Comforter-Trooster, May 1932, 25.

61 The Comforter, May 1932, 28.

62 The Comforter, August 1927, 11.
} 
monographs, hymn books, and buttons. ${ }^{63}$ The scripture calendar advertisement took up nearly the entire back page, and was sold as a "wonderful value" and “ideal gift," containing 13 "Famous Paintings." The ad suggested "By placing the 1929 scripture text calendar in every home in the community, you are performing a truly great work — paying you big dividends both morally and financially." ${ }^{4}$ Although calendar sales are not extant, they must have turned a profit as the periodical continued to sell them for the next decade and the production value clearly increased over time. The 1936 edition, for example featured an image of the biblical nativity scene, and the bold caption underneath read "A Text for Each Day! A Lesson For Each Week! A Picture for Each Month!"65

These religious objects served in many ways to not only forge a Pentecostal identity for the owners, but increasingly, a particular AFM identity. The mission had adopted a logo at its establishment, although its first appearance in The Comforter appears to be 1913, and it was rarely used until the mission began selling these items in the 1930 s and 1940 s. ${ }^{66}$ Items like the scripture calendar and buttons featured the official Apostolic Faith logo, which featured a cross situated inside a crown, with light shining from the background. ${ }^{67}$

\footnotetext{
63 The Comforter, January 1930, 12.

64 The Comforter, April 1929, 12.

65 The Comforter, September 1935, 32.

66 The Apostolic Faith Mission of South Africa, "AFM Name and Logo", accessed March 3, 2016. http://www.afm-ags.org/afm-name-and-logo.

${ }^{67}$ The first use of the logo in the Comforter is on the front page of the 1913 issue. It was not used again until 1932.
} 
The cross and crown in combination was a theme that derived from the nineteenth century American holiness movement and the later Zionists in Chicago. ${ }^{68}$

Christian books also proved financially beneficial. The Comforter advertised a range of evangelical books by famous evangelical authors, faith healers, and Pentecostals. Their bookstore, "The Pentecostal Book Room" in Johannesburg, served as a profitable outlet for the mission. ${ }^{69}$ The book assortment featured a range of European, American, and South African authors, including British evangelist and faith healer Smith Wigglesworth, leading evangelist Albert Benjamin Simpson, ${ }^{70}$ South African minister Andrew Murray, Chicago radio evangelist Paul Rader, and Pentecostal minister Thomas Ball Barrat. ${ }^{71}$ Alongside these big names they featured local authors publishing primarily in Afrikaans. ${ }^{72}$

The sale of Christian books also advanced the Pentecostals' evangelical agenda and helped construct a textually defined community of believers. The long-running literature advertisements for Maria B. Woodworth-Etter (1844-1924) books in The Comforter illustrate this point. Woodworth-Etter was a famous American healing evangelist, who at the age of 68 joined the Pentecostal

\footnotetext{
68 The Apostolic Faith Mission of South Africa, "AFM Name and Logo", accessed March 3, 2016. http://www.afm-ags.org/afm-name-and-logo.

69 "Books We Recommend," Comforter-Trooster, June 1929, 21.

${ }^{70}$ Founder of the Christian and Missionary Alliance.

${ }^{71}$ Barratt was the founder of the Pentecostal movement in Norway.

72 The Comforter-Trooster, June 1939, 21.
} 
movement in 1912. In 1924, just two months after Woodworth-Etter's death, a woman testified in The Comforter that she had written to Woodworth-Etter in America and had received a reply with an anointed cloth, which healed her instantly. ${ }^{73}$ One year later, the magazine began selling copies of WoodworthEtter's books. ${ }^{74}$ Woodworth-Etter's books included dramatic descriptions of intensely spiritual meetings, conversions, and accounts of divine healings. They also included her sermons on the same subject. They offered six books: Signs and Wonders, Marvels and Miracles, Questions and Answers on Divine Healing, Spirit Filled Sermons, Holy Ghost Sermons, The King's Herald, and Life \& Testimony. Calling her "one of the greatest Evangelists of the century," the editors plugged her books exhaustively, saying "many people receive faith while reading it and get saved, and healed, and baptized with the Holy Spirit." 75 The Comforter thus served as the medium through which South African AFM members gained access to new Pentecostal literature that reinforced their beliefs and reaffirmed their sense of membership in a global community of believers.

The Second World War revealed the geographical extent of this Pentecostal textual community. The Comforter rhetorically and actually invested in the War effort, supplying the medium for AFM members to help their brethren overseas. While the mailing lists have not survived, one can get a sense of the

\footnotetext{
73 "Ik ben de Here, Uw Heelmeester: Een Getuigenis," [l am the Lord, Your Healer: A Testimony] De Trooster, Nov-Dec 1924, 15.

${ }^{74}$ De Trooster, Dec 1925, 11.

75 The Comforter, March 1926, 11.
} 
displacement of the magazine through the letters and articles published in its pages. In the lead up to the War, the editors published reports from European Pentecostals in France, Germany, Belgium, and Finland, who described great revival despite an increasingly tense political atmosphere. ${ }^{76}$ During the War AFM Pentecostals sent food packages to their brethren in Europe. ${ }^{77}$ Some German Pentecostals wrote back to the editors and their letters were published in the July 1948 issue:

I have been driven from my home in Danzig and have lost everything. I also lost my husband and son and the only thing I have left is my precious Saviour...I have opportunity to work in the assembly and help Pastor Yung with music and Gospel in song. He has sent me his wonderful parcel so that I may not suffer hunger in the work of the Lord.

A woman named Emma asked:

Forgive me for approaching you with some requests whether you do not have some old clothes and shoes to clothe ourselves with. Since 1945 we have been living in a damp air-shelter after we had been bombed out of our house in 1943...my husband and son were prisoners of war and have nothing to wear except their uniform.

A teacher from Hamburg wrote in gratitude:

Dear Ones in Africa, Today is Easter, the resurrection day...This I have experienced again through your love to us. With tears in our eyes we looked at the things and did not know whether we deserved the things and wondered if we would have done the same if we had won the war...Distance makes not difference even as help comes from the very south of Africa. ${ }^{78}$

Such letters informed The Comforter subscribers of the events and need in other parts of the world. European Pentecostals wrote letters and reports of the state of

\footnotetext{
76 The Comforter-Trooster, June 1935, 16-19.

77 The Comforter-Trooster, May 1947, 16; August, 1947 22; November 1947, 18.

78 The Comforter-Trooster, July 1948, 18.
} 
their countries that were reprinted in Pentecostal magazines around the world. Such correspondence suggest the extent to which this transnational network of Pentecostal periodicals helped provide tangible support and aid for those in need.

Over the course of the 1940s The Comforter transformed into a modern magazine in terms of design, content, and audience. These transformations demonstrate a trend towards adaptation of the sacred to the modern in their use of the periodical. From the first issue in 1908 until the appointment of Du Plessis in 1932, The Comforter had remained essentially unchanged in form. In the 1930s the paper's content once again began to shift, but the real transformation came in the new aesthetics of the paper that moved away from the bland black and white, text-heavy style of a newspaper, to the colorful, image-heavy eyecatching design of a popular magazine. In 1930 the editors settled on a masthead and logo in a unique typography for the paper, where the previous year had featured a simple title. The iconography was striking. The print was in color, which drew the eye to its bold design that featured the title "COMFORTER" in huge bold blue font, curved over the image of a flying dove positioned between the subtitle "And Messenger of Hope." Two light posts justified the left and right margins of the cover, supported by an illustrated brick foundation with a plaque that read "Jesus Christ Himself the Chief Cornerstone." The center of the page contained the table of contents. In the 1940s the aesthetics evolved almost constantly, ever towards more color and imagery. Many of the front covers in the early 1940 s for example, feature photographs of various nature scenes in South 
Africa. Others prioritize photos of AFM buildings or gatherings, many in full color. $^{79}$

Another new design element included images and cartoons, beginning in the mid-1930s. The editors employed typical Christian imagery such as praying hands, bibles, crosses, and Bible scenes to break up the text between articles. The editors used cartoons to illustrate spiritual lessons such as the virtue of keeping busy, or theological concepts like divine healing. ${ }^{80}$ By the 1940 s the magazine was including photos. They featured photos of their buildings and their members, but sometimes included photos of their missionary work as well.

This transformational period also witnessed the democratization of the contents of the periodical. The first step was the opening up of the paper to all members of the AFM. Previously, the paper had published articles and sermons from ministers, and workers officially recognized by the AFM, but in 1932 the editors changed to welcome a wide range of submissions from all members. This change produced a renovation in format, with new headings: articles and sermons, "Good News from the Fields," "Missionary Tidings," praise and prayer requests, "Reports from Y.P.U.S.," ${ }^{81}$ testimonials, and items of other interest. ${ }^{82}$ The editors asked for sermons but also entreated readers to submit "as many

\footnotetext{
79 The Comforter-Trooster, January 1930, 1.

80 The Comforter-Trooster, August 1948, 13; The Comforter-Trooster, March 1948, 9.

81 Youth People's Union

82 The Comforter Trooster, May 1932, 2.
} 
original articles as possible," and "bright but short essay on a topic that is burning in your soul." ${ }^{83}$ Assuring potential authors that they would "brighten" up even the poorest-written essay, the editors thus opened up the paper to all its readers. Contributions from all readers regardless of member status reinforced the Pentecostal notion of the "democracy of the Spirit" and the larger Protestant belief of the "priesthood of all believers." 84

Missionary articles bolstered the sense of a global community of believers, and contributed to an increasingly cosmopolitan essence of the magazine. W.F. P. Burton, a Pentecostal missionary to the Belgium Congo, was a prolific author and published many articles in The Comforter. He had close ties to the AFM and even wrote a biography of Elias Letwaba, which was heavily promoted during the 1930s. Pentecostals from around the world contributed articles to the paper, including Charles Robinson, Percy G. Parker, Carrie Judd Montgomery, A. B. Simpson, and E. Hodgson. Yet increasingly, many featured authors were nonPentecostals. Another missionary that the AFM heavily promoted was the Baptist Reverend F. B. Meyer (1847-1929). Meyer wrote and traveled extensively throughout his years as a missionary, evangelist and author, becoming close

\footnotetext{
${ }^{83}$ The Comforter Trooster, May 1932, 6.

${ }^{84}$ Candy Brown expands on this idea in The Word in the World: Evangelical Writing, Publishing, and Reading in America, 1789-1880, 176.
} 
friends with other famous Christian leaders like Dwight L. Moody and A.C. Dixon. In addition to his articles, The Comforter advertised Meyer's books as well. ${ }^{85}$

Finally, as a magazine, The Comforter sought a wider audience by appealing specifically to diverse groups. They did so mainly through regular sections devoted to special interests. Children and youths proved especially dedicated to the magazine. In one letter, a young Mary Gootam from Amalapuram, South India asked:

May an Indian girl join your happy band of boys and girls? Father has been taking the "Comforter" from long before I was born. We cannot do without it. My parents and brothers will be eagerly waiting for its spiritual message each month. Really we are blessed and comforted very much by keenly studying the good pages of the "Comforter"... I am fourteen years old and am a member of the Indian Christian Faith Mission, which my father started nearly 20 years ago. Perhaps several times you might have heard through the pages of this paper the endeavors of my father in establishing this Mission here in the remote parts of India...My hobbies are reading, music and correspondence. I would like to hear from boys and girls of the band, and I assure you that I shall try to answer them all. ${ }^{86}$ Mary's query referred to the children's section in The Comforter called "Children's Band" or "Kinderbende." The Children's Band was a club open to children under the age of sixteen, and was a way to broaden the appeal of the paper to the whole family by getting children interested and invested. Children were encouraged to write in to a character called "Uncle John" with their names in order to join and become a "bandmember." The Children's Band section encouraged children to good behavior including Sunday School attendance,

\footnotetext{
85 The Comforter, Dec-Jan 1923, 12.

${ }^{86}$ The Comforter-Trooster, September 1939, 32.
} 
Bible reading, donating to missionary funds, and treating others nicely. The section included Bible games whereby children were instructed to search the Bible for clues in specific locations and mail in their answers for prizes. As Mary's letter indicates, it also served to connect Pentecostal children internationally.

Pentecostal youth were another group that the magazine specifically targeted. Beginning in the 1930s the editors allowed The Young People's Union (Y.P.U.) to print their own mini-publication called The Pentecostal Link [Die Pinkster Skakel] within The Comforter. When the Y.P.U. first organized in 1916, it was mainly in order to provide a space for the youth of Johannesburg to socialize and work together in service projects. ${ }^{87}$ They formally organized on April 7th, 1919 with the initial task of collecting money to send to missionaries in the field. ${ }^{88}$ They organized their first conference in 1930. The Comforter printed occasional reports of the group over the years, and The Pentecostal Link served as a monthly newsletter for South African AFM youth.

The readers in South Africa were increasingly exposed to a more cosmopolitan Pentecostalism than they had been previously. In addition to creating more diversified sections, the magazine moved beyond the confines of the local and the institutional by incorporating assorted teachings and contributors. Many famous evangelists and preachers published articles in The

\footnotetext{
87 The Comforter, June 1916, 7.

88 Our Pentecostal Youth Annual 1943, reprinted in Isak Burger and M. Nel, Apostolic Faith Mission of South Africa 1908-2008. Centurion: Apostolic Faith Mission of South Africa, 2008. 78.
} 
Comforter on topics of spiritual interest. At one point the editors included a four page article from A.C. Dixon entitled "Spiritualism: Is it of God or of the Devil?"89 Articles like these reveal an important element of the Pentecostal print networks, for they exposed readers to theological debates surging in other places in the world. Dixon was a Baptist and an editor of The Fundamentals, a set of 90 essays published during 1910-1915 that became the foundational texts for modern Christian fundamentalism. ${ }^{90}$ The influence of American evangelical thought and culture increasingly seeped into the magazine's messaging as well. Articles ranged from debating the morality of motion pictures to the importance of Sunday Schools filled the pages of The Comforter. ${ }^{91}$ A quip in the bottom corner of a 1947 issue quoted an American Presbyterian minister: "Thousands of men are in hell, whose eternal damnation is due to the improper dress of women." 92 In May 1948 the editors began including a small notice under the contact information, stating "The Apostolic Faith Mission does not necessarily associate itself with the doctrinal viewpoints of contributors to this magazine."93 Such statements indicate a desire to appeal to "mainline" Christianity, while retaining a core Pentecostal identity.

\footnotetext{
89 The Comforter, August 1921, 9-12.

${ }^{90}$ In his article, Dixon expounded on the subject of spiritualism, concluding that while the spiritual world was very much real, Christians should not seek spirits out, whether good or evil ones. The Comforter, August 1921, 9-12.

91 The Comforter-Trooster, April 1939, 27; The Comforter-Trooster, June 1938, 14.

92 Thomas De Witt Talmage, The Comforter-Trooster, May 1947, 21.

${ }^{93}$ Original in Afrikaans: "Die Apostoliese Geloof Sending vereenselwig hulle nie noodwendig met die leerstellige standpunt van skrywers in die blad nie." The Comforter-Trooster, May 1948, 2.
} 
Its increasingly cosmopolitan scope pushed the editors beyond topics of morality, theology, and institutional concerns. During the 1940s, The Comforter also spoke out about many of the pressing social and political issues of the time. A 1948 issue featured a several-page article warning of the rise of communism, and the false promises of its Utopian end. More critically, the author chose to equate the values of democracy and Christianity, saying:

It is well to remember the democratic aspect of Christianity...The more the Scriptures are studied, the more obvious it becomes that true religion of Christ is the perfect expression of the highest ideals of democracy. Everything that is opposed to democratic ideals is in spirit, if not in fact, opposed to Christianity. The principle of Christianity is that all are equal and that merit alone is the criterion of a man. That is true democracy. The ideal of democracy is that every man shall live not for himself but for all his fellow-men, and will exert his talents and capabilities to the utmost for the common welfare of mankind. That Is both Christianity and Democracy. ${ }^{94}$

While an anti-communist position would be expected of a magazine produced by Afrikaners editors, this particular emphasis on democratic values reveals The Comforter's disconnect with racial issues in South Africa in 1948.

This network of print fostered relationships between Pentecostals living worlds apart, and provided local Pentecostals access to a world of Pentecostal movements. Letters and testimonies continued to be published from foreign countries, increasingly from South African Pentecostals who had emigrated. The greatest influence came from America. Du Plessis' 1937 trip to the U.S. reveals the impact of these connections. Having associated with Du Plessis through correspondence related to The Comforter, J. Roswell Flower, the General

94 The Comforter-Trooster, November 1948, 22. 
Secretary of the American Assemblies of God, invited Du Plessis to speak at the denomination's general council in Memphis, TN. ${ }^{95}$ Once in America, Du Plessis was shocked to find out that whites and blacks worshiped together at campground meetings. ${ }^{96} \mathrm{He}$ took this experience back with him to South Africa and after much negotiation with the Executive Council, he began organizing camp meetings that turned out to be highly popular, photos of which fill the pages of many of the late 1930 and 1940s papers. ${ }^{97}$ In 1944 the Johannesburg Star published a letter to the editor from a subscriber, saying:

Sir, for some time past my attention has been drawn to the beneficent and unobtrusive work the Apostolic Faith Mission of South Africa are doing in the cause of racial peace, and although I am not a member of that body, I am glad to be able to confirm their laudable efforts. In these unsettled times anything that tends to foster better relations and the spread of the gospel should be hailed with satisfaction and developed as much as possible. Racial cleavage I might add is entirely absent among the large mission congregations comprising English and Afrikaans-speaking citizens. Their services are conducted in both languages each in turn being interpreted, which I consider as fine a gesture in promoting amity and good will as one could wish for. The friendliness and understanding between the races in this great mission are having an amazing good effect. A tribute of the highest order is due to the pastors and leaders for their praiseworthy achievements. A further gratifying feature is the manner the young people and juvenile members emulate the inspiring example of their elders. Their ability to recite scripture, and sing in each other's language is impressive and instructive. ${ }^{98}$

While this by no means speaks for all interactions between the races within the framework of the AFM, it suggests that there may have been more interaction

\footnotetext{
95 Du Plessis and Slosser, A Man Called Mr. Pentecost, 91.

96 lbid, 108.

${ }^{97}$ Stanley M. Burgess and Ed M. Van der Maas, The New International Dictionary of Pentecostal and Charismatic Movements. (Grand Rapids, Mich: Zondervan Pub. House, 2002), 590.

98 The Star, May 5th, 1944. Apostolic Faith Mission Archives.
} 
than previously thought. In particular, the popularity of the camp meeting reflected a return to the exuberant revivalism of the early years.

Finally, The Comforter took on an increasingly global scope towards the mid-twentieth century. The number of articles from other Pentecostal magazines republished in The Comforter increased, particularly those from the United States such as The Pentecostal Evangel, Glad Tidings, and Word and Work. They also frequently included articles from evangelical but non-Pentecostal sources such as The Evangelical Beacon. ${ }^{99}$ Denominational disputes and differences were conspicuously absent, as the editors chose to instead craft a narrative of unity and progress. Reports in the aftermath of WWII announced revivals in cities from Paris to Tsingtao. An article entitled "Religious Dynamite," emphasized the global spread of the movement:

According to a report in the Religious News Service (an American publication), church leaders are growing concerned over the rapid growth of the "emotional" or Pentecostal sects, as they call us. One man referred to these sects as "religious dynamite," and he emphasised [sic] that the problem has long since passed the "launching off" stage. Worst of all, it was observed, the war is causing Pentecostal believers to be scattered abroad, and wherever they go they seem to be spreading their beliefs! 100

The post-War years indeed proved to be a catalyst for yet another global wave of Pentecostalism. By focusing on the international community of Pentecostal believers, the editors of The Comforter ignored the growing socio-political problems at home. The editors erased racial tensions within the AFM and country

\footnotetext{
99 The Comforter-Trooster, December 1938, 30.

100 The Comforter-Trooster, September 1944, 19.
} 
by framing the focus of The Comforter on the growing network of Pentecostals worldwide.

The transformation and growth of The Comforter during this period reveals the interconnectedness of the developing Pentecostal movement. Print networks replaced much of the traditional institutional structures necessary for development. Print culture supplemented a culture of oral tradition on the local level, and expanded it globally. Pentecostals from diverse backgrounds participated in this textually defined global community, thereby helping to mold a common Pentecostal identity centered on the belief of the primacy of the Holy Spirit in the believer's life. Through engagement with their spiritual brethren around the world through this 'pneuma' network, Pentecostals used the printed word to transform their world. 


\section{CHAPTER 8: EPILOGUE}

Although the original Azusa Street Mission ceased to exist in 1931 when the remaining congregation lost the building, the spirit of the revival lived on in Pentecostal denominations like the Apostolic Faith Mission of South Africa. American Pentecostalism grew steadily out from Azusa, splitting into denominations within a matter of decades. By mid-century some of the biggest Pentecostal denominations like the Assemblies of God, Church of God in Christ, the Church of God (Cleveland, TN), and the International Church of the Foursquare Gospel were established and planting assemblies throughout the world. Although divided by race and doctrine, individuals within the disparate camps nonetheless communicated and forged relationships with other Pentecostals around the world through a vast network of Pentecostal print media. Pentecostal periodicals served as an indispensable vehicle for their evangelistic efforts and growth. Transnational in nature, this network encouraged believers to think about themselves as part of a global religious movement.

By the late 1940s the Apostolic Faith mission of South Africa had emerged as a leader within this global Pentecostal network, as demonstrated at the first Pentecostal World Conference in Zurich in $1947 .{ }^{1}$ Du Plessis resigned his position as General Secretary of the AFM in the fall of 1947 in order to help organize the event. The goal of the conference was to gather together representatives from Pentecostal assemblies around the world to promote

\footnotetext{
${ }^{1}$ Cecil M. Robeck and Amos Yong. The Cambridge Companion to Pentecostalism. (New York: Cambridge University Press, 2014). 279.
} 
Christian fellowship and cooperation amongst Pentecostals worldwide. ${ }^{2}$ Three thousand members from Pentecostal churches in 23 countries attended. ${ }^{3}$

Despite lingering animosities amongst attendees from rival countries and even denominations, the conference was successful in bringing together the Pentecostal diaspora for the first time in the movement's history. The Comforter covered the conference extensively due to Du Plessis's involvement as one of the chief organizers, and his position as the keynote speaker. ${ }^{4}$ Sermons from the ministers at the conference were reprinted for months. One sermon in particular by Fred H Squire, President of the Full Gospel Testimony expounded:

The world has passed through the worst war in history; the world is in a desperate condition, and we are here in Zurich to-day as a Pentecostal Movement, praying that something will be done, but it is not enough to talk, something has to be accomplished. We know that the suffering people need money; they need food and clothing, but I believe this sin sick world needs more than that; I believe it needs a man; the Man, Christ Jesus... Many men have tried to win this world right through history. It has happened in our own lifetime, for at least two men have tried to win the world by force, and, we have been plunged into darkness through the selfishness of some, but one thing has been provd: force can never win the world. Everyone who has tried, has failed, but whilst the greatest soldiers have failed and whilst emperors have failed, yet there comes One Whose name is Jesus, the despised and rejected One, the carpenter's Son, and He says: 'If I be lifted up, I will draw all men unto me. ${ }^{5}$

\footnotetext{
2 "Pentecostal World Fellowship: 24 $4^{\text {th }}$ Pentecostal World Conference," accessed March 3, 2016. http://24pwc.org/site/institutional. As Du Plessis recounts, this was no easy feat to organize, as many Pentecostals wrote to the organizers asking for special accommodations in order to avoid certain groups. Du Plessis wrote "It got so bad that a group from one country would send spies to determine where another party from the same country was sitting at the conference, and then the first party would arrange to sit on the opposite side of the hall." Du Plessis and Slosser, 114.

3 "Pentecostal World Fellowship: Who We Are," accessed March 3, 2016. http://24pwc.org/site/conference.

${ }^{4}$ David Du Plessis and Bob Slosser. A Man Called Mr. Pentecost, 115.

5 "The Uplifted Christ," The Comforter-Trooster, February 1948, 6.
} 
This sermon reaffirmed Pentecostalism as a movement and pushed for a renewed focus on global evangelization in the aftermath of WWII. After such a devastating war, it was important to members that they focus on unifying the movement once again

One of the main goals of the conference was to unify the global movement by bringing Pentecostals from vastly different backgrounds into constructive dialogue. It appears from the accounts of the participants that they succeeded. ${ }^{6}$ Donald Gee, an English Pentecostal author and frequent contributor to The Comforter, wrote of the spirit of unity at the conference, saying:

'Zurich' was made possible because of what God hath wrought already: the further potentialities are immense. Our eyes are on the big things that unite, not on the smaller issues that divide... Within the Pentecostal Revival itself, a profound, and indeed unique, unity of the Spirit has been given to us by Christ Jesus: it leaves nothing for us to 'make', but much that we must zealously endeavor to 'keep'. The burning heart of

Pentecostal Fellowship is not an idea, nor a form of government; nor even a 'vision', but a BAPTISM - in the Holy Ghost and Fire. ${ }^{7}$

This idea of unity through the Spirit of God became a rallying point for the Pentecostals as they sought to return to reignite the movement in the post-war years. The Zurich conference was followed by a second conference in Paris in 1949, and subsequently they were held every three years. These conferences

\footnotetext{
${ }^{6}$ Jean-Daniel Pluess, "One in the Spirit? Pentecostals and the Yearning for Christian Unity: A Case Study of the Swiss Pentecostal Mission and Its Initiatives Towards Unity in the Spirit" in John Gibaut and Knud Jorgensen, Called to Unity: For the Sake of Mission, (Eugene, OR: Wipf and Stock Publishers, 2014), 178.

7 Pentecost, September 1947, 2. (capitals in original text). Cited in Jean-Daniel Pluess, "One in the Spirit? Pentecostals and the Yearning for Christian Unity: A Case Study of the Swiss Pentecostal Mission and Its Initiatives Towards Unity in the Spirit" in John Gibaut and Knud Jorgensen, Called to Unity: For the Sake of Mission, 178.
} 
helped to expand the growing international network of Pentecostals, and led to the formation of the Pentecostal World Fellowship, a global cooperative body of Pentecostals. ${ }^{8}$

One of the greatest legacies of the conference was the creation of a world Pentecostal paper entitled simply, Pentecost. Donald Gee served as managing editor of Pentecost until his death in 1966. The paper served as the major organ of the movement, encouraging ecumenical conversations from Pentecostals around the world, and delivering news of the movement to its readers. ${ }^{9}$ The Comforter heavily advertised the Pentecost in the wake of the Zurich Conference. "You can now order your copy of the New World Pentecostal Magazine," read the ad. The ad claimed it was a "beautifully produced and illustrated paper" containing "valuable Missionary and Revival News from all over the World in all sections of the Pentecostal Movement."10

By the time of the Zurich conference, the Apostolic Faith Mission was a major Pentecostal mission within a global movement positioned to take full advantage of the post-WWII surge in evangelical missions. In the post-war years, the mission experienced tremendous growth. By 1996, the South African government census reported that the mission had over one million members. ${ }^{11}$

\footnotetext{
8 Wolfgang Vondey, "Pentecostalism and Ecumenism" in Robeck Jr., Cecil M., and Amos Yong. The Cambridge Companion to Pentecostalism. (Cambridge: Cambridge University Press, 2014), 279.

${ }^{9}$ Ibid, 280.

10 The Comforter-Trooster, June 1948, 24.

${ }^{11}$ Frank Chikane, "The Blessings of Azusa Street and Doornfontein Revivals and Pentecost's Blind Spot," in Hunter, Harold D., and Cecil M. Robeck. The Azusa Street Revival and Its Legacy.
} 
The mission reunified its separate ethnic branches after the 1994 elections in South Africa. As one of the leading mainstream Pentecostal denominations, the AFM went on to establish missions in fifteen countries on the African continent, as well as in India, Pakistan, Belgium, Britain, Brazil, and Dallas, U.S.A., bringing the message of Pentecost full circle back to the country of its birth. ${ }^{12}$

(Cleveland, TN: Pathway Press, 2006), 262.

${ }^{12}$ Isak Burger, The Fire Falls in Africa, 468. 


\section{BIBLIOGRAPHY}

Adhikari, Mohamed. "Contending Approaches to Coloured Identity and the History of the Coloured People of South Africa". History Compass. 3, no. 1 (2005) doi: 10.1111/j.1478-0542.2005.00177.x.

Afolayan, Funso. Culture and Customs of South Africa. Westport, Conn: Greenwood Press, 2004.

Ahlstrom, Sydney, A Religious History of the American People. New Haven and London: Yale University Press, 1972.

Aiken, Charles S. The Cotton Plantation South Since the Civil War. Baltimore: Johns Hopkins University Press, 1998.

Alexander, Estrelda. Black Fire: One Hundred Years of African American Pentecostalism. Downers Grove, IL: InterVarsity Press, 2011.

Alexander, Estrelda. The Women of Azusa Street. Cleveland, Ohio: Pilgrim Press, 2005.

Alexander, Paul, and Stanley Hauerwas. Pentecostals and Nonviolence: Reclaiming a Heritage. Eugene, Oregon: Pickwick Publications 2012.

Anderson, Allan H. An Introduction to Pentecostalism: Global Charismatic Christianity. Cambridge: Cambridge University Press, 2004.

Anderson, Allan H. African Reformation: African Initiated Christianity in the 20th Century. Trenton, NJ: Africa World Press, Inc., 2001.

Anderson, Allan H. Bazalwane: African Pentecostals in South Africa. Pretoria: University of South Africa, 1992.

Anderson, Allan H.. "Exorcism and Conversion to African Pentecostalism". Exchange: Bulletin De Littérature Des Églises Du Tiers Monde. 35, no. 1 (2006): 116-133.

Anderson, Allan H. "New African Initiated Pentecostalism and Charismatics in South Africa" Journal of Religion in Africa 35, no. 1 (2005): 66-92.

Anderson, Allan H. "Pentecostals and Apartheid in South Africa during Ninety Years 1908-1998." Cyberjournal for Pentecostal-Charismatic Research, 
2000. Accessed March $12^{\text {th }}, 2016$.

http://www.pctii.org/cyberj/cyberj9/anderson.html

Anderson, Allan H. Spreading Fires: the Missionary Nature of Early

Pentecostalism. Maryknoll, NY: Orbis Books, 2007.

Anderson, Allan H. Studying Global Pentecostalism: Theories and Methods.

Berkeley: University of California Press, 2010.

Anderson, Allan $\mathrm{H}$. "The Lekganyanes and Prophecy in the Zion Christian Church" Journal of Religion in Africa 29, no. 3 (1999) 285-312.

Anderson, Allen $\mathrm{H}$., To the Ends of the Earth: Pentecostalism and the Transformation of World Christianity, New York, NY: Oxford University Press, 2013.

Anderson, Allan H., and Walter J. Hollenweger (eds.) Pentecostal after a Century. JPTS 15. Sheffield, Sheffield Academic Press, 1999.

Anderson, Allan H., and Samuel Otwang, Tumelo: The Faith of African

Pentecostals in South Africa. Pretoria: University of South Africa, 1993.

Anderson, Benedict. Imagined Communities: Reflections on the Origin and Spread of Nationalism. London: Verso, 2006.

Anderson, Robert Mapes. Vision of the Disinherited: The Making of American Pentecostalism. New York, NY: Oxford University Press, 1979.

Andrews, Edward E. Native Apostles: Black and Indian Missionaries in the British Atlantic World. Cambridge, Mass: Harvard University Press, 2013.

Apostolic Faith Mission (Portland, OR). A Historical Account of the Apostolic Faith, A Trinitarian-Fundamental Evangelistic Organization: Its Origin, Functions, Doctrinal Heritage, and Departmental Activities of Evangelism. Portland, OR: Apostolic Faith Pub. House, 1965.

Applegate, Debby. The Most Famous Man in America: The Biography of Henry Ward Beecher. New York: Doubleday, 2006.

Archer, Melissa L. "The Worship Scenes in the Apocalypse, Effective History, and Early Pentecostal Periodical Literature," Journal of Pentecostal Theology 21 (2012) 87-112. 
Arrington, Leonard J., and Davis Bitton, The Mormon Experience: A History of the Latter-Day Saints. New York: Knopf, 1979.

Ashforth, Adam. Witchcraft, Violence, and Democracy in South Africa. Chicago: University of Chicago Press, 2005.

Bailey, Julius. Race Patriotism: Protest and Print Culture in the AME Church. Knoxville: University of Tennessee Press. 2012

Balmer, Randall. The Making of Evangelicalism: From Revivalism to Politics and Beyond. Waco, TX: Baylor University Press, 2010.

Barfoot, Chas H. Aimee Semple Mcpherson and the Making of Modern Pentecostalism, 1890-1926. London: Equinox, 2011.

Barnes, Kenneth C. 2002. "'On the Shore Beyond the Sea": Black Missionaries from Arkansas in Africa During the 1890s". The Arkansas Historical Quarterly. 61, no. 4: 329-356.

Barrios, Olga. The Black Theatre Movement in the United States and in South Africa. València: Universitat de València, 2008.

Beaman, Jay. Pentecostal Pacifism: The Origin, Development, and Rejection of Pacific Belief Among Pentcostals. Hillsboro, KS: Center for Mennonite Brethren Studies, 1989.

Beaman, Jay, and Brian K. Pipkin, Pentecostal and Holiness Statements on War and Peace. Eugene, Oregon: Pickwick Publications, 2013.

Bebbington, D. W. Holiness in Nineteenth-Century England. Carlisle:

Paternoster, 2000.

Becken, H.-J., "A Healing Church in Zululand: "the New Church Step To Jesus Christ Zion in South Africa" Journal of Religion in Africa, 1972, vol. 4, no. 3, pp. 213-222 (10).

Becken, H.-J., "On the Holy Mountain: a Visit To the New Year's Festival of the Nazaretha Church On Mount Nhlangakazi, 14 January, 1967" Journal of Religion in Africa, 1967, vol. 1, no. 2, pp. 138-149 (12).

Beckford, James A. The Trumpet of Prophecy: A Sociological Study of Jehovah's Witnesses. New York: Wiley, 1975. 
Bediako, Kwame. Jesus and the Gospel in Africa: History and Experience. New York, NY: Orbis Books, 2004.

Bedwell, H. Kenneth. Black Gold. The Story of the International Holiness Mission in South Africa. 1908-1936. Cape Times: Cape Town, 1938.

Beinart, William. Twentieth-Century South Africa. Oxford: Oxford University Press, 2001.

Beinart, William, and Saul Dubow. Segregation and Apartheid in TwentiethCentury South Africa. London: Routledge, 1995.

Berglund, Axel-Ivar "The Zulu Prophet Laduma Madela" Journal of Religion in Africa, 2000, vol. 30, no. 3, pp. 386-393 (8).

Bergunder, Michael, A. F. Droogers, Cornelis van der Laan, Cecil M. Robeck, and Allan Anderson. Studying Global Pentecostalism: Theories and Methods. Berkeley, CA: University of California Press, 2010.

Bergunder, Michael. The South Indian Pentecostal Movement in the Twentieth Century. Grand Rapids, MI: William B. Eerdmans Pub. Co, 2008.

Billingsley, Scott. It's a New Day: Race and Gender in the Modern Charismatic Movement. Tuscaloosa, Ala: University of Alabama Press, 2008.

Blake, Curry R. John G. Lake's Writings From Africa, USA: Xulon Press, 2005.

Bliss, Michael. William Osler: A Life in Medicine. New York: Oxford University Press, 2007.

Block-Hoell, Nils. The Pentecostal Movement: Its Origin, Development, and Distinctive Character. Oslo: Universitetsforlaget; London: Allen and Unwin; and New York: Humanities Press, 1964.

Blumhofer, Edith L. "The 'Overcoming Life': A Study in the Reformed Evangelical Origins of Pentecostalism." Ph.D. diss., Harvard University, 1977.

Blumhofer, Edith L. Restoring the Faith: The Assemblies of God, Pentecostalism, and American Culture. Urbana, University of Illinois Press, 1993.

Blumhofer, Edith L. The Assemblies of God: A Chapter in the Story of American Pentecostalism. Springfield, Gospel Publishing House, 1989.

Blumhofer, Edith Waldvogel, Russell P. Spittler, and Grant Wacker. Pentecostal Currents in American Protestantism / edited by Edith L. Blumhofer, 
Russell P. Spittler, and Grant A. Wacker. Urbana: University of Illinois Press, 1999.

Bompani, Barbara "Religion and Development from Below: Independent Christianity in South Africa" Journal of Religion in Africa 40, no. 3 (2010): 307-330.

Bonnefoy, Yves, and Wendy Doniger. Mythologies. Chicago: University of Chicago Press, 1991.

Borer, Tristan Anne, Challenging the State: Churches as Political Actors in South Africa, 1980-1994. Notre Dame, IN: University of Notre Dame Press, 1998.

Borlase, Craig. William Seymour: a Biography. Lake Mary, FL: Chrarisma House, 2006.

Boyer, Paul S. When Time Shall Be No More: Prophecy Belief in Modern American Culture. Cambridge, Mass: Belknap Press of Harvard University Press, 1992.

Boyer, Paul S., and Charles Lloyd Cohen. Religion and the Culture of Print in Modern America. Madison, WI: Univ. of Wisconsin Press, 2008.

Breckenridge, K. 'Love Letters and Amanuenses: Beginning the Cultural History of the Working Class Private Sphere in Southern Africa, 1900-1933' Journal of Southern African Studies 26 (2000), pp. 337-348.

Brereton, Virginia Lieson, Training God's Army: The American Bible School, 1880-1940, Bloomington and Indianapolis, IN: Indiana University Press, 1990.

Brooks, Pamela E. Boycotts, Buses, and Passes: Black Women's Resistance in the U.S. South and South Africa. Amherst: University of Massachusetts Press, 2008.

Brown, Candy Gunther. The Word in the World: Evangelical Writing, Publishing, and Reading in America, 1789-1880. Chapel Hill: University of North Carolina Press, 2004.

Brown, W. E. The Catholic Church in South Africa, From its Origin to the Present Day. London: Burn \& Oats, 1960. 
Brumback, Carl. Suddenly ... From Heaven: a History of the Assemblies of God. Springfield, Mo: Gospel Pub. House, 1961.

Brumberg, Joan Jacobs. Mission for Life: The Story of the Family of Adoniram Judson, the Dramatic Events of the First American Foreign Mission, and the Course of Evangelical Religion in the Nineteenth Century. New York: Free Press, 1980.

Bull, Malcolm, and Keith Lockhart. Seeking a Sanctuary: Seventh-Day Adventism and the American Dream. Bloomington: Indiana University Press, 2007.

Burger, Isak, and Marius Nel. The Fire Falls in Africa: A History of the Apostolic Faith Mission in South Africa : a Centennial Edition 1908-2008. Vereniging: Christian Art Publishers, 2008.

Burgess, Stanley M., and Ed M. Van der Maas, The New International Dictionary of Pentecostal and Charismatic Movements. Grand Rapids, Mich: Zondervan Pub. House, 2002.

Burpeau, Kemp Pendleton God's Showman: A Historical Study of John G. Lake and South African/American Pentecostalism, Oslo, Norway: Refleks Publishing, 2004.

Burger, Isak. "The Apostolic Faith Mission of South Africa: An Introduction," Accessed April 1st, 2016. http://www.afm-ags.org/introduction.

Bushman, Richard L., and Jed Woodworth. Joseph Smith: Rough Stone Rolling. New York: Alfred A. Knopf, 2005.

Butler, Jonathan M. "Prophecy, Gender, and Culture: Ellen Gould Harmon [White] and the Roots of Seventh-Day Adventism". Religion and American Culture 1, no. 1 (1991): 3-29.

Calhoun, Charles W. The Gilded Age: Perspectives on the Origins of Modern America. Lanham, MA: Rowman \& Littlefield Publishers, 2007.

California Department of Finance. "Historical Census Populations of Counties and Incorporated Cities in California, 1850-2010," 2013, accessed April $9^{\text {th }}, 2016$.

http://www.dof.ca.gov/research/demographic/state_census_data_center/hi storical_census_1850-2010/view.php. 
Campbell, David E., John Clifford Green, and J. Quin Monson. Seeking the Promised Land: Mormons and American Politics. New York: Cambridge University Press, 2014.

Campbell, James T. Songs of Zion: the African Methodist Episcopal Church in the United States and South Africa. New York: Oxford University Press, 1995.

Carpenter, Joel A. Revive us Again: The Reawakening of American Fundamentalism. New York, NY: Oxford University Press, 1997.

Carroll, Henry K. Report on the Statistics of Churches in the U.S. in the Eleventh Census: 1890. Vol. IX. Eleventh Census: 1890. Washington, D.C.: Government Printing Office, 1894.

Cell, John Whitson. The Highest Stage of White Supremacy: The Origins of Segregation in South Africa and the American South. Cambridge: Cambridge University Press, 1982.

Cerillo, Augustus "The Origins of American Pentecostalism". Pneuma 15, no. 1 (1993): 77-88.

Chandomba, Lyton. The History of the Apostolic Faith Missions and other Pentecostal Missions in South Africa. Bloomington, IN: AuthorHouse, 2007.

Chappell, David L. A Stone of Hope: Prophetic Religion and the Death of Jim Crow. Chapel Hill: University of North Carolina Press, 2004.

Cheek, James. Footprints of a Human Life: An Autobiographical Sketch of the Life of James Cheek. Los Angeles, CA: Christ Faith Mission, Inc. 1949.

Chidester, David, Judy Tobler, and Darrel Wratten, Christianity in South Africa: an Annotated Bibliography. Bibliographies and indexes in religious studies, no. 43. Westport, Conn: Greenwood Press, 1997.

Chidester, David, Savage Systems: Colonialism and Comparative Religion in Southern Africa. Charlottesville, VA: University Press of Virginia, 1996.

Chikane, Frank. "The Blessings of Azusa Street and Doornfontein Revivals and Pentecost's Blind Spot" in Harold D. Hunter and Cecil M. Robeck, The Azusa Street Revival and Its Legacy. Cleveland, TN: Pathway Press, 2006. 
Chitando, Ezra "Wandering a Gendered Wilderness: Suffering and Healing in an African Initiated Church" Journal of Religion in Africa 38, no. 3 (September 2008): 343-344.

Clark, Matthew. "Mission Effort in the Apostolic Faith Mission of South Africa," Transformation: An International Journal of Holistic Mission Studies 26, no. 3 (2009): 174-185.

Clark, Matthew S. "Two Contrasting Models of Missions in South Africa: The Apostolic Faith Mission and the Assemblies of God," Asian Journal of Pentecostal Studies vol. 8, no. 1 (2005).

Clarke, Clifton R. Pentecostal Theology in Africa. Eugene, OR: Pickwick Publications, 2014.

Clendenen, Clarence C., Robert O. Collins, and Peter Duignan. Americans in Africa, 1865-1900. Stanford, CA: Hoover Institution on War, Revolution, and Peace, Stanford University, 1966.

Cobbing, Julian. "The Mfecane As Alibi: Thoughts on Dithakong and Mbolompo". The Journal of African History 29, no. 3 (1988).

Cochrane, James R. Servants of Power: The Role of English-Speaking Churches in South Africa, 1903-1930: Toward a Critical Theology Via an Historical Analysis of the Anglican and Methodist Churches. Johannesburg: Ravan Press, 1987.

Cochrane, James R. The Church and Labour in South Africa. Johannesburg: Skotaville Publishers, 1988.

Cochrane, James R., Servants of Power: The Role of the English-Speaking Churches in South Africa: 1903-1930, Johannesburg, South Africa: Ravan Press, 1987.

Comaroff, Jean, and John L. Comaroff, Of Revelation and Revolution: The Dialectics of Modernity on a South African Frontier V.I\&II. Chicago, IL: University of Chicago Press, 1991.

Comaroff, Jean, Body of Power, Spirit of Resistance: the Culture and History of a South African People. Chicago, IL: University of Chicago Press, 1985.

Comaroff, Jean. "Missionaries and Mechanical Clocks: An Essay on Religion and History in South Africa". The Journal of Religion. 71, no. 1 (1991): 1-17. 
Conkin, Paul Keith. When All the Gods Trembled: Darwinism, Scopes, and American Intellectuals. Lanham, MA: Rowman \& Littlefield Publishers, 1998.

Connelley, William Elsey. History of Kansas State and People: Kansas at the First Quarter Post of the Century. Chicago: American Historical Society, 1928.

Cook, Philip L. Zion City, Illinois: Twentieth Century Utopia. Syracuse, NY: Syracuse University Press, 1996.

Cooper, Valarie. "Laying the Foundations of Azusa: Black Women and Public Ministry in the Nineteenth Century." In Yong, Amos, and Estrelda Y. Alexander, eds. Afro-Pentecostalism: Black Pentecostal and Charismatic Christianity in History and Culture. New York: NYU Press, 2012.

Coplan, David B. In Township Tonight!: Three Centuries of South African Black City Music and Theatre. Auckland Park, South Africa: Jacana Media, 2007.

Corrigan, John. Business of the Heart: Religion and Emotion in the Nineteenth Century. Berkeley, CA: University of California Press, 2002.

Corten, André, and Ruth Marshall. Between Babel and Pentecost: Transnational Pentecostalism in Africa and Latin America. Bloomington: Indiana University Press, 2001.

Cox, Harvey. Fire From Heaven: The Rise of Pentecostal Spirituality and the Reshaping of Religion in the Twenty-first Century. Cambridge, MA: Da Capo Press, 1995.

Crais, Clifton C, The Politics of Evil: Magic, State Power, and the Political Imagination in South Africa. Cambridge, U.K.: Cambridge University Press, 2002.

Crais, Clifton C. White Supremacy and Black Resistance in Pre-Industrial South Africa: The Making of the Colonial Order in the Eastern Cape, 1770-1865. Cambridge, England: Cambridge University Press, 1992.

Crapanzano, Vincent, Serving the Word: Literalism in America from the Pulpit to the Bench, New York, NY: The New Press, 2000.

Creech, Joe. Righteous Indignation: Religion and the Populist Revolution. Urbana: University of Illinois Press, 2006. 
Creech, Joe. "Visions of Glory: The Place of the Azusa Street Revival in Pentecostal History," Church History 65 (1996), 405-424.

Crews, Mickey. The Church of God: a Social History. Knoxville: University of Tennessee Press, 1990.

Crompton, Cathy, and Audrey Ryan. God in Action: Revival in South Africa. Port Elizabeth, South Africa: Crompton Ministries, 1994.

Culpepper, Robert H. Evaluating the Charismatic Movement: A Theological and Biblical Appraisal. Valley Forge: Judson, 1977.

Cummergen, Paul "Zionism and Politics in Swaziland" Journal of Religion in Africa 30, no. 3 (2000): 370-385.

Cunningham, Raymond J. "From Holiness to Healing: The Faith Cure in America 1872-1892". Church History. 43, no. 4. (1974).

Cuthbertson, Greg. "Preaching Imperialism: Wesleyan Methodism and the War", published in The Impact of the South African War, David Omissi and Andrew Thompson (Ed.) New York: Palgrave, 2002.

Cuthbertson, Greg. "Pricking the 'Non-Conformist Conscience': Religion Against the South African War", published in The South African War Reappraised, Donal Lowry (Ed.). Manchester, UK: Manchester University Press, 2002.

Czegledy, Andre P. "A New Christianity for a New South Africa: Charismatic Christians and the Post-Apartheid Order" Journal of Religion in Africa 38, no. 3 (2008): 284-311.

Dachs, Anthony J. "Missionary Imperialism - the Case of Bechuanaland". The Journal of African History 13, no. 4 (1972): 647-658.

Daniels, David D. "Dialogue Between Black and Hispanic Pentecostal Scholars: A Report and Some Personal Reflections". Pneuma. 17, no. 1 (1995): 219-228.

Danky, James, Wayne Wiegand, and Elizabeth Long, eds., Women in Print: Essays on the Print Culture of American Women from the Nineteenth and Twentieth Centuries. Madison: University of Wisconsin Press, 2006.

Davenport, T. R. H., and Christopher C. Saunders. South Africa: A Modern History. Hampshire, England: Macmillan Press, 2000. 
Dayton, Donald W. "The Higher Christian Life": Sources for the Study of the Holiness, Pentecostal and Keswick Movements. New York: Garland Publishing, 1984-85.

Dayton, Donald W. "The Limits of Evangelicalism: The Pentecostal Tradition" in Dayton, Donald W., and Robert K. Johnston. The Variety of American Evangelicalism. Knoxville: University of Tennessee Press, 1991.

Dayton, Donald W. Theological Roots of Pentecostalism. Peabody, Henderickson, 1987.

Degler, Carl. At Odds: Women and the Family in America from the Revolution to the Present. New York: Oxford University Press, 1980.

De Gruchy, John W., Christianity and the Modernisation of South Africa: A Documentary History, Vol. 2, Hidden History Series, Pretoria: UNISA Press, 2009.

De Gruchy, John W., The Church Struggle in South Africa. Grand Rapids: W.B. Eerdmans Pub. Co., 1979.

De Gruchy, John W., The London Missionary Society in Southern Africa, 17991999. Athens, OH: Ohio University Press 2000.

de Leon, Victor. The Silent Pentecostals. Taylors, SC: Faith Printing Co., 1979.

Denis, Philippe. Orality, Memory, and the Past: listening to the voices of Black clergy under colonialism and Apartheid. Pietermaritzburg, South Africa: Cluster Publications, 2000.

De Wet, Christiaan Rudolph. The Apostolic Faith Mission in Africa, 1908-1980 A Case Study in Church Growth in a Segregated Society. PhD Diss., University of Cape Town, 1989.

Dilger, Hansjorg "Healing the Wounds of Modernity: Salvation, Community and Care in a Neo-Pentecostal Church in Dar Es Salaam, Tanzania" Journal of Religion in Africa 37, no. 1 (2007): 59-83.

Dillon-Malone, Clive, "The 'Mutumwa' Churches of Zambia: an Indigenous African Religious Healing Movement" Journal of Religion in Africa 14, no. 3 (1983): 204-222.

Dorsett, Lyle W. A Passion for Souls: The Life of D.L. Moody. Chicago: Moody Press, 1997. 
Du Bois, William Edward Burghardt. The Souls of Black Folk. Mineola, NY: Dover Publications, 1994.

Du Plessis, David, and Bob Slosser. 1977. A Man Called Mr. Pentecost. Plainfield, N.J.: Logos International, 1977.

Du Plessis, Johannes. A History of Christian Missions in South Africa. Cape Town: C. Struik, 1965.

Dusen, Henry P Van. "The Third Force in Christendom: Gospel-Singing, Doomsday-Preaching Sects Emerge as a Mighty Movement in World Religion" LIFE. June 9 $9^{\text {th }}, 1958$.

Du Toit, André. "No Chosen People: The Myth of the Calvinist Origins of Afrikaner Nationalism and Racial Ideology". The American Historical Review. 88, no. 4 (1983): 920-952.

Du Toit, André. "Puritans in Africa? Afrikaner "Calvinism" and Kuyperian NeoCalvinism in Late Nineteenth-Century South Africa". Comparative Studies in Society and History 27, no. 2 (1985): 209-240.

Dumenil, Lynn. The Modern Temper: American Culture and Society in the 1920 s. New York: Hill and Wang, 1995.

Edgar, Robert R., and Hillary Sapire. African Apocalypse: The Story of Nontetha Nkwenkwe, a Twentieth-Century South African Prophet. Johannesburg: Wits University Press, 1999.

Edmonds, Rick. "Christian Science Monitor sees traffic, revenues rising after 3 years of Web-first strategy" Poynter. May 2, 2012. Accessed November 12, 2015. http://www.poynter.org/2012/christian-science-monitor-seestraffic-revenues-rising-after-3-years-of-web-first-strategy/171833/

Egli, Martina, and Denise Krayer, Mothers and Daughters: The Training of African Nurses by Missionary Nurses of the Swiss Mission in South Africa. Lausanne: Le Fait Missionnaire, 1997.

Eisenstein, Elizabeth L. The Printing Press as an Agent of Change: Communications and Cultural Transformations in Early Modern Europe. Cambridge, UK: Cambridge University Press, 1979.

Elbourne, Elizabeth. Blood Ground: Colonialism, Missions, and the Contest for Christianity in the Cape Colony and Britain, 1799-1852. Montreal: McGillQueen's University Press, 2002. 
Ellis, Stephen, and Gerrie ter Haar, Worlds of Power: Religious Thought and Political Practice in Africa. Studies in contemporary history and world affairs, 1. New York: Oxford University Press, 2004.

Elphick, Richard, and T. R. H. Davenport. Christianity in South Africa: A Political, Social, and Cultural History. Berkeley, Calif: University of California Press, 1997.

Enklaar, Ido H. Life and Work of Dr J. Th. Van der Kemp 1747-1811. Cape Town: A. A. Balkema, 1988.

Erasmus, Lodewikus Johannes. Theological Education in the Apostolic Faith Mission of South Africa. PhD Dissertation, Pretoria: University of South Africa, 1997.

Erie, Steven P. Globalizing L.A.: Trade, Infrastructure, and Regional Development. Stanford: Stanford University Press, 2004.

Espinosa, Gastón. Borderland Religion: Los Angeles and the Origins of the Latino Pentecostal Movement in the U.S., Mexico, and Puerto Rico, 19001945. Ph.D. Dissertation. University of California, Santa Barbara, 1999.

Espinosa, Gastón. William J. Seymour and the Origins of Global Pentecostalism: A Biography and Documentary History. Durham and London: Duke University Press, 2014.

Evans, Ivan T. Cultures of Violence: Racial Violence and the Origins of Segregation in South Africa and the American South. Manchester, UK: Manchester University Press, 2011.

Fackler, P. Mark, and Charles H. Lippy, Popular Religious Magazines of the United States. Westport, CT: Greenwood Press, 1995.

Fasholé-Luke, Edward W. Christianity in Independent Africa. London: R. Collings, 1978.

Fast, Hildegarde H. "'In at One Ear and out at the Other': African Response to the Wesleyan Message in Xhosaland, 1825-1835." Journal of Religion in Africa 23 (1993). 147-174.

Faupel, D. William. The Everlasting Gospel: the Significance of Eschatology in the Development of Pentecostal Thought. JPTS 10. Sheffield, Sheffield Academic Press, 1996. 
Feinstein, C. H. An Economic History of South Africa: Conquest, Discrimination, and Development. New York: Cambridge University Press, 2005.

Feldman, Leybl, and Veronica Belling, The Jews of Johannesburg: (Until Union-31st May, 1910). Cape Town: Isaac and Jessie Kaplan Centre for Jewish Studies and Research, University of Cape Town, 2007.

Fields, Karen E., Revival and Rebellion in Colonial Central Africa. Princeton, N.J.: Princeton University Press, 1985.

Findlay Jr, J.F. Dwight L. Moody: American Evangelist 1837-1899. Chicago: University of Chicago Press, 1969.

Flexner, Eleanor. Century of Struggle: The Women's Rights Movement in the United States. Cambridge: Belknap Press, 1975.

Flint, Karen Elizabeth. Healing Traditions: African Medicine, Cultural Exchange, and Competition in South Africa, 1820-1948. Athens, Ohio: Ohio University Press, 2008.

Fogelson, Robert M. The Fragmented Metropolis: Los Angeles, 1850-1930. Berkeley: University of California Press, 1993.

Foster, Gaines M., Moral Reconstruction: Christian Lobbyists and the Federal Legislation of Morality, 1865-1920, Chapel Hill: The University of North Carolina Press, 2002.

Fredrickson, George M. Black Liberation: A Comparative History of Black Ideologies in the United States and South Africa. New York: Oxford University Press, 1996.

Fredrickson, George M. White Supremacy: A Comparative Study in American and South African History. New York: Oxford University Press, 1981.

Frey, Sylvia R., and Betty Wood, Come shouting to Zion: African American Protestantism in the American South and British Caribbean to 1830. Chapel Hill: University of North Carolina Press, 1998.

Frodsham, Stanley H. This Pentecostal Revival. Springfield, MO: Gospel Publishing House, 1941.

Ganiel, Gladys "Is the Multiracial Congregation an Answer to the Problem of Race? Comparative Perspectives from South Africa and the USA" Journal of Religion in Africa, September 2008, vol. 38, no. 3, pp. 263-283 (21). 
Johnathan N. Gerstner, "A Christian Monopoly: The Reformed Church and Colonial Society Under Dutch Rule" in Elphick and Davenport, Eds., Christianity in South Africa. Berkeley, Calif: University of California Press, 1997.

Gibellini, Rosino. Paths of African Theology. Maryknoll, NY: Orbis Books, 1994.

Gifford, Paul. Ghana's New Christianity: Pentecostalism in a Globalizing African Economy. Bloomington, IN: Indiana University Press, 2004.

Gifford, Paul, The New Crusaders: Christianity and the New Right in Southern Africa. Pluto Perspectives. London: Pluto Press, 1991.

Giliomee, Hermann Buhr. The Afrikaners: Biography of a People. Charlottesville, VA: University of Virginia Press, 2009.

Gitlin, Marcia. The Vision Amazing; The Story of South African Zionism. Johannesburg: Menorah Book Club, 1950.

Glaude, Eddie S. "Of the Black Church and the Making of a Black Public," in West, Cornel, and Eddie S. Glaude. African American Religious Thought: An Anthology. Louisville, KY: Westminster John Knox Press, 2003.

Goatley, David Emmanuel. Were you there?: Godforsakenness in Slave Religion. Bishop Henry McNeal Turner/Sojourner Truth series in Black religion, v. 11. Maryknoll, N.Y.: Orbis Books, 1996.

Goff, James R. Fields White Unto Harvest. Fayetteville, AK: University of Arkansas Press, 1988.

Goff, James R., Jr. "The Limits of Acculturation: Thomas Hampton Gourley and American Pentecostalism." Pneuma 18 (1996) 171-184.

Goff, James R., and Grant Wacker, Portraits of a Generation: Early Pentecostal Leaders. Fayetteville: University of Arkansas Press, 2002.

Goss, Ethel E. The Winds of God: The Story of the Early Pentecostal Movement (1901-1914) in the Life of Howard E. Goss. Hazelwood, MO: Word Aflame Press, 1958.

Gottschalk, Stephen. The Emergence of Christian Science in American Religious Life. Berkeley: University of California Press, 1973.Gray, Richard. Black Christians and White Missionaries. New Haven: Yale University Press, 1990. 
Gray, Richard. Black Christians and White Missionaries. New Haven: Yale University Press, 1990.

Graybill, Lyn S. Religion and Resistance Politics in South Africa. Westport, Conn: Praeger, 1995.

Greenwood, Janette Thomas. First Fruits of Freedom: The Migration of Former Slaves and Their Search for Equality in Worcester, Massachusetts, 18621900. University of North Carolina Press, 2009.

Grundlingh, A. M. Fighting Their Own War: South African Blacks and the First World War. Johannesburg: Ravan Press, 1987.

Gunner, Elizabeth. The Man of Heaven and the Beautiful Ones of God = Umuntu Wasezulwini Nabantu Abahle Bakankulunkulu : Writings from Ibandla LamaNazaretha, a South African Church. Boston: Brill, 2002.

Hall, Martin. Archaeology and the Modern World: Colonial Transcripts in South Africa and the Chesapeake. London: Routledge, 2000.

Hammond, Phillip E. 1983. "In Search of a Protestant Twentieth Century: American Religion and Power Since 1900". Review of Religious Research. 24, no. 4: 281-294.

Hammond-Tooke, W. D., and Isaac Schapera. The Bantu-Speaking Peoples of Southern Africa. London: Routledge \& K. Paul, 1974.

Hancock, W. K. Smuts. Vol.1, The Sanguine Years, 1870-1919. Cambridge: University Press, 1962.

Handy, Robert T. A Christian America: Protestant Hopes and Historical Realities. Oxford: Oxford University Press, 1984.

Hangen, Tona J. Redeeming the Dial: Radio, Religion, and Popular Culture in America. Chapel Hill: University of North Carolina Press, 2002.

Hardesty, Nancy. Faith Cure: Divine Healing in the Holiness and Pentecostal Movements. Peabody, MA: Hendrickson Publishers, 2003.

Harrell, David Edwin, Jr. All Things Are Possible: The Healing and Charismatic Revivals in Modern America. Bloomington: Indiana University Press, 1975.

Harrell, David Edwin, Jr. Oral Roberts: An American Life. Bloomington: Indiana University Press, 1985. 
Harries, Patrick. Butterflies and Barbarians: Swiss missionaries and systems of knowledge in South-East Africa. Oxford: James Currey, 2007.

Harries, Patrick. Work, Culture, and Identity: Migrant Laborers in Mozambique and South Africa, C.1860-1910. Portsmouth, NH: Heinemann, 1994.

Harries, Patrick, and David Maxwell, The Spiritual in the Secular: Missionaries and Knowledge About Africa. Grand Rapids, Mich: W.B. Eerdmans Pub. Co, 2012.

Harrison, Barbara Grizzuti. Visions of Glory: A History and a Memory of Jehovah's Witnesses. New York: Simon and Schuster, 1978.

Harvey, Paul. Freedom's Coming: Religious Culture and the Shaping of the South from the Civil War through the Civil Rights Era, Chapel Hill: The University of North Carolina Press, 2005.

Hatch, Nathan O. The Democratization of American Christianity. New Haven: Yale University Press, 1989.

Hatton, T. J., and Jeffrey G. Williamson. The Age of Mass Migration: Causes and Economic Impact. New York: Oxford University Press, 1998.

Hayford, Jack W., and S. David Moore, The Charismatic Century: The Enduring Impact of the Azusa Street Revival, New York: Time Warner Books Group, 2006.

Herrman, Louis. A History of the Jews in South Africa, from the Earliest Times to 1895. Westport, Conn: Greenwood Press, 1975.

Heuser, Andreas "'Africa Always Brings Us Something New': A Historiography of African Zionist and Pentecostal Christianities". Religion. 45 (2015): 153173.

Hewison, H. Hedge of Wild Almonds: South Africa, the Pro-Boers \& the Quaker Conscience, 1890-1910. Portsmouth: Heinemann, 1989.

Higgs, Catherine. The Ghost of Equality: the Public Lives of D.D.T. Jabavu of South Africa, 1885-1959. Athens, OH: Ohio University Press, 1997.

Hinchliff, Peter Bingham. The Church in South Africa. London: S.P.C.K. for the Church Historical Society, 1968. 
Hise, Greg. Magnetic Los Angeles: Planning the Twentieth-Century Metropolis. Baltimore: John Hopkins University Press, 1997.

Hofmeyr, Isabel. Gandhi's Printing Press: Experiments in Slow Reading. Cambridge, MA: Harvard Univ. Press, 2013.

Hofstadter, Richard. The Age of Reform: From Bryan to F.D.R. New York: Vintage Books, 1955.

Hollenweger, Walter J. The Pentecostals: The Charismatic Movement in the Churches. Minneapolis: Augsburg Publishing House, 1972.

Hopkins, Dwight N. Black Theology USA and South Africa: Politics, Culture, and Liberation. The Bishop Henry McNeal Turner studies in North American Black religion, vol. 4. Maryknoll, N.Y.: Orbis Books, 1989.

Hornsby, Alton. Black America: A State-by-State Historical Encyclopedia. Santa Barbara, CA: Greenwood, 2011.

Howe, Daniel Walker. What God Hath Wrought: The Transformation of America, 1815 - 1848. New York: Oxford University Press, 2007.

Hughes, Richard T., Ed. The Primitive Church in the Modern World. Urbana and Chicago: University of Illinois Press, 1995.

Hutchison, William R. The Modernist Impulse in American Protestantism. Cambridge, MA: Harvard University Press, 1976.

Ingram, Hilary. Gender, Professionalism and Power The Rise of the Single Female Medical Missionary in Britain and South Africa, 1875-1925. M.A. Thesis, McGill University, 2007.

Jacobsen, Douglas Gordon. Thinking in the Spirit: Theologies of the Early Pentecostal Movement. Bloomington: Indiana University Press, 2003.

Jones, Charles Edwin. A Guide to the Study of the Pentecostal Movement. 2 Vols. Metuchen, NJ: Scarecrow Press, 1983.

Jones, Charles Edwin. Black Holiness: A Guide to the Study of Black Participants in Wesleyan Perfectionist and Glossolaic Pentecostal Movements. Metuchen, NJ: Scarecrow Press, 1987. 
Jones, Charles Edwin. Perfectionist Persuasion: The Holiness Movement and American Methodism, 1867-1936. Metuchen, N.J.: Scarecrow Press, 1974.

Juster, Susan. Doomsayers: Anglo-American Prophecy in the Age of Revolution. Philadelphia: University of Pennsylvania Press, 2003.

Kaestle, Carl F., and Janice A. Radway, Print in Motion: The Expansion of Publishing and Reading in the United States, 1880-1940. Chapel Hill: University of North Carolina Press, 2008.

Kalu, Ogbu. African Pentecostalism: An Introduction. New York: Oxford University Press, 2008.

Kalu, Ogbu. Power, Poverty, and Prayer: the Challenges of Poverty and Pluralism in African Christianity, 1960-1996. Trenton, NJ: Africa World Press, 2006.

Kane, Holly Chairman. Arriving in Los Angeles: Railway Depots as Gateways to the Californian Dream. MA Thesis, University of Southern California, 2007. Accessed October 23rd, 2015. http://digitallibrary.usc.edu/cdm/ref/collection/p15799coll127/id/549791.

Kaufer, David S. and Kathleen M. Carley, Communication at a Distance: The Influence of Print on Sociocultural Organization and Change. Hillsdale, NJ: Erlbaum, 1993.

Keegan, Timothy J. Colonial South Africa and the Origins of the Racial Order. Charlottesville: University Press of Virginia, 1997.

Keith, LeeAnna. The Colfax Massacre: The Untold Story of Black Power, White Terror, and the Death of Reconstruction. Oxford: Oxford University Press, 2008.

Kendrick, Klaude. The Promised Fulfilled: A History of the Modern Pentecostal Movement. Springfield: Gospel Publishing House, 1961.

Killingray D. "The Black Atlantic Missionary Movement and Africa, 1780s 1920s" Journal of Religion in Africa, 1 January 2003, vol. 33, no. 1, pp. 331 (29).

King, Gerald W. Disfellowshipped: Pentecostal Responses to Fundamentalism in the United States, 1906-1943. Eugene, OR: Pickwick Publications, 2009. 
King, Gerald W. Disfellowshipped: Pentecostal Responses to Fundamentalism in the United States, 1906 - 1943, Eugene, OR: Pickwick Publications, [Princeton Theological Monograph Series], 2011.

King, Sandra L. The 1857 Hamilton Ontario Revival: An Exploration of the Origins of the Layman's Revival and the Second Great Awakening. Eugene, OR: Pickwick Publications. 2015.

Klug, Heinz. The Constitution of South Africa: A Contextual Analysis. Oxford: Hart Publishing, 2010.

Koss, Stephen E. The Pro-Boers: The Anatomy of an Antiwar Movement. Chicago: University of Chicago Press, 1973.

Krige, Eileen Jensen. The Social System of the Zulus, 1936. As quoted in Sundkler, Bengt. Bantu Prophets in South Africa. London: Published for the International African Institute by the Oxford University Press, 1961.

Kydd, Ronald. Finding Pieces of the Puzzle: A Fresh Look at the Christian Story. Eugene, Oregon: Wipf \& Stock Publishers, 2011.

LaBarre, Weston. They Shall Take Up Serpents: Psychology of the Southern Snake-Handling Cult. New York: Schocken Books, 1962.

Lake, John G., and Roberts Liardon. John G. Lake: The Complete Collections of His Life Teachings. New Kensington, PA: Whitaker House, 1999.

Landau, Paul Stuart. Popular Politics in the History of South Africa, 1400-1948. Cambridge: Cambridge University Press, 2010.

Landau, Paul Stuart. The Realm of the Word: Language, Gender, and Christianity in a Southern African Kingdom. Portsmouth, $\mathrm{NH}$ : Heinemann Social History of African Series, 1995

Landau, Paul. "'Religion' and Christian Conversion in African History: A New Model." The Journal of Religious History 23, no. 1 (1999): 8.

Larson, Edward J. Summer for the Gods: the Scopes Trial and America's Continuing Debate Over Science and Religion. Cambridge, MA: Harvard University Press, 1998.

Latham, Sean, and Robert Scholes. "The Rise of Periodical Studies". PMLA. 121 (2006): 517-531. 
Lawless, Elaine J. God's Peculiar People: Women's Voices \& Folk Tradition in a Pentecostal Church. Lexington, KY: University Press of Kentucky, 1988.

Lears, T. J. Jackson. Rebirth of a Nation: The Making of Modern America, 18771920. New York: HarperCollins, 2009.

Lever, Henry. "Ethnicity in South African Society". Humboldt Journal of Social Relations Department of Sociology, Humboldt State University 10, no. 1 (1982): 239-53. http://www.jstor.org/stable/23261866.

Levterov, Theodore N. The Development of the Seventh-Day Adventist Understanding of Ellen G. White's Prophetic Gift: 1844-1889. American University Studies - Series VII: Theology and Religion, Vol. 347. New York: Peter Lang, 2015.

Levy, Norman. The Foundations of the South African Cheap Labour System. London: Routledge \& Kegan Paul, 1982.

Limerick, Patricia Nelson. The Legacy of Conquest: The Unbroken Past of the American West. New York: W. W. Norton \& Company, 1987.

Lindhardt, Martin. Pentecostalism in Africa: Presence and Impact of Pneumatic Christianity in Postcolonial Societies. Boston: Brill, 2014.

Lindsay, Gordon. They Saw it Happen! Dallas, TX: Christ for the Nations, 1972.

Logan, Rayford Whittingham. The Negro and the Post-War World, A Primer. Washington, D.C.: Minorities Publishers, 1945.

Logan, Rayford Whittingham. The Negro in American Life and Thought: The Nadir, 1877-1901. New York: Dial Press, 1954.

Long, Kathryn Teresa. The Revival of 1857-58: Interpreting an American Religious Awakening. New York: Oxford University Press, 1998.

Loubser, J. A. A Critical Review of Racial Theology in South Africa: the Apartheid Bible. Texts and Studies in Religion, v. 53. Lewiston, NY: E. Mellen Press, 1990.

Luker, Ralph. The Social Gospel in Black and White: American Racial Reform, 1885-1912. Chapel Hill: The University of North Carolina Press, 1991.

Lynerd, Benjamin T. "The Purpose-Driven Darwinist: Henry Ward Beecher and the Theology of Progress". Political Theology 17, no. 1 (2016): 47-72. 
Mabika, Hines. "History of Community Health in Africa. The Swiss Medical Missionaries' Endeavour in South Africa". Gesnerus. 72, no. 1 (2015): 135-158.

MacRobert, lain. The Black Roots and White Racism of Early Pentecostalism in the USA. New York: St. Martin's Press, 1988.

Magaziner, Daniel R. The Law and the Prophets: Black Consciousness in South Africa, 1968-1977. Athens: Ohio University Press, 2010.

Mahoney, Joseph. "Woman Suffrage and the Urban Masses." New Jersey History 87, no. 3 (1969): 151-172.

Majeke, Nosipho. The Role of the Missionaries in Conquest. Johannesburg: Society of Young Africa, 1952.

Mamdani, Mahmood. Citizen and Subject: Contemporary Africa and the Legacy of Late Colonialism. Princeton, N.J.: Princeton University Press, 1996.

Mandela, Nelson. Long Walk to Freedom: The Autobiography of Nelson Mandela. New York: Little, Brown, and Company, 1994.

Marks, Shula. The Ambiguities of Dependence in South Africa: Class, Nationalism, and the State in Twentieth-Century Natal. Baltimore: Johns Hopkins University Press, 1986.

Marsden, George M. Fundamentalism and American Culture: The Shaping of Twentieth Century Evangelicalism, 1870-1925. New York: Oxford University Press, 1980.

Marsden, George M. Understanding Fundamentalism and Evangelicalism. Grand Rapids, MI: William B. Eerdmans Publishing Co., 1991.

Martin, Larry E., Ed., The Doctrines and Discipline of the Azusa Street Apostolic Faith Mission of Los Angeles, California. Joplin, MO: Christian Life Books, 2000.

Martin, Larry E. The Life and Ministry of William J. Seymour: And a History of the Azusa Street Revival. Joplin, MO: Christian Life Books, 1999.

Martin, Larry E. Saved and Sanctified, Joplin, MO: Christian Life Books, 2005. 
Martin, Robert Francis. Hero of the Heartland: Billy Sunday and the Transformation of American Society, 1862-1935. Bloomington: Indiana University Press, 2002.

Marx, Anthony W. Making Race and Nation: A Comparison of South Africa, the United States, and Brazil. Cambridge, U.K: Cambridge University Press, 1998.

Mathews, Donald G. Religion in the Old South. Chicago: University of Chicago Press, 1977.

Maxwell, David. African Gifts of the Spirit: Pentecostalism \& the Rise of a Zimbabwean Transnational Religious Movement. Oxford: James Currey, 2006.

Maxwell, David “'Delivered From the Spirit of Poverty?': Pentecostalism, Prosperity and Modernity in Zimbabwe" Journal of Religion in Africa 28, no. 3 (1998): 350-373(24)

Maxwell, David "Editorial" Journal of Religion in Africa 29, no. 2 (1999): 135-139.

Maxwell, David "Editorial" Journal of Religion in Africa 29, no. 3 (1999): 239-241.

Maxwell, David. "Networks and Niches: The Worldwide Transmission of the Azusa Street Revival" in The Azusa Street Revival and Its Legacy by Harold D. Hunter and Cecil M. Robeck Jr., Eds., Eugene, OR: Wipf and Stock Publishers, 2006.

Maxwell, David "The Durawall of Faith: Pentecostal Spirituality in Neo-Liberal Zimbabwe" Journal of Religion in Africa 35, no. 1 (2005): 4-32.

McArthur, Benjamin. "Millennial Fevers". Reviews in American History 24, no. 3 (1996): 369-382.

McBride, Genevieve. On Wisconsin Women: Working for Their Rights from Settlement to Suffrage. Madison: The University of Wisconsin Press, 1993.

McCarthy, Kathleen D. Lady Bountiful Revisited: Women, Philanthropy and Power. New Brunswick: Rutgers University Press, 1990.

McGerr, Michael E. A Fierce Discontent: The Rise and Fall of the Progressive Movement in America, 1870-1920. New York: Free Press, 2003. 
McLoughlin, William G. Modern Revivalism: Charles Grandison Finney to Billy Graham, Ronald Press Company, 1959. Reprint, Eugene, OR: Wipf \& Stock Publishers, 2004.

McPherson, James M. Ordeal by Fire: The Civil War and Reconstruction. New York: McGraw-Hill, 1992.

Meinig, D. W. The Shaping of America: A Geographical Perspective on 500 Years of History: Volume 3: Transcontinental America 1850-1915. New Haven: Yale University Press, 1998.

Menzies, William W., Anointed to Serve: The Story of the Assemblies of God, Springfield, MO: Gospel Publishing House, 1971.

Miller, Donald E., Kimon Howland Sargeant, and Richard W. Flory. Spirit and Power: The Growth and Global Impact of Pentecostalism. New York: Oxford University Press, 2013.

Mills, E. Charismatic Religion in Modern Research: A Bibliography. Macon, GA: Mercer University Press, 1985.

Moodie, T. Dunbar. The Rise of Afrikanerdom: Power, Apartheid, and the Afrikaner Civil Religion. Berkeley: University of California Press, 1975.

Moody Bible Institute. "The Bible Institute Colportage Association," The Christian Workers Magazine, Chicago: Moody Bible Institute of Chicago 17, No. 6. (February 1917).

Moore, Basil. The Challenge of Black Theology in South Africa. Atlanta: John Knox Press, 1974.

Moorehead, James $\mathrm{H}$. "The Millennium and the Media" in Communication and Change in American Religious History. Leonard I. Sweet, Ed., Grand Rapids, MI: William B. Eerdmans Publishing Co., 1993.

Moorhead, James H. World Without End: Mainstream American Protestant Visions of the Last Things, 1880-1925. Bloomington: Indiana University Press, 1999.

Müller, Retief. 2011. African Pilgrimage: Ritual Travel in South Africa's Christianity of Zion. Farnham, Surrey, England: Ashgate, 2011.

Mungazi, Dickson A. In the Footsteps of the Masters: Desmond M. Tutu and Abel T. Muzorewa. Westport, CT: Praeger, 2000. 
Mungazi, Dickson A. In the Footsteps of the Masters: Desmond M. Tutu and Abel T. Muzorewa. Westport, CT: Praeger, 2000.

Nasson, Bill. Abraham Esau's War: A Black South African War in the Cape, 1899-1902. Cambridge, England: Cambridge University Press, 1991.

Nasson, Bill. The War for South Africa. Cape Town: Tafelberg, 2010.

Nelson, Douglas J. "For Such a Time as This: The Story of Bishop William J. Seymour and the Azusa Street Revival: A Search for Pentecostal/Charismatic Roots." Ph.D. Dissertation, University of Birmingham, 1981.

Newell, Sasha "Pentecostal Witchcraft: Neoliberal Possession and Demonic Discourse in Ivoirian Pentecostal Churches" Journal of Religion in Africa, December 2007, vol. 37, no. 4, pp. 461-490 (30).

Newman, Joe. Race and the Assemblies of God Church: the Journey from Azusa Street to the "Miracle of Memphis". Youngstown, N.Y.: Cambria Press, 2007.

Nichols, John Thomas. Pentecostalism. New York: Harper \& Row, 1966.

Nienkirchen, Charles W. A. B. Simpson and the Pentecostal Movement. Peabody, MA: Hendrickson, 1992.

Nolan, Albert. God in South Africa: the Challenge of the Gospel. Cape Town: D. Philip, 1988.

Noll, Mark A. America's God: From Jonathan Edwards to Abraham Lincoln. Oxford: Oxford University Press, 2002.

Noll, Mark A. The Civil War as a Theological Crisis. Chapel Hill: The University of North Carolina Press, 2006.

Nord, David Paul. Faith in Reading: Religious Publishing and the Birth of Mass Media in America. New York: Oxford University Press, 2004.

O'Connor, Edward. The Pentecostal Movement in the Catholic Church. Norte Dame, IN: Ave Maria Press, 1971.

O'Brien, Elmer J. The Wilderness, the Nation, and the Electronic Era: American Christianity and Religious Communication, 1620-2000 : an annotated bibliography. Lanham, MD: Scarecrow Press, 2009. 
Omissi, David E., and Andrew S. Thompson. The Impact of the South African War. Houndmills, Basingstoke, Hampshire: Palgrave, 2002.

Oosthuizen, G. C. Pentecostal Penetration into the Indian Community in South Africa. Durban: Human Sciences Research Council, 1975.

Oosthuizen, Gerhardus C., and Irving Hexham. Afro-Christian Religion at the Grassroots in Southern Africa. Lewiston, NY: E. Mellen, 1991.

Oosthuizen, Gerhardus. C. The Healer-Prophet in Afro-Christian Churches. Leiden, The Netherlands: E.J. Brill, 1992.

Orr, J. Edwin, and Richard Owen Roberts. The Event of the Century: The 18571858 Awakening. Wheaton, IL: International Awakening Press, 1989.

Owens, Robert R. Speak to the Rock: The Azusa Street Revival, its Roots and its Message. Lanham, MD: University Press of America, 1998.

Owens, Robert R. The Azusa Street Revival: Its Roots and lts Message. Lanham, MD: Xulon Press, 2005.

Painter, Nell Irvin. Exodusters: Black Migration to Kansas After Reconstruction. New York: Knopf, 1977,

Painter, Nell Irvin. Standing at Armageddon: the United States, 1877-1919. New York: W.W. Norton, 1987.

Paris, Arthur E. Black Pentecostalism: Southern Religion in an Urban World. Amherst, MA: The University of Massachusetts Press, 1982.

Park, Benjamin E. "Early Mormon Patriarchy and the Paradoxes of Democratic Religiosity in Jacksonian America," American Nineteenth Century History 14, no. 2, (2013): 183-208.

Park, Yoon "Living In Between: The Chinese in South Africa" The Online Journal of the Migration Policy Institute. January 4th, 2012, accessed January 9 , 2016. http://www. migrationpolicy.org/article/living-between-chinese-southafrica.

Patterson, Eric, and Edmund J. Rybarczyk. The Future of Pentecostalism in the United States. Lanham, MD: Lexington Books, 2007. 
Paulin, Christopher M. White Men's Dreams, Black Men's Blood: African Labor and British Expansionism in Southern Africa, 1877-1895. Trenton, NJ: Africa World Press, 2001.

Peel, Robert. Mary Baker Eddy: The Years of Authority. New York: Holt, Rinehart and Winston, 1977.

Peires, Jeffrey Brian. The Dead will Arise: Nongqawuse and the Great Xhosa Cattle-Killing Movement of 1856-7. Johannesburg: Ravan Press, 1989. Reprint, 2000.

Penton, M. James. Apocalypse Delayed: The Story of Jehovah's Witnesses. Toronto: University of Toronto Press, 2015.

Peterson, Bhekizizwe. Monarchs, Missionaries \& African Intellectuals: African Theater and the Unmaking of Colonial Marginality. Trenton, NJ: Africa World Press, 2000.

Pettitt, Clare. Dr. Livingstone, I Presume?: Missionaries, Journalists, Explorers, and Empire. Cambridge, MA: Harvard University Press, 2007.

Pew Forum on Religion \& Public Life, and Pew Research Center. 2011. Global Christianity: a report on the size and distribution of the world's Christian population. Washington, D.C.: Pew Research Center. Accessed January $4^{\text {th }}$, 2016. http://www.pewforum.org/Christian/Global-Christianityexec.aspx.

Pillay, Gerald J. "Community Service and Conversion: Christianity among Indian South Africans" in Elphick, Richard, and T. R. H. Davenport. Christianity in South Africa: A Political, Social, and Cultural History. Berkeley, Calif: University of California Press, 1997.

Pillay, Gerald J. "The Use of Functional-Type Theories in the Study of Independent Christian Movements: A Critique". Neue Zeitschrift Für Missionswissenschaft 44, no. 2 (1988). As cited in Allan Anderson, Bazalwane: African Pentecostals in South Africa. Pretoria: University of South Africa, 1992.

Pluess, Jean-Daniel. "One in the Spirit? Pentecostals and the Yearning for Christian Unity: A Case Study of the Swiss Pentecostal Mission and Its Initiatives Towards Unity in the Spirit" in John Gibaut and Knud Jorgensen, Called to Unity: For the Sake of Mission. Eugene, OR: Wipf and Stock Publishers, 2014. 
Porter, Bernard. The Lion's Share: A History of British Imperialism, 1850-2011. Harlow, England: Pearson, 2012.

Porterfield, Amanda. The Transformation of American Religion: the Story of a Late-Twentieth-Century Awakening. Oxford: Oxford University Press, 2001.

Prinsloo, D. "Die-Johannesburg-periode in Dr. H.F. Verwoerd se loopbaan," Doctoral Dissertation: RAU, 1979.

Prinsloo, Mastin. "Literacy in South Africa" pg. 5, accessed February 14 2016. http://www.education.uct.ac.za/sites/default/files/image_tool/images/104/9 9 literacyinsouthafrica.pdf. The final version of this article is in Wagner, Daniel A., Richard L. Venezky, and Brian V. Street. Literacy: An International Handbook. Boulder, CO: Westview Press, 1999.

Pype, Katrien "Dancing for God or the Devil: Pentecostal Discourse on Popular Dance in Kinshasa" Journal of Religion in Africa 36, no. 3-4 (November 2006): 296-318.

Quandt, Jean B. "Religion and Social Thought: The Secularization of Postmillennialism". American Quarterly. 25, no. 4 (1973): 390-409.

Quintana-Murci, Lluis, C Harmant, H Quach, O Balanovsky, V Zaporozhchenko, C Bormans, van Helden PD, EG Hoal, and DM Behar. "Strong Maternal Khoisan Contribution to the South African Coloured Population: a Case of Gender-Biased Admixture". American Journal of Human Genetics. 86, no. 4 (2010): 611-620.

Raboteau, Albert J. Slave Religion: The "Invisible Institution" in the Antebellum South. New York: Oxford University Press, 1978.

Ransom, Roger L., and Richard Sutch, One Kind of Freedom: The Economic Consequences of Emancipation. Cambridge, England: Cambridge University Press, 1977.

Redding, Sean. Sorcery and Sovereignty: Taxation, Power, and Rebellion in South Africa, 1880-1963. Athens, OH: Ohio University Press, 2006.

Redding, Sean. Sorcery and Sovereignty: taxation, power, and rebellion in South Africa, 1880-1963. Athens, OH: Ohio University Press, 2006. 
Riesebrodt, Martin. Pious Passion: The Emergence of Modern Fundamentalism in the United States and Iran, Los Angeles, CA: University of California Press, 1993.

Rios-Bustamante, Antonio. "The Once and Future Majority," California History 60 (Spring 1981): 24-25.

Risjord, Norman K. Representative Americans: Populists and Progressives. Lanham: Rowman \& Littlefield, 2005.

Robins, R. G. A.J. Tomlinson: Plainfolk Modernist. Oxford: Oxford University Press, 2004.

Robins, R. G. Pentecostalism in America. Santa Barbara, CA: Praeger, 2010.

Robinson, James. Divine Healing, The Formative Years, 1830-1890: Theological Roots in a Transatlantic World. Eugene, OR: Pickwick Publishers of Wipf \& Stock Publishers, 2011.

Robinson, James. Divine Healing: The Years of Expansion, 1906-1930:

Theological Variation in the Transatlantic World. Eugene, OR: Pickwick Publications, 2014.

Robeck, Cecil M. Charismatic Experiences in History. Peabody, Mass: Hendrickson Publishers, 1985.

Robeck, Cecil M. "The Azusa Street Mission and Historic Black Churches: Two Worlds in Conflict in Los Angeles' African American Community" in Amos Young and Estrelda Alexander, Eds. Afro-Pentecostalism: Black Pentecostal and Charismatic Christianity in History and Culture. New York, NY: New York University Press, 2011.

Robeck, Cecil M. The Azusa Street Mission and Revival: The Birth of the Global Pentecostal Movement. Nashville: Nelson Reference \& Electronic, 2006.

Robeck, Cecil M., and Amos Yong. The Cambridge Companion to Pentecostalism. New York: Cambridge University Press, 2014.

Ross, Andrew. John Philip (1775-1851): Missions, Race and Politics in South Africa. Aberdeen, UK: Aberdeen University Press, 1986.

Ross, Robert, Anne Kelk Mager, and Bill Nasson, Eds. The Cambridge History of South Africa. 1st ed. Vol. 2. Cambridge: Cambridge University Press, 
2011. Cambridge Histories Online. Web. February $8^{\text {th }}, 2016$. http://dx.doi.org/10.1017/CHOL9780521869836

Rowe, David L. "Millerites, A Shadow Portrait," in Ronald L. Numbers and Jonathan M. Butler, eds., The Disappointed: Millerism and Millenarianism in the Nineteenth Century. Bloomington: Indiana University Press, 1987.

Rubin, Margot W. The Jewish Community of Johannesburg, 1886-1939: Landscapes of Reality and Imagination. M.A. Thesis: University of Pretoria, 2004.

Sales, Jane M. The Planting of the Churches in South Africa. Grand Rapids, MI: Eerdmans, 1971.

Sandeen, Ernest Robert. The Roots of Fundamentalism: British and American Millenarianism, 1800-1930. Chicago: University of Chicago Press, 1970.

Sanders, Cheryl Jeanne. Saints in Exile: the Holiness-Pentecostal Experience in African American Religion and Culture. New York: Oxford University Press, 1999.

Sanders, Rufus G. W. William Joseph Seymour: Black Father of the Twentieth Century Pentecostal/charismatic Movement. Sandusky, Ohio: Alexandria Publications, 2001.

Sanneh, Lamin O. Translating the Message: The Missionary Impact on Culture. Maryknoll, N.Y.: Orbis Books, 1989.

Saunders, Christopher C. The Making of the South African Past: Major Historians on Race and Class. Totowa, N.J.: Barnes \& Noble Books, 1988.

Saron, G., and L. Hotz, The Jews in South Africa: A History. Cape Town: Oxford University Press, 1955.

Scholes, Robert, and Clifford Wulfman. Modernism in the Magazines: An Introduction. New Haven: Yale University Press, 2010.

Scott, Anne Firor, and Andrew McKay Scott, One Half the People: The Fight for Woman Suffrage. Urbana: University of Illinois Press, 1982.

Sernett, Milton C. Black Religion and American Evangelicalism: White Protestants, Plantation Missions, and the Flowering of Negro Christianity, 1787-1865. Metuchen, N.J.: Scarecrow Press, 1975. 
Shackel, Paul A., and Matthew M. Palus, "The Gilded Age and Working-Class Industrial Communities." American Anthropologist, 108, No. 4 (December 2006): 828-841.

Shaw, Margaret. "Material Culture," in W.D. Hammond-Tooke, ed., The BantuSpeaking Peoples of Southern Africa, London, Routledge \& Kegan Paul, 1974.

Shell, Robert Carl-Heinz. Children of Bondage: A Social History of the Slave Society at the Cape of Good Hope, 1652 - 1838. Hanover: University Press of New England, 1994.

Sisulu, Elinor. Walter \& Albertina Sisulu: In Our Lifetime. Claremont, South Africa: David Philip, 2003.

Smith, David M. The Apartheid City and Beyond: Urbanization and Social Change in South Africa. London: Routledge, 1992.

Smith, Edwin W. "The Idea of God Among South African Tribes," in Edwin W. Smith (Ed.) African Ideas of God. London: Edinburgh House Press, 1950.

Smith, John W. V. A Brief History of the Church of God Reformation Movement, Anderson, IN: Warner Press, 1976.

Smith, Timothy Lawrence, and W. T. Purkiser. Called Unto Holiness; The Story of the Nazarenes. Kansas City, Mo: Nazarene Pub. House, 1962.

Society for Pentecostal Studies, "Who We Are." Accessed Jan 4, 2016. http://www.sps-usa.org/\#/home/who-we-are.

South African History Online, "The Great Trek," accessed Dec 10, 2010. http://www.sahistory.org.za/pages/governence-projects/great-trek/greattrek1.htm.

South African History Online: Toward a People's History, "Race and Ethnicity in South Africa." March 23rd, 2015, accessed January 25th, 2016. http://www.sahistory.org.za/article/race-and-ethnicity-south-africa.

Stanley, Burgess, Gary McGee, Patrick Alexander. Dictionary of Pentecostal and Charismatic Movements. Grand Rapids, MI: Regency Reference Library, 1988.

Starr, Paul. The Creation of the Media: Political Origins of Modern Communication. New York: Basic Books, 2005. 
Stephens, Randall J. The Fire Spreads: Holiness and Pentecostalism in the American South. Cambridge, MA: Harvard University Press, 2008.

Stowell, Daniel W. Rebuilding Zion: The Religious Reconstruction of the South. New York: Oxford University Press, 1998.

Sundkler, Bengt, and Christopher Steed. A History of the Church in Africa. Studia missionalia Upsaliensia, 74. Cambridge, UK: Cambridge University Press, 2000.

Sundkler, Bengt. Bantu Prophets in South Africa. London: Oxford University Press, 1961.

Sundkler, Bengt. Zulu Zion and Some Swazi Zionists. London: Oxford University Press, 1976.

Sutton, Matthew Avery. Aimee Semple McPherson and the Resurrection of Christian America. Cambridge, MA: Harvard University Press, 2007.

Sutton, Matthew Avery. American Apocalypse: A History of Modern Evangelicalism. Cambridge, Massachusetts: Belknap Press of Harvard University Press, 2014.

Swart, C.F. "Urbanization - Catalyst for Socio-Economic and Political Change" in D.J. Van Vuuren, et al, Change in South Africa. Durban: Butterworths, 1983.

Synan, Vinson ed. Aspects of Pentecostal/Charismatic Origins. Plainfield, NJ: Logos International, 1975.

Synan, Vinson. The Holiness-Pentecostal Tradition: Charismatic Movements in the Twentieth Century. Grand Rapids, Ml: Eerdmans, 1971.

Synan, Vinson. The Twentieth-Century Pentecostal Explosion: the Exciting Growth of Pentecostal Churches and Charismatic Renewal Movements. Altamonte Springs, FL, Creation House, 1987.

Szasz, Ferenc Morton. Religion in the Modern American West. Tucson, AZ: University of Arizona Press, 2000.

Taylor, Quintard. In Search of the Racial Frontier: African Americans in the American West, 1528-1990. New York: Norton, 1998. 
Tejani, James. "Dredging the Future: The Destruction of Coastal Estuaries and the Creation of Metropolitan Los Angeles, 1858-1913," Southern California Quarterly, Vol. 96, No. 1 (Spring 2014): 5-39.

Thomas, David Gervaise. Christ Divided: Liberalism, Ecumenism and Race in South Africa. Pretoria: University of South Africa, 2002.

Thomas, Joseph L. Perfect Harmony: Interracial Churches in Early HolinessPentecostalism, 1880-1909. Lexington: Emeth Press, 2014.

Thompson, Leonard Monteath. A History of South Africa. New Haven: Yale University Press, 1990.

Thompson, Leonard Monteath. The Political Mythology of Apartheid. New Haven: Yale University Press, 1985.

Trachtenberg, Alan, and Eric Foner. The Incorporation of America: Culture and Society in the Gilded Age. New York: Hill and Wang, 1982.

Trelease, Allen W. White Terror; The Ku Klux Klan Conspiracy and Southern Reconstruction. New York: Harper \& Row, 1971.

Turner, William Clair. The United Holy Church of America: a study in Black Holiness-Pentecostalism. Piscataway, NJ: Gorgias Press, 2006.

Tuveson, Ernest. Redeemer Nation: The Idea of America's Millennial Role [1968]; rpt., Chicago: University of Chicago Press, 1980.

Tyson, James L. The Early Pentecostal Revival: History of Twentieth-Century Pentecostals and the Pentecostal Assemblies of the World, 1901-30. Hazelwood, MO: Word Aflame Press, 1992.

U.S Geological Survey. "Historic Earthquakes: San Francisco, California. 1906 0418 13:12:21 UTC, Magnitude 7.8" US Geological Survey, (October, 2009), Page Last Modified: April 06, 2016 20:18:59 UTC. Accessed June 16, 2016. http://earthquake.usgs.gov/earthquakes/states/events/1906_04_18.php

Vail, Leroy. The Creation of Tribalism in Southern Africa. Berkeley: University of California Press, 1991.

van Heyningen, Elizabeth. "Costly Mythologies: The Concentration Camps of the South African War in Afrikaner Historiography". Journal of South African Studies 34, no. 3 (2008): 495-513. 
van Warmelo, N.J. "The Classification of Cultural Groups," in W.D. HammondTooke, ed., The Bantu-Speaking Peoples of Southern Africa, London, Routledge \& Kegan Paul, 1974.

Venter, Dawid. Engaging Modernity: Methods and Cases for Studying African Independent Churches in South Africa. Westport, CT: Praeger Publishers, 2004.

Villa-Vicencio, Charles. Trapped in Apartheid: A Socio-Theological History of the English-Speaking Churches. Marynoll, NY: Orbis Books, 1988.

Vinson, Robert T. The Americans Are Coming!: Dreams of African American Liberation in Segregationist South Africa. Athens, Ohio: Ohio University Press, 2011.

Vondey, Wolfgang. "Pentecostalism and Ecumenism" in Robeck Jr., Cecil M., and Amos Yong. The Cambridge Companion to Pentecostalism. Cambridge: Cambridge University Press, 2014.

Wacker, Grant. "Are the Golden Oldies Still Worth Playing? Reflections on History Writing among Early Pentecostals." Pneuma 8 (1986) 81-100.

Wacker, Grant. "Early Pentecostals and the Almost Chosen People." 1997 Presidential Address. Pneuma 19 (1997) 141-166.

Wacker, Grant. Heaven Below: Early Pentecostals and American Culture. Cambridge, MA: Harvard University Press, 2001.

Wacker, Grant. "Marching to Zion: Religion in a Modern Utopian Community". Church History 54, no. 4 (1985): 496-511.

Wacker, Grant, Religion in Nineteenth Century America, Religion in American Life Series, New York: Oxford University Press, 2000.

Waldvogel, Edith Lydia. The "Overcoming Life": A Study in the Reformed Evangelical Origins of Pentecostalism: a Thesis. Cambridge, Mass: Waldvogel, 1977.

Walshe, Peter. Church Versus State in South Africa: the Case of the Christian Institute. London: C. Hurst \& Co, 1983.

Walshe, Peter. Prophetic Christianity and the Liberation Movement in South Africa. Pietermaritzburg: Cluster Publications, 1995. 
Warner, Wayne E. The Woman Evangelist: The Life and Times of Charismatic Evangelist Maria B. Woodworth-Etter. Metuchen, NJ: Scarecrow Press, 1986.

Warner, Wayne E. Touched by the Fire: Patriarchs of Pentecost. Plainfield, NJ: Logos International, 1978. (reissued as Revival! Touched by Pentecostal Fire, 1982).

Warner, Wayne E. Touched by the Fire: Eyewitness Accounts of the Early Twentieth-Century Pentecostal Revival. Plainfield, NJ: Logos International, 1978.

Warwick, Peter. The South African War: The Anglo-Boer War, 1899-1902. London: Longman, 1980.

Waters, Ken. "Vibrant, But Invisible: A Study of Contemporary Religious Periodicals" J\&MC Quarterly. Vol 78, No. 2 (2001): 307-320.

Weber, Timothy P. Living in the Shadow of the Second Coming: American Premillennialism, 1875-1925. New York: Oxford University Press, 1979.

Wenzel, Jennifer. Bulletproof: Afterlives of Anticolonial Prophecy in South Africa and Beyond. Chicago: The University of Chicago Press, 2009.

West, Elliott. "Reconstructing Race". The Western Historical Quarterly 34, no. 1 (2003): 6-26.

West, Martin. Bishops and Prophets in a Black City: African Independent Churches in Soweto, South Africa. Cape Town: D. Phillip, 1975.

Wheeler, Marjorie Spruill. New Women of the South: The Leaders of the Woman Suffrage Movement in the Southern States. New York: Oxford University Press, 1993.

White, Calvin. Jr. The Rise to Respectability: Race, Religion, and the Church of God in Christ. Fayetteville, AR: The University of Arkansas Press, 2012.

White, Richard. It's Your Misfortune and None of My Own: A New History of the American West. Norman: University of Oklahoma, 1993.

Wild, Mark. Street Meeting: Multiethnic Neighborhoods in Early Twentiethcentury Los Angeles. Berkley and Los Angeles, CA: University of California Press, 2005. 
Williams, Walter L. Black Americans and the Evangelization of Africa, 1877-1900. Madison, WI: University of Wisconsin Press, 1982.

Williamson, Joel. The Crucible of Race: Black-White Relations in the American South Since Emancipation. New York: Oxford University Press, 1984.

Wilson, Everett A. "They Crossed the Red Sea, Didn't They? Critical History and Pentecostal Beginnings" in Murray W. Dempster, Byron D. Klaus \& Douglas Petersen, Eds., The Globalization of Pentecostalism: A Religion Made to Travel. Oxford: Regnum, 1999.

Wilson, Francis. Labour in the South African Gold Mines 1911-1969. Cambridge, England: University Press, 1972.

Wood, Gordon. "Evangelical America and Early Mormonism," New York History 61, (1980): 359-386.

Worden, Nigel. Slavery in Dutch South Africa. Cambridge: Cambridge University Press, 1985.

Yong, Amos, and Estrelda Alexander. Afro-Pentecostalism: Black Pentecostal and Charismatic Christianity in History and Culture. New York: New York University Press, 2011.

Zaret, David. Origins of Democratic Culture: Printing, Petitions, and the Public Sphere in Early-Modern England. Princeton, N.J.: Princeton University Press, 2000.

Ziefle, Joshua R. David Du Plessis and the Assemblies of God: The Struggle for the Soul of a Movement. Leiden: Brill, 2013.

Zondi, Siphamandla. African Demand and Missionary Response: The Emergence of Missionaries As Healers in KwaZulu Natal, 1835-1930. Cambridge: Currents in World Christianity Incorporating North Atlantic Missiology Project, 1998.

\section{Primary Sources}

Barratt, Thomas Ball. In the Days of the Latter Rain. Oslo, Norway, 1909. Reprinted by the Garland Publishing Company in the Higher Life Series, New York, 1985. 
Bartleman, Frank. How Pentecost Came to Los Angeles. Los Angeles, 1925.

Bartleman, Frank. My Story "the Latter Rain". Columbia, SC: John M. Pike, 1909. Accessed January $16^{\text {th }}, 2016$. http://www.ccel.org/ccel/bartleman/story/Page_1.html

Bedwell, H. Kenneth. Black Gold: the Story of the International Holiness Mission in South Africa, 1908-1936. (Cape Town [South Africa]: Cape Times Ltd.), 193 ?.

Beecher, Henry Ward. "Preaching Christ" in Sermons by Henry Ward Beecher, Vol. 2. Plymouth Church, Brooklyn, NY. New York: Harper and Brothers Publishers, 1868.

Bell, E. N. Questions and Answers. St. Louis, Mo: Gospel Publishing House, 1923.

Blackstone, W.E. Jesus is Coming. New York, NY: Fleming H. Revell Co., 1898.

Boardman, William Edwin. The Higher Christian Life, Chicago, IL: W.M. Tomlinson, 1858. Archive.org, accessed December $18^{\text {th }} 2015$. http://www.archive.org/stream/higherchristianlife00boarrich\#page/n5/mode /2up.

Boyd, Frank M. The Budding Fig Tree. St. Louis, Mo: Gospel Publishing House, 1925.

Brookes, Edgar Harry, et al., Coming of Age: Studies in South African Citizenship and Politics. Cape Town: Maskew Millar, 1930.

Britton, F.M. Pentecostal Truth, or Sermons on Regeneration, Sanctification, the Baptism of the Holy Spirit, Divine Healing, the Second Coming of Jesus, etc. Royston, GA: Publishing House of the Pentecostal Holiness Church, 1919.

Eddy, Mary Baker. Science and Health, with Key to the Scriptures. One hundred and eighty-third edition. Boston, Mass: Joseph Armstrong C.S.D. 1900.

Flower, Alice Reynolds Love's Overflowing. St. Louis, Mo: Gospel Publishing House, 1928.

Maria Martha Fraser, Getuienis van Geestelike Groei, van Geloofslewe en van Werkinge van die Heilige Gees. Benoni: Spade Reen Gemeentes van 
Suid-Afrika, 1974. South Africa National Archives, Cape Town Archives Repository.

Frodsham, Stanley H. Things Which Must Shortly Come to Pass. St. Louis, Mo: Gospel Publishing House, 1928.

Frodsham, Stanley H. With Signs Following: The Story of the Latter-Day Pentecostal Revival. St. Louis, Mo: Gospel Publishing House, 1926. (Revised 1946)

Huff, Etta Auringer. "A Scriptural Pentecost," A Herald of Light, July 14, 1906, reprinted in Larry Martin, ed., Azusa Street: The True Believers Part 2. Joplin, MO: Christian Life Books, 1999.

Lake, John G., and Wilford H. Reidt. Adventures in God. Tulsa, OK: Harrison House, 1981 (This manuscript was compiled by John G. Lake's son-inlaw, Wilford H. Reidt).

Lawrence, Bennett Freeman. The Apostolic Faith Restored. St. Louis, Mo: Gospel Publishing House, 1916.

Los Angeles Examiner, Los Angeles, 1903-1961. Center for Research Libraries. http://www.crl.edu/

Los Angeles Herald, Los Angeles, 1873-1918. Newspapers.com. www.newspapers.com.

Los Angeles Times, Los Angeles, 1886-1930. Center for Research Libraries. http://www.crl.edu/

Los Angeles Evening News, Los Angeles, 1900-1911. Center for Research Libraries. http://www.crl.edu/

Los Angeles Star, Los Angeles, 1851-1864. California Digital Newspaper Collection. http://cdnc.ucr.edu/

Luce, Alice. The Messenger and His Message. St. Louis, Mo: Gospel Publishing House, 1925.

Allen, Frederick Lewis. Only Yesterday: An Informal History of the NineteenTwenties

(New York: Harper \& Brothers Publishers, 1931; reprint, John Wiley \& Sons, 1997). 
McPherson, Aimee Semple. In the Service of the King. (New York: Boni and Liveright), 1927.

McPherson, Aimee Semple. The Foursquare Gospel. (Los Angeles: Robertson Printing Company), 1946.

McPherson, Aimee Semple. The Story of My Life. (Los Angeles: Echo Park Evangelistic Association), 1951.

McPherson, Aimee Semple. This is That: Personal Experiences, Sermons, and Writings of Aimee Semple McPherson. (Los Angeles: Echo Park Evangelistic Association), 1923.

Parham, Charles. A Voice Crying in the Wilderness. Kansas City, MO: By the author, 1902; reprint ed., Joplin, Missouri: Joplin Printing Co., 1944.

Parham, Charles F. The Everlasting Gospel, 1st ed. Baxter Springs, KS: Apostolic Faith Bible College, 1911.

Parham, Sarah E. The Life of Charles F. Parham, Founder of the Apostolic Faith Movement. Joplin, MO: Tri-State Print. Co, 1930.

Parliamentary Papers, 1902, LXVIII Cd. 939. Online in Stanford University's Africana Collections "Concentration Camps, Parliamentary Papers, 1902, LXVIII", accessed Dec. 10 $10^{\text {th }}, 2010$. http://www.sul.stanford.edu/depts/ssrg/africa/parlstat.html

Pearlman, Myer. The Heavenly Gift. St. Louis, Mo: Gospel Publishing House, 1925.

Puck Magazine. New York, NY: Keppler \& Schwarzmann. Vol. 25, No. 624. (May 1st, 1889), accessed June $12^{\text {th }} 2015$. https://books.google.com/books?id=rvggAQAAMAAJ\&pg=PA12\#v=onepa ge\&q\&f=false.

Riggs, Ralph M. A Successful Pastor. St. Louis, Mo: Gospel Publishing House, 1931.

Riggs, Ralph M. A Successful Sunday School. St. Louis, Mo: Gospel Publishing House, 1934.

Seymour, William Joseph. The Great Azusa Street Revival: the Life and Sermons of William Seymour. (Fort Lauderdale, Fla: Wilmington Pub. Group.), Reprint, 2006. 
Shumway, Charles William. "A Critical Study of 'The Gift of Tongues," A.B. Dissertation, University of Southern California, 1914.

Sizelove, Rachel A. "A Sparkeling Fountain for the Whole Earth," Word and Work, June 1934.

Smith, Mr. and Mrs. P. D. Delivered from Bandits, Cannibals and Lions: And Other True Missionary Stories. St. Louis, Mo: Gospel Publishing House, 1932.

The Leavenworth Times. Leavenworth: Kansas, December 6th, 1906. Newspapers.com.

Topeka Daily Capital, January 6, 1901. Newspapers.com.

Vanzandt, J. C. Speaking in Tongues: A Discussion of Speaking in Tongues, Pentecost, Latter Rain, Evidence of Holy Spirit Baptism and a Short History of the Tongues Movement in America and Some Foreign Countries. Portland, OR: The Author, 1926.

Yeomans, Lilian B. Healing From Heaven. St. Louis, Mo: Gospel Publishing House, 1926.

Wesley, John. A Plain Account of Christian Perfection. (New York: G. Lane and P. P. Sandford. 1844 ed., originally 1738.

Washburn, J.F. History and Reminisces of The Holiness Church Work in Southern California and Arizona. Pasadena, CA: Record Press. 1920.

Williams, E. S. Not I, But Christ: Practical Thoughts on Victorious Living. St. Louis, Mo: Gospel Publishing House, 1939.

Woodworth-Etter, Maria. Acts of the Holy Ghost (1912), Das Sind De Zeichen (1943), Holy Ghost Sermons (1918), Life and Experience of Maria $B$. Woodworth (1885), Life and Experience, Including Sermons and Visions, of Mrs. M.B. Woodworth-Etter (1904), Life and Testimony of Mrs. M.B. Woodworth-Etter (1925), Life, Work and Experience of Maria Beulah Woodworth (1894), Marvels and Miracles (1922), Questions and Answers on Divine Healing (1922?), Signs and Wonders (1916), Spirit-Filled Sermons (1921), Trials and Triumphs (1886)

Archival Material: 
(Apostolic Faith Mission Archives at Auckland Park Seminary, Johannesburg, South Africa)

Articles of Association of the Apostolic Faith Mission of South Africa, 1913, and amendments in 1939 and 1948.

The Comforter and Messenger of Hope, Johannesburg, South Africa (19081960) Also published in Afrikaans as Die Trooster en Boodschapper der Hoop.

Personal Diary of John G. Lake 1907-1911.

Personal Diary of P.L. Le Roux, 1890.

The Apostolic Faith Mission Executive Council Minutes, 1908-1938.

The Apostolic Faith Mission Native Worker's Conference Minutes, 1915-1948.

Letter of Christian Catholic Church Certification for Adriana Le Roux, August $5^{\text {th }}$, 1904.

Tracts:

“The Healing Angel” - John G. Lake, Johannesburg, South Africa.

"Not Try But Trust" - John G. Lake, Johannesburg, South Africa.

"The Power of Consecration to Principle" - John G. Lake, Portland Oregon.

Correspondence:

Letter from Overseer Daniel Bryant to P.L. Le Roux, February 14th, 1906.

Letter from Overseer Daniel Bryant to P.L. Le Roux, December 6, 1906.

Letter from John G. Lake to P.L. Le Roux, Date unknown.

Letter from J.H. Creech to Apostolic Faith Mission South Africa, February $23^{\text {rd }}, 1913$.

Letter from Ada White to P.L. Le Roux, November $27^{\text {th }}, 1906$. 
(Du Plessis Archives at Fuller Theological Seminary)

David Du Plessis, "My Experience in Pentecost for 43 Years," Papers of David Du Plessis, 1900-1987 Collection, Box 1, Folder 1, David Du Plessis Archives, David Allan Hubbard Library, Fuller Theological Seminary.

(Sources from the Flower Pentecostal Heritage Center Archives, Springfield, MO. https://ifphc.org/)

Periodicals:

Adult Teachers' Quarterly, Springfield, MO (1927-1939)

Africa's Advocate, Johannesburg, South Africa (July $\left.18^{\text {th }}, 1918\right)$

Altamont Witness, Greenville, SC, (1911-1915)

Apostolic Faith Azusa Street, Los Angeles, CA. (1906-1908)

Apostolic Faith, Portland, OR. (1908-1929)

Bridal Call, Foursquare, Los Angeles, (1921-1924)

Bridegroom's Messenger (1907-1936)

Christ's Ambassadors Herald, Springfield, MO (1926-1939)

Confidence, Sunderland, England (1918-1926)

Full Gospel Missionary Herald, Pretoria, South Africa (1921-1927)

Glad Tidings Herald, New York, NY (1927-1939)

Household of God, Dayton, OH (1906-1910)

Latter Rain Evangel, Detroit, MI (1908-1939)

Leaves of Healing, Zion City, IL (1894-1906)

Midnight Cry, New York, NY (1911-1925)

Pentecostal Evangel, Springfield, MO (1913-1939) 
Pentecostal Herald, Chicago, IL (1915-1923)

The Apostolic Messenger, Winnipeg, Canada. (Feb-March, 1908)

The Christian Evangel, Findley, OH (1914-1919)

The Church of God Evangel, Cleveland, TN, (1910-1995)

The Comforter and Messenger of Hope, Johannesburg, South Africa (October 13 ${ }^{\text {th }}, 1913$ ).

The Macedonian Call, Johannesburg, South Africa (September, 1947)

The Pentecost, Indianapolis, IN (1908-1909), and Kansas City, MO (19091910)

The Pentecostal Testimony, Toronto; Mississauga, ON, Canada (19091912)

The Upper Room, Los Angeles, CA (1908-1911)

Triumphs of Faith, Oakland, CA (1890-1946)

Word and Witness, Malvern, AK (1912-1914), Findlay, OH (1914-1915), and St. Louis, MO (1915-).

Other:

John G. Lake: Letter to Eugene Brooks, June 16 1916.

John G. Lake: Letter to Charles Parham, March 24 ${ }^{\text {th }}, 1927$.

John G. Lake: Letter to Carrie Judd Montgomery, April 22d, 1911.

"Gliggy Bluks off for Wilds of Africa," Indianapolis News, April 1'st, 1908. 
VITA

LINDSEY MAXWELL

Born, Nashville, Tennessee

2004-2007

B.S., History

Tennessee Technological University

Cookeville, Tennessee

2009-2015

Teaching Assistant

Florida International University

Miami, Florida

2012-2016

Doctoral Candidate

Florida International University

Miami, Florida

2015-2016

Dissertation Year Fellow

Florida International University

Miami, Florida

\section{PUBLICATIONS AND PRESENTATIONS}

Lindsey Maxwell, "Sanctifying the South: Holiness, Revival and Black Churches in the South 1830-1860." Presented at the Department of History Graduate Student Association Conference at Florida International University in Miami, FL on March 26, 2011

Lindsey Maxwell, "'Pentecost Both Sides of the Ocean': William Seymour and the Origins of Trans-Atlantic Pentecostalism." Presented at the Department of History Graduate Student Association Conference at Florida International University in Miami, FL on March 31, 2012

Lindsey Maxwell, "A Nation for All Believers: Equality and the Making of South Africa." Review of The Equality of Believers: Protestant Missionaries and the Racial Politics of South Africa by Richard Elphick (Charlottesville: University of Virginia Press, 2012), on H-Net Reviews (May 2013)

Lindsey Maxwell, "The Pneuma Network: William Seymour, Diversity, and Viral Campaigning in Early Pentecostalism." Presented at the American Academy of Religion Conference in San Diego, CA on November 25, 2014 
Lindsey Maxwell, Review of Africa in the American Imagination: Popular Culture, Radicalized Identities, and African Visual Culture by Carol Magee (Jackson, MS: Lindsey Maxwell, University Press of Mississippi, 2012) in The Journal of Popular Culture 47.6 (December 2014): 1333-1335.

Lindsey Maxwell, "Imagining Pentecost: Diversity in the Apostolic Faith, 19061909." Presented at the Department of History Graduate Student Association Conference at Florida International University in Miami, FL on March 27, 2015 